Danmarks Geologiske Undersøgelse.

II. Række. Nr. 65.

\title{
Marint Nedre-Miocæn
}

\section{i Klintinghoved paa Als}

Et Bidrag til Løsning af Aquitanien-Spørgsmaalet

Af

Theodor Sorgenfrei

Med 8 Tavler.

Mit deutscher Zusammenfassung.

I Kommission hos

C. A. Reitzels Forlag

Axel Sandal

København 1940 .

Pris: $6 \mathrm{Kr}$. 
Danmarks Geologiske Undersøgelse.

II. Række. Nr. 65.

\section{Marint Nedre-Miocæn}

\section{i Klintinghoved paa Als}

Et Bidrag til Løsning af Aquitanien-Spørgsmaalet

Af

Theodor Sorgenfrei

Med 8 Tavler.

Mit deutscher Zusammenfassung.

I Kommission hos

C. A. Reitzels Forlag

Axel Sandal

København 1940 . 
Clicheer: Wendt \& Jensen

FR, BAGGES KGL. HOFBOGTRYKKERI KøBENHAVN 


\section{Forord.}

Dette Arbejde er Resultatet af Undersøgelser og Indsamlinger foretaget i Klintinghoved, hvor de paabegyndtes i 1932 og fortsattes i Aarenes Løb i Samarbejde med min Broder Otтo SorgenFREI. For de glade Timer, vi har haft under dette vort Arbejde i Naturen, som er foretaget i vor Fritid, mens vi gik i Skole og i Tiden, der fulgte efter, vil jeg benytte Lejligheden til at sige Tak.

Det er dog dr. phil. H. ØDUM, der i sin Tid gjorde os opmærksom paa Forekomsten ved Klintinghoved, og som i den Tid, jeg har bearbejdet Faunaen, med levende Interesse har fulgt Arbejdet og opildnet mig til at fortsætte mine Undersøgelser; for alt dette skylder jeg al min Tak.

Endvidere skal jeg her benytte Lejligheden til at takke forhenværende Direktør for Danmarks Geologiske Undersøgelse, dr. phil. V. MadSEN, der i 1935 gjorde det økonomisk muligt for mig at foretage en Studierejse til Hamburg og Kiel for at studere de der i Universiteterne opbevarede Samlinger, ved hvilken Lejlighed Prof. dr. KarL GripP viste mig stor Venlighed og ydede mig Hjælp, for hvilket jeg er ham megen Tak skyldig.

Det er mig ogsaa en Glæde at kunne takke Statsgeolog dr. phil. V. Nordmann for al hans Hjælpsomhed ved at stille sin store Viden paa det faglitteræere Omraade til min Raadighed under Studiet af Faunaen og for de Diskussioner, der er ført. Ligeledes skylder jeg Statsgeolog A. Jessen Tak for den Velvilje, hvormed han stillede sit Karteringsmateriale og sine Fotografier til min Raadighed. Professor dr. Hans Frebold takker jeg for hans Hjælp ved Gennemlæsningen af det tyske Manuskript.

Til Slut skal jeg udtrykke min Tak til Direktør dr. phil. H. ØDUM, der har gjort det muligt, at det foreliggende Arbejde, skønt det ikke er Tjenestearbejde, kan optages i Danmarks Geologiske UndersøgelsEs Skrifter. 


\section{Indhold.}

Side

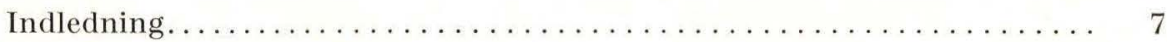

Beskrivelse af de geologiske Forhold .................. 9

De tertiære Jordlag............................ 11

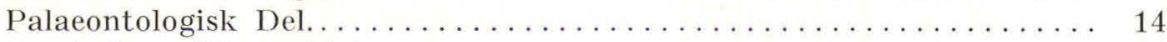

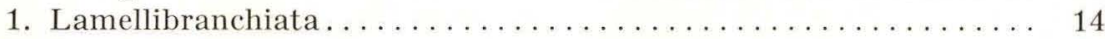

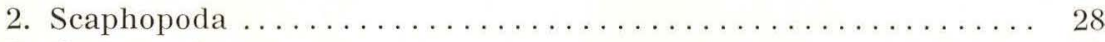

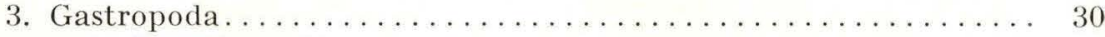

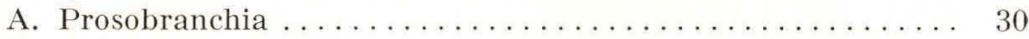

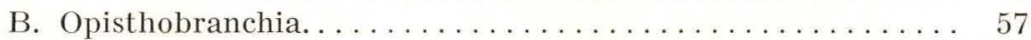

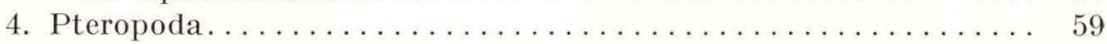

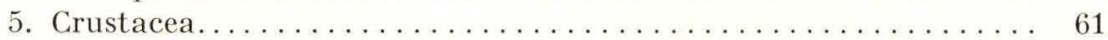

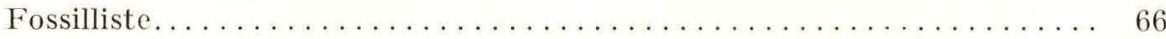

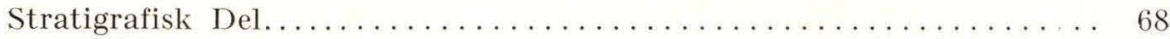

I. Klintinghoved-Glimmerlerets Alder $\ldots \ldots \ldots \ldots \ldots \ldots \ldots \ldots \ldots$

II. Klintinghovedfaunaens Relationer til andre europæiske Miocæn-

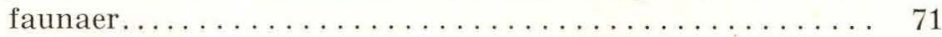

A. Nordsøbækkenet....................... 71

B. Øvre Schlesien, Wienerbækkenet og det ungarske Bækken 73

1. Øvre Schlesien ...................... 73

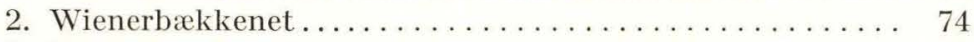

3. Det ungarske Bækken ................. 75

C. Bordeaux-Bækkenet i Vestfrankrig .............. 80

III. Sammenligning med tertiære Faunaer i Nordamerika og Øst-

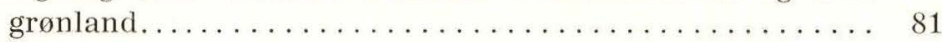

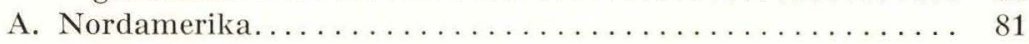

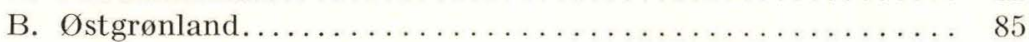

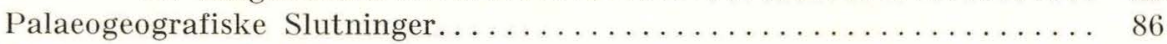

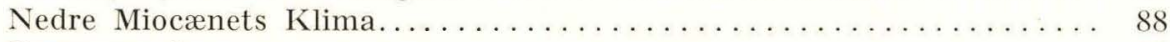

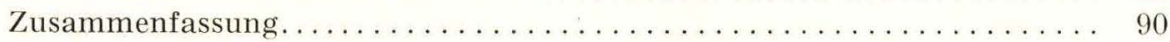

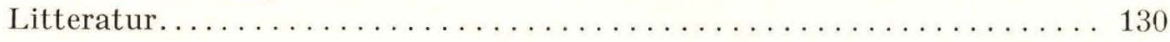




\section{Indledning.}

At der i Klintinghoved optræder »Brunkulsdannelser« bestaaende af Glimmersand og »Alunjord« omtales i Litteraturen for første Gang 1848. Ludwig Meyn, hvem dette skyldes, nævner ganske vist ikke direkte Klintinghoved, men omtaler set Sted ved Kysten Øst for Sønderborg Ladegaard« paa en saadan Maade, at der ikke kan herske Tvivl om, at der er Tale om Klintinghoved, trods den utilstrækkelige Stedsangivelse. Mern meddeler i Afhandlingen: „Geognostische Beobachtungen in den Herzogthümern Schleswig und Holstein«p. 32 følgende: "Bei der Umwandlung eines Theiles der Insel Alsen, welche ich zum Studium des nachher zu charakterisirenden Cyprinenthons unternahm, entdeckte ich vom hohen Uferrande östlich von Langenvorwerk ${ }^{1}$ ) eine Braunkohlenbildung, welche in dem Profil der Küstenwand als Kuppe mit beiderseitig abfallenden Schichten durch den Cyprinenthon emporbricht, etc. Paa Side 33 meddeles endvidere: „Unter räthselhaften Petrefacten und grossen Zweischalern ist nur ein Fusus, eine Natica, ein Buccinum einigermassen generisch zu erkennen, da die Gypsbildung nicht geeignet ist, zarte Charaktere zu conservieren.«

1851 omtaler Meyn atter Tertiæret ved Sønderborg i en kort Bemærkning i Afhandlingen om Lauenburgs og Holstens mellemtertiære Lag. Sammesteds gives en lille Profilskitse af Klinten.

Senere har GotTsche beskæftiget sig med Forekomsten (se GRIPP 382) p. 24); der samledes en Del Fossiler, som bragtes til det geologiske $\mathrm{Mu}$ seum i Hamburg.

I sit banebrydende Arbejde om Nordsøbækkenets nedremiocæne Aflejringer offentliggør GRIPP 1915 en lille Faunaliste, der er udarbejdet paa Grundlag af Materiale indsamlet af Gotwsche, Lærer HANsen, Sønderborg og af GRIPP selv. Listen omfatter følgende Former:

\section{Modiola sericea BronN \\ 2. Nucula laevigata Sowerby \\ 3. Limopsis aurita BRocCHI \\ 4. Tellina fallax Beyrich \\ 5. Thracia ventricosa PHIL. sp.}

1) Sønderborg Ladegaard $\varnothing$ f. Sønderborg.

${ }^{2}$ ) Kursivtallene henviser til Numrene i Litteraturlisten. 
6. Corbula Basteroti HoERnes

\%. Dentalium entale L.

8. Turritella Geinitzi Speyer

9. Bittium spina PARTsch sp.

10. Aporrhais speciosa var. Margerini $\mathrm{DE}$ KonInck

11. Ficula simplex BEYRICH

12. Triton enodis BEYRICH

13. Nassa Schlotheimi BEYRICH

14. Nassa Facki v. Koenen

15. Fusus crispus Borson

16. Pleurotoma turbida Solander

1\%. " trifasciata HoERNES

18. " Duchastelii NYsT

19. " trochlearis HoERNES

20. " Steinvorthi SEMPER

21. Scaphander lignarius L. var Grateloupi MicheLoтTI

Denne særprægede Fauna bevirker, at GRIPP henregner de i Klintinghoved forekommende tertiære Bjergarter til det af ham selv i 1912 opstillede Nedremiocæn, Vierländer Stufe, som det i en Afhandling af samme Forfatter i 1920 opkaldtes efter "Die Vierlande« ved Hamburg, hvor denne Afdeling af Miocænet for første Gang konstateredes i Boringer Aarene før 1912.

Den fra Sønderborg offentliggjorte Faunaliste vakte Opsigt, den gav bl. a. Anledning til at P. Oppenhem (89) fremkom med en Del kritiserende Bemærkninger i Forbindelse med GRIPPs omtalte Afhandling. Som sidste Led i denne Diskussion gav GRIPP derpaa 1920 (38) en supplerende Liste over Fossiler fra Klintinghoved, for en Del indsamlet af ham selv. Af disse var følgende ikke tidligere publicerede:

1. Cardium subturgidum D'ORBIGNY

2. Amiantis islandicoides BRoccHI

3. Xenophora Deshayesii Michelotті

4. Natica helicina BrocchI

5. Cassis megapolitana BeYRICH

6. Murex Deshayesii Nyst

Den kendte Fauna omfatter saaledes paa dette Tidspunkt ialt 27 Arter.

1919 besøgte GRIPP Lokaliteten, uden at det lykkedes ham at finde Fossiler.

I Aaret 1932 gjorde daværende Afdelingsgeolog dr.phil. H. ØDUM min Broder, daværende Mellemskoleelev Otтo Sorgenfrei og mig opmærksom paa, at der i det sorte Glimmerler i sin Tid var fundet de alle- 
rede omtalte interessante Fossiler. Min Broder og jeg begyndte derefter samme Aar en systematisk Undersøgelse af Glimmerleret og -sandet uden dog at have synderlig Held med os, idet vi trods ihærdige Eftersøgninger og Gravninger overhovedet ikke fandt et eneste Fossil. I 1933 lykkedes det imidlertid ved et rent Tilfælde min Broder at finde en enkelt Skal; dette Fund viste Vej til talrige nye, der skulde gøres i de følgende Aar.

Stedet besøgtes derefter jævnligt, sidste Gang 1937; der foretoges Udgravninger og Eftersøgninger, der resulterede i en Samling af en ejendommelig Faunas smukt bevarede Skaller, som her skal beskrives og diskuteres $\left.^{1}\right)$.

\section{Beskrivelse af de geologiske Forhold.}

Klintinghoved er beliggende ca. $3,5 \mathrm{~km}$ SØ f. Sønderborg Slot. Den indtil $13 \mathrm{~m}$ høje Kystklint, der vender ud mod Sønderborg Bugt, er for Tiden udsat for stærk Erosion af Havet; der er derfor i Tidens Løb fremkommet et smukt Profil i Kysten (Tavle II og III).

20. Januar 1935 foretoges en Opmaaling af Profilet. Resultaterne heraf er gengivet paa Profiltegningen Tavle I.

Det fremgaar klart af Profiltegningen, at det tertiære Glimmerler og -sand $\mathrm{i}$ den vestlige Del af Klinten mellem Punkt 0 og 18 findes som Flage i Kvartæret, da det ligger indlejret i Moræneler. Fra Punkt 13-14 foretoges en Udgravning i Strandkanten, idet der paa dette Sted i Glimmerleret fandtes særlig mange Fossiler. Under Glimmerleret fandtes her Moræneler.

Fra Punkt 28 til 87 følger dernæst en større Serie tertiære Jordlag, der ved Forkastninger deles i tre Hovedpartier. Det vestlige af disse strækker sig fra Punkt 28 til 55. Som hos den først omtalte Flage iagttages ogsaa her under Tertiæret Moræneler. Denne Del af Flagen staar højst sandsynlig under Strandlinien i Forbindelse med den før omtalte Vest herfor. Den Ø f. Punkt 55 beliggende Del af Flagen deles ved en Forkastning ved Punkt 79 i to Dele, der er forskudt omtrent $1 \mathrm{~m}$ i Forhold til hinanden. De underliggende Lag kan for hele denne Del af Flagen ikke iagttages men bestaar højst sandsynlig af kvartære Aflejringer. Serien overlejres af Moræneler og Diluvialsand.

I den østlige Del af Flagen, mellem Punkt 79 og 85 ligger Glimmerlerets Lag omtrent vandrette for derefter mellem 85 og 87 at være mere

1) Ved et Besøg paa Stedet d. 13. Sept. 1940 var den fossilførende Del af Flagen faldet som Offer for Havets Erosion. 
eller mindre forstyrrede samtidig med, at Lagene bøjes for til sidst ved Punkt 87 at staa næsten lodrette.

Vender vi os til Tolkningen af Profilet, da er det ifølge hele Klintens Opbygning indlysende, at vi har at gøre med et løsrevet Parti af den tertiære Undergrund. Iøvrigt skal jeg ikke her indlade mig paa en detailleret Tolkning af Istektoniken, fordi jeg har anset det for at ligge uden for dette Arbejdes Rammer. Der skal dog ganske kort gøres Rede for en Del Overvejelser, der kan have Betydning i denne Sammenhæng.

Som allerede nævnt, vil jeg anse det for sandsynligt, at Flagen mellem Punkterne 0 og 18 under Strandlinien staar i Forbindelse med den vestlige Del af den næste Flage, der begynder omkring Punkt 28,5. Der synes endvidere at være en vis Overensstemmelse mellem Partiet 28,5 -55 og Serien fra Punkt 60 til 87; i begge Afdelinger finder vi nederst Glimmerler, der ganske vist mellem Punkterne $40 \mathrm{og} 55 \mathrm{~m}$ er lidt sandet, derover Glimmersand og øverst atter Glimmerler. De to Dele skilles mellem Punkterne 55 og 60 ved et Parti af mere uregelmæssigt lejret og forstyrret Glimmerler. Den fremdragne Lighed mellem de to Afdelinger tyder paa, at der er Tale om Dele af en oprindelig sammenhængende Flage.

Den østligste Del af Flagen mellem Punkterne 79 og $87 \mathrm{~m}$ skilles ved Forkastningen ved $79 \mathrm{~m}$ fra det Vest herfor liggende Parti; Overensstemmelsen og den oprindelige Sammenhæng mellem disse to Dele er dog klar og eentydig. Det maa anses for givet, at den omtalte Forkastning er fremkommet under Isens Transport af Flagen og skyldes den Omstændighed, at hele Sedimentflagen paa det Tidspunkt, den transporteredes, som Følge af sin frosne Tilstand opførte sig som en sammenhængende Bjergart. En Forkastning kunde saaledes nemt forekomme, uden at den oprindelige Lagfølge forstyrredes i særlig høj Grad.

Forudsat at Lagene mellem Punkt 28,5 og 55 til at begynde med udgjorde et Hele sammen med den øvrige $\varnothing$ herfor liggende Del af Flagen, kan den senere opstaaede Adskillelse ved $60 \mathrm{~m}$ Punktet tænkes fremkommet ved en Forkastning af lignende Art som ved Punkt 79, kun er de to saaledes adskilte Dele fjærnet længere fra hinanden. Mellemrummet er derefter udfyldt ved nedskredne Dele af Glimmerleret.

Det vilde have været til Støtte for den fremførte Hypothese, om man ved Fossiler havde været i Stand til at paavise Overensstemmelser mellem de forskellige Afdelingers tilsvarende Lag. Da der imidlertid ved de af min Broder og mig foretagne Indsamlinger og Gravninger kun er fundet Fossiler i Glimmerleret mellem Punkterne 0 og 20, lader dette sig ikke gøre.

Af overordentlig stor Værdi vilde det være, om man var i Stand til 
at fastslaa de her omtalte Tertiærbjergarters oprindelige Aflejringssted. Med Sikkerhed at fastslaa dette er ikke muligt, vi maa nøjes med en omtrentlig Bestemmelse.

En Ting, der taler for, at Flagerne ikke er blevet transporteret et alt for langt Stykke Vej af Isen, er den, at Lagene i ret høj Grad synes at have bevaret deres oprindelige Textur. Selv om man maa antage, at Lagene maa have været frosne og som Følge heraf maa have opført sig som en sammenhængende Bjergart, maa man huske, at de samtidig paa en vis Maade maa betragtes som en Del af den Indlandsis, der fragtede dem, og derfor ogsaa har været i Besiddelse af en Del af Isens Egenskaber, bl. a. dens Plasticitet. Udsat for lange Tiders Isbevægelse maa man derfor vente, at en Lagserie af denne Art paa en vis Maade valses ud til lange tynde Partier uden ret mange Spor af den oprindelige Lagdeling. Disse Overvejelser faar mig da til at antage, at det oprindelige Aflejringssted ligger ikke alt for fjernt fra Tertiærflagernes nuværende Plads (sammenlign Miocænet ved Langbrogaard (74)).

Ved Besvarelsen af Spørgsmaalet, i hvilken Retning Indlandsisens Transport er foregaaet, er det vigtigt at lægge Mærke til de stejlt stillede Lag ved Punkt 87, der bøjes saaledes, at de mellem Punkterne $85 \mathrm{og}$ 80 er næsten vandrette. Dette Forhold berettiger efter min Mening en Antagelse af en Isbevægelse, der omtrent har Retning fra Øst til Vest eller mere ØsØ-VNV. Tertiærets oprindelige Aflejringssted maa derfor søges Øst eller Sydøst for Klintinghoved. Den af GoтTsche (33, p. 3) omtalte Forekomst af Glimmerler ved Kegnæs Fyr staar i god Samklang hermed. For dennes Vedkommende maa Lejringsforholdene siges at være uopklarede; muligvis drejer det sig om en Forekomst af lignende Art som ved Klintinghoved.

Den antagne Bevægelsesretning falder sammen med, hvad man i Almindelighed antager for at være Bevægelsesretningen for Vemmingbund Gletscheren, der bl. a. har bevirket Opskydningen af Vemmingbund Randmoræenen og desuden, hvad der kan være ganske interessant i denne Sammenhæng, en anden Serie af marine Lag, de interglaciale Eemlag i Stensigmose Klint paa Broagerland, $6 \mathrm{~km}$ i lige Linie VSV f. Klintinghoved.

\section{De tertiære Jordlag.}

Under Beskrivelsen af Profilet vil man ikke have undgaaet at bemærke, at der baade er Tale om Glimmerler og Glimmersand. Paa Profilskitsen er der saa nøjagtigt som muligt forsøgt en Gengivelse af Sedimenter- 
nes Udbredelse i Klinten, selvom det paa visse Steder er vanskeligt som Følge af, at Sand og Ler veksellejrer i tynde Lag.

Nogen petrografisk Undersøgelse af de tertiære Bjergarter er ikke foretaget i denne Forbindelse, dog har HeLge GRY 1935 offentliggjort Resultaterne af en saadan Undersøgelse af Glimmerleret i Klintinghoved i Tilslutning til den petrografiske Analyse af Boreprøverne fra Langbrogaard (74). Efter Helge GRY staar Bjergarterne fra de øverste tertiære Lag i disse Boringer og Glimmerleret i Klintinghoved hinanden nær, baade hvad angaar Hovedkornstørrelse og Mineralindhold, selvom den af ham undersøgte Prøve fra Klintinghoved har et mere sandet Præg end Leret fra Boringerne. Efter HELge GRY ligger saaledes Hovedkornstørrelsen for de sandede Partier omkring $0,1 \mathrm{~mm}$, for de lerede omkring 0,05 mm. M. H. t. Mineralindholdet bestaar Sandet hovedsagelig af Kvarts, dertil betydelige Mængder Glimmer, nemlig Muskovit og lidt grøn Glimmer. Ved Kornstørrelsens Aftagen tiltager Glimmernes Mængde i Forhold til Kvartsens. Foruden de anførte Mineraler findes to kemisk nydannede Mineraler, smaa Svovlkiskonkretioner $(0,02-0,03 \mathrm{~mm})$ og Glaukonitkorn $\left.{ }^{1}\right)$.

Hertil skal tilføjes, at Glimmerlerets Farve ved en almindelig Betragtning synes næsten sort, enkelte Partier kan være mere graalige. I jordfugtig Tilstand er det ret mørkt med et grønligt eller brunligt Skær, der forsvinder ved Tørring. Glimmersandet er meget lyst, stedvis næsten hvidt. I visse Zoner forekommer udskilt Jern, og Sandet synes da mere gulligt eller rødligt.

Til Omtalen af Mineralindholdet er endvidere at bemærke, at der i visse Partier af Glimmerleret, især mellem Punkterne 60 og 80, i udstrakt Grad findes Gipskrystaller, der kan opnaa den ganske betydelige Størrelse af flere $\mathrm{cm}$. Ligesom Pyriten og Glaukoniten maa Gipsen regnes til de nydannede Mineraler, selvom den maa anses for at være dannet, efter at Leret udsattes for Forvitringen, og saaledes tilhører en anden Cyklus end de to føromtalte. Iøvrigt omtales Gipsen allerede af MEYN ( $\left.y^{\prime} /\right)$.

De mellem Punkt 0 og 20 i Glimmerleret fundne marine Fossiler beviser dets marine Oprindelse. (Det samme skal efter Helge Gry Indholdet af Glaukonit vise). Naar der ikke andre Steder i Glimmerleret er fundet Fossiler, kan det forklares ved, at der i disse Partier ikke er aflejret noget Fossil; men langt rimeligere er det at antage, at de ogsaa fandtes her, men paa et tidligere Tidspunkt faldt som Offer for Pyritens

1) Svovlkisens Dannelse er en diagenetisk Proces, der paabegyndes umiddelbart efter Aflejringer af Sedimentet; Glaukoniten nydannes derimod i Tilknytning til selve Sedimentationen og maa derfor nærmest betragtes som en autochton eller ankiautochton Bestanddel af Sedimentet, (jf. Helge Gry: Petrology of the Paleocene Sedimentary Rocks of Denmark, p. $155 \mathrm{og} 161$ ff. D. G. U. II. Række Nr. 61. København 1935). 
Svovlsyreforvitring. Herom vidner Gipskrystallerne, der kan iagttages paa mange forvitrede Fossiler fra den vestlige fossilførende Flage. De mange Gipskrystaller i Glimmerleret mellem Punkterne 60 og 80 tyder endvidere paa, at Svovlsyreforvitringen her er ført til Ende fremskyndet ved de gode Gennemstrømningsmuligheder for Nedbøren gennem det overliggende Smeltevandssand og det underliggende Glimmersand; derfor finder vi her ingen Fossiler.

Ogsaa Glimmersandet er marint. Ganske vist er der ikke bevaret Skaller her, idet de er opløste; men stedvis, hvor Jernforbindelser har sammenkittet Sandet, er det muligt at iagttage Aftrykkene efter Fossiler. Nogen nøjagtig Bestemmelse kan dog, hvad rimeligt er, kun foretages i de færreste Tilfælde. Følgende kunde bestemmes:

1. Nucula sp. (cfr. hanseata KaUtsky)

2. Yoldia sp. (cfr. glaberrima MüNsт.)

3. Cardium sp. (cfr. subturgidum D'ORBIGNY)

4. Tellina sp. (cfr. fallax BEYR.)

5. Mactra sp.

6. Thracia sp. (cfr. ventricosa Pншь.)

\%. Chenopus sp. (cfr. speciosus Schцотн.)

8. Cassis sp. (cfr. Rondeletii Basterot)

9. Tritonium sp.

Nogen sikker Aldersbestemmelse af Glimmersandet efter de fundne Fossiler er ikke mulig. For disses Vedkommende drejer det sig, saa vidt det kan ses, med Undtagelse af Mactra sp. om Fossiler, som ogsaa er fundet i Glimmerleret. Som Følge af dette og af den nære Tilknytning, der ved en almindelig Betragtning synes at bestaa mellem de to Bjergarter, maa det anses for sandsynligt, at de i Tid staar hinanden meget nær; i al Fald kan de ikke skilles faunistisk. 


\title{
Palaeontologisk Del.
}

\author{
1. Lamellibranchiata. \\ Familie: Pectinidae La m k. (1801). \\ Genus: Lissochlamys Sacco (1897). \\ 1. Lissochlamys cir. Gérardi $\mathrm{N}$ y $\mathrm{t}$ \\ Tavle IV. Fig. 1.
}

1845. Pecten Gérardi Nyst; Coqu. et Polyp. foss. de la Belgique; p. 300, t. VII, f. 11.

1850. " " Wood; Crag Moll. II; p. 24, t. 5, f. 5.

1907. "sp.? RAvN; p. 48.

1925. Lissochlamys cf. Gérardi Nyst; Kautsky; Hemmoor; p. 12.

Til denne Art henføres en lille Højreskal, der er $3 \mathrm{~mm}$ høj og $3 \mathrm{~mm}$ lang. Den synes selv under Loupe glat med svage Tilvækststriber. Under forreste Ore findes et Byssusindsnit. Skallen er ubetydelig skæv skraat nedad-fremefter.

Den af RAvN omtalte Pecten kan muligvis henføres til samme Art.

Miocæn: Nordtyskland (n. m.ø.) $)^{1}$ ), Holland, Belgien (Anversien).

Pliocæn: England, Belgien.

Genus: Pecten Lamk. (1799).

\section{Pecten $\mathrm{sp}$.}

Der er fundet et Brudstykke af en Skal, der viser bølgeformede Radialribber. I Fordybningerne mellem Ribberne er antydet en Række svage Knuder.

\section{Familie: Mytilidae Guv. (1817) em. \\ Genus: Arcoperna Con rad (1865).}

\section{Arcoperna sericea Bron $n$}

1831. Modiola sericea Bronn; Italiens Tertiär-Gebilde; p. 112.

1843. Mytilus sericeus " Nyst; Coqu. et Polyp. foss. de la Belgique; p. 271, t. XXI, f. 2.

\footnotetext{
1) $\mathrm{n.}=$ nedre, $\mathrm{m} .=$ mellem, $ø .=$ ovre.
} 
1850. Modiola sericea Bronn; Wood; Crag Moll. II; p. 61, t. VIII, f. 3.

$1870 . "$ " " Hoernnes; Wienerb. II; p. 346, t. 45 , f. 1.

1874. " "Wood; Crag Moll. Supplem. p. 213.

1916. " " " (non Phil.); Nørregandi p. 10, t 1, f. 4.

1925. Arcoperna " " Kautsky; Hemmoor; p. 15.

2 tveskallede Exemplarer, hvoraf den ene er en Stenkærne med Rester af den tynde Skal. Det andet Exemplar er en Ungdomsform med en Højde af 2,8 $\mathrm{mm}$, begge Skaller bevaret.

Skallens Indre er perlemorskinnende og dens Overflade er forsynet med talrige fine Radialstriber, der skæres af den lidt kraftigere Tilvækstskulptur.

Dimensionerne for de to Exemplarer er følgende:

$\begin{array}{ccc}\text { Højde } & \text { Bredde } & \text { Tykkelse } \\ 22,8 \mathrm{~mm} & 16,8 \mathrm{~mm} & 13,2 \mathrm{~mm} \\ 2,8 》 & 1,9 » & 1,5 》\end{array}$

De svarer godt i Forholdene mellem Dimensionerne til de af Nyst, Hoernes og Norregand beskrevne Skaller.

Miocæn: Danmark, Nordtyskland (n. m.) Wiener Bækken (2 Medit.) og Italien (Helvétien)

Pliocæn: England, Belgien, Italien.

\section{Familie: Nuculidae D'Or big n y (1844). \\ Genus: Nucula Lamk. (1799).}

\section{Nucula hanseata Ka utsky}

Tavle IV. Fig. 2, 3.

1925. Nucula hanseata Kautsky; Hemmoor; p. 22, t. 2, f. 10.

1937. " " Sorgenfrei; Some Rem. etc.

15 Exemplarer, hvor begge Skaller er bevaret, desuden talrige Brudstykker. Skallerne er velbevarede, men sidder fast paa Stenkærner. En enkelt Skal har dog kunnet præpareres, saaledes at dens Indre kan iagttages.

Skallen er temmelig stærkt hvælvet og stærkt uligesidet, saaledes at Dorsalranden foran den opistogyre Hvirvel er omtrent tre Gange Længden af den bagved Hvirvlen liggende Del af Dorsalranden. Dorsalranden danner ved Hvirvelen en Vinkel paa ca. $115^{\circ}$.

Forreste Dorsalrand danner en tydelig Vinkel med Skallens Forrand, der atter i en temmelig stærk Bue gaar over i Ventralranden. Denne sidste danner en mere svag Bue til omtrent lodret under Hvirvelen, hvor der findes et svagt Knæk, der ogsaa viser sig i Tilvækstliniernes Forløb, for derefter i omtrent lige Linie at fortsætte til den mødes med bageste Dorsalrand under en tydelig Vinkel paa ca. $120^{\circ}$. 
Foran Hvirvlerne afgrænses paa hver Skal ved en Bue, fremkommet ved svage Knæk i Tilvækstlinierne paa dette Sted, en tydelig markeret Pseudolunula. Denne markeres i de fleste Tilfælde yderligere ved overordentlig smaa Porer i Skallens Overflade langs med den omtalte Bue. Denne Porerække maa forklares fremkommet ved Perforering af Skallen ud for Tandgruberne (Sorgenfrei 1937). Uden om Pseudolunula gaar paa hver Skal en svag, men tydelig Depression fra Hvirvelen til Forranden af Skallen.

Bagved Hvirvlerne findes en til Pseudolunula svarende Area, der er nedsænket i Forhold til Skallens øvrige Overflade. I Furen lige indenfor den fremstaaende Fold, der begrænser Area, findes tilsvarende Porer, som beskrevet under Pseudolunula. Baade for denne sidste og for Areas Vedkommende gælder, at Porerne er tydeligst udviklet nærmest Hvirvelen. Det under Beskrivelsen af Skallens Omrids nævnte lige Stykke af Ventralrandens bageste Del markerer et Parti af Skallen omkring Area, der er et Analogon til den svage Depression omkring Pseudolunula.

Skallens Tilvækstlinier staar ofte i relativt stærkt Relief. Skallen prydes af lysere og mørkere Farvebaand.

En defekt Højreskal kunde præpareres, saaledes at det Indre af Skallen har kunnet iagttages. Ventralranden er brækket af, og Partiet ved bageste Lukkemuskel mangler ligeledes. Paa andre Skalfragmenter kan det ses, at Randen er glat indvendig.

I Hængselet foran Hvirvelen findes 21 kølede, spidse Tænder. Den bageste Del af Hængselet bag Hvirvelen er brækket af, og Tændernes Antal kan saaledes ikke opgives. Area ligamentis strækker sig fra Hvirvelen til Tand Nr. 10 gaaende ud fra Hvirvelen.

Fodmusklernes Aftryk kan tydeligt studeres. Der skal her gøres Rede for dem.

Paa Skallens Ryg findes et smalt Muskelaftryk $\left.(1)^{1}\right)$, der strækker sig fra Forenden af area ligamentis med lateral Retning. Foran dette lidt nærmere Ventralranden findes et bredere mediant Fodmuskelaftryk (musc. retract. pedis posterior) (2) under dette et mindre rundt Aftryk (3) samt et punktformet centralt Aftryk (4) ( $m$. elevator pedis); lidt foran disse ligger $\mathrm{i}$ en Bue, der naar hen til forreste Lukkemuskelaftryk 5 punktformede Fodmuskelaftryk (m. m. retractores et protractores pedis anterior (5-9)).

Miocæn: Nordtyskland (m.) og Belgien (Boldérien).

\section{Nucula nucleus L. var. Hanleyi W in $\mathrm{ck}$ w o $\mathrm{th}$.}

1925. Nucula nucleus L. Kautsky; Hemmoor; p. 23, t. 2, f. 11-12.

1935. " " var. hanleyi Winckworth; Schenck; Proc. of the Mal. Soc. Vol. XXI, Part IV. March 1935, p. 258.

3 tveskallede Exemplarer, 3 Venstreskaller og een Højreskal.

\footnotetext{
1) Tallene i Parentes henviser til Numrene paa Muskelaftrykkene paa Tavle IV, Fig. 3.
} 
Exemplarerne er i Overensstemmelse med Afbildningerne hos KaUTSKY ; m. H. t. Skulpturen er at bemærke, at Radialskulpturen ikke er saa fremtrædende som Tilvækstskulpturen.

Efter Schenck staar $N$. nucleus L. var. Hanleyi meget nær ved $N$. nucleus L., den adskiller sig fra denne især ved spidsere Hængselvinkel og "mørke« Radialstriber. Skallerne fra Klintinghoved har et mere trekantet Omrids end det hos Schenck skitserede.

Afbildninger viser, at de af GLENN omtalte Skaller af $N$. proxima SAy. fra Marylands Miocæn (Maryland Mioc. p. 398, t. CVIII, f. 5-6) staar N. nucleus L. var. Hanleyi nær; det samme gælder øjensynlig ogsaa N. Benoisti Cossm. et Peyrot (Act. Linn. LXVI, p. 211, t. V, f. 34 -37.). Disse to Former er saaledes muligvis identiske med denne.

Miocæn: Nordtyskland (m.).

\author{
Familie: Ledidae Adams (1858). \\ Genus: Leda Schum. (1817). \\ Subgenus: (Jupiteria) Bellardi (1875).
}

\title{
6. Leda (Jupiteria) pygmaea $M$ ünst.
}

(1836. Nucula tenuis Philippi; Enum. Mol. Siciliae I; p. 65, t. 5, f. 9.)

1837. Leda pygmaea Mü. Goldfuss; II; p. 157, t. 125, f. 17.

(1843. Nucula Philippiana Nyst; Coqu. et Polyp. foss. de la Belgique; p. 224. t. 17. f. 5.)

1861. Leda pygmaea Mü. Woon; Crag Moll. II; p. 95, t. 10, f. 11.

1884. " " Speyer - v. Koenen; Cassel; t. 17, f. 4 - 5.

1892.? " tenuis Phil. Lehmann; Mioc. von Dingden I; p. 220.

1907. Portlandia pygmaea Mü. sp. Ravn; p. 260, t. 1, fig 9-10.

$1913 . "$ " " Harder; p. 52, t. 3, f. 15.

1914. Leda (Portlandia) pygmaea Mü. sp. Gripp; Itzehoe, p. 6.

1916. Portlandia " " Nørregatard; p. 12.

1925. Leda (Jupiteria) " " KaUtsky; Hemmoor; p. 24.

Af denne Art foreligger et toskallet Exemplar (Længde 3,0 mm, Højde 2,2 mm, Bredde 1,6 m) en Venstre- og en Højreskal.

Der har i Litteraturen været en Del Diskussion om, hvorvidt de omtalte $N$. tenuis og $N$. Philippiana er identiske med denne Art eller ej. Uden at indlade sig paa nogen Begrundelse stiller KAUTSKY dem under samme Navn. P. Gr. a. manglende Sammenligningsmateriale kan der ikke her bidrages væsentligt til Belysning af Forholdene; for en Fuldstændigheds Skyld er de dog opført i Synonymlisten.

Oligocæn: Danmark (ø.), Nordtyskland (m. ø.).

Miocæn: Danmark, Nordtyskland (n. m. ø.).

Pliocæn: England, Belgien. 


\section{Genus: Yoldia Möl1er (1842).}

\section{Yoldia glaberrima $M$ ü nst.}

Tavle IV, Fig. 4.

1837. Nucula glaberrima Münst. Goldf. Petref. Germ. II, p. 157, t.125, f. 14.

1861. Leda " " Semper; Paläont. Unters. p. 145.

1874. Nuculana " "SPeyer-v. Koenen; Cassel; t. 17, f. 1-2.

1884. "(Portlandia)" " Мøвсн; Forsteninger i Tertiærlag. p. 278.

1907. Yoldia " "sp. Ravn; p. 261, t. 1 , f. 13.

$1913 . "$ " " Harder; p. 52, t. III, f. 16.

1914. " " " GRIPP; Itzehoe, p. 6.

1916. " " " Nørregatrd; p. 12.

1925. " " " KAUTSKY; Hemmoor; p. 24.

15 mere el. mindre defekte Stykker samt 4 Exemplarer, hvor begge Skaller er bevaret.

En beskadiget Venstreskal er præpareret ud saaledes, at Skallens Indre har kunnet undersøges. Der bør i denne Sammenhæng særlig nævnes, at der indvendig i Skallen findes en svag Fold eller en rendeformet Fordybning gaaende fra Hvirvelen lidt fremefter til Skallens Ventralrand. Dette Forhold kan ogsaa iagttages hos Yoldia laevis SAY. fra Marylands Miocæn (Maryland Mioc. p. 397, t. CVIII, f. 3-4), hvis nære Slægtskab med $Y$.glaberrima er omtalt af KaUtsky.

Jeg er tilbøjelig til at anse disse to Arter for at være identiske, da de $\mathrm{i}$ alle Forhold synes at stemme overens.

Oligocæn: Danmark (ø.), Nordtyskland (ø.).

Miocæn: Danmark (m.), Nordtyskland (n. m.) Holland.

\section{Familie: Arcidae F1eming (1828). \\ Genus: Arca Linné (1758).}

\section{Arca sp. cfr. decussata $\mathrm{N}$ ys t et $\mathrm{W}$ e st.}

1845. Arca decussata Nyst et West. Nyst; Coqu. et Polyp. foss. de la Belgique; p. 358, t. VI, f. 11.

1867. " " v. Koenen; Mitteloligocän, p. 90.

Der er fundet et Fragment af en lille Venstreskal tilhørende en Arca, Partiet omkring Hængselet er bevaret, Brudstykket maaler 11/2 mm paa den længste Led.

Skulpturen minder en Del om Arca decussata, men paa Grund af den ufuldstændige Bevaringstilstand og Fragmentets Lidenhed kan en sikker Bestemmelse ikke foretages.

A. decussata er fundet i Nordtyskland og Belgiens Oligocæn (n. m. ø?). 
Familie: Limopsidae Da 11 (1895).

Genus: Limopsis Sassi (1827).

\section{Limopsis aurita B roc ch i}

Tavle IV, Fig. $5,6$.

1863. Limopsis aurita Brocchi; Jeffreys II; p. 161, t. 30, f. 1.

1892. " " " LehmanN I; p. 212.

1898. " " SAcco XXVI; p. 39, t. IX, f. 23-30.

1907. " "sp. Ravn; p. 265.

1907. "Goldfussi (non Nyst) Ravn; p. 264.

1913. " aurita Brocchi var. parva Harder; p. 53, t. 3, f. 19-21.

1914. " " sp. Gripp; Itzehoe; p. 7.

1925. " " var. minuta KaUtsky; Hemmoor; p. 19, t. 2, f. $4-5$.

Af denne Art findes talrige Skaller, idet den vel nok er den hyppigste Lamellibranchiat i Glimmerleret.

Der er givet en god Beskrivelse af Skallens Skulptur hos P. HARder (t. III, f. 19 c.). Da der anføres, at Skallerne fra Aarhus især adskiller sig fra de miocæne ved at være væsentlig mindre og ved at besidde en mindre udpræget Skævhed end disse, skal der her i Lighed med HaRDERs Maalinger paa Skallerne fra Aarhus gives en »Skævhedskvotient« for Skallerne fra Klintinghoved.

Skævhedskvotienten er udtrykt ved Forholdet mellem Skallens længste og korteste Udstrækning, begge i Dorsoventralplanet. Skævheden fremkommer ved, at Forenden er stærkere udviklet end Bagenden.

Ved Maalingen af Skallen faas Udtryk for to Linier i Skallens Medianplan, der omtrent staar vinkelret paa hinanden. Maalene for den længste og korteste Akse er angivet i mm. Skævhedskvotienten fremkommer som nævnt ovenfor som Forholdet mellem længste og korteste Akse.

\begin{tabular}{l|c|c|c|c|c|c|c|c|c}
\hline \hline Længste Akse & 1,70 & 2,8 & 3,3 & 4,6 & 5,0 & 5,0 & 5,4 & 5,6 & 6,5 \\
Korteste Akse & 1,65 & 2,7 & 3,0 & 4,3 & 4,5 & 4,6 & 5,0 & 4,9 & 5,8 \\
\hline Skævhedskvotient & 1,03 & 1,04 & 1,10 & 1,07 & 1,11 & 1,09 & 1,08 & 1,14 & 1,12 \\
\hline
\end{tabular}

\begin{tabular}{l|c|c|c|c|c|c|c|c|c}
\hline \hline Længste Akse & 7,0 & 7,6 & 7,7 & 8,6 & 9,3 & 9,4 & 9,8 & 10,0 & 11 \\
Korteste Akse & 6,1 & 6,7 & 6,7 & 7,4 & 8,3 & 8,0 & 8,5 & 8,2 & 9 \\
\hline Skævhedskvotient & 1,13 & 1,13 & 1,15 & 1,16 & 1,12 & 1,18 & 1,15 & 1,22 & 1,22 \\
\hline
\end{tabular}

HARDer anfører for Exemplarer fra Aarhus en gennemsnitlig Skævhedskvotient paa 1,09. Det største hos HARDER afbildede Exemplar har en Højde paa 7,4 mm, Skævhedskvotienten udregnet efter t. III, f. 19 
er 1,10. I Modsætning hertil anføres for Skaller fra Esbjerg en Kvotient paa 1,13 .

De for Skallerne fra Klintinghoved anførte Skævhedskvotienter illustrerer imidlertid to væsentlige Forhold. For det første findes temmelig store Variationer i Skævhed for Skaller af samme Størrelsesorden, og for det andet har Skævheden en Tendens til at blive større med Skallens Vækst, hvilket maa synes meget naturligt.

Det vil ses, at HARDERS Skævhedskvotient sammen med de tilsvarende Skallers Størrelsesorden udmærket harmonerer med den anførte Række fra Klintinghoved. Det vil saaledes være tvivlsomt, om Varieteten bør opretholdes. Den af Kautsk y opstillede Varietet er uden Tvivl identisk med den af HARDER opstillede og gaar af Prioritets Hensyn ind under denne, saafremt den opretholdes, hvilket som nævnt maa fraraades.

Olig ocæn: Danmark (ø.).

Miocæn: Danmark (m.ø.) Nordtyskland (n. m.ø.) Belgien (Anversien) Vestfrankrig (Tortonien) og Italien (Helvétien, Tortonien).

Pliocæn: England, Belgien, Italien.

\section{Familie: Astartidae D'Or big ny (1845). \\ Genus: Astarte Sowerby (1816).}

10. Astarte concentrica Gold f.

Tavle IV, Fig. 8.

1834/40. Astarte concentrica GoldF. II; p. 195, t. 135, f. 7 .

1868. " "

1884. " " "

1892. " " " LEHMANN I, p. 226, pars.

1907. 》 》 RavN; p. 64, t. 1, f. 23 ? pars.

1914. " " " " "

1916. "

1925. 》 》 KAutsky; Hemmoor; p. 25, t. 2, f. 17.

Til denne Art henregnes en Højreskal med følgende Maal: Højde 5,7 mm, Længde 4,8 mm, Bredde 1,7 mm. Den svarer godt til Afbildningen hos Kautsky, men dens Dorsalrand danner dog en lidt større Vinkel.

KaUtsky henregner Ravns A. concentrica til var. gracilis Münster, der har tættere staaende Ribber. Da RAvN meddeler, at A. concentrica „i Almindelighed har tættere staaende Ribber end A. Kickxi NysT«, tør det vel formodes, at der blandt Ravns Materiale findes Former med grovere Ribber, der maa henregnes til A. concentrica GoLDF.

Oligocæn: Danmark (ø.), Nordtyskland (ø.).

Miocæn: Danmark (m.), Nordtyskland (n. m.), Holland. 
11. Astarte pygmaea v. $M$ ü nst. sp.

\begin{tabular}{|c|c|c|c|c|c|}
\hline 37. & tarte & pygmaea & v. & ÜNST. & $\begin{array}{l}\text { Goldfuss; Petref. Germ. II, p. } 195 \text {, t. } \\
\text { 135, f. } 5 \text {. }\end{array}$ \\
\hline 1884. & 》) & " & " & $"$ & $\begin{array}{l}\text { Speyer - v. Koenen; Cassel; t. } 15 \text {, f. } \\
3-4 .\end{array}$ \\
\hline 884. & " & gracilis & " & " & Speyer - v. Koenen; ibid. t. 15, f. $1-2$. \\
\hline 1893. & ") & pygmaea & $"$ & $"$ & $\begin{array}{l}\text { v. Koenen Unter Oligocän, V; p. } 1224 \text {, } \\
\text { t. } 86 \text { f. } 6-8 \text {. }\end{array}$ \\
\hline & » & " & $"$ & " & RAvN; p. 270. \\
\hline & ") & $"$ & " & $"$ & var. HaRder; p. 57 , t. IV, f. 18. \\
\hline
\end{tabular}

En Højreskal med beskadiget Hængsel, Bagranden ligeledes lidt beskadiget.

Skallen passer godt til Ravys Beskrivelse. Ventralranden er krenuleret. Højde og Længde 2,8 mm, Bredde 0,8 $\mathrm{mm}$.

Oligocæn: Danmark (ø.), Nordtyskland (n. m. ø.).

\section{Familie: Isocardiidae Gray (1840). \\ Genus: Isocardia (K 1 ein 1753) La marck (1799).}

12. Isocardia sp.

Der foreligger et Hvirvelparti af en Skal tilhørende denne Slægt.

Brudstykket er saa medtaget af Svovlsyreforvitring, at en nærmere Bestemmelse ikke er mulig.

\section{Familie: Cardiidae Fis cher (1887). \\ Genus: Cardium Linné (1758).}

Subgenus: (Laevicardium) SwaInson (1840).

13. Cardium (Laevicardium) subturgidum D'0 rbig n y

Tavle IV, Fig. 7.

1845. Cardium turgidum Brander. Nyst; Coqu. et Polyp. foss. de la Belgique, p. 190.

1868. sub Cardium comatulum Bronn; v. Koenen; Mitteloligocän; p. 98.

1892. Cardium subturgidum D’Orb. Lehmann I; p. 236.

1911.? " (Laevicardium) leptocolpatum Cossm. et Peyrot. Act. Linn. LXV, p. 138, t XXIII, f. 25-27.

1914. Cardium (Laevicardium)? subturgidum D'OrB. GrIPP; Itzehoe, p. 8.

Af denne Art foreligger 3 fuldstændige Fossiler med begge Skallerne bevaret, og desuden er fundet 3 Venstreskaller og 4 Højreskaller samt en Del Fragmenter.

Denne Cardium slutter sig nær til $C$. (Laevicardium) cyprium BRocomI (Kautsky 49 p. 37, t. 4. f. 7.), til hvilken Art KaUtsky ogsaa henregner den hos Rava omtalte Cardium comatulum Bronn (RAvn 95, p. 276, t. 1, fig. 25.); Bogsch (\%) er dog ikke af samme Anskuelse. C. subturgidum adskiller sig efter KaUTsky fra C.cyprium ved sin i Forhold til Højden 
større Længde. Skallerne fra Klintinghoved er imidlertid ikke, som nævnt af samme Forfatter, væsentlig mindre hvælvede end $C$.cyprium.

Oligocæn: Tyskland (m.)

Miocæn: Tyskland (n. m.), Belgien (Anversien) Vestfrankrig? (Tortonien)

14. Cardium (Laevicardium) cingulatum G $01 \mathrm{df}$.

1833-40. Cardium cingulatum Goldfuss; Petref. Germ. p. 222, t. 45, f. 4.

1845. " tenuisulcatum Nyst; Coqu.et Polyp.foss.dela Belgique;p.191.

1867-68. " cingulatum Goldf, v. Koenen. Mitteloligocän, p. 243.

$1870 . \quad "$ " $"$ Hoennes; II, p. 177, t. 25, f. 1.

1884. " " Speyer - v. Koenen, Cassel; t VII, f. $4-7$, t. VIII, f. $1-9$.

1914. " (Laevicardium) cingulatum Goldf. Roth v. Telegd ; p. 58.

1916. " cingulatum GoldF. NørRegaArd; p. 14, t. 1, f. 6.

1936. " (Laevicardium) cingulatum Goldf. Noszky; Mollusken-

1938. " cingulatum GoldF. GAÁL; Balassa-Gyarmat, p. 56.

Et Antal Skalfragmenter samt en lille Venstreskal henføres til denne Art. Oligocæn: Nordtyskland (n. m. ø.).

Miocæn: Danmark, Wiener Bækken (1. Medit.), Ungarn (Aquitanien).

\section{Familie: Veneridae Leach (1819). \\ Genus: Meretrix Lamarck (1799).}

Subgenus: (Cordiopsis) Cossm. (1909).

15. Meretrix (Cordiopsis) incrassata Sow.

1818. Venus incrassata Sowerby; Mineral Conch. II. t. 155, f. $1-2$.

1845. " " Nyst; Coqu. et Polyp. foss. de la Belgi1863. Cytherea " " $\quad$ que; p. 181. 23, f. 11, t. 24, f. $1-3$.
$1868 . \quad$ " $\quad$ v. Koenen; Mitteloligocän; p. 112.

1884. " " " $"$ Speyer-v. Koenen; Cassel; t. 6, f. 1 - 5.

1914. Meretrix " " Roth v. Telegd; p. 53, t. V, f. 10-11.

1914. (?) Amiantis islandicoides Laм. sp. Gripp; Itzehoe, p. 9.

1936. Meretrix incrassata Sol. Noszky; Molluskenfauna v. Eger; p. 89.

1938. " " GAÁl; Balassa-Gyarmat, p. 56.

var. flexicostulata $\mathrm{K}$ a u t s $\mathrm{k}$ y

Tavle IV, Fig. 9, 10.

1907. Meretrix incrassata Sow. Ravn; p. 278, t. II, f. 10.

1925. " " " var.flexicostulata. KAutsky; Hemmoor; p. 40, t. 4 , f. 10 .

Der foreligger et smukt bevaret Skalpar, som dog ikke har kunnet 
præpareres fra hinanden, endvidere bageste Del af Højre- og Venstreskal af samme Individ, hvor Skallens Indre og Hængselet har kunnet iagttages. Desuden er fundet en Højreskal samt et Hængselparti af en Højreskal.

Exemplarerne svarer godt til KAUTSKY's Beskrivelse men afviger fra det afbildede Exemplar ved at være lidt længere, hvilket maa anses for at være ret uvæsentligt. Det er iøvrigt et Spørgsmaal, om KaUtsky's Varietet bør opretholdes, da Meretrix incrassata efter Litteraturen godt kan variere en Del.

Den af Roth v. Telegd afbildede Skal afviger ogsaa ved sin større Længde sammenlignet med Klintinghoved Exemplarerne. At der imidlertid i Materialet fra Eger findes Skaller af omtrent samme Type som Klintinghovedskallerne, viser følgende Sammenstilling af Maalene for Bredde, Højde og Længde i mm og deres indbyrdes Forhold (efter Rотн v. Telegd).

\begin{tabular}{|c|c|c|c|c|c|}
\hline & & Bredde & Højde & Længde & Indbyrdes Forhold \\
\hline Skal fra & Klintinghoved. & 25 & 42 & 46 & $0,54: 0,91: 1$ \\
\hline \multirow{4}{*}{$\begin{array}{l}\text { Skaller } \\
\text { fra } \\
\text { Ungarn. }\end{array}$} & \multirow{2}{*}{$\begin{array}{c}\text { To runde Varieteter } \\
\text { fra Eger. }\end{array}$} & - & 31 & 34 & $-0,91: 1$ \\
\hline & & 24,5 & 34 & 36 & $0,68: 0,94: 1$ \\
\hline & Gennemsntl. Forh. af 5 Ex. & & & & $0,57: 0,84: 1$ \\
\hline & Lang Varietet. & 21 & 28,5 & 36,2 & $0,58: 0,79: 1$ \\
\hline
\end{tabular}

Meretrix incrassata findes i Aflejringer af følgende Alder:

Oligocæn: Næsten hele Evropa.

Miocæn: Danmark (m.), Nordtyskland (n. m.), Holland, Belgien (Boldérien) Ungarn (Aquitanien).

\section{Familie: Cyprinidae Pictet (1855). \\ Genus: Cyprina Lamarck (1812).}

16. Cyprina sp.

Der er fundet et mindre Brudstykke af en stor Skal, som uden Tvivl bør henregnes til Cyprina.

Familie: Tellinidae B1ainvil1e (1814) em. Genus: Tellina Linné (1758) em. Lamarck (1798).

17. Tellina fallax B e y ri ch

Tavle IV, Fig. 11, 12.

1839. Tellina Benedenii Nyst et Westendorp; ex parte. Nouv, rech. d'Anvers; p. 399, t. 2 , f. 5 , t. 3 , f. 5 . 
1843. Tellina Benedenii Nyst et Westendorp; Nyst; Coqu. et Polyp. foss. de la Belgique; p. 111.

1867. " fallax Beyr. v. Koenen; Mitteloligocän; p. 113.

1893. " " Lehmann; Dingden II; p. 277.

1907. " " RavN; p. 280.

1914. " " Gripp; Itzehoe; p. 9.

1916. " Benedenii Nyst et Westendorp; Nørregaard; p. 16.

1925. " fallax Beyr. Kautsky; Hemmoor; p. 42.

Af denne Art er fundet en velbevaret Skal med begge Halvdele bevaret, dog er et lille Hjørne af Bagranden brækket af paa begge Skaller. Endvidere er fundet 8 mere eller mindre fragmentariske Skalpar.

Baade Skallens Ydre og Indre samt Hængselet har kunnet studeres.

Da der i Litteraturen hersker en Del Diskussion om Muligheden af at henregne de under $T$. fallax fra Miocænet og under T. Benedenii fra Pliocænet omtalte Skaller til samme Art, skal der i det følgende gives en nøjere Beskrivelse af Skallerne fra Klintinghoved.

Skallen er trekantet-afrundet; Bagenden er mere spids end Forenden. Ryglinien er omtrent lige foran Hvirvelen og let convex bagved Hvirvelen. Forholdet mellem Højde og Længde ca. 1:1,6.

Skallen er blank, forsynet med almindelig Tilvækstskulptur samt mørkere og lysere Farvebaand, der følger denne.

Den bageste Del af Skallen er bøjet lidt til højre, af denne Grund synes venstre Skalhalvdel at være hvælvet en Ubetydelighed stærkere end Højreskallen. Fra Hvirvelen til Skallens Analende gaar umiddelbart langs med Ryggen en mere eller mindre udtalt smal Rende paa Skallens Overflade. Nedenfor denne Rende findes paa Højreskallen en bredere, svag Depression, der er betinget af den Omstændighed, at Bagenden, som nævnt ovenfor, er bøjet til højre.

Hængselets Formel: $\frac{\mathrm{L}: \mathrm{CoCo}(\mathrm{l})}{\mathrm{D}: \mathrm{oCoC} \mathrm{m} \mathrm{l}}$

Over forreste Lukkemuskelaftryk findes et Fodmuskelaftryk. Umiddelbart under Hængselet og lidt foran det ligger meget tæt ved hinanden to smaa og smalle Muskelaftryk.

Den dybe tungeformede Sinus naar hen til en Linie lodret under Fodmuskelaftrykket ved forreste Lukkemuskel og afsluttes lodret under bageste Lukkemuskelaftryks centrale Del.

Fra T.decipiens V. Kown. adskiller T. fallax samt $T$. Benedenii sig ved, at Skallens Bagende er bøjet stærkere til højre. Efter KAUtsky skulde atter $T$. fallax adskille sig fra $T$. Benedenii ved: 1. større Længde, 2. fladere Hængselsvinkel, 3. spidsere Bagende og 4. lige Forløb af bageste Dorsalrand.

Hvorvidt de anførte Karakteristika alle er lige væsentlige har jeg ikke 
været i Stand til at afgøre. Skønt Skallerne fra Klintinghoved har en svagt convex bageste Dorsalrand, har jeg henført dem til $T$. fallax, da det forekom mig at være for lille en Afvigelse til ikke at henføre dem til denne Art.

Miocæn: Danmark (m.), Nordtyskland (n. m.ø.). Holland, Belgien, (Boldérien, Anversien).

Familie: Scrobiculariidae Adams; Ghenu (1860) em.

Genus: Abra Leach (Teste Lamarck 1818, sine desc.).

18. Abra angulosa $\mathrm{R}$ e n. (= A. prismatica $M$ ont. $)$

Tavle IV, Fig. 13, 14.

1845. Ligula donaciformis Nyst; Coqu. et Polyp. foss. de la Belgique; p. 92, t. 4, f. 9

1867. Syndosmya angulosa Ren. Weinkauff; Conch. d. Mittelm. p. 54.

1874. Abra prismatica Mont. Wood; Crag Moll. II; p. 239, t. 22, f. 13.

1901. Syndosmya stricta Brocc. SAcco; XXIX; p. 121, t. 26, f. $25-28$.

1925. Abra angulosa Ren. Kautsky; Hemmoor; p. 45.

Der foreligger et lille, fuldstændig bevaret, toskallet Eksemplar, endvidere to større Skaller, der dog er en Del beskadigede, samt to letbeskadigede Højreskaller.

Som Kautsky nævner det, opstillede allerede Wennkauff A. prismatica og A. stricta som Synonymer til A. angulosa.

KAUtsky gør opmærksom paa, at $A$. marylandica GLenn (Calvert Formation) fra Nordamerika staar A. angulosa meget nær (Maryland Miocene, p. 296, t. LXXII, f. 10.). Den fra Maryland beskrevne Skal er meget lille; den har følgende Maal: Længde: $7 \mathrm{~mm}$, Højde: 4,5 mm, Tykkelse : 1,6 mm. Til Sammenligning kan anføres Maalene for det lille toskallede Exemplar fra Klintinghoved: Længde ca. $7 \mathrm{~mm}$, Højde: $4 \mathrm{~mm}$, Tykkelse: 1,7 mm. Det vil saaledes ses, at de i overordentlig høj Grad er i Overensstemmelse m. H. t. Størrelsesforholdene. Der synes dog at være indløbet en Fejl ved Tegningen af Skallen fra Maryland idet Kappeliniens Sinus ikke er tegnet med. Iøvrigt passer Skallen fuldstændig til Beskrivelserne af $A$. angulosa og maa højst sandsynlig henregnes til denne Art.

Miocæn: Nordtyskland (n. m.ø.) Holland, Belgien (Anversien) og Italien (Tortonien)

Pliocæn: Belgien, England, Italien.

Recent: Atlanterhavskysterne ved Norge, England, Spanien, Portugal og Middelhavet. 
Familie: Panopaeidae Zittel.

Genus: Panopaea Ménard de la Groye (1807).

\section{Panopaea Ménardi D e s h.}

Tavle IV, Fig. 15.

1854. Panopaea Ménardi Desh. Bayle; Not. géol. sur la prov. d’Oran. (Bull. soc. géol. 2 ser. t. XI, p. 510).

$\begin{array}{llcl}1870 . & " & " ~ & " \\ 1901 . & " & \text { " } \\ 1907 . & " & \text { sp. (?) } & \\ 1909 . & \text { Ménardi } & \text { " } \\ 1910 . & \text { " } & & \end{array}$

1925. Glycymeris Ménardi 1936. Panopaea 》 Hoernes; II. p. 29, t. II, f. $1-3$. SAcco; XXIX; p. 43 , t. 12 , f.4. RavN; p. 282. Cossmann et Peyrot; Act. Linn. LXIII; p. 195 , t. 3 , f. $40-41$.

》 Schaffer; Miocän v. Eggenburg; p. 96, t. 45, f. 4 , t. 46 , f. $1-2$.

1) Kautsky; Hemmoor; p. 48.

\) Bogsch; p. 63.

Af denne Art er fundet Skallerne til to Individer. Skallerne er en Del beskadigede.

Det drejer sig om relativt tyndskallede Exemplarer, der sidder fast paa Stenkærner; som Følge heraf kan f. Eks Hængselpartiet ikke studeres i hele sin Udstrækning. Interessant er det, at Ligamentet er bevaret hos begge Skaller.

Der kan ikke være Tvivl om, at disse to Fossiler tilhører Arten Panopaea Ménardi; de svarer godt til de af HoERnes afbildede Skaller, dog synes Kappebugten for den ene Skals Vedkommende, hvor den kan iagttages paa Stenkærnen, at være dybere end hos det af HoERNks afbildede Exemplar. Den nævnte Forfatter gør opmærksom paa, at Kappebugten varierer paa Skallerne fra Wien.

Panopaea Whitfieldi DALL fra Marylands Miocæn (Calvert og Choptank Formation) staar denne Art meget nær og er muligvis identisk med den (Maryland Miocene, p. 276, t. LXV, f. 10.)

Oligocæn: Italien (Tongrien).

Miocæn: Danmark (?), Nordtyskland (n. m.ø.), Holland, Belgien (Anversien), Vestfrankrig (Aquitanien, Burdigalien, Helvétien), Wiener Bækken (1. Medit., Grunder Sch. 2. Medit.) og Italien (Helvétien, Tortonien).

Familie: Thraciidae Dal1 (1903).

Genus: Thracia (Leach) Blainvil1e (1824).

20. Thracia ventricosa $\mathrm{Ph}$ il.

Tavle IV, Fig. 16.

1844. Thracia ventricosa Philippi; Enum. Moll. Siciliae II; p. 17.

1851-61. " 》 " " "

1870. " " $"$ HoERnes II; p. 48, t. 3, f. 15. 
1874. Thracia (?) ficiformis Møвсн; Forst. i Tert. Lag; p. 292.

1900. " ventricosa Philippi; V. Madsen; Kortbladet Bogense, p. 20.

1901. " convexa Wood; SAcco; XXIX, p. 136, t. 27, f. 21-23.

1907. " ventricosa Philippi; Ravn; p. 283, t. II, f. 11.

1916. " " " Nørregatrd; p. 18.

1925. " " " Kautsky; Hemmoor; p. 49, t. 5, f. 5.

1936. " convexa Woon; Noszky; Molluskenfauna von Eger, p. 91.

12 Exemplarer, der, som Følge af, at der her er Tale om en tyndskallet Art, er mere eller mindre beskadigede.

Der er intet nævneværdigt at bemærke til dem, udover at de er i god Overensstemmelse med Afbildningerne i Litteraturen.

I denne Sammenhæng skal understreges det af Kautsky omtalte nære Slægtskab, der synes at bestaa mellem denne Art og den nordamerikanske T. Conradi Couthour fra Marylands Miocæn (Maryland Miocene p. 359, t. XCV, f. 4). Jeg vil ikke anse det for usandsynligt, at det drejer sig om samme Art.

KaUtsky gør Rede for, at Navnet T. ventricosa og ikke $T$. convexa Woop tilkommer den her omtalte Form.

Miocæn: Danmark (m. ø.) Nordtyskland (n. m. ø.), Wiener Bækken (2. Medit.), Italien (Tortonien), Ungarn (Aquitanien).

Pliocæn: England, Belgien og Italien.

Familie: Cuspidariidae Dal1 (1886).

Genus: Guspidaria Nardo (1840).

Subgenus: (Cardiomya) A. Adanson (1864).

\section{Cuspidaria (Cardiomya) costellata Desh a yes}

Tavle IV, Fig. 17.

1832. Corbula costellata Deshayes; Exped. Scient. de Morée. III; p. 86, t. 24 , f. $1-3$.

1845. "Waeli Nyst; Coqu. et Polyp. foss. de la Belgique; p. 69, t. I, f. 5 .

1867. Neaera costellata Desh. Weinkauff; Conch. d. Mittelm. p. 29.

1909. Cuspidaria (Cardiomya) cf. costellata Desh. Cossmann et Peyrot; Act. Linn. LXIII, p. 108.

1915. Neaera (Cardiomya) costellata Desh. Gripp; Altmiocän, p. 33.

Af denne Art foreligger en Højre- og en Venstreskal samt et tveskallet Exemplar.

Skallerne passer godt til den af Nyst givne Beskrivelse.

Det største Exemplar, Højreskallen, maaler i Længde: 6,5 mm, Højde: 4,8 mm; den oprindelige Længde har været ca $7 \mathrm{~mm}$ idet Bagenden er let beskadiget. Det tveskallede Exemplar har en Læengde af ca. 4,5 mm, Højde $3,0 \mathrm{~mm}$, Tykkelse $2,1 \mathrm{~mm}$. 
De to Skalhalvdele er forskelligt udviklet, idet Venstreskallen er stærkest hvælvet, Højreskallen derimod har den største Højde.

Skallens Skulptur bestaar af forholdsvis stærkt udviklede Radialribber, der paa Skallens bageste Del er let kølede. Paa Skallens forreste Del er de temmelig tætliggende; Mellemrummene imellem dem har omtrent samme Bredde som Ribberne selv. Afstanden mellem Radialribberne tiltager mod Skallens bageste Del; her afslutter Skallens tre kraftigste Ribber Radialskulpturen, hvorefter Skallen løber ud i en rørformet Forlængelse, hvis Længde omtrent udgør en Trediedel af hele Skallens Længde. Dette Rostrum er ikke forsynet med Radialskulptur, men er langs Dorsalranden forsynet med 2 eller 3 fine linieformede Ribber.

Skallens Tilvækstlinier gør sig især gældende i Ribbemellemrummene, der er let konkave.

Det Indre af Skallen og Laaspartiet har ikke kunnet iagttages, da det drejer sig om Skaller, der sidder paa Konkretioner. Hvor Skallen er sprunget af Stenkærnen kan man se, at Radialribbernes Negativ gør sig gældende paa Skallens Inderside.

Efter NyST bestaar Laaspartiet af en Baandgrube samt en enkelt Tand.

Miocæn: Nordtyskland (n. m. ø.), Belgien (Boldérien), Vestfrankrig (Tortonien).

Pliocæn: Belgien, Syditalien.

Recent: Kysterne af Atlanterhavet (Norge, Storbritannien, Kanariske Øer) og Middelhavet.

\section{Scaphopoda.}

Familie: Dentaliidae Roemer (1836).

Genus: Dentalium Linné (1758).

Subgenus: (Antale) Aldrov. (1618).

22. Dentalium (Antale) vitreum Schröt.

1856. Dentalium entalis L. Hoernes I; p. 658, t. 50, f. 38 .

1845. 》 " Nyst; Coqu. et Polyp. foss. de la Belgique; p. 345.

1878-81. " " "

1883. " entale " v. Koenen; Miocän II, p. 237.

1897. Antale vitreum Schröt; SAcco; XXII, p. 100 , t. 8, f. $42-49$.

1914. Dentalium entale L. Gripp; Itzehoe, p. 10.

$1916 . " 》$ NørRegaArD; p. 20.

1925. " (Antale) vitreum Sснгӧт. Kautsky; Hemmoor; p. 52. 
Et Antal Brudstykker henregnes til denne Art.

Til den almindelige Beskrivelse i Litteraturen er der Grund til at tilføje, at de største Exemplarer fra Klintinghoved paa den yngste Del af Skallen har Tilløb til en meget svag Længdeskulptur i Form af meget svage, flade Ribber, der maaske nærmest bør karakteriseres som Undulationer i den glatte skinnende Skal, hvis Ensformighed ellers kun brydes af Tilvækstliniernes Skulptur.

Efter SACco henregner KaUtsky de i Synonymlisten opførte Skaller til Antale vitreum, da de miocæne Skaller i Modsætning til Dentalium entale L. ikke bærer Slids.

D. vitreum svarer baade ved sin Mangel paa Skulptur og paa Slids til Beskrivelsen, der er givet af D. caduloide DALL (Maryland Miocene, p. 272 , t. LXIV, f. 5.) men afviger fra denne ved at have en skinnende Skal.

Miocæn: Danmark (m.), Nordtyskland (n. m. .), Holland, Belgien (Boldérien, Anversien), Vestfrankrig (Burdigalien, Helvétien, Tortonien), Wiener Brkkenet (2. Medit.) og Italien (Helvétien, Tortonien).

Pliocæn: England, Belgien, Italien.

Subgenus: (Entalis) Gray (1840).

23. Dentalium (Entalis) badense Parts ch

1856. Dentalium badense Partsch; Hoernes; I, p. 652, t. 50, f. 30.

1874. " "

1883. " " v. Koenen. Miocän II, p. 323.

1897. Entalis badensis Partsch; SAcco; XXII, p. 107, t. IX, f. 17-20.

1907. Dentalium badense Partsch; Ravn; p. 288, t. III, f. 3.

1915. Entalis badensis Partsch; Cossmann et Peyrot; p. 175, t. I, f. $12-13,16$.

1925. Dentalium (Entalis) badense Partsch var. borealis Kautsky; Hemmoor; p. 53, t. 5, f. 12 .

Til denne Art henregnes 3 Skalbrudstykker:

$\begin{array}{lccc} & \text { I } & \text { II } & \text { III } \\ \text { Diameter: } & 4,7 & 4,3 & 3,4 \mathrm{~mm} . \\ \text { Antal Ribber: } & 13 & 14 & 14\end{array}$

Det karakteristiske for denne Skal i Modsætning til andre Dentalier, der ligner denne, f. Eks. D. mutabile Dödertern og D. Dollfusi v. Koen., er at den paa Ribberne, hvis Antal kan variere meget med Skallens Størrelse, og i Mellemrummene mellem disse bærer en Skulptur af fine Længdestriber. Disse skæres atter af Tilvækstlinierne, saaledes at der paa visse Dele af Skallens Overflade dannes et fint Netværk. 
KaUtsky opstiller Varieteten boreatis, der skulde kendetegnes ved sit Størrelse, Skallens store Bredde ved Basis og bredere og fladere Ribber, hvorved den skulde adskille sig fra Wiener Skallerne. Da det imidlertid af Litteraturen fremgaar, at ogsaa Wiener Exemplarerne, der maa betragtes som Typen paa denne Art, varierer stærkt i disse Henseender, maa Opstillingen af en ny Varietet paa Basis af de anførte Karakteristika anses for ikke at være tilstrækkelig begrundet.

Miocæn: Danmark, Nordtyskland (n. m. ø.), Belgien (Anversien), Wiener Bækkenet (2. Medit.), Vestfrankrig, Italien (Aquitanien, Burdigalien, Helvétien).

Pliocæn: Italien.

\title{
3. Gastropoda.
}

\section{A. Prosobranchia.}

\author{
Familie: Xenophoridae Deshayes (1864). \\ Genus: Xenophora Fis cher von Waldheim (1807).
}

\section{Xenophora Deshayesii $\mathbf{M}$ i $\mathrm{ch}$.}

Tavle V, Fig. 1, 2.

\begin{tabular}{|c|c|c|c|c|}
\hline 1856. & Xenophora & Deshayesi & Мiсн. & Hoennes; I, p. 442, t. 44, f. 12. \\
\hline 1883. & $»$ & Deshayesii & " & v. Koenen; Miocän II, p. 305. \\
\hline 806 & 》 & Deshayesi & " & SACCO; XX, p. 20, t. 2 , f. 20. \\
\hline 914 & " & $»$ & $"$ & Rотн v. Telegd; p. 46. \\
\hline & 》 & Deshayesii & " & NørregaArd；p. 20 \\
\hline & " & Deshayesi & $"$ & Kautsky; Hemmoor; p. 63 , t. 6 , f. 9. \\
\hline & ") & $»$ & " & Noszky; Molluskenfauna v. \\
\hline
\end{tabular}

Af denne Art er fundet een Skal, Højde: $24 \mathrm{~mm}$, Bredde 26,5 mm. Skallen er lidt beskadiget paa Embryonalskal og Slutningsvinding.

De Fremmedlegemer, der har siddet paa Skallen, har hovedsagelig været Skaller af Cardium subturgidum.

Basis af Slutvindingen bærer paa sin inderste Halvdel nærmest den calløse Navle 4 flade Spiraler, den yderste Del derimod bærer kun Tilvækstlinier. Herved slutter den sig efter Roth v. Telegd til den ældre, oligocæne, sydlige Formkreds, idet de miocæne Skaller efter denne Forfatter bærer saadanne Spiraler paa hele Basis.

Oligocæn: Italien (Tongrien).

Miocæn: Danmark, Nordtyskland (n.m.ø?), Holland, Belgien (Boldérien, Anversien) Vestfrankrig (Burdigalien), Wiener Bækkenet (Grunder Schichten, 2. Medit.), Italien (Helvétien).

Pliocæn: Italien. 


\section{Familie: Solariidae Bronn (in Ghenu 1859).}

Genus: Solarium La marck (1799).

\section{Solarium Dumontii N y s t}

Tavle V, Fig. $3-5$.

1845. Solarium Dumontii Nyst; Coqu. et Polyp. foss. de la Belgique, p. 369, t. XI, f. 6 .

1867. " " v. Koenen; Mitteloligocän, p. 59.

1882. " " var. postera v. Koenen; Miocän, p. 302.

1923. "Dumonti " Harmer; Pliocene Mollusca, Vol. II, Part III, p. 853, t. LXIX, f. 39.

Der er af denne Art fundet to ret velbevarede Skaller.

I det følgende skal gives en Beskrivelse af det største Exemplar.

Skallen er diskoïd med ret fladt Spir. Skallens Bredde er 18,7 mm, Højden $4 \mathrm{~mm}$ og Skallen bestaar af $4^{1} / 2$ Vinding.

Embryonalskallen bestaar af $1^{1 / 2}$ Vinding, den er slidt og dens Skulptur kan derfor ikke erkendes, efter Nyst har den en glat Overflade.

De følgende tre Vindinger er udviklet som Slutningsvindingen; denne bærer paa Skallens Overside et Antal (ca. 50) let tilbagebøjede Tværribber. Paa sin Yderside bærer Slutningsvindingen tre kraftige Spiralribber adskilt fra hinanden og fra Skallens Over- og Underside ved 4 dybe Furer. Disse Spiralribber har Snoreskulptur som Følge af, at Oversidens Tværribber fortsætter sig ud paa Spiralerne. Den midterste Spiral er den kraftigste, den nederste den svageste.

Undersiden af Slutningsvindingen deles ved 2 Spiralfurer i tre karakteristiske spiralformede Partier. Det inderste af disse nærmest Navlen indtager ca. ${ }^{1 / 5}$ af Undersidens Bredde. Det er forsynet med 20 kraftige Tværribber. Den inderste Rand af Slutningsvindingen hvælver sig lidt ind over Navlen.

Det midterste spiralformede Parti indtager $2 / 5$ af Undersidens Bredde og er forsynet med dobbelt saa stort et Antal Tværribber som Inderspiralen; Tværribberne er lidt finere end Inderspiralens.

Det yderste spiralformede Parti indtager de sidste $2 / 5$ af Undersidens Bredde. Langs Grænsen til Mellempartiet findes ca. dobbelt saa stort et Antal eller lidt færre Knuder, som der findes Tværribber paa Mellempartiet. Knuderne er af samme Størrelsesorden som disse. De deler sig udefter hver i 2-4 fine lave Tværribber, hvor de støder op til den nederste af Ydersidens Spiraler. Disse sidste yderste lave Tværribber skæres af 4-5 meget fine Spiralfurer, der kan ses under Loupe.

Suturen anlægges i Furen mellem Ydersidens øverste og midterste Sidespiral. Den øverste Snore-Spiral udgør herefter en Del af Skallens Overside.

Mundingen er ikke helt bevaret, men kan ved Hjælp af de gamle 
Mundrande, og hvad der iøvrigt er bevaret, karakteriseres saaledes: Idet den følger Tværribbernes Form paa Skallens Overside bøjer Mundranden lidt tilbage. Paa Siden af Skallen bøjer Randen vedblivende tilbage, hvorefter den paa Undersiden atter bøjer fremefter, dog paa den Maade at nederste Mundrand ligger bagved øverste. Ved Navlen danner Mundranden omtrent en ret Vinkel med en lille kort Kanal i Vinkelspidsen og gaar herefter op til forrige Vinding. Ind mod Navlen er Mundranden konkav.

Navlen har forneden omtrent samme Diameter som Slutningsvindingens Bredde.

Skallerne svarer godt til Nyst's og v. Koenen's Beskrivelser, dog er de ikke saa spidsvinklede som den af Nyst afbildede Skal. Denne Karakter varierer dog efter Nyst hos de belgiske Skaller.

Oligocæn: Nordtyskland (m. ø.), Belgien (ø.).

Miocæn: Nordtyskland (n.).

Pliocæn: England.

Familie: Naticidae For bes (1838).

Genus: Natica Adanson (1757).

Subgenus: (Lunatia) GraY (1847).

26. Natica (Lunatia) helicina B r o c ch i

Tavle V, Fig. 5.

1868. Natica helicina Brocchi; Weinkauff II; p. 249.

1872. " " " $"$ "Koch u. Wiechmann; p. 80.

1880. " " " $"$ v. Koenen; Miocän; p. 231.

1890. " catena var. helicina SAcco VIII; p. 70, t. II, f. 43.

1907. " helicina Brocсні; RavN; p. 294, t. III, f. 11.

1914. " " Roth v. Telegd; p. 31.

1914. " " " " "

1916. " " NørregaArd; p. 22.

1918. " (Lunatia) helicina Brocchi; Cossmann et Peyrot; Act. Linn. LXX, p. 228, t. XI, f. 39-41, t. XII, f. 29, 54.

Der er fundet 16 mere eller mindre vëlbevarede Skaller. De svarer godt til Ravns Afbildning og Beskrivelse. Spirets Højde og Hvælvethed varierer en Del.

Skallerne af denne Art minder, som de fleste tidligere Autorer har nævnt, meget om de Skaller, der er henregnet til N. Nysti D'OrBIGNy fra Oligocænet. Det er et Spørgsmaal, om det ikke drejer sig om samme Art. De Kendetegn, der anføres til deres Adskillelse kan variere meget, saaledes at man ikke ad de anviste Veje kan naa til nogen eentydig Bestemmelse.

Der er ikke fundet Skaller med Operculum, som efter v. Koenen er afgørende for Bestemmelsen; der skal derfor ikke diskuteres, hvorvidt de to Arter er identiske eller ej. 
Da de miocæne Former i Litteraturen er henført til N.helicina, selvom SACCO (VIII, p. 68.) anser dem for at være en Varietet af N. catena Da Costa, og som han benævner var. cyclostomoides SAcco, henføres de ved Klintinghoved fundne Skaller med Forbehold til $N$. helicina Brocc.

Efter Kautsky findes $N$. catena DA Costa i:

Miocæn: Danmark, Nordtyskland (n. m. ø.), Holland, Belgien (Boldérien, Anversien), Vestfrankrig (Helvétien, Tortonien), Wiener-Bækkenet (Grunder Schichten, 2 Medit.) Italien (Helvétien, Tortonien).

Pliocæn: alle europæiske Aflejringer.

Recent: hele Europa med Undtagelse af Polarregionen.

Subgenus: (Polinices) Montfort (1810).

27. Natica (Polinices) submammillaris D'0 rbig ny

1890. Natica submamillaris D'Orbigny; SACCo; VIII p. 90, t. 2, f. 62.

1882. " Josephinia Risso; v. Koenen; Miocän, II p. 231. pars.

1907. " " RavN; Jylland, p. 291, t. 3, f. 7.

1914. " (Neverita)" " Roth v. Telegd; p. 31.

1916. " " "sp. Nørregard; p. 22.

1925. " (Polinices) submamillaris D’Orbigny. Kautsky; Hemmoor; p. 71, t. 6 , f. $24-25$.

Der er fundet een ret velbevaret Skal; Mundingens Yderlæbe samt sidste Vinding er lidt beskadiget.

Skallen svarer fuldstændig til Kautskys Afbildning. Efter denne Forfatter adskiller N. submammillaris sig fra N. Josephinia ved, at Navlen ikke er dækket af nogen Vulst, og desuden ved at besidde et højere Spir.

Som nævnt af RAVN og KAUTSKY staar Skallerne af denne Art i deres Udvikling meget nær ved den oligocæne N.hantoniensis PזL.

Miocæn: Danmark (m. ø.), Nordtyskland (n. m.), Holland, Belgien (Anversien), Wiener Bækkenet (Grunder Schichten) og Italien (Helvétien, Tortonien).

\section{Familie: Pyramidellidae Gray (1847). \\ Genus: Pyramidella Lamarck (1799).}

\section{Pyramidella plicosa B r o n n}

1838. Pyramidella plicosa Bronn; Lethaea geognostica II; p. 1026, t. 40, f. 24. 1848. " laeviscula Wood; Crag Moll. I; p. 77, t. 9, f. 2.

1856. " plicosa Bronn; Hoernes I; p. 492, t. 46, f. 20.

1882. " " v. Koenen; Miocän II; p. 239, t. 6, f. 15. 
1892. Pyramidella plicosa Bronn; SAcco XI; p. 27, t. I, f. 53.

1907. " " " RAvN; p. 300, t. 3, f. 22.

1917. " " " Cossmann et Peyrot LXX; p. 95, t. IX, f. $8-9$.

1925. " " " Kautsky; Hemmoor; p. 72.

1936. " " " Bogsch; Nógrádszakál; p. 72, t. III, f. 41.

Een velbevaret Skal med følgende Maal: Bredde: 1,7 mm, Højde 3,8 m. Skallen bestaar af 6 Vindinger.

Denne Art er meget nær beslægtet med P. conulus Speyer, som højst sandsynlig ogsaa maa henregnes til denne Art, da de Karakteristika, der anføres i Litteraturen til deres Adskillelse, synes at variere i saa høj Grad, at det vil være vanskeligt at opretholde de to Arter (SPEYER; Cassel; p. 183, t. 25, f. 1.).

Miocæn: Danmark (m. ø.), Nordtyskland (n. m. ø.), Belgien (Anversien), Vestfrankrig (Burdigalien, Helvétien, Tortonien), Wiener Bækkenet (2 Medit.), Italien (Helvétien, Tortonien), Ungarn (Tortonien).

Pliocæn: alle europæiske Aflejringer.

Familie: Eulimidae H. et A. A d a m s (1854).

Genus: Eulima Ris so (1826).

\section{Eulima subula D'0 r b ig n y}

1852. Eulima subula D’Orbigny; Prodrome de Pal. III; p. 34.

1870. " " SPEYer; Cassel p. 204, t. XXVII, f. 7.

1872. " " Косн u. Wiechmann; p. 114.

1914. " " GRIPP; Itzehoe; p. 13.

Der er fundet en Skal velbevaret paa nær Mundingen, der er lidt beskadiget. Højde: 3,75 mm, Bredde: 1,05 mm. Endvidere er fundet Slutningsvindingen tilhørende en større Skal.

Skallen svarer godt til den af Speyer givne Afbildning. Vindingerne besidder ingen Konvexitet, som Følge heraf er Skallen spids kegleformet. Vindingerne, der følger umiddlebart paa Embryonalskallen, er til at begynde med svagt konvexe.

Skallens Overflade er fuldstændig glat, Tilvækstlinierne kan skimtes under Loupe.

Som nævnt hos GRIPP adskiller denne Form sig fra Skallen af $E$. flexuosa v. Koen. ved den mindre skraat løbende Sutur og de lige, skraat til venstre løbende Tilvækststriber.

Oligocæn: Kassel (ø.).

Miocæn: Nordtyskland (n.). 


\section{Familie: Turritellidae G1a r k (1851). \\ Genus: Turritella Lamarck (1792).}

\section{Turritella Geinitzi Speyer}

Tavle V, Fig. 7-9.

1866. Turritella Geinitzi Speyer; Detmold; p. 22, t. II, f. $1-5$.

1869. " " " Cassel; p. 145, t. XX, f. 8-12.

$1882 . \quad " \quad$ v. Koenen; Miocän II; p. 290.

1914. " Sandbergeri Mayer; Roth v. Telegd; p. 43, t. IV, f. 21-24.

1914. " Geinitzi Speyer; Gripp: Itzehoe; p. 12, t. 1, f. 6-13.

1915. " " " Altmiocän; p. 33.

1936. " Sandbergeri Mayer; Noszky; Molluskenfauna von Eger p. 57.

Der er fundet et stort Antal Skalfragmenter; paa ingen af Stykkerne er Mundingen eller Embryonalskal bevaret.

Spiralskulpturen varierer, som nævnt af SPeyer, v. Koenen og GripP, meget i Løbet af Skallens Udvikling. Paa den yngste, nederste Del af Skallen findes et stort Antal omtrent lige store Spiraler. Paa ældre Mellemvindinger findes ofte tre særlig kraftige Spiraler, hvorimellem der indskyder sig finere. Den ældste Del af Skallen bærer til at begynde med kun een kraftig Spiral. Efter GRIPP er Embryonalskallen fuldstændig glat.

Vindingernes Profil bliver fra oven og nedefter paa Skallen: konvex kølet med kraftig Midterribbe, derefter mere flad, for til sidst, som iagttaget paa de største Skaller, at gaa over til foroven paa Vindingen at være svag konkav og forneden svagt konvex eller flad.

Skulpturen er paa Skallerne fra Klintinghoved gennemgaaende kraftigere end hos de af GRIPP afbildede Exemplarer, overensstemmende med Speyers f. $9-10$, t. XX.

Roth v. Telegd, der med noget Forbehold henfører Skaldele fra Ungarn til T. Sandbergeri MAYER, giver en udtømmende Beskrivelse af Skallernes Spiralskulptur, der viser, at disse Skaller er i stor Overensstemmelse med Skallerne fra Klintinghoved med Hensyn til denne Karakter.

Oligocæn: Nordtyskland (m. ø.), Mellemtyskland (ø.), Ungarn (Aquitanien), Siebenbürgen (Aquitanien).

Miocæn: Nordtyskland (n.).

\section{Familie: Cerithidae Féruss a c (1821). \\ Genus: Bittium (Leach), Gray (1847).}

31. Bittium convexorude S a c co

Tavle V, Fig. 10.

1895. Bittium spina Partsch var. convexorudis SAcco; XVII, p. 41, t. II, f. 121.

1921. " convexorude Sacco; Cossmann et Peyrot; LXXIII, p. 281,

t. VII, f. $21-24$. 
1936. Bittium spina Partsch var. convexorudis Sacco; Noszky; Molluskenfauna v. Eger; p. 58.

Skaller tilhørende denne Art er meget hyppige; der er indsamlet ca. 40 mere eller mindre velbevarede Exemplarer.

Cossmann et Peyró, der nøje har studeret de forskellige BittiumArter fra neogene Aflejringer i l'Aquitaine, opstiller den af SACCO som B. spina var. convexorudis beskrevne Form som selvstændig Art, idet denne efter disse Forfattere fjærner sig en hel Del fra den fra Wienerbækkenet beskrevne B. spina Partsch.

Af Skallens Karakteristika skal nævnes følgende: Embryonalskallen bestaar af ca. 3 glatte Vindinger. Den første Mellemvinding bærer to Spiraler, der er ret kraftige, og som krydses af Tværribber. Der slutter sig ved de næste Mellemvindinger over disse Spiraler hurtigt først een og senere endnu en Spiral til disse to, saaledes at Mellemvindingerne til sidst, omtrent fra 4de Mellemvinding, bærer 4 saadanne Spiraler. Den øverste følger Suturen og er ret svag; Afstandene mellem de 4 Spiraler er inæquidistante. Benævner vi Spiralerne, 1, 2, 3 og 4 fra øverste Sutur til nederste, er Afstanden mellem 1 og 2 mindre end mellem 2 og 3, og denne Afstand er atter mindre end den mellem 3 og 4. Spiralerne krydses som nævnt af buede Tværribber, hvis Afstand er mindre end Afstanden mellem Spiral 3 og 4: herved fremkommer paa Krydsningspunktet smaa Torne. Imellem Primærspiralerne indskyder sig paa de yngste Vindinger fine Sekundærspiraler.

Mundingen er rund og løber forneden ud i en lille flad, spids Kanal. Paa Undersiden af Slutningsvindingen findes to glatte Spiraler langs med Kanten.

Saa vidt det kan ses paa Afbildningerne af B. spina hos M. Hoernes, er der ogsaa stor Overensstemmelse med denne Form fra Wiener Bækkenet. Da det imidlertid ikke har været muligt at sammenligne med Skaller herfra, kan denne Formodning ikke bekræftes. Imellem de under B. spina beskrevne Skaller fra Nordsøbækkenet findes sikkert en Del, der maa henføres under B. convexorude SACCO.

Miocæn: ?Nordtyskland (n. m.) ?Holland, Belgien (Anversien), ?Wiener Bækkenet (2 Medit.), Italien (Helvétien), Vestfrankrig (Tortonien), Ungarn (Aquitanien).

Genus: Newtoniella Cos s mann (1893).

Subgenus: (Seila) Adays (1861).

32. Newtoniella (Seila) cyrtogyra Cos m. et Pey rot

Tavle V, Fig. 11.

?1907. Cerithium Genei Michelotti; Ravn; p. 301, t. III, f. 23.

1921. Newtoniella (Seila) cyrtogyra Cossmann et Peyrot; LXXIII; p. 301,

t. VII, f. 3 . 
Der foreligger de nederste 21/2 Vindinger af en ellers velbevaret Skal; Diameter ved sidste Vinding: 1,7 mm, Skallens oprindelige Længde ca. $6,5 \mathrm{~mm}$.

Mundingen er oval med en spids, kort Kanal, der er bøjet til venstre.

Sidste Vinding deles ved en nederste glat Spiralribbe i en basal og en lateral Del.

Den basale Del staar tilnærmelsesvis vinkelret paa Columella og er glat; under Loupe ses talrige seglformede Tilvækstlinier.

Den laterale Del af Slutningsvindingens Overflade er som nævnt nedad begrænset ved en fuldstændig glat Spiralribbe. Over den følger med samme Afstand imellem hinanden tre kraftigere, kølagtige Spiraler, der har Perlesnorform, idet de er tykkest, hvor de skæres af Tværribberne, hvoraf der findes ca. 40 for hver Vinding. Den øverste af disse tre Spiraler ligger tæt op til Suturen, skilt fra denne ved to meget fine Spiraler. De tre Perlesnorspiraler og den nederste glatte Spiral er indbyrdes æquidistante.

Suturen anlægges umiddelbart op til den glatte Spiralribbe.

De enkelte Vindinger er svagt konvexe.

Fra Newtoniella (Seila) trilineata PHIL. adskiller Skallerne af N.cyrtogyra sig ved Vindingernes Konvexitet og de tre Spiralribbers Perlesnorform. Det af Ravn under Cerithium Genei Mich. beskrevne Stykke synes efter Beskrivelsen ogsaa at høre herhen $\left.{ }^{1}\right)$.

Miocæn: Vestfrankrig (Aquitanien), Danmark (?)

\section{Familie: Aporrhaidae A da m s}

Genus: Chenopus. Philippi (1836).

33. Chenopus speciosus S chloth.

Tavle V, Fig. 12.

1854. Aporrhais speciosa Schlotherm sp. Beyrich; p. 170, t. 11, f. 1 -6.

\begin{tabular}{|c|c|c|c|c|c|}
\hline 1863. & $"$ & 》 & BEYR. (spec. & $\mathrm{ScHI}$ & $\begin{array}{l}\text { Loth.). Speyer; Cassel; p. } 62 \text {, t. } 7 \text {, } \\
\text { f. } 1-5 .\end{array}$ \\
\hline 1882. & $»$ & 1) & SCHLOTHEIM & $s p$. & v. Koenen; Miocän II, p. 278. \\
\hline 1907. & $"$ & ) & 》 & $"$ & RAvN; p. 302, t. 3, f. 24 \\
\hline 1913. & $"$ & " & 》) & " & HARDER; p. 74, t. 6 , f. 1,2 . \\
\hline 1914. & Chenopus & speciosus & 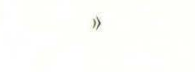 & ") & $\begin{array}{l}\text { Roth v. Telegd; p. } 37 \text {, t. } 4 \text {, } \\
\text { f. } 16-17 .\end{array}$ \\
\hline 1914. & Aporrhais & speciosa & $"$ & & $\begin{array}{l}\text { GripP; Itzehoe; p. } 14 \text {, t. } 1 \text {, } \\
\text { f. } 18-21 .\end{array}$ \\
\hline 1916. & 》 & $\gg$ & 》) & $"$ & Nørregaard； p. 24 \\
\hline 1925. & Chenopus & speciosus & ) & " & KAutsky; Hemmoor; p. 85. \\
\hline 1936. & $»$ & $》$ & " & $"$ & $\begin{array}{l}\text { var. Noszky; Molluskenfauna v. } \\
\text { Eger; p. } 61 .\end{array}$ \\
\hline
\end{tabular}

1) Ravn's Originalexemplar, der opbevares paa Universitetets Mineralogiske Museum, København, er i saa høj Grad ødelagt af Forvitring, at Enkelthederne ikke kan iagttages. 
var. Margerini DE KonINCK

1854. Aporrhais speciosa Schlotherm sp. Beyrich; p. 175, t. 11, f. $1-3,6$.

Skaller af denne Art er meget hyppige. Der er fundet ca. 20 mere eller mindre defekte Skaller, som passer godt til Afbildningerne hos Beyrich, Speyer, Ravn og Gripp og maa henføres til var. Margerini DE Koninck.

Denne Arts Skaller varierer efter Litteraturen meget i Udseende. 1854 delte Beyrich dem i to store Grupper, var.megapolitana Beyr., der er mindre, og hvor anden Knuderække paa Slutningsvindingen ikke er udviklet som Køl, medens var. Margerini er større, og anden Knuderække er udviklet som Køl med udviskede Knuder. Mundingens Yderog Inderlæbe er ofte meget stærkt fortykkede.

Disse Karakteristika synes dog ikke alle at være konstante, f. Eks. findes paa en Skal fra Klintinghoved i Stedet for Køl (anden Knuderække) veludviklede Knuder.

Det er dog ikke muligt her at give en bedre Diagnose paa Varieteterne, da det tilstrækkelige Materiale til Sammenligning mangler.

Efter GRIPP kan C.speciosus, naar den optræder i store Mængder bruges som »Ledefossil« for nedre Miocæn. Var. Margerini findes i Nordeuropa i Tidsrummet Mellemoligocæn-Mellemmiocæn, bemærkelsesværdigt er det, at den ogsaa findes ved Kap Dalton (94) ${ }^{1}$ ).

Øjensynlig uden at have Kendskab til Roth v. TelegD's Afhandling mener KaUtsky at kunne fastslaa, at Chenopus speciosus er indskrænket til Nordsøbækkenet. Den af Rотн v. Teleqd citerede Afhandling viser imidlertid, at man ogsaa indenfor Omraader, der henregnes til de mediterrane, har funder Repræsentanter for denne Art.

Oligocæn: Danmark (m.ø.), Nordtyskland (n.m.ø.), Mellemtyskland. Miocæn: Danmark, Nordtyskland (n. m.), Ungarn (Aquitanien).

\section{Familie: Cypraeidae Gray (1824). \\ Genus: Cypraea Linné (1740).}

Subgenus: (Zonaria) Jousseaume (1884).

34. Cypraea (Zonaria) amygdalum B rocc.

Tavle V, Fig. 13.

1856. Cypraea amygdalum Brocc. Hoernes I; p. 67, t. 8, f. $6-8$.

1872. " " $"$ v. Koenen; Miocän I; p. 256.

1880. "(Aricia) " " Hoernes u. Aunnger; p. 60 , t. 8, f. $4-5$.

1894. Zonaria fabagina LAm. var. amygdalum Brocc. SAcco XV, p. 21, t. 2, f. 12.

1922. Cypreaea (Adusta) subamygdalum D'Orbigny; Cossmann et Peyrot

LXXIV; p. 291, t. IX, f. 22-23, t. X, f. 5 .

1925. Cypraea (Zonaria) amygdalum Brocc. Kautsky; Hemmoor; p. 86, t.7, f. 9.

1) Aporrhais Margerini fra the Oldhaven Beds er maaske identisk med var. Margerini. 
En delvis bevaret Skal bestaaende af Mundingen og de ældste Dele af Skallen.

Dette Exemplar svarer især godt til Afbildningen hos HoEnnes u. Aunnger og Kautsky. Det maaler i Højde 33,5 mm i Bredde $24 \mathrm{~mm}$.

Miocæn: Nordtyskland $(\mathrm{m})$, Holland, ?Belgien (Anversien), Vestfrankrig (Burdigalien, Tortonien), Wiener Bækkenet (Grunder Sch., 2 Medit.) og Italien. (Helvétien).

Familie: Doliidae H. et A. Adam s (1854).

Genus: Pyrula Lama rck (1799).

35. Pyrula simplex Beyrich

Tavle V, Fig. 14.

1856. Pyrula simplex Beyrich; p. 230, t. 15 , f. 3 .

1863. " " " SPEyer; Cassel; p. 83, t. IX, f. 16-17.

1872. Ficula " " v. Koenen; Miocän I, p. 168.

1874. Pyrula " " Мøвсн; р. 286.

1907. " " RAvN; p. 310.

1925. " " KaUtsky; Hemmoor; p. 87, t. 7, f. 10.

Af denne Art er fundet 3 velbevarede store Skaller samt 3 lidt defekte Stykker. Det største Exemplar maaler: Længde 32,7 mm, største Diameter: $24,2 \mathrm{~mm}$.

Denne Arts Skal karakteriseres ved sin Spiralskulptur af talrige flade Spiraler, hvis Afstand kan variere en Del. Imellem Varices, der især kan iagttages paa Slutningsvindingen, kan disse Spiraler forskydes lidt. De forskellige Varices understreges ved en calløs Kalkafsondring over Suturen paa den foregaaende Vinding.

KaUtsky nævner, at denne Form staar P. Harrisi MaRt. meget nær. P. Harrisi fra Nordamerikas Miocæn ( 6 , p. 226, t. 50, f. 3) afviger efter Afbildningen i Litteraturen fra Skallerne fra Klintinghoved ved, at Spiret er lavere. Da denne Karakter muligvis er varierende, drejer det sig maaske om identiske Arter.

Oligocæn: Nordtyskland (ø.).

Miocæn: Nordtyskland (n. m.), Belgien (Anversien).

Familie: Cassididae Herrmannsen

Genus: Cassidea B rugui ère (1792).

Subgenus: (Semicassis) KLeTn (1753).

36. Cassidea (Semicassis) Rondeletii B a ste r ot.

Tavle V, Fig. 15.

1854. Cassis Rondeletii Bast. Beyrich; p. 151; t. 10, f. $4-6$.

1863. " subventricosa Speyer; Cassel, p. 50, t. 4, f. 14. 
1863. Cassis Sandbergeri Speyer; Cassel, p. 52, t. 4, f. 13 , t. 5 , f. $2-3$.

1863. "elongata " p. 54 , t. 5 , f. $6-7$.

1864. " Hertha SEmp. " Söllingen. p. 13.

1867. " Rondeletii Bast. v. Koenen; Mitteloligocän; p. 32.

1872. " " " " Miocän I; p. 205.

1874. " (Cassidea) Rondeletii (Bast.) Beyr. Мørсh; p. 285.

1907. " " Basterot; RavN; p. 307, t. IV, f. 9.

Der er fundet 3 velbevarede Skaller, hvoraf det afbildede største Exemplar mangler Kanal; det maaler i Højde: $58 \mathrm{~mm}$, Diameter: $32 \mathrm{~mm}$.

Litteraturen viser, at der her er Tale om en Art, hvis Skal varierer en Del, idet den har givet Anledning til Oprettelsen af flere Arter. Baade Skallens Udseende og Skulptur kan variere, saaledes at man træffer slankere og kortere Former med kraftige og mindre kraftige Skulpturelementer.

Denne Arts Skal kan meget nemt forveksles med Skallen af Cassidea (Semicassis) megapolitana BEYR., da de staar hinanden meget nær, idet de har næsten samme Udseende. Til deres Adskillelse skal derfor anføres nogle Karakterer, som efter Litteraturen synes at være nogenlunde konstante.

Ser man paa Slutningsvindingen hos $C$. Rondeletii findes der øverst mod Suturen udviklet en ophøjet Spiral med Knuder; længere nede paa Vindingen følger dernæest Vindingens to stærkest udviklede Spiraler, de saakaldte Mellemspiraler. Under dem er udformet 9 (eller 8) svagere nedre Spiraler, der aftager i Højde nedefter. Ind imellem disse indskyder sig svage Sekundærspiraler, der paa den nederste Del af Vindingen kan nærme sig Primærspiralerne i Størrelse.

Slutningsvindingen hos C. megapolitana er udviklet paa lignende Maade, der findes saaledes en øverste Suturspiral, der dog er forholdsvis svagere end hos $C$. Rondeletii, og den kan næsten forsvinde fuldstændig. Dernæst følger de to Mellemspiraler, der ogsaa er svagere udviklet m. H.t. Relief og Knudrethed end de tilsvarende hos $C$. Rondeletii. En afgørende Forskel mellem de to Formers Skal viser sig imidlertid i Udformningen af de nedre Spiraler, idet der af disse hos C. megapolitana findes et Antal af 16 (eller 15), hvis Knuder er næsten fuldstændig udjævnet. Dette i Forhold til $C$. Rondeletii store Antal Spiraler kan maaske forklares ved, at Sekundærspiralerne og Primærspiralerne hos C.megapolitana har nærmet sig hinanden i Størrelse, hvorefter der faas et samlet Antal Spiraler, der er lig Summen af nedre Spiraler og de imellem disse liggende Sekundærspiraler med en lille Afvigelse (BEYRICH).

Oligocæn: Danmark (m. ø.), Nordtyskland (m.ø.), Italien (Tongrien). Miocæn: Danmark (m. ø.), Nordtyskland (n. m. .), Belgien (Anversien), Vestfrankrig (Burdigalien), Italien (Helvétien). 


\section{Familie: Tritoniidae B roderip (1839). \\ Genus: Tritonium Linck (1807).}

\section{Tritonium (Simpulum) enode B e y r i h}

Tavle V, Fig. 16.

1854. Tritonium enode Bexнich; p. 188, t. 12, f. 7 .

1868. " " " SPeyer; Lippe-Detmold, p. 16, t. I, f. 9.

1872. " " v. Koenen; Miocän I; p. 154.

1914. Triton (Simpulum) enodis" GrIPp; Itzehoe; p. 16, t. II, f. 1-4.

Der er fundet 15 Skaller, der kan henføres til denne Art; desuden et ganske lille Exemplar bestaaende af Embryonalskallen og en halv Vinding.

Vi har her at gøre med en interessant Skal. Den minder i meget om Skaller, der er henført til Tritonium flandricum DE KoNINCK, men afviger dog paa afgørende Punkter; GRIPP har givet en udmærket Beskrivelse af den. T. enode har en ganske ejendommelig Udvikling i Skallen i de enkelte Intervaller mellem Varices, idet den til at begynde med hvælver relativt stærkt for derefter omtrent ved Midten af Intervallet at aftage i Hvælvethed. Inden den nye Munding anlægges, naar den et Minimum af Hvælvethed og er næsten flad. Hver Gang Skallen vokser frem foran en Varex, begynder den med at anlægge Suturen forholdsvis højt op paa foregaaende Vinding, derefter vandrer den længere ned. I Almindelighed anlægges det første stærkt hvælvede Parti foran en Varex ud for et fladt Parti paa den foregaaende Vinding, saaledes at der til en vis Grad fremskaffes en Udligning: Skallens Akse forbliver ret. Anlægges derimod de hvælvede Partier af Skallen ud for hinanden, bliver Aksen bøjet, og Skallen faar et forkrøblet, krumt Udseende. I sin normale Udformning faar Skallen et buklet Udseende netop som Følge af Intervallernes specielle Udvikling.

Oligocæn: Nordtyskland (ø.).

Miocæn: Nordtyskland (n.).

\section{Familie: Muricidae F1e ming}

Genus: Murex Linné (1758) emend. Lamarck

Subgenus: (Haustellum) KLEIN (1753).

38. Murex (Haustellum) paucispinatus $R$ oth $v$. Te legd

Tavle V, Fig. 17.

1914. Murex (Haustellum) paucispinatus Roth v. Telegd; Ungarn p. 12, t. I, f. $8-10$.

1915. " cfr. Sismondae Bell. Gripp, Altmiocän; p. 34.

1925. " (Haustellum) inornatus Beyr. var. spinifera KaUtsky; Hemmoor; p. 93, t. 7, f. 20. 
Af denne Art er fundet to Skaller, hvoraf det ene er fuldstændig bevaret, Længde: 48,4 mm, Bredde: $23,7 \mathrm{~mm}$ (2:1).

Som nævnt i Beskrivelsen hos Roth v. TeLegd, indtager Skallerne, der tilskrives denne Art, en intermediær Stilling imellem M. Partschi Hoernes og M. spinicosta Bronn.

Skallen adskiller sig fra $M$. Partschi ved ikke at være forsynet med saa mange og lange Torne paa Varices; der kan være udviklet een Torn foroven paa hver Varex. Denne Torn kan imidlertid ogsaa mangle, saaledes at Skallen paa det paagældende Sted kun bærer en særlig spids Knude. Der findes ofte paa Tornens Forside en Slids, der gaar ned til Mundranden. Tornen synes at være bedst udviklet paa de første Mellemvindinger, derimod reduceres den paa de yngste Dele af Skallen.

Slutningsvindingen paa det afbildede Stykke bærer 5 Varices, de første Mellemvindinger har derimod kun tre. Iøvrigt svarer de to fundne Skaller godt til de af Roth v. Telegd og af KaUtsky givne Beskrivelser.

KaUtsky henregner Skaller fra Hemmoor til en Varietet af $M$. inornatus BEYR. og opstiller Varieteten spinifera KAUTSKY, idet han mener at have Overgangsformer mellem disse to. At en Afgrænsning af de til denne Gruppe af Murex hørende Former er ret vanskelig, fremgaar af Litteraturen.

Den af Roth v. Telegd afbildede Skal afviger fra Skallerne fra Klintinghoved ved at have lidt længere Torne.

Miocæn: Nordtyskland (n. m.), Ungarn (Aquitanien).

Subgenus: (Muricantha) Swatnson (1840).

\section{Murex (Muricantha) Deshayesii Nyst}

Tavle VI, Fig. 1.

1845. Murex Deshayesii Nyst; Coqu. et Polyp. foss. de la Belgique; p. 543, t. 41, f. 13.

1854/56. " capito Phil. Beyrich; p. 203, t. 13, f. 4-6.

1854/56. 》D Deshayesii Nyst; Beyrich; p. 206.

1856. " capito Phil. Hoernes I; p. 226, t. 23, f. 10.

1866. "Deshayesii Nyst; Speyer; Cassel; p. 290, t. 32, f. 1-10, 14.

$1872 . " 》$ v. Koenen; Miocän I; p. 147.

1872. " Du Chastel. Koch u. Wiechmann; p. 11.

1907. " Nyst; Ravn; p. 319, t. V, f. 7-8.

$1913 . "$ " " HARDER; p. 76.

1914. " " var. capito Phil. Roth v. Telegd; p. 13, t. III, f. 1.

1914. " " GRIPP; Itzehoe; p. 20, t. II, f. 15-16. 
Af denne Arts ejendommeligt udseende Skal er fundet et stort, smukt Exemplar, hvis Embryonalskal er gaaet tabt, Mundingen er ligeledes beskadiget. Højde: $46 \mathrm{~mm}$, Skallens Diameter ved Mundingen: $26 \mathrm{~mm}$. Desuden er fundet to mere beskadigede mindre Skaller.

Skallerne passer godt til de af GRIPP afbildede Skaller. De afviger fra den af Roth v. Telegd afbildede Skal ved at være betydelig mere slanke.

Oligocæn: Danmark (m.ø.), Nordtyskland (n. m. ø.), Belgien.

Miocæn: Danmark, Nordtyskland (n.), Wiener Bækkenet (1 Medit.) Ungarn (Aquitanien).

Genus: Tiphys Montfort (1810) emend. Agassiz

40. Tiphys horridus B roc chi

Tavle VI, Fig. 2, 3.

1843 (1814). Murex horridus Brocchr; Conchiol. subap. II; p. 194, t. 7, f. 17.

1856. Tiphys pungens Sol. sp. Beyrich; (pro parte) p. 214, t. 14, f. 4-5.

1856. Murex (Tiphys) horridus Brocchi; Hoernes I, p. 260, t. 26, f. 9.

1872. Typhis hortidus Brocchi Bellardi I; p. 69.

1872. Tiphys " " v. Koenen; Miocän I; p. 152.

1874. " " " МørсH; p. 287.

1907. " " "sp. RavN; p. 322.

1914. Typhis " " Rотн v. Telegd; p. 11.

1923. " " " Cossmann et Peyrot; LXXV; p. 236, t. XV,

f. $17-18$.

1925. " " Kautsky; Hemmoor; p. 99.

1936. " " Noszky; Molluskenfauna v. Eger; p. 65.

Der er fundet 2 Fragmenter, det ene bestaar af sidste Vinding med Mundingen, der er lidt beskadiget.

De ældre Forfattere har bestræbt sig for at skelne mellem T. horridus fra miocæne og T.pungens SoL. fra oligocæne Aflejringer. T.pungens udmærker sig ved, at dens Embryonalskal bestaar af $2 \frac{1}{2}$ Vinding, der forneden er forsynet med $\mathrm{K} \varnothing \mathrm{l}$; T. horridus har derimod en Embryonalskal paa 31/4 Vinding uden Køl. De senere Vindinger skal især adskille sig ved, at de hos T. pungens er forsynede med krumme Torne, hvorimod de hos $T$.horridus er lige eller næsten lige. Mundingen er hos $T$. pungens ægformet aflang, hos T.horridus rund.

Miocæn: Danmark (m.ø.), Nordtyskland (n. m. .), Belgien (Anversien), Holland, Vestfrankrig (Burdigalien, Helvétien, Tortonien) Wiener Bækkenet (2 Medit.), Ungarn (Aquitanien) og Italien (Helvétien, Tortonien).

Pliocæn: Italien. 
Familie: Columbellidae Tros che 1

Genus: Atilia H. et A. Adams (1853).

Subgenus: (Macrurella) SACCO (1890).

\section{Atilia (Macrurella) subulata B r oc ch i}

Tavle VI, Fig. 4, 5 .

1856. Columbella subulata Brocchi; Hoernes I; p. 121, t. 11, f. 11. 13.

1880. " fallax Hoernes u. Auinger. I u. II Mediterranstufe p. 96.

1890. " (Tetrastromella) subulata Brocchi; SAcco VI; p. 44, t. 2, f. 49.

1914. " " " Harmer; Pliocene Moll.

Vol. I, p. 56, t. 2, f. $11-12$.

1925. Atilia (Macrurella) " " Kautsky; Hemmoor; p. 101 , t. 7 , f. 28.

Der er fundet 5 mere eller mindre beskadigede Skaller, der er henført til denne Art.

Embryonalskallen er glat, den bestaar af 3 hvælvede Vindinger.

De første Mellemvindinger har til at begynde med brede, flade Tværribber, der ret hurtigt fortaber sig paa de yngste Dele af Skallen, der er glat. Vindingerne er her forholdsvis flade, kun forsynet med Tilvækstskulptur og utydelige, meget fine Spiralfurer.

Mundingen er afrundet rhombeformet og løber ud i en kort Kanal. Paa Yderlæben, der er bevaret paa en af Skallerne, findes seks flade Tænder. Paa Kanalens Yderside findes forholdsvis grove Spiralribber i et Antal af ca 8. Den ene Skal maaler i Højde $6 \mathrm{~mm}$, hvortil svarer en Diameter for sidste Vinding paa 2,5 $\mathrm{mm}$.

Skaller tilhørende denne Art minder en Del om A. attenuata BEYR., hvorfra de især afviger ved, at Mundingen er bredere og rhombeformet; endvidere er sidste Vinding hos A. attenuata mere slank end hos A. subulata.

Miocæn: Nordtyskland (m.), Holland, Vestfrankrig (Helvétien), Wiener Bækkenet (Grunder Sch. 2 Medit.).

Pliocæn: England, Holland, Belgien og Italien.

\section{Familie: Nassidae}

Genus: Nassa La marck (1799).

Subgenus: (Telasco) H. et A. Adams (1853).

42. Nassa (Telasco) Schlotheimi Beyrich

Tavle VI, Fig. 6.

1854/57. Nassa Schlotheimi 1872 .

1872.

1907.
Beyrich; p. 134, t. 7, f. 7-9. v. Koenen; Miocän I; p. 190. Koch u. Wiechmann; p. 33. Ravn; p. 314, t. 5, f. 3. 
1911. Nassa Schlotheimi Beyrich; Koert; Jahrb. d. Preuss. Geol. Landesanst. XXXII, p. 169.

$1913 . \quad " \quad$ " " HARDER; p. 76, t. VI, f. $4-5$,

1914. " " " Gripp; Itzehoe; p. 19, t. II, f. 8-12. $1916 . \quad " \quad "$ NørRegaArd; p. 26.

1925. "(Telasco) Neuvillei Peyrot; Act. Linn. LXXVIII; p. 174, t. III, f. $90-93$.

Der er fundet 10 Skaller, som meget godt svarer til Afbildningerne hos Ravn, Harder og Gripp. Skallerne fra Klintinghoved hører øjensynlig til den butte Varietet (jf. ВечRICH).

De fundne Skaller er interessante ved deres Farvevariationer, der maa anses for at være oprindelige. Farven varierer fra næsten helt hvid til mørkegraa.

Den af Kautsky opstillede N. Schroederi minder i sine fleste Karakterer om N. Schlotheimi. Da denne sidste Form (jf. BEYRICH og GrIPP) varierer meget baade m. H. t. fortykket Munding, Spirets Vinkel, Tænder paa Indersiden af Mundingens Yderlæbe, Skulptur osv., er det et Spørgsmaal, om Kautskys $N$. Schroederi ikke snarere er en Varietet af $N$. Schlotheimi. Den af Peчrot givne Beskrivelse af $N$. Neuvillei viser sammen med Afbildningerne, at der her uden Tvivl er Tale om N. Schlotheimi, idet Peyrot's hele Beskrivelse passer til denne Form.

Oligocæn: Danmark (ø.), Nordtyskland (ø.).

Miocæn: Danmark, Nordtyskland (n. m?), Vestfrankrig (Tortonien).

Familie: Fusidae D'Orbign n (1843).

Genus: Dolicholatyrus Be11ardi (1883).

Subgenus: (Pseudolathyrus) Bellardi (1883).

\section{Dolicholathyrus (Pseudolathyrus) Rothi B e y rich}

Tavle VI, Fig. 7.

1856. Fusus Rothi Beyrich; Conchylien; p. 289, t. 24, f. 1.

1856. " crispus Bonson; Hoennes I, p. 291, t. 32, f. 3.

1872. " " v. Koenen; Miocän I; p. 172.

?1876. Latirus Fornicatus Bellardi; IV, p. 50, t. II, f. 20.

1887. Fusus crispoides Hoennes; Kittl; Ostrau-Karwin; p. 247.

1890. " "Hoernes et Auinger; I u. II Medit. p. 251.

1907. " crispus Borson; Ravn; p. 329. t. VI, f. 10.

1925. Dolicholathyrus (Pseudolathyrus) Rothi Beyr. Kautsky; Hemmoor; p. 115 . t. 8. f. 19.

Der er fundet to Skaller, som mangler Embryonalskal, ellers er de velbevarede; og endvidere to større Brudstykker af Mellemvindinger tilhørende to forskellige Skaller. 
I Overensstemmelse med Hokrnes og Aunnger skiller Kautsky de i Synonymlisten opførte Former fra den pliocæne F. crispus Borson, til hvilken Art GRIPP 1915 (Altmiocän) har henført Skaller fra Sønderborg (= Klintinghoved).

Den karakteristiske Skal udmærker sig ved sin markerede Skulptur, der bestaar af kraftige Tværribber i et Antal af 7-10 for hver Vinding; paa et lidt abnormt udviklet Brudstykke findes endog 13 Ribber. Disse Tværribber krydses af markerede tynde Spiralribber, hvoraf der paa Mellemvindingen findes $3-4$ kraftigere af 1ste Orden. Imellem dem findes indskudt een Spiral af 2den Orden; imellem Spiralerne af 1ste og 2 den Orden atter saadanne af 3die Orden. Mellem øverste Spiral af Iste Orden og Suturen findes et Antal finere Spiraler (3-4 el. flere paa de yngste Vindinger).

Mundingen er ægformet, den bærer paa Yderlæben ca. 10 flade Striber; paa Inderlæben findes ved Mundingens øverste Hjørne en Knude, ved Kanalens Begyndelse to svage Striber, der synes at fortsætte sig et Stykke paa Columella.

Miocæn: Danmark, Nordtyskland (n. m. ø.), Holland, Belgien (Anversien), Wiener Bækkenet (2 Medit.) og Italien (Tortonien).

\section{Genus: Streptochetus Cos s mann (1889).}

44. Streptochetus sexcostatus B ey rich

1856. Fusus sexcostatus Beyrich; Conchylien; p. 287, t. 24, f. 2.

1861. " fasciolaroides Nyst; Bull. de l'Acad. Roy. de Belg. XII; p. 193.

1872. " sexcostatus Beyrich. v. Koenen; Miocän I; p. 40.

1907. " " \# RAvN; p. 331.

1915. " " GRIpp; Altmiocän; p. 34.

1925. Streptochetus sexcostatus" Kautsky; Hemmoor; p. 116, t. 8,

f. $20-21$.

Der er fundet een Skal, hvis Embryonalskal mangler, Kanalen og Mundingen er en Smule beskadiget.

De manglende Partier gør en Bestemmelse vanskelig, idet Skaller af S. sexcostatus og Aquilofusus Waeli Nyst, som nævnt af GRIPP (loc. cit.), minder en Del om hinanden. Den fundne Skal har imidlertid en Kanal, der tydelig er drejet til venstre, hos Aquilofusus er den derimod enten lige eller drejet til højre (KAUtsky 49 p. 119.). Endvidere bærer Skallen kun 8-9 Ribber for hver Vinding; A. Waeli Nyst har et Antal paa 12-16.

Den fundne Skal bærer paa Mellemvindingerne 5 kraftige Spiraler, hvorimellem der kan indskyde sig tyndere Spiraler, i Overensstemmelse med BeYRICHS Beskrivelse.

Miocæn: Danmark (m.), Nordtyskland (n. m.), Holland, Belgien (Anversien). 


\section{Genus: Aquilofusus Kautsky (1925).}

45. Aquilofusus pereger Beyri ch

Tavle VI, Fig. 8.

1856. Fusus pereger Beyrich; Conchylien; p. 271, t. 20, f. $4-5$.

1872. " "

1907. " " RAVN; p. 332.

1915. " " GRIPP; Altmiocän; p. 34.

Til denne Art henføres tre ufuldstændig bevarede Skaller med manglende Embryonalskal samt to Brudstykker.

Skaller af denne Art er ret sjældne. GRIPP nævner den som Ledefossil for nedremiocæne Aflejringer i Nordtyskland.

Miocæn: Danmark, Nordtyskland (n.).

\section{Familie: Cancellariidae H. et A. A d a m s (1853). \\ Genus: Sveltia Jousseaume (1888).}

\section{Sveltia varicosa $\mathrm{Brocch}$ i}

Tavle VI, Fig. 9.

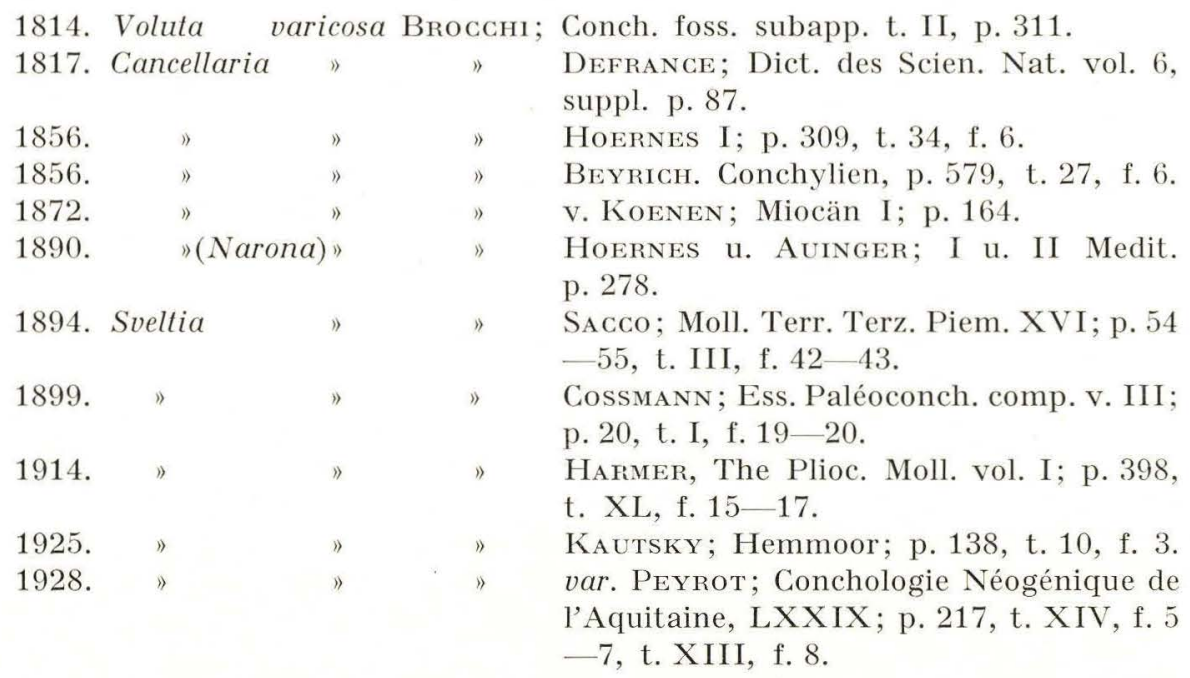

3 velbevarede Skaller samt de to sidste Vindinger af et fjerde Exemplar. Embryonalskallen, bestaar af tre glatte Vindinger.

Paa Mellemvindingerne udvikles hurtigt Ribber og Spiralskulptur. Imellem Spiralribberne findes i Almindelighed ovenfor Vindingernes Midte en særlig kraftig Spiral, hvis Skæring af Ribberne foraarsager Dannelsen af en lille, spids Knude.

Mundingen er pæreformet, spids forneden. Paa Yderlæben findes indvendig smaa, smalle Tænder; paa Columella findes to Folder, der fort- 
sættes ind i Skallen. Navlen er lille, oftest aaben; den kan dog være dækket af Inderlæben.

Skallerne er i god Overensstemmelse med Kautskys Afbildning og slutter sig til den nordtyske Formkreds uden Køl. Sammenlignet med Harmers Afbildninger danner Spiret en større Vinkel, og der findes et større Antal Tværribber for hver Vinding.

Miocæn: Nordtyskland (n. m.), Holland, Belgien (Anversien), Vestfrankrig (var. paucicostata og var. bearnensis: Helvétien; var. simplicior: Tortonien), Wiener Bækkenet (2 Medit.) og Italien (Helvétien).

Pliocæn: England samt Middelhavsomraaderne.

Familie: Conidae $\mathrm{S}$ wa in s on (1840).

Genus: Conus Linné (1758) emend. Lamarck

Subgenus: (Leptoconus) SwaINson (1840).

\section{Conus (Leptoconus) Allionii $\mathrm{Michelotti}$}

Tavle VI, Fig. 10, 11.

1847. Conus Allionii Michelotti. Terr. Mioc. p. 338, t. 17, f. 17.

1872. " " "

1893. " " SACCO XIII; p. 32, t. 4, f. 6.

1907. " " " RAvN; p. 362.

1914. " " " Gripp; Itzehoe; p. 34.

1925. " (Leptoconus) Allionii Michelotti; Kautsky; Hemmoor; p. 146, t. 10 , f. $17-18$.

Der foreligger af denne Art 18 Skaller; kun paa to af Skallerne findes en delvis bevaret Embryonalskal. Det største Exemplar har en Højde paa ca. $30 \mathrm{~mm}$. Diameter: $16 \mathrm{~mm}$.

Efter GRIPP bestaar Embryonalskallen af $5 \frac{1}{2}$ glatte Vindinger. De første Mellemvindinger er paa Skallerne fra Klintinghoveder forsynet med mere eller mindre tydelige Knuder paa Kølen. Tilvækstlinierne skæres paa den over Kølen liggende Del af Vindingerne oftest af meget fine Spiraler. Spirets Udseende kan variere en Del, Vinklen kan være mere eller mindre spids; den ene af de afbildede Skaller er saaledes ret flad, Embryonalskallen hæver sig en Del op over de yngre Dele af Spiret, det andet Exemplar er mere stejlt. Skallens trappeformede Udseende kan endvidere udviskes ved, at Kølen kan være buet.

C. Allionii besidder paa den »lodrette« Del af Slutningsvindingen foroven overordentlig fine Spiraler, forneden findes et Antal kraftigere Spiralfurer.

Skallen af $C$. Allionii minder meget om Conus Semperi Speyer (Speyer; Cassel; p. 4, t. 1, f. 1-5.). Efter Speyer har denne dog en Em- 
bryonalskal paa 4 Vindinger, og endvidere har den en stærkere udviklet Spiralskulptur paa Slutningsvindingen. Den findes i Nordtysklands Mellem- og Øvre-Oligocæn.

Miocæn: Danmark, Nordtyskland (n.m.), Belgien (Anversien) og Italien (Helvétien).

Genus: Genotia H. et A. A d a m s emend. (1853).

48. Genotia trochlearis $\mathrm{Ho}$ ernes

Tavle VI. Fig. 12.

1856. Pleurotoma trochlearis Hoennes I; p. 363, t. 39, f. $14-15$.

1877. Clinura " " Bellardi II; p. 206.

1887. Pleurotoma " " Kittl; Ostrau-Karwin; p. 244.

1891. " (Clinura) " " Hoernes u. Auinger; p. 362.

1903. " " Gotтsche; Neuere Erwerb. d. Mus.,

Verh. d. Nat. Vereins Hamburg (se Gripp 38).

1904. Clinura " " Sacco XXX; p. 49, t. XIII, f. $14-15$.

1915. Pleurotoma " " Gripp; Altmiocän; p. 27, Nr. 182.

1920. " " " GRIpp; Jungtertiär; p. 24.

Af denne særprægede Art er fundet 5 mere eller mindre velbevarede Skaller og desuden en Slutningsvinding.

Paa en af Skallerne er Embryonalskallen bevaret; den bestaar af ca. 3 glatte, hvælvede Vindinger.

Mellemvindingerne er forsynet med en markeret Køl, der ligesom den Del af Vindingen, der ligger under den, bærer tydelige Spiralfurer. Over Kølen ses kun Tilvækstlinier, der fra Kølen bøjer langt tilbage op mod Suturen. Der findes bredere og slankere Skaller, eftersom Suturen anlægges nær op ad Kølen eller lidt længere nede paa foregaaende Vinding. Over Kølen findes en lille flad Rende, der markerer Spiralskulpturens Begrænsning opadtil.

Kølen, der med Undtagelse af den omtalte Spiralskulptur i Almindelighed er glat, kan dog paa de allerførste Mellemvindinger bære Antydninger af smaa Knuder, der dog hurtigt forsvinder længere nede paa Vindingerne. Herved antydes muligvis et Slægtskab med P. Calliope Brocc., hvis Skal efter Hoerses i mange af sine Forhold minder stærkt om den her omtalte Form.

De hos SAcco afbildede Skaller afviger fra Klintinghoved Formerne og Formerne fra Wienerbækkenet ved, at Suturen er anlagt nærmere Kølen, saa Skallen bliver mere buttet.

Til den almindelige Beskrivelse skal desuden knyttes et Par Bemærkninger.

Danmarks Geologiske Undersøgelse, II. R. Nr. 65. 
Det drejer sig om en meget sjælden Form, der i 1856 blev opstillet af Hoennes paa Grundlag af to Skaller fra Wienerbækkenet. Senere omtaler Bellardi den fra Colli torinesi i Italien. Atter betegnes den som meget sjælden; den findes her i Aflejringer, der henføres til Helvétien. I 1903 omtales den i en Liste over Fossiler, indgaaet til Musæet i Hamburg, samlet af Gotтsche og hans Bekendte ved Sønderborg (= Klintinghoved). I sine Betragtninger over Nordsøbækkenets ældste Neogen tager GrIPP denne interessante Form med ind i sine Overvejelser (3\%). Ialt var paa dette Tidspunkt, som Prof. GRIPP venligst har meddelt mig mundtligt, fundet 4 Skaller ved Klintinghoved; heraf opbevares to, samlet af Goтtsche, i det geologiske Institut i Hamburg, de andre to opbevares i Universitetets Geologiske Institut i Kiel.

Foruden de her omtalte Findesteder for G.trochlearis omtales af Hoernes Lapugy i Siebenbürgen.

Ved denne Redegørelses Afslutning skal det understreges, at Undersøgelserne og Litteraturstudierne, der er foretaget i Tilslutning til det ny indsamlede Materiale fra Klintinghoved, fuldt ud bekræfter GoTTsCHE's og GRIPP's Bestemmelser.

Miocæn: Wiener Bækkenet (2 Medit.), Italien (Helvétien), Siebenbürgen, Øvre Schlesien (1 Medit.).

\section{Familie: Pleurotomidae Ghenu (1859). \\ Genus: Surcula H. et A. A da m s (1853).}

\section{Surcula Steinvorthi Semper \\ Tavle VI, Fig. 13.}

1872. Pleurotoma Steinvorthi Semper; v. Koenen; Miocän I; p. 228, t. II, f. 10. 1913. Surcula regularis de Koninck sp. Harder; pro parte, p. 96, t. IX, f. $3-7$. 1914. " " " Rотн v. Telegd; pro parte, p. 21, t. III, f. $10-11$.

1914. Pleurotoma (Surcula) Steinvorthi Semper, Gripp; Itzehoe; p. 29, t. III, f. $8-10$.

1916. " " " Nørregaard; p.33,t.3, f. 10. 1925. Surcula Steinvorthi Semper; Kautsky; Hemmoor; p. 158, t. 11, f. 4.

Der er fundet 18 Skaller, der er lidt defekte paa forskellig Maade; saaledes findes kun to med bevaret Embryonalskal og kun een Skal med Kanal.

Iøvrigt er de i god Overensstemmelse med den citerede Litteratur. Embryonalskallen bestaar ligesom paa Harder's fig. 6 - 7 af 4 glatte Vindinger.

Mellemvindingerne er i Modsætning til S.regularis karakteriserede 
ved ikke at bære Knuder, eller ved kun at bære svage, knudeformede Fremspring paa Kølen paa de første Mellemvindinger.

Tilvækstliniernes Sinus er beliggende lidt over Vindingens Midte i en mere eller mindre udtalt Depression.

Foruden Tilvækstskulpturen findes en Spiralskulptur, der for det meste paa de ældste Vindinger er tydelig; paa de yngste Vindinger kan den blive lidt svagere, især paa Partiet under Depressionen. Paa Slutningsvindingen, der ikke bærer Knuder af nogen Art, er Spiralskulpturen atter kraftigere paa den nederste Del og paa Kanalen.

Spirets Vinkel varierer en Del; Kanalen er omtrent saa lang som den Del af Spiret, der ligger over sidste Vinding.

I de forskellige Karakterer staar denne Skal nær ved S. regularis DE Koninck. Foruden de ovenfor nævnte adskillende Karakterer kan nævnes, at Depressionen paa Vindingerne hos S. regularis ligger højere oppe end hos S. Steinvorthi, idet den opadtil begrænses af Suturen.

De citerede, af HARDER under S.regularis beskrevne Skaller fra det øvreoligocæne Ler ved Aarhus, og de under samme Art af Rотн v. Telegd beskrevne Skaller fra Ungarn, stemmer saa vidt det kan ses saa godt med v. Koenen's Beskrivelse af S. Steinvorthi, at det vil være rigtigst at henføre dem hertil.

Selv om det ligger lidt uden for dette Arbejdes Rammer, skal her ganske kort nævnes, at der er en forbavsende god Overensstemmelse mellem de andre af HaRder og Roth v. Telegd opstillede Varieteter af $S$. regularis DE KonINCK.

Oligocæn: Danmark (ø.).

Miocæn: Danmark (m.), Nordtyskland (n. m. ø.), Holland, Belgien (Boldérien, Anversien), Ungarn (Aquitanien).

Genus: Pleurotoma Lama rck (1798).

Subgenus: Pleurotoma sensu stricto Peyrot (1931).

50. Pleurotoma rotata B r o c chi

Tavle VI, Fig. 14.

1856. Pleurotoma rotata Brocchi; Hoennes I; p. 354, t. 38 , f. 18.

$1877 . "$ " " Bellardi II; p. 13, t. 1 , f. 2.

1879. " " " Hoernes u. Aunger; p. 292.

1914. " coronata Münst. var. lapugyensis Hoenn. et Aung. Roth v. Telegd; p. 18 , t. 1, f. $22-23$.

1925. " rotata Brocchi var. pluridenticulata Kautsky; Hemmoor; p. 160 , t. 11 , f. 7 .

1931. " " var. subrotata D’Orbigny; Peyrot; Act. Linn. LXXXIII; p. 72, t. VIII, f. 81, 83. ?1931. " " " var. peyrerensis Реyrot; Act. Linn. LXXXIII; p. 73 , t. VII, f. $30-31$. 
Til denne Art henføres 9 delvis velbevarede Skaller.

Skallerne, der i Litteraturen bliver opført under denne Art, hører til en Kreds af Former, som staar hinanden nær, men som opføres under talrige Artsnavne; de forskellige Arter er ofte vanskelige at holde adskilte. Da nogen definitiv Bestemmelse i mange Tilfælde ikke kan foretages, skal her gøres nøjere Rede for Exemplarerne fra Klintinghoved.

Skallen er relativ slank. Den bestaar i sin embryonale Del af 2 glatte Vindinger, derefter 2-3 Mellemvindinger med Længderibber, ca. 15 pr. Vinding; bortset fra disse er Skallen glat paa denne Del.

Efter Embryonalskallen følger Mellemvindingerne, der er forsynet med en Køl, Carina, der er omtrent midtstillet paa Vindingerne. Paa Kølen findes en dobbelt Knuderække, hvis Knuder er forbundet ved to. Spiralribber. Knuderne er mere eller mindre spidse.

Paa Slutningsvindingen findes under Carina tre kraftige Spiralribber, mellem dem og ovenfor dem kan der være indskudt finere Spiraler. Over Kølen er der et Antal fine Spiraler, hvoraf den nærmest Suturen er kraftigst.

Suturen følger som Regel den midterste af de tre ovenfor omtalte subcarinale Spiralribber og ligger saaledes imellem to omtrent lige kraftige Ribber, nemlig den øverste subcarinale kraftige Spiral paa foregaaende Vinding og den fremtrædende øverste Ribbe over Kølen paa den følgende Vinding. Suturen kan dog ogsaa anlægges under den midterste grove Spiral under Kølen.

Mundingens Indsnit ligger midt paa Carina. Slutningsvindingen falder ret stejlt ind mod Kanalen.

Kanalen varierer i Længde, men er dog i de fleste Tilfælde af samme Størrelse som Mundingens Diameter fra nederste til øverste Hjørne.

Denne Form staar den oligocæne P. Geinitzi nær, den afviger herfra ved at besidde to Spiraler paa Carina, idet den sidstnævnte har tre. Endvidere synes $P$. rotata at have en til Kanalen stejlere staaende Slutningsvinding.

P.trifasciata, der omtales i det følgende, hører til samme Formkreds, og har ligesom P. Geinitzi tre Spiralribber paa Carina; Slutningsvindingen synes dog at falde stejlere ind mod Kanalen som hos P. rotata.

Endelig skal nævnes den miocæne P. Badensis (= P. rotata RAvN 95 p. 355), der afviger fra alle de andre, ved kun at besidde een Knuderække af rundagtige Knuder, der kan være forbundet med talrige fine Spiraler. Den minder ellers meget om de omtalte Former.

Den fra Ungarn omtalte Skal maa jeg henføre til $P$. rotata, da den fuldstændig svarer til Skallerne fra Klintinghoved.

Miocæn: Vestfrankrig (Aquitanien? Tortonien), Wiener Bækkenet (2 Medit.), Italien (Helvétien, Tortonien), Ungarn (Aquitanien).

Pliocæn: Italien. 
51. Pleurotoma trifasciata $\mathrm{Ho}$ e r n e s

1856. Pleurotoma trifasciata Hoernes I; p. 355, t. 38, f. 17.

1872. " coronata var. trifasciata Hoernes; Koch u. Wiechmann; р. 59.

1878. " subdenticulata Kосн u. Wiechmann; Косн, Pleurotomidae, p. 54.

1879. " trifasciata Hoernes. Hoernes-Auinger; p. 294.

1887. " " " "

1925. " " KAUTSKY;Hemmoor; p. 164,t.11,f.12.

Heraf foreligger 6 Skalbrudstykker.

De er i god Overensstemmelse med Hoknnes' og Kautsky's Afbildninger. De minder i hele deres Habitus om $P$. rotata, som nævnt under denne Art, med Undtagelse af, at de paa Carina bærer tre Spiraler.

I Almindelighed kan det siges, at de adskillende Karakteristika mellem denne Form og de under P. rotata omtalte Former indbyrdes er saa smaa, at man vel kan tænke sig, at det drejer sig om Varieteter af een og samme Art. Det foreliggende Materiale er dog for lille til, at man kan komme til et afgørende Resultat; her skal kun nævnes, at der mellem Skallerne, der er henført til P.rotata, findes et Exemplar, hvis Munding paa et vist Tidspunkt er beskadiget; efter Regeneration af Skallen bærer Carina tre Spiraler som hos Pl. trifasciata og Pl. Geinitzi.

Oligocæn: Nordtyskland (ø.).

Miocæn: Nordtyskland (n. m.), Holland, Øvre Schlesien (1 Medit.), Wiener Bækkenet (2 Medit.), og Italien (Helvétien).

Subgenus: (Hemipleurotoma) Cossmann (1889).

52. Pleurotoma (Hemipleurotoma) Duchastelii N ys t

Tavle VI, Fig. 15.

1863. Pleurotoma Duchastelii Nyst; Sandberger; Mainzer Becken; p. 237, t. 15 , f. 13 .

1867. " " " v. Koenen; Mitteloligocän; p. 38.

1867. " " $"$ Speyer; Cassel; p. 111, t. XV, f. 6-13, t. XVI, f. $1-3$.

1872. " " $"$ v. Koenen; Miocän I; p. 226.

1874. " multicostata DE Koninck; Мørch; p. 296.

1907. " Duchasteli Nyst; Ravn; p. 351, t. 7, ff. 10, 15.

1907. " flexiplicata " " 352.

1913. " Duchasteli " HARDER; p. 94, t. 7, f. 26-37.

1914. " Duchastelli " Roth v. Telegd; p. 17, t. 1, f. 1-3.

1914. " Duchasteli " Gripp; Itzehoe; p. 29.

1916. " " NorregaArd; p. 32, t. 3, f. 9.

1925. " (Hemipleurotoma) Duchasteli Nyst var. flexiplicata KAUTsky; Hemmoor; p. 168, t. 11, f. 21.

1936. $\quad$ \# Duchastelli Nyst; Noszky; Molluskenfauna v. Eger; p. 75. 
Af denne ret almindelige Form er fundet 7 Skaller, der i nogen Grad er beskadigede.

Embryonalskallen, der kan iagttages paa tre Skaller, bestaar foroven af 3 glatte, skinnende Vindinger; herefter følger 11/4 Vinding, forsynet med glatte Ribber, hvorefter Mellemvindingerne begynder.

Den store Variation, der hos denne Form findes m. H. t. Vindingernes Skulptur, er omtalt i de citerede Afhandlinger; de knæbøjede Ribber kan være grove og kan helt forsvinde, og Spiralribberne varierer ligeledes. Skallerne fra Klintinghoved varierer paa samme Maade og svarer iøvrigt til Afbildningerne hos Harder t. 7, f. 32-33 og hos NørRegaArd, Kautsky og Roth v. Telegd; de staar sandsynligvis mellem SPEYER's var. vera og var. multilineata.

Oligocæn: Danmark (m.ø.), Nordtyskland (m. .).

Miocæn: Danmark, Nordtyskland (n. m. ø.), Holland, Belgien (Boldérien, Anversien), Ungarn (Aquitanien).

Genus: Bathytoma Harr. et Burr. (1891).

\section{Bathytoma cataphracta B r oc ch i}

Tavle VI, Fig. 16.

1856. Pleurotoma cataphracta Brocchi; Hoernes I; p. 333, t. 36, f. 5-9.

1872. " turbida Solander; v. Koenen; Miocän I; p. 215.

1877. " cataphracta Brocchi; Bellardi II; p 230, t. 7, f. 20.

1904. Bathytoma cataphracta BrocchI; SAcco XXX, p. 50, t. XIII, f. 21-22.

1907. Pleurotoma subdenticulata v. Münster; Ravn; p. 350, t. 7, f. 14 .

1907. " cataphracta Brocchi; Ravn; p. 350, t. 7, f. 12.

1913. Dolichotoma " " sp. Harder; p. 99, t. 9, f. 16.

1913. " " " var. " p. 100, t. 9, f. 17.

$1913 . \quad " \quad s u b d e n t i c u l a t a$ v. Münster $s p$. Harder; p. 100, t. 9, f. $18-22$.

1914. Bathytoma cataphracta Brocchi var. humilis Roth v. Telegd; p. 23, t. 1, f. 28.

1914. Pleurotoma (Dolichotoma) turbida Sol. Gripp: Itzehoe; p. 28.

1925. Bathytoma cataphracta Brocchi; Kautsky; Hemmoor; p. 179, t. 11, f. 33 .

\begin{tabular}{|c|c|c|c|c|}
\hline 1932. & ") & $"$ & " & var. PEyrot; Act. Linn. LXXIV; p. \\
\hline & 》) & $»$ & " & Noszky; Eger; p. 79. \\
\hline
\end{tabular}

8 Skaller, een med Embryonalskal.

Som ved saa mange andre Arter indenfor Pleurotomidae drejer det sig ogsaa her om en stærkt varierende Art, der har givet Stødet til Oprettelsen af nye Varieteter og Arter, saa meget mere, som den synes at forekomme gennem en stor Del af Tertiæret.

Embryonalskallen bestaar af ca. 3 Vindinger, hvoraf den sidste $3 / 4$ Vinding bærer glatte Ribber; den øverste Del er derimod glat.

Spirets Vinkel varierer en Del, hvilket hænger sammen med Suturens Beliggenhed, idet den kan anlægges nær Kølen eller et Stykke neden- 
for denne. I første Tilfælde faas forholdsvis brede Former med relativ stor Vinkel for Spiret, i andet Tilfælde faas de slanke Former.

Skulpturen varierer ligeledes stærkt og kan for Knudernes Vedkommende næsten helt forsvinde paa Carina.

Den største af Skallerne svarer godt til Dolichotoma subdenticulata hos Harder (loc. cit. t. IX, f. 18.).

Det er et Spørgsmaal, om man ikke, som GRIPP og andre Forfattere, bør henregne cataphracta-Formkredsen til turbida-Formkredsen med Bathytoma turbida Sol. som Type; denne sidste findes i Oligocænet og Felt tilbage til Eocænet. KaUtsky bestræber sig for at holde de to hormkredse adskilte. Endnu maa man dog sige, at Problemet ikke er endelig løst.

Oligocæn: Danmark (m.ø.), Tyskland (?).

Miocæn: Danmark (m. ø.), Nordtyskland (n. m. ø.), Holland, Belgien (Boldérien, Anversien), Vestfrankrig (Aquitanien, Burdigalien, Helvétien, Tortonien), Wiener Bækkenet (Grunder Sch. 2 Medit.), Italien (Helvétien, Tortonien). Ungarn (Aquitanien).

Pliocæn: Middelhavsomraaderne.

Genus: Drillia Gray (1838).

Subgenus: (Cymatosyrinx) DALL (1889).

54. Drillia (Cymatosyrinx) Selenkae v. Koenen Tavle VI, Fig. 17.

1872. Pleurotoma Selenkae v. Koenen; Miocän I; p. 241, t. 3, f. 4.

1904. Drillia Selenkae v. Koenen; Sacco XXX; p. 46, t. 12, f. $39-40$.

1925. Drillia (Cymatosyrinx) Selenkae v. Koenen; Kautsky; Hemmoor; p. 176, t. 11 , f. 29.

Til denne Art henføres to Skaller, der begge mangler Embryonalskal, og som begge har en beskadiget Munding.

Skallerne svarer iøvrigt til v. Kownen's og Kautskys Beskrivelser og Affbildninger, men er lidt mere slanke.

Efter v. Koenen staar denne Form den miocæne P. Suessii fra Wiener Bækkenet og den øvreoligocæne P. Koeneni nær (Hoernes; Wiener Becken I; p. 384, t. 40, f. 13 et Speyer; Cassel; p. 124, t. 17, f. 6-7). Efter samme Forfatter adskiller de tre Former sig fra hinanden ved følgende:

P. (Drillia) Suessii har 3 embryonale Vindinger, og Mellemvindingerne har skraa Ribber; D. Selenkae har derimod 11/2 Embryonalvindinger og spidse Knuder paa de efterfølgende Mellemvindinger; P. (Drillia) Koeneni endelig har ligeledes 1/2/2 embryonale Vindinger, men ensartede, rundagtige, skraa Ribber paa Mellemvindingerne.

KAUTSKY gør opmærksom paa, at der muligvis findes Tilknytning 
til Drillia limatula Conrad var. pyramidalis Martin fra St. Marys Formation, øverste Del af Miocænet i Maryland (Maryland p. 169, t. XLII, fig. 16.); Skallerne fra Klintinghoved er dog betydelig slankere end den omtalte fra Maryland.

Miocæn: Nordtyskland (n. m.), Holland, Vestfrankrig (Tortonien), Italien (Tortonien).

Genus: Daphnella Hinds (1844).

Subgenus: (Raphitoma) BELLARDI (1847).

55. Daphnella (Raphitoma) Roemeri Phil. sp. Tavle VI, Fig. 18.

1867. Mangelia Roemeri PhiL. sp. v. Konnen; Mitteloligocän; p. 95, t. 6, f. 9. 1870. " " " Speyer; Cassel; p. 122, t. 16, f. 13, t. 17, $\begin{array}{ll}1872 . ~ & \text { f. } 1-5 . \\ 18 \text { v. Koenen; Miocän I; p. } 247 .\end{array}$

1872. " "

1914. Raphitoma " " "GrIPP; Itzehoe; p. 32.

1925. Daphnella (Raphitoma) mio Roemeri Kautsky; Hemmoor; p. 186, t. 12, f. 12 .

Der er fundet en næsten fuldstændig bevaret Skal (Mundingen er dog beskadiget) endvidere et større Skalfragment, hvor Mundingen og Embryonalskallen mangler. Højden for den hele Skal: 10,4 mm, Diameter: $4,7 \mathrm{~mm}$.

Bemærkelsesværdigt er det, at der paa Embryonalskallen kan iagttages en fin Krydsskulptur. Det drejer sig muligvis her om samme Skulptur, som er omtalt af v. Koenen (Miocän I; p. 247). Der sigtes til den af denne Forfatter omtalte Skulptur paa sidste Embryonalvinding, som skulde bestaa af Tværribber og Spiralribber, der efter v. Koenen optræder paa sidste Vinding. Skallen fra Klintinghoved viser imidlertid diagonalt stillede Striber, to Systemer, der skærer hinanden, derimod findes ikke Spiral- eller Tværribber paa Embryonalskallen. Krydsskulpturen findes øjensynlig paa alle Embryonalskallens ca. 31/2 Vindinger.

Mellemvindingerne er ved en Kant delt i to Partier, hvoraf det øverste, der er den Del af Vindingen, hvor Tilvækstliniernes Sinus befinder sig, er næsten glat; den er kun forsynet med Tilvækstlinierne og en fin Spiralstribning. Paa Vindingernes nedre Del findes let bøjede Tværribber, hvis Antal kan variere meget (10-20 pr. Vinding); paa de yngste Vindinger kan de næsten forsvinde. Hele Skallen er forsynet med en fin Spiralskulptur.

KaUtsky har forsøgt at skille de miocæne Former fra de oligocæne. Da hans Diagnose udelukkende baseres paa saa varierende en Del af 
Skallen som Tværribberne og den af dem dannede Kant paa Vindingerne, mener jeg ikke at kunne tiltræde Oprettelsen af den nye Art, da de nævnte Forskelle forekommer mig at være for utilstrækkelige til at berettige et saadant Skridt.

Oligocæn: Nordtyskland (m. ø.).

Miocæn: Nordtyskland (n. m.).

B. Opisthobranchia M. Edw. (1848).

Familie: Ringiculidae $\mathrm{F}$ is che $\mathrm{r}$ (1883).

Genus: Ringicula Deshayes (1838).

56. Ringicula sp.

Der er fundet en meget fragmentarisk Slutningsvinding af en Skal tilhørende denne Slægt.

\section{Familie: Scaphandridae F is cher (1883). \\ Genus: Scaphander Montfort (1810).}

57. Scaphander lignarius L. var. Grateloupi $\mathbf{M}$ i $\mathbf{c h}$.

Tavle VI, Fig. 19.

1856. Bulla lignaria L. Hoernes I; p. 616, t. 50, f. 1.

1882. Scaphander lignarius L. var. Grateloupi Mrch. v. Koenen; Miocän II; p. 347 .

\begin{tabular}{|c|c|c|c|c|c|c|c|}
\hline 1897. & $"$ & ") & ") & " & 》) & $»$ & $\begin{array}{l}\text { SACCO; XXII; p. } 44 \text {, t. } \\
3 \text {, f. } 104-112 .\end{array}$ \\
\hline 1907. & $\gg$ & 》 & 》) & " & $\gg$ & " & Ravn; p. 368. \\
\hline 1914. & » & 1) & (1) & " & " & " & Gripp; Itzehoe; p. 36. \\
\hline 1925. & $»$ & ") & त) & » & 》 & $»$ & $\begin{array}{l}\text { KAUTSKY; Hemmoor; } \\
\text { p. } 198 .\end{array}$ \\
\hline 1932. & ») & 1) & 1) & " & 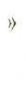 & ") & $\begin{array}{l}\text { PEyrot; LXXXIV; p. } \\
202 \text {, t. XII, f. } 15,17 \\
21 .\end{array}$ \\
\hline
\end{tabular}

Heraf er fundet 2 velbevarede Skaller samt to lidt defekte Stykker. Den ene Skal maaler: Længde $23,7 \mathrm{~mm}$, Bredde $13,4 \mathrm{~mm}$; den anden: Længde 23,8 mm, Bredde 14,0 mm. De to Forhold bliver da som 1,8:1 og 1,7:1 og svarer saaledes godt til de af v. KoEnex givne Størrelser for nordtyske Former.

Miocæn: Danmark (m.ø.), Nordtyskland (n.m.ø.), Holland, Belgien, Vestfrankrig (Aquitanien, Burdigalien, Helvétien), Wiener Bækkenet (Grunder Sch. 2 Medit.), Italien (Helvétien). 
Familie: Bullidae La marck (1822).

Genus: Bullinella Newton (1891).

58. Bulinella cylindracea P e n n.

Tavle VI, Fig. 20.

1848. Bulla cylindracea Penn. Wood; Crag Moll. I; p. 175, t. 21, f. 1.

1856. " convoluta Brocc. Hoernes I; p. 623, t. 50, f. 7.

1882. Cylichna cylindracea Penn. v. Koenen; Miocän II; p. 345.

1897. Bulla " (var. convoluta) SAcco XII; p. 49, t. 4, f. 8-10.

1907. Cylichna " Penn. sp. Ravn; p. 367, t. 8, f. 15.

1914. " " " Gripp; Itzehoe; p. 36.

1925. Bullinella " " Kautsky; Hemmoor; p. 198.

7 Skaller, hvoraf 2 meget smukt bevarede Stykker. Det største Exemplar maaler: Højde 6,4 mm; Diameter $3,4 \mathrm{~mm}$.

De fundne Skaller svarer godt til Ravns Beskrivelse; derimod findes ikke, som nævnt af GrIPP, nogen Navle paa nogen af Skallerne. Efter v. Koenen findes Navlen især hos korte, brede Former, derimod ikke hos lange, slanke Skaller.

Oligocæn: Nordtyskland (n. m. ø.).

Miocæn: Danmark (m.ø.), Nordtyskland (n.m.ø.), Holland, Belgien, Vestfrankrig (Burdigalien, Helvétien), Wiener Bækkenet (2 Medit.) og Italien (Helvétien, Tortonien).

Pliocæn: England, Belgien, Italien.

Recent: Atlanterhavet (England) og Middelhavet.

59. Bullinella Seebachii v. K o e ne n

Tavle VI, Fig. 21.

1867. Bulla (Cylichna) Seebachii v. Koenen; Mitteloligocän; p.71, t. II, f. 15 .

En Skal med Højde 6,2 $\mathrm{mm}$ og Diameter 3,5 $\mathrm{mm}$ henregnes til denne Art.

Skallens Omrids er ellipsoidisk. Overfladen er forsynet med en Skulptur af fine Spiralfurer, der ligger tættest øverst og nederst paa Skallen, hvor de ogsaa er dybest. Paa Skallens Midtparti findes ca. 10-11 Furer pr. mm.

Den øvre Navleaabning er næsten helt lukket, kun en punktformet Perforation antyder den. En nedre Navleaabning findes ikke hos denne Skal i Modsætning til, hvad der er omtalt af v. Koenen.

Med Undtagelse af denne sidste Uoverensstemmelse svarer Skallen til Beskrivelse og Afbildning hos v. Koenex.

Oligocæn: Nordtyskland (m.).

Genus: Roxania Leach (1848).

60. Roxania utriculus B roc chi

1843. (1814). Bulla utriculus Brocchi; Conchiol. Subapp. II; p. 463, t. 1, f. 6. 1845. Bulla utricula Brocchi; Nyst; Coqu. et Polyp. foss. de la Belgique; p. 457. 
1856. Bulla utricula Brocchi; Hoernes I; p. 618, t. 50, f. 2.

1870. " " "Speyer; Cassel; p. 177, t. 19, f. $5-6$.

1874. " (Roxanias) utriculus Brocсні; Мøгсн; Forst. i Tertiærlag, p. 284.

1882. " utriculus Brocchi; v. Koenen; Miocän II; p. 338.

1887. " utricula M. Hoennes; Kittl; Ostrau Karwin; p. 239.

1907. Atys utriculus Brocchi sp. Ravn; p. 367, t. 8, f. 13.

1913. " " " HARDER; p. 103, t. 9, f. 26.

1914. " " Gripp; Itzehoe; p. 35.

1916. " " " sp. Nørregatrd; p. 36.

1925. Roxania utriculus " KaUtsky; Hemmoor; p. 200.

Af denne Art er fundet en velbevaret Skal, Højde: 4,3 mm, Diameter: 2,8 $\mathrm{mm}$. Den er i god Overensstemmelse med Afbildninger hos SPEYER, Ravn og Harder. Som nævnt af tidligere Forfattere staar den den nedreoligocæne $R$. Clara nær (v. KoEnex, 63 p. 951, t. 59, f. 29).

Oligocæn: Danmark (ø.), Nordtyskland (m. ø.).

Miocæn: Danmark (m.ø.), Nordtyskland (n.m.ø.), Holland, Belgien (Anversien), Vestfrankrig (Burgigalien, Helvétien, Tortonien), Wiener Bækkenet (2 Medit.), og Italien (Tortonien).

Pliocæn: Belgien, Italien.

Recent: Atlanterhavet fra Norge til Madeira, Middelhavet.

\section{Familie: Actaeonidae Fis cher (1883). \\ Genus: Actaeon Montfort (1810). \\ 61. Actaeon Philippi K o ch sp.}

1871. Actaeon Philippi Koch; Speyer, Cassel; p. 264, t. 34, f. $1-3$.

1907. " " sp. RAVN; p. 363.

1914. " " " GRIPP, Itzehoe; p. 35.

Til denne Art henregnes et temmelig beskadiget Stykke (Mundingen er ødelagt). Iøvrigt passer Skallen til Speyers Beskrivelse.

Oligocæn: Danmark (ø.), Nordtyskland (m?ø.).

Miocæn: Nordtyskland (n.).

\section{Pteropoda Cuvier (1804).}

\section{Familie: Limacinidae Gray}

Genus: Spirialis Eydoux et Sou1eyet (1840).

62. Spirialis stenomphalus Gripp sp.

1912. Spirialis stenomphalus Gripp; E. Koch, K. Gripp u. A. Franke. Die staatlichen Tiefbohrungen etc. p. 24, f. $5-7$. 
Der er fundet 4 glatte Skaller tilhørende Slægten Spirialis. Skallen er perlemorsagtig og bestaar af 3-4 Vindinger. Mundingen er beskadiget paa alle Stykkerne og kan saaledes ikke beskrives; paa en af Skallerne kunde dog iagttages en lille, tilbagebleven Del af Mundingen med den karakteristiske tilbagebøjede Kant.

Spirets Højde varierer en Del, saaledes at Skallerne maaske nærmest maa siges at staa imellem S. stenomphalus og den af v. KoEnEN omtalte Spirialis dilatata (v. Koenen; 63, p. 994, t. LXII, f. 5-6). Dette kunde tyde paa, at de to Former repræsenterer Varieteter af samme Art.

Suturen ligger forholdsvis dybt; i Nærheden af den iagttages Skallens Tilvækststriber bedst. Navlen er meget snæver. Den ene af Skallerne, der nærmer sig S. stenomphalus mest, som den er afbildet hos GRIPP, maaler i Højde ca. 1,4 mm, Bredde 0,9 mm.

Oligocæn: Nordtyskland (m).

\section{Familie: Cavoliniidae D'O r b ig n y (1837). \\ Genus: Vaginella Daudin (1802).}

\section{Vaginella depressa $D$ a u d in}

1825. Vaginella depressa Daudin; Basterot; Bordeaux I; p. 19, t. 4, f. 16.

1856

1874

1883.

1886.

1907.

1913.

$1916 . \quad "$

1925.

1933.
Hoernes I; p. 663, t. 50, f. 42.

Mørсн; Forsteninger i Tert. Lag; p. 285.

v. Koenen; Miocän II; p. 355.

Kittl; Miocäne Pteropoden; p. 57, t. II,

f. $17-22$.

Ravn; p. 369, t. VIII, f. 17.

HARDER; p. 103, t. IX, f. 28.

Nørregaard; p. 37.

var. austriaca Kittl; KaUtsky; Hemmoor; p. 203.

Peyrot; Act. Linn. LXXXV; p. 22, t. XVIII, f. $36-37$.

Heraf er kun fundet to Skaller; den ene er ret fragmentarisk og sidder paa en Stenkærne.

Iøvrigt svarer Skallerne til Beskrivelser og Afbildninger hos HoERnes, v. Koenen og Ravn. Det af Harder afbildede Exemplar afviger ved sin større Slankhed og ved Skallens bøjede Form.

Til den almindelige Beskrivelse er for Klintinghoved Skallernes Vedkommende kun det at tilføje, at den paa hver Side bærer en lille Køl, der løber fra Skallens Spids til Skallens Midte, hvor den taber sig.

$V$. depressa synes at variere meget i Udseende; der findes korte, tykke og lange, slanke Former imellem hinanden. Hvorledes disse Former forholder sig til hinanden kan endnu ikke siges at være klarlagt. 
Oligocæn: Danmark (ø.).

Miocæn: Danmark (m.ø.), Nordtyskland (n. m.ø.), Holland, Belgien (Anversien), Vestfrankrig (Aquitanien, Burdigalien, Helvétien), Øvre Schlesien (1 Medit.), Wiener Bækkenet (2 Medit.) og Italien (Helvétien).

\section{Crustacea.}

\section{Catametopa Milne Edwards}

\section{Familie: Carcinoplacidae Ortman n}

Genus: Coeloma Milne Edwards (1865).

64. Coeloma incarinatum nov. sp.

Tavle VII, Fig. 1-3, Tavle VIII, Fig. $1-3$,

Der er fundet en Del velbevarede Crustacélevninger omfattende 3 Cephalothoraces, 1 Sternum med Rester af Lemmerne samt et Antal mere eller mindre velbevarede Brudstykker, især af Klosakse.

Disse Fossiler kan med Sikkerhed henføres til Krabber af Slægten Coeloma, uden at det dog er muligt at henføre dem til nogen af de hidtil beskrevne Arter. Derfor skal de her beskrives under et nyt Artsnavn, Coeloma incarinatum nov. sp., idet der med dette Navn ønskes givet Udtryk for en af de væsentlige Forskelle mellem denne nye Art og den i mange Forhold lignende C. bicarinatum, opstillet af RAvN 1903.

Det bedst bevarede Cephalothorax, (forøvigt det eneste af de tre fundne, der har tilhørt et hunligt Individ) maaler fra Pande til Bagrand ca. $25 \mathrm{~mm}$ ) Afstanden fra Epigastrallobernes forreste Del til Pandetornenes Spids er ca. $3 \mathrm{~mm}$. Skjoldets Bredde maalt mellem de to sidste Torne paa Anterolateralranden er ca. $31 \mathrm{~mm}$, Anterolateralranden er ca. 9,8 mm, Posterolateralranden ca. $13,8 \mathrm{~mm}$, og Frontalbredden maalt mellem de to første Torne, der markerer Begyndelsen af Anterolateralrandene, er $21 \mathrm{~mm}$. Da det er vanskeligt at maale Bagranden paa eentydig Maade, gives her i Stedet for Afstanden mellem de to Posterolateralrandes bageste Afslutning, hvorved man faar et godt Maal for Bagrandens Bredde. Denne Afstand er ca. $21 \mathrm{~mm}$ og viser sig saaledes at være nøjagtig af samme Længde som den omtalte Frontalbredde.

Vi skal nu gaa over til Beskrivelsen af Cephalothorax i Almindelighed.

Pandepartiets Forrand bærer nærmest Midterlinien to tæatsiddende smaa Torne. Til højre og venstre for dem sidder i deres dobbelte Afstand en lidt mindre Torn, hvorefter Randen trækker sig tilbage for i en Bue at gaa over i Supraorbitalranden, der har to smaa Indsnit, et 
omtrent midt paa Orbitalranden, det andet tæt op ad første Sidetorn, der markerer Begyndelsen af margo anterolateralis.

Margo anterolateralis bærer i sin typiske Udvikling 5 spidse Torne, hvis Spidser alle peger fremefter. Nummereres disse Torne forfra med Numrene 1-5, er Nr. 5 den længste, derefter følger 1, 3, 4 og 2 . Nr. 2 kan være meget svagt udviklet, saaledes at Skjoldet i saa Tilfælde med nogen Ret kan siges kun at have 4 Sidetorne paa Anterolateralranden.

Margo posterolateralis danner en næsten ret Linie, hvis Længde forholder sig til Anterolateralrandens som et Forhold af en Størrelsesorden mellem $3: 2$ og $4: 3$.

Margo posterolateralis har bagest paa hver Side et svagt buet Indsnit til det sidste Par Ben. Bagranden er praktisk talt lige, kun ganske svagt konvex.

Skjoldets Overside er forholdsvis kraftig lobuleret. Som nævnt ovenfor findes ca. $3 \mathrm{~mm}$ fra Pandetornenes Spids de to smaa aflange, transversalt stillede Epigastrallober; bagved dem følger de store runde Protogastrallober, der til Siden naar ud til et Punkt lodret under Midtpunktet mellem de omtalte Indsnit paa Supraorbitalranden. Mellem Protogastralloberne sender Mesogastralloben en lang tynd Udløber frem, der naar op paa Højde med Protogastrallobernes forreste Begrænsning. Mesogastrallobens Hovedparti har omtrent Form som en i Forhold til Skjoldets Midtlinie diagonalt stillet, ligesidet Rhombe. Lige bag ved denne slutter lobus urogastricus op som en tofliget Lobe, skilt fra Mesogastralloben ved to Rækker af Ar-lignende Granulationer, der af NoETLING tydes som Ar efter Fasthæftningssteder af Muskler, en Forklaring, der, saa vidt vides, endnu ikke er blevet bekræftet af andre.

Sulcus cervicalis kan paa to af Skjoldene iagttages som en svag Fure, der tager sit Udspring mellem 3.og 4. Torn paa Anterolateralranden, den bøjer lidt tilbage, gaar derefter atter frem for saa i en Bue at glide ned langs med Meso- og Urogastrallobernes laterale Begrænsning. Den kan derefter ikke spores længere.

Sulcus cervicalis danner forreste Begrænsning af lobus anterobranchialis. Denne Lobe danner et S-formet Parti i Skjoldets Overflade $o g$ skilles fra lobus posterobranchialis ved en svag Fure, der træffer Skjoldets Rand netop saa langt bagved Torn Nr. 5, som Mellemrummet mellem 3die og 4de Sidetorn ligger foran den. Mod Skjoldets Midte begrænser den meso- og urogastrale Del af sulcus cervicalis Anterobranchialloben. Det er ret vanskeligt indenfor lobus anterobranchialis at afgrænse exo-, meso- og ento-Regionerne. Exo-Regionen ligger foran 5te Torn og er ret fladt nedsænket i Forhold til den bagved liggende kølede meso-Region. Denne sidste skilles fra ento-Regionen ved en meget svag Fure. 
I Posterobranchialloben er det umuligt at skelne mellem de tre Underafdelinger. Bemærkelsesværdigt er det, at man hos denne Art som hos andre af Slægten finder to bagved hinanden liggende Knuder paa denne Lobe.

Cardiacalregionen skilles fra lobus urogastricus ved et sadelformet Parti; paa den findes tre Knuder ordnet i Trekant, to foran, een bagved. Paa det ene Exemplar findes de to forreste Knuder forbundet ved en Tværvulst.

Foruden de omtalte Knuder findes paa det hunlige Exemplar mere uregelmæssigt fordelte, ret grove Granulae rundt omkring paa Skjoldets Overside; de to andre Skjolde er mere glatte.

Skjoldets Bagrand er næsten lige, kun ganske lidt konvex, i Modsætning til den mellemoligocæne Coeloma holsaticum, hvis Bagrand er svagt konkav.

Flankerne forholder sig som hos C.holsaticum og C. bicarinatum; de støder op til Anterolateralranden under en spids Vinkel, til Posterolateralranden under en Vinkel paa $90^{\circ}$ eller mere.

Af de Dele, der begrænser Mundaabningen, er paa et af Stykkerne bevaret Epistomet, der er udviklet paa samme Maade som hos $C$. holsaticum og C. bicarinatum. Endvidere kan ses Aftryk efter Endostomet, der ikke er bevaret; det synes dog at have haft samme Udvikling som det hos C. holsaticum beskrevne, derimod har Branchiostegitens indre Rand et Forløb afvigende fra, hvad der er Tilfældet hos denne Form, idet den Del af Randen, der lateralt afgrænser Mundaabningen ikke er parallel med det tilsvarende Stykke paa den modsatte Side (se SToLleY t. VI, f. 1 a.), men derimod danner en spids Vinkel med det, saaledes at de to Stykker konvergerer bagud.

Branchiostegitens Rand bøjer brat af under en Vinkel paa ca. $90^{\circ}$ netop ud for den forreste Spids af plastron sternale og faar derved en Retning ud mod Skjoldets Rand. Denne Del af Branchiostegitens Rand danner forlænget fremefter en stump Vinkel med det tilsvarende Stykke paa den anden Halvdel af Skjoldet, Vinkelen er ca. $165^{\circ}$ eller mere. Der viser sig altsaa atter her en karakteristisk Forskel sammenlignet med $C$. holsaticum, hvor de to Stykker ligger paa en ret Linie, vinkelret paa Medianplanet.

De her skildrede Dele af Skjoldets Underside kan paa de af RAvN beskrevne og afbildede Stykker af C. bicarinatum kun ses daarligt bevaret paa Exemplaret, der er afbildet paa t. V, f. 5. (RAvN 1903). Det synes som om Branchiostegitens indre Rand forholder sig ganske paa samme Maade som hos C. incarinatum.

Sammenlignes Størrelsesforholdet mellem Branchiostegit og Flanke hos $C$. incarinatum med de tilsvarende Dele hos $C$. holsaticum, viser det sig, at Flanken er forholdsvis større hos $C$. incarinatum end hos den sidste Form. 
Plastron sternale bestaar af 5 Sterniter og maa siges at være udviklet ganske paa samme Maade som hos C. bicarinatum, hvorfor vi ikke her skal komme ind paa det. Det hanlige Abdomen er udviklet som hos C.bicarinatum, det hunlige synes derimod at være mere afrundet end hos denne Form, dog ikke saa stærkt som hos STOLLEY's Afbildning t. V, f. 1, c. af det hunlige Abdomen hos C. holsaticum. De enkelte hunlige Abdominalled begrænses fortil af en konvex Linie, bagtil af en konkav, hvorved $C$. incarinatum slutter sig til $C$. bicarinatum, men staar i Modsætning til C.holsaticum, hvor disse Linier er parallele.

Af Lemmerne er bevaret sidste Kæbefod med samme Udformning som hos C.bicarinatum endvidere venstre Klosaks, hvor de to sidste Led er en Del beskadiget, samt de tre første Led af den efterfølgende Pareiopod. Da disse Dele ikke frembryder noget væsensforskelligt sammenlignet med $C$. bicarinatum skal de ikke omtales nærmere.

Nedenfor sammenstilles de adskillende Karakterer for følgende Arter, der udvikler en vis Lighed indbyrdes, idet de i Modsætning til de andre i Litteraturen beskrevne Arter af Slægten Coeloma har fem Torne paa Anterolateralranden ${ }^{1}$ ); disse Arter er: Coeloma rupeliense StaInier, Coeloma holsaticum Stolley, Coeloma bicarinatum Ravn og Coeloma incarinatum nov. sp.

C. bicarinatum og incarinatum slutter sig sammen i de fleste Karakterer; det væsentligste Middel til deres Adskillelse ligger i de to kraftige Køle, som paa Posterobranchialloberne findes hos den første, men ikke hos den sidste (se Tavlerne VII og VIII)²).

Fra $C$.holsaticum afviger $C$. incarinatum for det første derved, at Tornene paa Anterolateralranden ikke som hos hin Form radierer ud fra et "Centrum«, beliggende omtrent i Berøringsomraadet mellem lobus protogastricus og lobus anterobranchialis; men de er derimod alle fem rettet fremefter. Forranden danner en mindre Vinkel med Anterolateralranden (omkring $100^{\circ}$, C.holsaticum: $120^{\circ}$ ), Bagranden er lige. Som Følge af det anførte har $C$. incarinatum et mere trapezoidisk Udseende end $C$.holsaticum. Forskellene viser sig ogsaa tydeligt ved en Sammenligning af Undersiden: Branchiostegiternes indenfor Mundfeltet beliggende Rand er ikke parallele som hos C.holsaticum, men konvergerer bagud, det hunlige Abdomen er mere spidst, dets enkelte Led begrænses fortil af en konvex, bagtil af en konkav Linie, ikke af parallele Linier.

Fra $C$.rupeliense, hvor det kun har været muligt at sammenligne med

1) De ovrige Arter besidder kun fire Torne. De hidtil beskrevne Arter findes anfort hos F. Lörenthey 1929 p. 241.

$\left.{ }^{2}\right)$ Der kan findes smaa Tilløb til en Slags Køle, som dog ikke bliver tilnærmelsesvis saa kraftige som hos C. bicarinatum, og som i saa Tilfælde divergerer fremefter og ikke bagud som hos denne. 
den af Stolley givne Tegning af Stamniers Afbildning, synes $C$. incarinatum at afvige først og fremmest ved, at Tornene ikke radierer, men viser fremefter. Endvidere er det her Torn Nr. 2 paa Anterolateralranden og ikke som hos C. rupeliense Nr. 4, der er den svagest udviklede. Øjensynlig er ogsaa Forskellen mellem de to Formers Pandeparti, det er længst hos $C$. rupeliense, hvorved denne Form ogsaa skiller sig ud fra C.holsaticum. C. incarinatum bærer endvidere Pandens Sidetorne netop paa det Sted, hvor Randen bøjer tilbage i Supraorbitalranden, hvorimod denne Torn hos C.rupeliense er rykket Medianlinien nærmere, saaledes at der dannes en lille "Afsats«, inden Forranden gaar over i Supraorbitalranden. Posterolateralranden og Bagranden er lige, hvorimod de tilsvarende Dele hos C.rupeliense er. henholdsvis konvexe og konkave. En Fortsættelse af sulcus cervicalis paa Flankerne, som STOLLEY omtaler hos C. rupeliense, findes ikke hos C. incarinatum. 


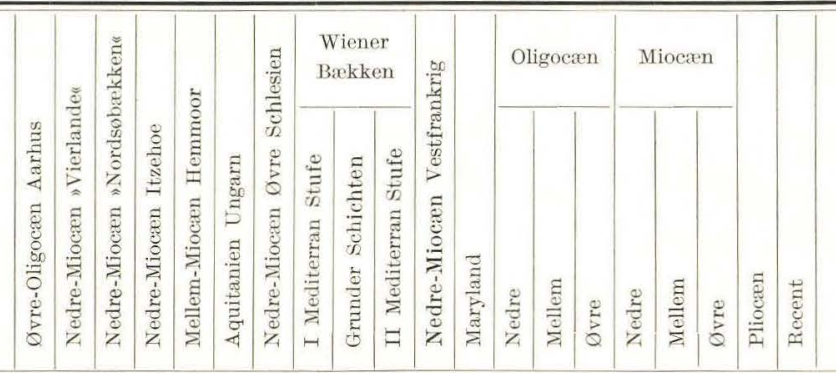

1. Lissochlamys cfr. Gérardi Nyst... . . . . . . . . . . . . . . . . + + + $+\ldots 1$

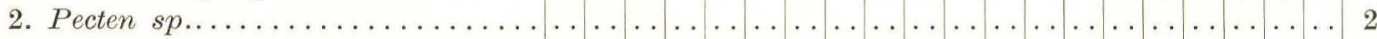

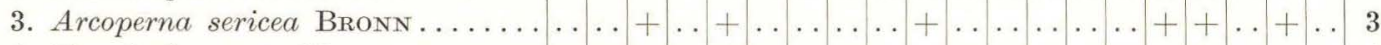

4. Nucula hanseata Kautsky....... $\ldots \times \ldots+\ldots \ldots \ldots \ldots \ldots \ldots \ldots \ldots \ldots \ldots$

5. Nucula nucleus L. var. Hanleyi

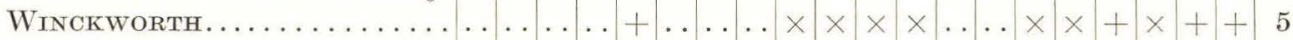

6. Leda (Jupiteria) pygmaea v. MüNst. $+++++\ldots \times \ldots \ldots \ldots+\ldots+\ldots++\ldots+\ldots$

7. Yoldia glaberrima v. Münst. .... . $++++\ldots \ldots \ldots \ldots \ldots \ldots \ldots+\ldots \ldots+\ldots$

8. Arca sp. cfr. decussata Nyst et

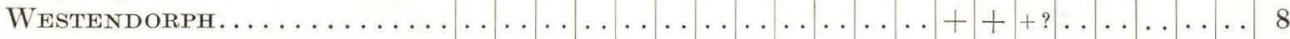

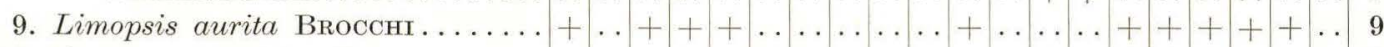

10. Astarte concentrica Goldfuss....... . $+++\ldots \ldots \ldots \ldots \ldots \ldots+\ldots \ldots \ldots$

11.

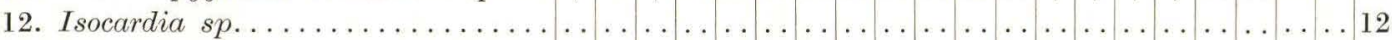

13. Cardium (Laevicardium) subturgi-

dum D'Orbigny ......... $\ldots+\ldots+\times \times \ldots \ldots \ldots \ldots+\ldots+\ldots 13$

14. Cardium (Laevicardium) cingula-

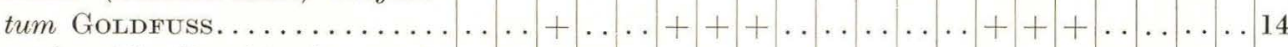

15. Meretrix (Cordiopsis) incrassata

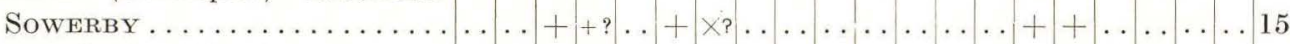

var. flexicostulata KaUtsky . . . . . . . . . . . . . . . . . . . . . . . . .

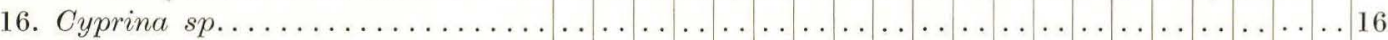

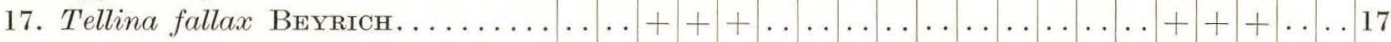

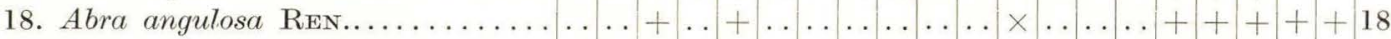

19. Panopaea Ménardi Deshayes........ . . $\ldots+\ldots++++\times \ldots+\ldots++\ldots+\ldots 19$

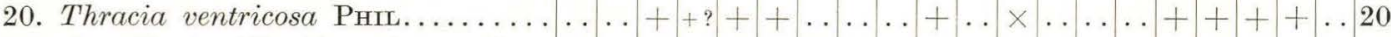

21. Cuspidaria (Cardiomya) costellata

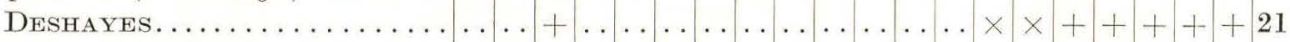

22. Dentalium (Antale) vitreum Sснвӧт. . . . + + $+\ldots \ldots \ldots+\ldots+\ldots \ldots+\ldots+\ldots+\ldots 22$

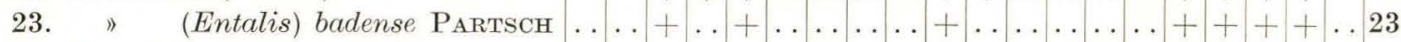

24. Xenophora Deshayesii Мгсн. ......... . . + $+\ldots \ldots+++\ldots \ldots+\ldots+++\ldots+\ldots 24$

25. Solarium Dumontii Nyst.......... . . . . . . . . . . . + + + . . . . . 25

26. Natica (Lunatica) helicina BrocchI $\times \ldots++\times+\ldots \ldots+\ldots+\ldots \ldots+\ldots+++\ldots+26$

27. 》 (Polinices) submammillaris

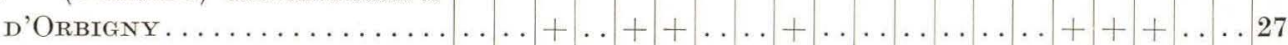

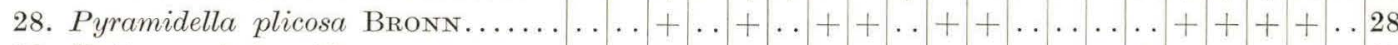

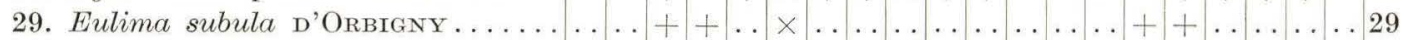

30. Turritella Geinitzi Speyer ........++ $\ldots+\ldots+\ldots \ldots \ldots \ldots \ldots \ldots+\ldots \ldots$

31. Bittium convexorude SAcCO......... ..+ $\ldots+\ldots \ldots \times \times \ldots \ldots \ldots+\ldots+\ldots 31$

32. Newtoniella (Seila) cyrtogyra Coss-

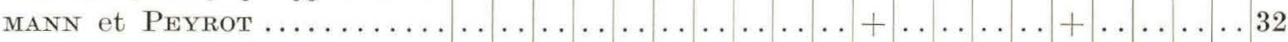

33. Chenopus speciosus Sснцотн. ... . . . . . $\ldots+\ldots \ldots \ldots \ldots \ldots+\ldots+\ldots+\ldots \ldots 33$ var. Margerini de Koninck. . + . +++ ? . . . . . . . . . . . . + + + + $\ldots \ldots \ldots$

1) + betyder at selve Formen, $\times$ at en nærstaaende Form optræder. 
Liste $\left.^{1}\right)$.

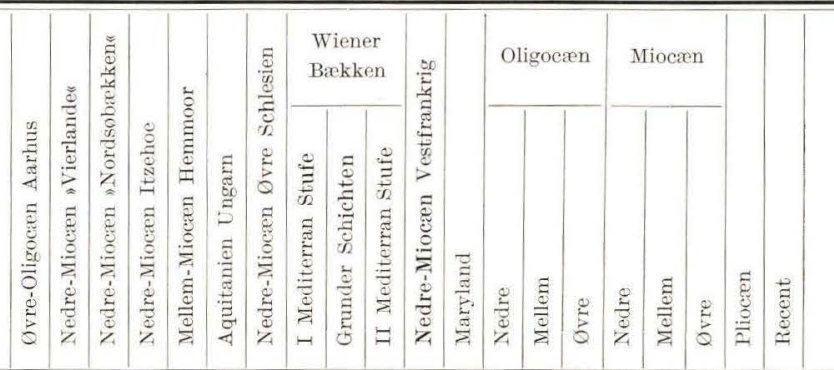

34. Cypraea (Zonaria) amygdatum

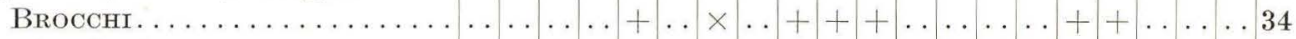

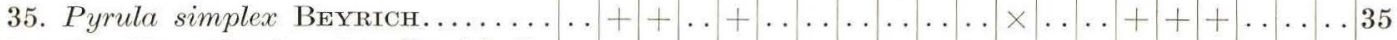

36. Cassidea (Semicassis) Rondeletii

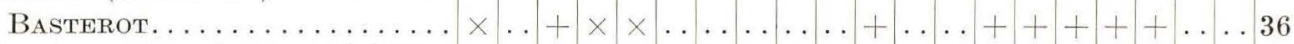

37. Tritonium (Simpulum) enode BEY-

RICH. . . . . . . . . . . . . . . . . . . . . . . 37

38. Murex (Haustellum) paucispinatus

Roth v. Telegd ............. . . . . . . . . . . . . . + . . . . 38

39. Murex (Muricantha) Deshayesii

Nyst..................... . . . . . . . . . $39++++\ldots$

40. Tiphys horridus Brocchi........... . . + . . . . + $+\ldots \ldots \times+\ldots+\ldots+\ldots 40$

41. Atilia (Macrurella)subulata Brocchi . . . . . . . . . . + + . . . . . . . + + $+\ldots 41$

42. Nassa (Telasco) Schlotheimi BEY-

$\operatorname{RICH} \ldots \ldots \ldots \ldots \ldots \ldots \ldots \ldots++++x+\ldots \ldots \ldots \ldots+\ldots \ldots \ldots \ldots$

43. Dolicholathyrus (Pseudolathyrus)

Rothi Beтrich .............. . . . . . . . . . . . . + + + . . +43

44. Streptochetus sexcostatus BEYRICH ... . . $\ldots+\ldots \ldots \ldots \ldots \ldots \ldots \ldots \ldots \ldots+\ldots \ldots 44$

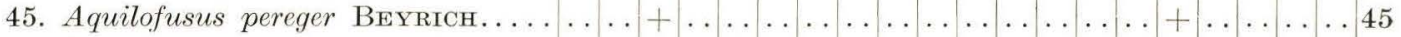

46. Sveltia varicosa Ввосснг........... . . $\ldots+\ldots \ldots \ldots+\times \ldots \ldots \ldots+\ldots+\ldots+\ldots 46$

47. Conus (Leptoconus) Allionii Miche-

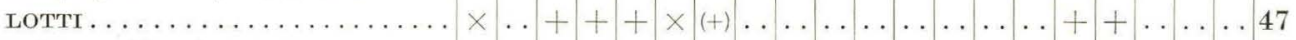

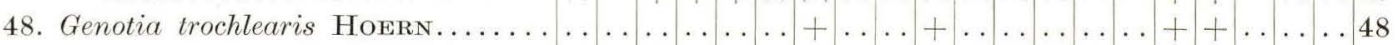

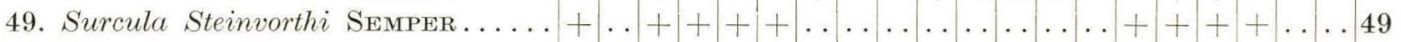

50. Pleurotoma rotata Brocchi........ . + . $\ldots++\ldots \ldots++\ldots \ldots \ldots+\ldots+\ldots+\ldots 50$

51. " trifasciata HoEnnEs . $\quad \ldots+\ldots+\ldots++\ldots+\ldots \ldots \ldots+\ldots+\ldots+\ldots 1$

52. " (Hemipleurotoma) Du-

chastelii $\mathrm{N}$ чsт. ........... $++++++\ldots \ldots \ldots \ldots+\ldots \ldots+\ldots \ldots$

53. Bathytoma cataphracta BrocchI .. $+\ldots+++++++++\ldots+\ldots++++++\ldots 3$

54. Drillia (Cymatosyrinx) Selenkae

v. Koenen................. . . . . ..... . . . . . $\ldots+\ldots+\ldots 54$

55. Daphnella (Raphitoma) Roemeri

PнiL. $s p . \ldots \ldots \ldots \ldots \ldots \ldots \ldots \ldots++++\ldots \ldots \ldots \ldots \ldots \ldots \ldots+\ldots \ldots \ldots$

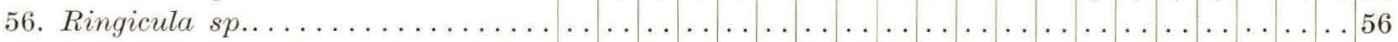

57. Scapander lignarius L.

var. Grateloupi Мгсн. ...........+ $\ldots+\ldots \ldots+\ldots+\ldots+\ldots+\ldots+\ldots 57$

58. Bullinella cylindracea Penn..........+ $++\ldots \ldots \ldots+\ldots+\ldots+++++++++58$

59. , Seebachii v. Koenen... . . . . . . . . . . . . . . . . . . . . . . . 59

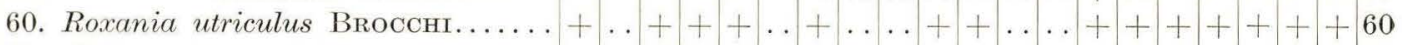

61. Actaeon Phitippi Косн sp.......... $\ldots \ldots \ldots \ldots \ldots \ldots \ldots \ldots+\ldots \times \ldots \ldots \ldots$

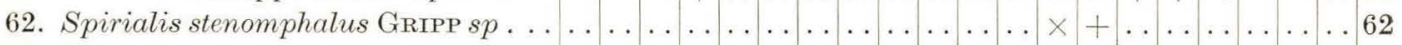

63. Vaginella depressa Daudin...... $\ldots+\ldots+\ldots+\ldots+\ldots++\ldots \ldots+\ldots+\ldots+\ldots+\ldots$

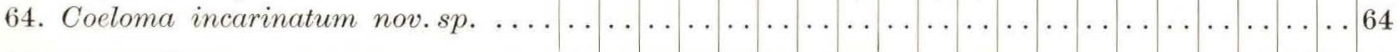




\section{Stratigrafisk Del.}

\section{Klintinghoved-Glimmerlerets Alder.}

Ved Overvejelserne over Glimmerlerets Alder er vi udelukkende henvist til at foretage en Aldersbestemmelse ved Hjælp af Faunaen, idet vi som Følge af, at der er Tale om en Forekomst paa sekundært Leje i glaciale Aflejringer, savner enhver Mulighed for direkte at kunne benytte Lagfølgen som Hjælp ved Løsningen.

I sit grundlæggende Arbejde om Nordsøbækkenets Nedremiocæn kommer GRIPP (37 1915), som nævnt, ogsaa ind paa Glimmerlerforekomsten ved Klintinghoved og dens Fauna og henregner Faunaen til det af ham selv opstillede "Altmiocän«, som i et senere Arbejde fra samme Forfatters Haand benævnes »Vierländer Stufe« (38 1920), et Navn, som siden er accepteret i den geologiske Litteratur.

Den af GRIPP foretagne Aldersbestemmelse maa ogsaa efter de nye Indsamlinger, hvorved Kendskabet til Glimmerlerets Fauna er blevet forøget i væsentlig Grad, anses for at være den rigtige. I det følgende skal vi nu gennemgaa Faunaen og fremdrage dens karakteristiske Træk.

Først de enkelte Formers tidsmæssige Fordeling. Af Tabellen Side 66-67 fremgaar med stor Tydelighed, at et altovervejende Antal af dem er kendt fra nedremiocæne Aflejringer, idet 54 af 64 Arter, altsaa $84 \%$ af det samlede Antal hidtil fremdragne Former, kendes fra saadanne Aflejringer. Af de resterende 10 har Nucula hanseata KAUTSKY en nærstaaende Form i Nedremiocænet i Nucula laevigata Sow. Desuden er det højst sandsynligt, at der blandt de Former i Nedremiocænet, som er henført til Nucula laevigata, ogsaa findes saadanne, som maa henregnes til $N$. hanseata ${ }^{1}$ ). Af de 9 Former, der bliver til Rest, er kun Genusnavn bestemt for de 4, og een Form, en Crustacé, er ny.

1) I denne Sammenhæng skal nævnes, at Gripp fra Sonderborg (= Klintinghoved) anforer N. laevigata; i det Materiale, som ligger til Grund for dette Arbejde, forekommer imidlertid udelukkende $N$. hanseata, som iovrigt opstilledes, efter at Gripp foretog sin Bestemmelse. Den fremsatte Formodnings Sandsynlighed fremgaar derfor af dette Exempel. 
Det store Procenttal maa dog ikke dupere for meget. Et Blik paa Fossillisten viser, at en overordentlig stor Del af Arterne har stor vertikal Udbredelse. M. H. t. den vertikale Udbredelse er der dog en Del Former, der skiller sig ud fra de øvrige; i ganske særlig Grad gælder dette Aquilofusus pereger BEYR., der af GRIPP anføres som Ledefossil for Vierländer Etagen. Den af Cossmann og Peyrot opstillede Form Newtoniella cyrtogyra kendes ogsaa foreløbig kun fra Nedremiocænet. Tritonium enode Beyr. og Turritella Geinitzi SPEyer er vigtige, paa Grund af at de kun optræder i Øvreoligocæn-Nedremiocæn, ikke i Aflejringer af anden Alder.

Ogsaa Murex (Haustellum) paucispinatus Roth v. Telegd, Conus (Leptoconus) Allionii Мгсн. og Genotia trochlearis Hoennes er interessante Former; de er hidtil kun fundet i nedremiocæne og mellemmiocæne Aflejringer.

Ved Hjælp af de her omtalte Arter kan vi naa til en relativ nøjagtig Tidsbestemmelse, idet vi er saa heldige at kunne indkredse Aldersproblemet paa to Maader, baade den direkte ved Hjælp af Ledefossilet $\mathrm{og}$ den indirekte ved Hjælp af flere Former, der udelukker andre Muligheder end den, at Faunaen er nedremiocæn og maa henregnes til Vierländer Etagen.

Det klassiske Sted for Vierländer Etagen er »die Vierlande« S. f. Hamburg, hvor det lykkedes GRIPP (35) i et Antal Boringer at paavise fossilførende marint Nedremiocæn direkte over Øvreoligocæn, saavidt man kan dømme med jævn Overgang. Fra disse miocæne Lag offentliggjorde GRIPP en Fauna paa 22 Arter, hvoraf 8 er fælles med Klintinghoved.

Ser vi paa den af GRIPP givne Faunaliste i Arbejdet »Das Altmiocän des Nordseebeckens«, viser det sig, at 48 af de 64 Arter fra Klintinghoved ogsaa findes anført her, som vist i tredie Søjle i Fossillisten pag. 66-67. Holder man sig til Forekomsterne paa primært Leje omtalt i det citerede Arbejde af GRIPP, Boringerne med fossilførende nedre Miocæn fra Lübeck, Wismar, Blekede og det ovenfor omtalte Hamburg-Vierlande, bliver Resultatet, at Klintinghoved Faunaen har 28 Arter (heraf 3 usikre) fælles med disse Faunaer, d. v. s. mellem $39 \%$ og $43 \%$.

At man ved Aldersbestemmelsen imidlertid ikke udelukkende maa tage Hensyn til den procentiske Sammensætning m. H.t. Fællesformer, viser en Sammenligning med den yngre mellemmiocæne Hem moorer Fauna, der er beskrevet af Kautsky (49). Med denne Fauna har Klintinghoved 38 Former fælles, altsaa $59 \%$ af den samlede Klintinghoved Fauna; endvidere findes mellem Fællesformerne de to Arter Cypraea (Zonaria) amygdalum Brocchi og Murex paucispinatus Roth v. Telegd som KaUtsky sammen med andre Former anser for at være karakteristiske for de mellemmiocæne Hemmoor- og Dingden-Reinbek-Etager indenfor Nordsøbækkenet. I denne Forbindelse skal der gøres opmærksom 
paa, at disse to Former er fundet i nedremiocæne Aflejringer i henholdsvis Vestfrankrig og Ungarn. At der findes saa mange flere Fællesformer mellem Klintinghoved og Hemmoor end mellem Klintinghoved og de jævnaldrende Forekomster i de ovenfor anførte nordtyske Boringer ligger bl. a. deri, at der er kendt langt færre Former fra Boringerne end fra det velundersøgte Hemmoor Miocæn.

Den Kendsgerning at to Faunaer saaledes i høj Grad kan minde om hinanden uden dog at være af samme Alder, samtidig med at den ene kan have færre Former at opvise, som er fælles med en anden synkron Fauna, er noget, man ofte kan møde, især ved hinanden i Tid nærliggende Faunaer indenfor samme Aflejringsomraade. De isopiske Facies har i saa Tilfælde større Indflydelse end Tidsfaktoren, og det afgørende ved Aldersbestemmelsen vil være Ledefossilerne.

En meget vigtig Ting er ogsaa, som antydet ovenfor, Faunaernes indbyrdes absolute Størrelse. Som Exempel skal her efter Bucquor (12 II p. 755) anføres, at den nulevende marine Fauna ved Norges Kyst har $52 \%$ af sine Arter fælles med Middelhavet, hvorimod den af BucQuoY undersøgte meget større Middelhavsfauna har 25\% af sine Arter fælles med den norske Fauna; den fattigere Faunas Arter drukner paa en vis Maade $\mathrm{i}$ den rige Faunas.

Efter denne Udredning maa man komme til det Resultat, at Klintinghoved Faunaen maa være jævnaldrende med Vierländer Etagen, som af GRIPP antages for at være synkron med Aquitanien'et som Følge af det store Indhold af oligocæne Arter. Den aquitaniske Alder bestrides dog af KAUTSKY (49 p. 207), som tværtimod anser GRIPP's »Altmiocän« for at høre hjemme i Burdigalien, fordi den imellem det marine Nedremiocæn og den marine Hemmoor Etage liggende Serie af limnisk-æstuarine Lag, bestaaende af Brunkulssandaflejringer, efter KaUtsky's Mening ikke kan ekvivalere med det imellem Hemmoor Etagen (der af Kautsky henføres til Helvétien) og Aquitanien Etagen beliggende Burdigalien. Dette begrunder Kautsky med, at Faunadifferencerne mellem Vierländer og Hemmoor Etagerne er for smaa, til at de kan skilles af en hel Etage.

Vi skal senere komme tilbage til denne Divergens i de to Forfatteres Aldersopfattelse. 


\section{Klintinghoved-Faunaens Relationer til andre europæiske Miocæn-Faunaer.}

\section{A. Nordsøbækkenet.}

GRIPP (3\%) har givet en god, sammenfattende Oversigt over Nordsøbækkenets Nedremiocæn og dets Fauna. Denne Forfatter kommer til det Resultat, at der i Holland-Belgien ikke forekommer nedremiocæne Lag, men mener derimod at kunne henføre de af RAvN (95) fra Skyum, Skive, Viborg og Varde publicerede Faunaer til Nedremiocænet, idet bl. a. Aquilofusus pereger BEYR. er fundet paa disse Lokaliteter med Undtagelse af Skive, hvorfra den ikke kendes.

Skyum Faunaen minder meget om Klintinghoved Faunaen, den har samme Præg; gamle oligocæne Former og nyere miocæne findes sammen. Følgende Arter er fælles for de to Findesteder:

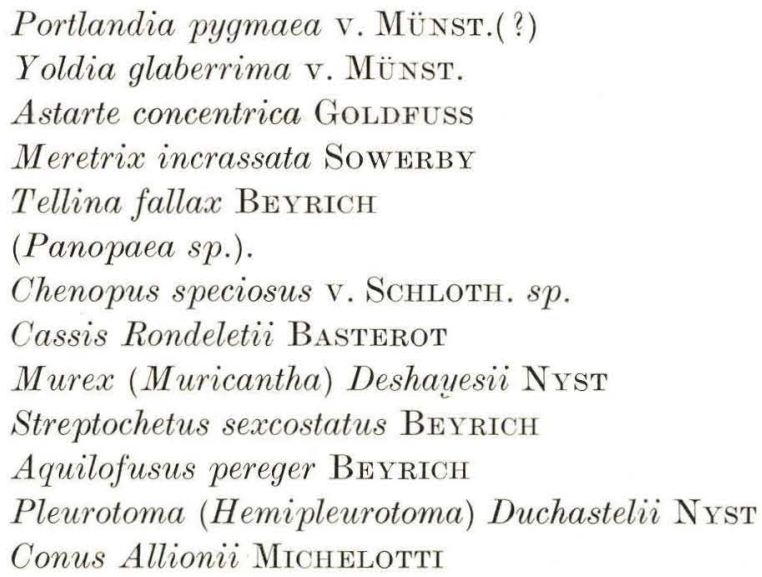

Iøvrigt skal efter RAvN anføres, at man fra Skyum kender ialt 24 Arter, hvoraf 3 er usikre.

De anførte Former viser med al Tydelighed, at vi har at gøre med en Fauna af samme Alder og lignende Sammensætning som Klintinghoved Faunaen.

Nedremiocænet i Itzehoe, der er beskrevet af GRIPP (36), har omtrent de samme Former fælles med Klintinghoved; der er Tale om følgende, der findes opført i Fossillisten pag. 66-67:

Leda (Jupiteria) pygmaea v. Münst.

Yoldia glaberrima v. Münst.

Limopsis aurita BRocchI

Astarte concentrica GOLDF. 
Cardium (Laevicardium) subturgidum D'ORB.

Tellina fallax BEYR.

Dentalium (Antale) vitreum Sснвöт.

Natica (Lunatia) helicina BRoccHI

Eulima subula D'ORB.

Turritella Geinitzi SPEYER

Chenopus speciosus var. Margerini DE KoN.

Tritonium (Simpulum) enode BEYR.

Murex (Muricantha) Deshayesii Nyst

Nassa (Telasco) Schlotheimi Beyr.

Conus (Leptoconus) Allionii МroH.

Surcula Steinvorthi SEMPER

Pleurotoma (Hemipleurotoma) Duchastelii Nyst

Bathytoma cataphracta BRocchI

Daphnella (Raphitoma) Roemeri PнIL.

Scaphander lignarius L. var. Grateloupi МıсH.

Bullinella cylindracea Penn.

Roxania utriculus BRocCHI

Actaeon Philippi KocH sp.

Disse to Faunaer turde staa Klintinghovedfaunaen meget nær.

En anden Fauna, som ligeledes maa antages at være jævnaldrende med Klintinghoved Miocænet, er den Fauna, der findes i løse Blokke omkring Flensborg Fjord (GRIPP 3\%, Sorgenfrei 109). Jeg haaber ved en anden Lejlighed at kunne give en nøjere Skildring af denne Fauna, der findes baade i Sandstensfacies og Lerfacies (SorgEnfrer 109); den har stor Interesse ved, at den paa mangfoldige Punkter supplerer vort Kendskab til Dyrelivet i den miocæne Nordsø. I Søjlen Nr. 9 i Fossillisten har GRIPP (3\%) 1915 givet en Sammenstilling af de dengang fra Blokkene kendte Arter, hvortil jeg skal henvise. Arternes Antal kan nu forøges i væsentlig Grad.

I Fossillisten Side 66-67 er i tredie Søjle anført de Arter, der er fælles for Klintinghoved og GRIPP's "Altmiocän« (3\%). Ved Betragtningen af Listen viser det sig bl. a., som allerede nævnt, at man nu maa regne med, at Cypraea amygdalum og Murex paucispinatus gaar ned i Nedremiocænet, og de kan ikke, som fremsat af KAUTsky, anses for Karakterformer for Hemmoor Etagen og Mellemmiocæenet i det hele taget. Disse to Former er interessante ved, at man maa anse dem for Repræsentanter for en sydligere, varmere Fauna, der i hine Tider havde sin Hovedudbredelse i Middelhavsomraadet og sandsynligvis ogsaa ved de sydeuropæiske Atlanterhavskyster.

Forholdet mellem Klintinghoved og de sikkert primære Forekomster i de nordtyske Boringer er ovenfor ridset op under Omtalen af Alderen. 


\section{B. Øvre Schlesien, Wienerbækkenet og det ungarske Bækken.}

\section{1. Øvre Schlesien.}

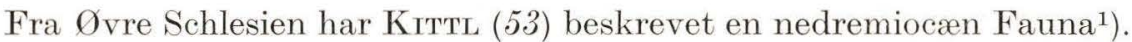
KiтtL kommer til det Resultat, at Øvre Schlesiens ældste miocæne Aflejringer som Følge af Faunaens blandede Præg (der findes baade oligocæne og miocæne Arter) maa henlægges til den allerældste Del af I Mediterranstufe d. v. s. af Nedremiocænet. Der er efter KiтTL Tale om en ægte Dybhavsfauna med en Aflejringsdybde mellem 100 og $500 \mathrm{~m}$, hvorfor der ikke findes saa mange Arter fælles med første Mediterran Etagen i Horner Bækkenet — den extraalpine Del af Wienerbækkenet hvor der er Tale om Lavvandsaflejringer med et helt andet Præg (SCHAFFER, 100, 101) med talrige Lamellibranchiater; Gasteropoderne derimod forekommer i mindre Artsantal.

Med Øvre Schlesiens Nedremiocæn har Klintinghoved følgende Arter fælles:

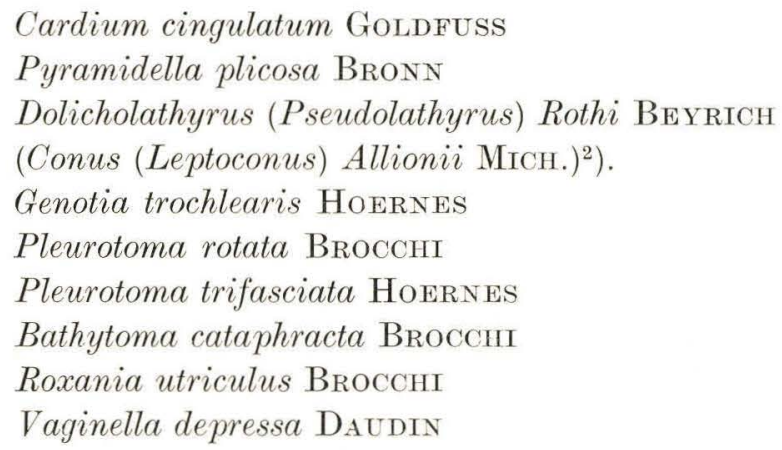

Desuden er fundet følgende Former, der har Interesse ved, at de har nærstaaende Former i Klintinghovedfaunaen:

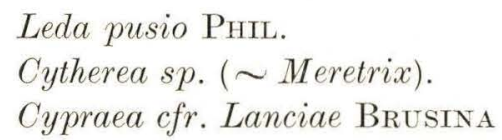

1) Kautsky (50 pag. 51) fremsætter den Mening, at Faunaen er mellemmiocæn, uden at anfore nogen reel Grund udover at henvise til, at der er Tale om en ejendommelig Blandingsfauna, hvilket iovrigt allerede er paapeget af KrTt.. Da det forekommer mig, at KiтtL's Tolkning er mere naturlig, henholder jeg mig til denne.

$\left.{ }^{2}\right)$ Denne Art anfores i Parentes, fordi dette ogsaa er Tilfældet i det citerede Arbejde af Kiтtu og skyldes, at Kiтtu ikke har været i Stand til at kontrollere Bestemmelsen (foretaget af Custos Th. Fuchs). 
Mellem de citerede Arter maa man især hæfte sig ved Genotia trochlearis, denne ret sjældne Form, der ellers kun kendes fra Wienerbækkenet (II Mediterran Etage), Siebenbürgen, Helvétien i Norditaliens Colli torinesi og Klintinghoved. Vigtige Former er ogsaa Cardium cingulatum og Conus Allionii, der tidsfæster Faunaen til Nedremiocæn idet Cardium cingulatum kendes fra Mellemoligocæn til Nedremiocæn, Conus Allionii fra Nedremiocæn til Mellemmiocæn.

Foruden dette er det af Vigtighed at fastholde KiTTL's Understregning af den Tilknytning, der findes til Nordtysklands oligocæne Fauna.

\section{Wienerbækkenet.}

I Wienerbækkenet kendes tre Underafdelinger af Miocænet i Aldersfølgen: I Mediterranstufe, Grunder Schichten og II Mediterranstufe, der efter ScHaffer (102) bør henføres til henholdsvis: Burdigalien, Helvétien og Tortonien.

I Mediterran Etage er især kendt i Lavvandsfacies, Grunder Etagen findes udformet som fossilførende Mergel, II Mediterran Etage som Kalk- og Leraflejringer.

Selv om den første Mediterran Etage i Alder staar Klintinghovedfaunaen nærmest, findes her kun faa Arter fælles med Klintinghoved. Fællesformernes Antal bliver tværtimod størst, efterhaanden som man naar op til Grunder- og anden Mediterran Etage. I denne sidste findes 22 Arter, der er fælles med Klintinghoved; de har alle stor vertikal Udbredelse. Atter her har vi et Exempel paa Faciesforholdenes relativt større Indvirkning paa Faunaerne end Alderen.

Følgende Former har Klintinghoved fælles med den første Mediterran Etage:

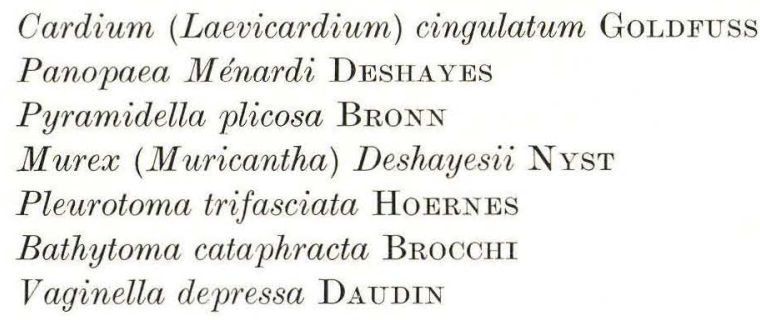

Faunaforskellene mellem I Mediterran Etage og Klintinghovedfaunaen maa ikke alene tilskrives Faciesforskellene, som er omtalt foroven, man maa ogsaa antage, at andre fysiske Forhold, først og fremmest klimatiske og geografiske, og endvidere en Aldersforskel gør sig gældende. Aldersforskellen skal vi komme tilbage til senere. 


\section{Det ungarske Bækken.}

Konnekteringen med de ældste miocæne Faunaer i Ungarn spiller en særlig vigtig Rolle, fordi vi derved faar indpasset Vierländer Etagen i det almindelige europæiske Etagesystem indenfor Miocænet.

Af de ungarske Faunaer, der skal omtales her, er den første beskrevet i Litteraturen af Roth v. Telegd 1914 (119). Faunaen er fundet i Nærheden af den ungarske By Eger i en Teglværksgrav; den danner Overgang mellem Oligocænet og Miocænet, og Roth v. Telegd henførte da, med særlig Henblik paa det oligocæne Moment, Faunaen til Øvreoligocæn, Cattien'et.

Ved en Betragtning af Faunaen viser det sig imidlertid, at det oligocæne Kontingent udgøres af Former, der for en stor Del findes i det nordtyske Oligocæn; de øvrige Faunaelementer maa derimod siges at bære Præg af at tilhøre de miocæne mediterrane Faunaer. I sine Konklusioner siger Roth v. Telegd p. 72 bl. a.: "Es lässt sich in der Tat schwer eine Fauna vorstellen, die den Übergang aus dem Oligozän in das Miozän besser demonstrieren würde, wie die Fauna von Eger - Am meisten noch stimmt sie mit der Fauna unseres Mediterrans überein, von den älteren aber mit der aquitanischen Fauna der Bucht von Bordeaux und der oberoligozänen Fauna der bairischen unteren Molasse, also eben mit jenen, in denen den miozänen Elementen ein grösserer Anteil zukomnt, wie in den norddeutschen Faunen, die als Typus der oberoligozänen Faunen figurieren.«

Alligevel henfører Roth v. Telegd den af 75 Arter bestaaende Fauna til Øvreoligocæn.

Underkaster man nu de omtalte nordlige oligocæne Elementer en nøjere Undersøgelse, viser det sig, at et stort Antal af dem ogsaa gaar op i Nordsøbækkenets Nedremiocæn, saaledes at Forudsætningerne for en Henlæggelse af Faunaen til Øvreoligocæn forringes væsentligt.

I 1936 fremkom J. Noszky (81) med et Arbejde - „Die Molluskenfauna des oberen Cattiens von Eger« —, i hvilket behandles et rigt Materiale, indsamlet i Aarene efter 1914 i samme Teglværksgrav, hvorfra Roth v. Telegd beskrev sin Fauna. Noszky beskriver nu ialt 324 Former. Faunaens Alder anses stadig for at være øvreoligocæn, selvom det miocæne Præg ikke formindskes ved de ny tilkommende Arter.

Det ligger ikke indenfor dette Arbejdes Rammer at komme ind paa en Diskussion af denne Fauna, saa meget mere som den indgaaende er diskuteret af ST. V. GAÁL i 1938 i Afhandlingen: „Über die mit der Egerer gleichalterige tertiäre Molluskenfauna von Balassa-Gyarmat und das Oligozän-Problem« (26).

Ved Behandlingen af Faunaen fra Balassa-Gyarmat trænger Spørgsmaalet om Egerfaunaens oligocæne eller miocæne Alder sig paany frem. 
Ledet af stratigrafiske Overvejelser og Betragtninger over, hvor stor en Del af Faunaen de »oligocæne« Elementer indtager m. H. t. den procentiske Andel baade i Artsantallet og Individantallet, kommer GAÁL til det Resultat, at man maa henregne Eger- og Balassa-Gyarmat-Faunaerne til den allernederste Del af Miocænet, nemlig Aquitanien, idet han ogsaa gør gældende, at man i Faunabilledet bør tillægge de yngre Elementer større Betydning end de fra en ældre Tidsperiode persisterende Former.

Sammenholder vi dette med, hvad der ovenfor er sagt om de oligocæne Formers Tilstedeværelse indenfor Nordsøbækkenets Nedremiocæn, kan vi ikke komme til andet Resultat, end at GAáL's Slutninger maa komme Virkeligheden nærmest.

I Fossillisten Side 66-67 er i Søjle 6 anført de Arter, som Klintinghoved har fælles med de aquitaniske Faunaer i Ungarn, Eger og Balassa-Gyarmat, som her er slaaet sammen. Følgende Former forekommer baade i Klintinghoved og Ungarn:

Cardium (Laevicardium) cingulatum GoLdF.

Meretrix (Cordiopsis) incrassata Sow.

Thracia ventricosa PHIL.

Xenophora Deshayesii Мгсн.

Natica (Lunatia) helicina BRocchI

Natica (Polinices) submammillaris D'ORB.

Turritella Geinitzi SPEYER

Bittium convexorude SACCo

Chenopus speciosus v. ScHLотн. $s p$.

Murex (Haustellum) paucispinatus Roth v. Telegd

Murex (Muricantha) Deshayesii NysT

Tiphys horridus BRoccHI

Nassa (Telasco) Schlotheimi BeyrICH

Surcula Steinvorthi SEMPER

Pleurotoma rotata BROCCHI

Pleurotoma (Hemipleurotoma) Duchastelii Nyst

Bathytoma cataphracta BRoccHI

Endvidere findes nærstaaende Former til:

Klintinghoved :

Ungarn:

Cardium subturgidum D'ORBIGNY

(Cardium comatulum BRonN)

Eulima subula D'ORB.

Tritonium enode BEYR.

(Eulima cfr. subulata DoN.)

Sveltia varicosa BRocchI

(Tritonium tarbellianum GRAT. var.)

Conus Allionii Мrch.

(S. varicosa BR. var. miocenica DöD.)

(C. Dujardini Desh.var. brevispiratus

Noszky). 
En Fauna med denne Sammensætning vilde i Nordsøbækkenet blive regnet til Nedremiocænet.

Sammenligner vi iøvrigt den af Noszky, GaÁl og Roth v. Telegd beskrevne Fauna med Faunaen i GrIPP's »Altmiocän« (3\%), kommer vi endvidere til det Resultat, at den ungarske Fauna er den Fauna udenfor Nordsøbækkenet, der minder mest om Vierländer Etagens Fauna. Disse Kendsgerninger harmonerer derfor ogsaa paa skønneste Maade med GrIPP's og GaÁL's Antagelse af, at de respektive Faunaer hører hjemme i Aquitanien.

Naar Kautsk y bestrider »Altmiocän'ets« aquitaniske Alder sker dette øjensynlig under Indvirkning af OpPenHeIms Kritik af GrIPP's Arbejde (89). De Indvendinger, Kautsky (49) rejser mod GrIPP's Aldersbestemmelse, er imidlertid ret svage, bl. a. paapeger Kautsky den ringe Overensstemmelse mellem l'Aquitanien i Bordeaux Bækkenet og "Altmiocän'et«. Herpaa giver GRIPP dog selv en Forklaring i sit Arbejde, derigennem at han omtaler, at Strædet ved Calais, saa vidt man kan skønne, ikke eksisterede i Nedremiocænet, en Antagelse, som KaUtsky selv tiltræder senere ved sin Omtale af Udbredelsesforholdene for de forskellige miocæne Faunaer indenfor de europæiske Havomraader.

I Landbarrièren, der i Nedremiocænet skilte de sydvestevropæiske Have fra Nordsøen, laa en i Ordets egentlige Forstand uoverstigelig Hindring for Faunaens Fremtrængen fra Sydvest over Kanalens nuværende Omraade. Kun de mere nordlige Arter, der taalte en lavere Temperatur saa langt nordpaa som i Havet mellem England og Skandinavien, kunde immigrere i Nordsøen.

KAUTSKY anfører endvidere, at en Del af Altmiocänets Former i Mediterranomraaderne først optræder i Helvétien og Tortonien. Disse Formers Tal er dog efter Fremkomsten af de nye ungarske Faunaer formindsket betydeligt; endvidere er den Mulighed efter min Mening heller ikke udelukket, at saadanne Formers Optræden eller ikke Optræden ogsaa maa skyldes klimatisk betingede Faktorer. Ved Hjælp af disse Formers Optræden mener KAUTSKY nu at kunne rykke Vierländer Etagen højere op i Tidsskemaet, idet han til Slut anfører det indirekte Bevis herfor, at Faunadifferencerne mellem Nedremiocænet og Hemmoor Etagen (som af KAUTSKY anses for at være af helvetisk Alder) er for smaa til, at de imellem Vierländer og Hemmoor Etagerne liggende Lag af limnisk-fluviatilt Brunkulssand skulde kunne udgøre den imellem Aquitanien og Helvétien beliggende Burdigalien Etage.

Til Kautsky's Anskuelser er der nu det at sige, at en meget vigtig Kendsgerning ikke indgaar som et Led i hans Betragtninger over Altmiocänets Alder, nemlig den, at det marine Øvreoligocæn udmærker sig ved at gaa jævnt over i marint Nedremiocæn, naar dette findes paa primært Leje. Saa vidt man kan se findes intet, der kunde tydes som en Af- 
brydelse i Sedimentationen i Tidsrummet Øvreoligocæn-Nedremiocæn (GRIPP 35. 3\%.); med andre Ord, vi har en kontinuerlig Sedimentation i dette Tidsrum. Den logiske Følge er derfor, at GRIPP's Altmiocän maa være det ældste foreliggende Miocæn, altsaa Aquitanien, idet vi følger Dollfus og Cossmann ved at anbringe Aquitanien som nederste Etage i Miocænet.

Til KaUtsky's saakaldte indirekte Bevis mod Vierländer Etagens aquitaniske Alder skal blot anføres, at et Sediments Tykkelse, i dette Tilfælde Brunkulssandets, altid vil være meget vanskelig at bruge i Forbindelse med Tidslængde, da man ikke har noget sikkert Maal for, hvor meget der aflejres i en given Tid paa et givet Sted.

M. H. t. de store Lighedstræk, der findes mellem Vierländer og Hemmoor Etagernes Fauna skal jeg henvise til, at man i de danske Boringer (vi behøver blot at nævne de af RAvn (95) meddelte Boreprofiler fra Viborg og Varde) ikke har truffet paa Brunkulssandet over Nedremiocænet, som det kendes fra de nordtyske Lokaliteter, omtalte af GRIPP o. a. Der synes tværtimod i Danmark at foreligge typisk marine Lag i største Delen af Miocænet, uden intermediære Lag af Brunkulssand ${ }^{1}$ ). Som Følge heraf har man god Grund til at antage, at Brunkulssandet i Nordtyskland er et mere eller mindre lokalt Fænomen. Det kan med andre Ord forklares ved en Regression i det nordtyske Omraade, som dog ikke har omfattet hele den miocæne Nordsø, der har fortsat sin Existens i de nordlige Dele af Nordsøbækkenet. Overensstemmelserne i Vierländer og Hemmoor Etagernes Fauna forklares derfor bedst ved, at Vierländer Faunaen sammen med Havet trak sig tilbage fra det nordtyske Omraade under Brunkulssandets Dannelse, men levede videre længere ude i Nordsøen. Herfra vandrede Faunaen igen mod Syd under Hemmoor Etagens Aflejring, da Havet atter transgredierede over Nordtyskland; saaledes kunde mange af de fra Vierländer Etagen kendte Former atter optræde.

Inden vi forlader Hemmoor Etagen er der Grund til at paapege en Uoverensstemmelse mellem Kautsky's Henlæggelse af Hemmoor Faunaen til Helvétien og hans samtidige Parallelisering af Hemmoor med Wiener Bækkenets anden Mediterran Etage. Som meddelt Side 74 anses denne Etage for at høre hjemme i Tortonien, hvorfor de to Ting udelukker hinanden. Bibeholdes Hemmoor Etagens helvetiske Alder maa dens. Fauna derfor være jævnaldrende med Grund Etagen i Wiener Bækkenet.

1) De af RAvN omtalte og af Gripp (37) ved Behandlingen af Nedremiocæenet fremdragne tertiære Sandaflejringer med Brunkul, bl. a. ved Viborg, ligger højere oppe i Lagserien og er muligvis meget yngre. Da det er mig bekendt, at Herr stud. mag. K. Dreyer JøRGENSEN for Tiden studerer disse Aflejringer, skal jeg forelobig afholde mig fra videre Diskussion og kun understrege, at der ikke synes at være Tale om limniske Lag, indskudt i det marine Miocæn. 
Ved Afslutningen af denne Behandling af Lighedspunkterne mellem Nordsøbækkenet og det ungarske Bækken er det værd at understrege, at vi begge Steder finder Faunaer, der forbinder Oligocænet med Miocænet; gamle Former fortsætter deres Existens, nye afvigende Former holder deres Indtog. Paa denne Maade faar vi to meget værdifulde Paralleler til Belysning af Overgangsperioden mellem de to Tidsafsnit samt et vigtigt Hjælpemiddel ved Synkroniseringen af det nord- og sydeuropæiske Neogen ${ }^{1}$ ).

I det følgende Skema er til Oversigt foretaget en Sammenstilling af de fra Nord-og Sydeuropa her omtalte mellem-og nedre-miocæne Faunaer.

\begin{tabular}{|c|c|c|c|}
\hline & & $\begin{array}{c}\text { Nordtyskland } \\
\text { efter Gripp }(37,38) \text { KaUtsky } \\
(49) \text { og E. Косн }(57) \text {. }\end{array}$ & $\begin{array}{l}\text { Wiener Bækken, Ungarn } \\
\text { og Øvre Schlesien } \\
\text { efter Schaffer (102), GaÁL (26) } \\
\text { Og Krttu (53). }\end{array}$ \\
\hline $\begin{array}{l}\text { Øvre } \\
\text { Miocæn }\end{array}$ & Pontien & & \\
\hline \multirow{3}{*}{$\begin{array}{l}\text { Mellem } \\
\text { Miocæn }\end{array}$} & Sarmatien & Reinbek Etage & Cerithium Lag \\
\hline & Tortonien & Øvre Brunkulssand & 2den Mediterran Etage \\
\hline & Helvétien & $\begin{array}{l}\text { Hemmoor Etage } \\
\text { Hamburger Ler }\end{array}$ & "Grunder Schichten" \\
\hline \multirow[b]{2}{*}{$\begin{array}{l}\text { Nedre } \\
\text { Miocæn }\end{array}$} & Burdigalien & Nedre Brunkulssand & 1ste Mediterran Etage \\
\hline & Aquitanien & Vierländer Etage & $\begin{array}{c}\text { Marine Lag ved Ostrau } \\
\text { Karwin i Øvre Schlesien } \\
\text { og ved Eger og Balassa- } \\
\text { Gyarmat i det ungarske } \\
\text { Bækken }\end{array}$ \\
\hline $\begin{array}{c}\text { Øvre } \\
\text { Oligocæn }\end{array}$ & Chattien & & \\
\hline
\end{tabular}

1) GAÁL (26) foreslaar en ny Inddeling af Tertiær-Kvartær: Paleocæn og Eocæn kaldes for Palaeogen, Oligocæn og Miocæn for Mesogen, Pliocæn og Kvartær for Neogen. 


\section{Bordeaux-Bækkenet i Vest Frankrig.}

Med de nedremiocæne Faunaer i Bordeaux Bækkenet, Aquitanien og Burdigalien Etagerne, har Klintinghoved følgende Arter fælles:

Limopsis aurita BROCCHI

Panopaea Ménardi Deshayes

Dentalium (Antale) vitreum ScHRöт.

Xenophora Deshayesii MicH.

Pyramidella plicosa BronN

Newtoniella (Seila) cyrtogyra Cossm. et PEYR.

Cypraea (Zonaria) amygdalum BRocCHI

Cassidea (Semicassis) Rondeletii Basterot

Tiphys horridus BroccHI

Pleurotoma rotata BRocchI (?)

Bathytoma cataphracta BRocCHI

Scaphander lignarius L. var. Grateloupi Мıсн.

Bullinella cylindracea PENN.

Roxania utriculus BrocchI

Vaginella depressa DAUDIN

Desuden findes nærstaaende Arter eller Varieteter til:

Nucula nucleus L. var. Hanleyi WInckw. og

Bittium convexorude SACCO

Den Kendsgerning, at der mellem det aquitaniske Bækken og Nordsøbækkenets Nedremiocæn i Almindelighed findes saa faa fælles Arter, forklarer GRIPP (3\%) som nævnt ved, at Pas de Calais ikke eksisterede i Nedremiocænet. Det kan derfor heller ikke forbavse, at de Former, der er fælles, er saadanne med stor vertikal og geografisk Udbredelse. Disse Arter behøver saaledes ikke at være Udtryk for en direkte Udveksling mellem de to Omraader, men maa snarere tolkes enten som endemiske Former, der har holdt sig siden Oligocænet i begge Omraaderne, eller ny indvandrede Former, der har deres Oprindelse et tredie Sted. Som Exempel paa dette sidste skal nævnes Cypraea amygdalum, der maa antages at være kommet til Nordsøbækkenet over de mediterrane Omraader.

Kautsky (49) belyser ved en Sammenligning mellem de forskellige Etagers Fauna SV og NØ for Kanalen, at Landforbindelsen mellem England og Frankrig sandsynligvis ophørte med at eksistere i Hemmoor Etagens Tid, idet Relationerne mellem den sydvestfranske Fauna og Faunaen i Nordsøbækkenet da bliver meget mere udtalt, end i Nedremiocænet. 


\section{Sammenligninger med tertiære Faunaer i Nordamerika og Østgrønland.}

\section{Nordamerika.}

Før vi gaar over til en Sammenligning med amerikanske og grønlandske Faunaer, skal forudskikkes den Bemærkning, at der her ikke kan være Tale om en saa snæver Sammenligning som med de ovenfor omtalte europæiske Faunaer, idet en saadan i høj Grad vanskeliggøres ved, at en Synkronisering paa de to Sider af Atlanterhavet viser sig ikke at kunne foretages med en til dette Formaal tilstrækkelig Nøjagtighed, heller ikke ad faunistisk Vej. Da de amerikanske Faunaer før har været fremme i Forbindelse med de her omtalte Faunaer fra Nordsøbækkenet, skal vi dog komme ind paa Spørgsmaalet.

Imellem de nordamerikanske miocæne Aflejringer er det vigtigt i denne Sammenhæng at beskæftige sig med »The Chesapeake Series« fra Maryland, samt Tampa Formation og Alum Bluff Group i Florida, der har leveret rige marine Faunaer. De er alle studeret af DALL $(18,19)$. Den sidste Gruppes marine Molluskfauna bliver for Tiden gjort til Genstand for en monografisk Behandling af JuLta Gardener (28).

Under deres Forsøg paa at korrelere de amerikanske Tertiæraflejringer med det europæiske Tertiær, er de amerikanske Geologer (121) kommet til det Resultat, at Tampa Formation og Alum Bluff Group sandsynligvis maa anses for at være jævnaldrende med henholdsvis Aquitanien og Burdigalien-Helvétien i Europa; The Chesapeake Series, der bestaar af Calvert-, Choptank- og St. Marys-Formation, henregnes til Tortonien.

Hvorvidt denne Parallelisering er rigtig eller ej skal vi ikke komme ind paa her, hvor vi kun skal opregne de Former i Faunaerne, der udviser Lighedstræk med Formerne fra Klintinghoved og dertil knytte en Del Bemærkninger om eventuelle Vandringer. Ved denne Sammenligning er det nemlig tilstrækkelig nøjagtigt, om man for de amerikanske Aflejringer antager en Alder mellem Øvreoligocæn og Mellemmiocæn inclusive, da de Arter, der fremdrages af Klintinghovedfaunaen, vertikalt har en saadan Udbredelse. Denne sidste Kendsgerning berettiger saaledes Sammenligningen, naar man gaar ud fra, at den amerikanske Synkronisering med Europa i det store og hele er rigtig.

Følgende Former viser Lighedstræk:

Klintinghoved :

Nucula nucleus L. var. Hanleyi WiNckW. Yoldia glaberrima v. Münst.
Nordamerika (Maryland):

Nucula proxima SAY

Yoldia laevis $\mathrm{S}_{\mathrm{AY}}$ 
Klintinghoved:

Abra angulosa ReN.

Panopaea Ménardi Deshayes

Thracia ventricosa PHш.

Dentalium (Antale) vitreum Sснвӧт.

Pyrula simplex BEYR.
Nordamerika (Maryland) :

Abra marylandica GLenN

Panopaea Whitfieldi DALL

Thracia Conradi Couthou Y

Dentalium cáduloide DALL

Pyrula Harrisi MART.

Det har Interesse i denne Forbindelse at nævne, at KAUtsky (49 p. 220) anfører ialt 15 Arter fra Nordamerika, deraf 13 fra Maryland og 2 fra Florida, hvorimellem ogsaa en Del af de ovenfor nævnte Arter, der i større eller mindre Grad kan siges at minde om Former fra Hemmoor.

Inden vi forsøger at drage Slutninger i Forbindelse med saadanne Former, der muligvis er identiske Arter i de to Omraader, skal her kort gøres Rede for de Resultater, som DALL (19) er naaet til ved Studiet af de østamerikanske miocæne Faunaer.

Ved en Sammenligning mellem Østkystens forskellige miocæne Faunaer konkluderer DALL bl. a., at Tilstedeværelsen af de boreale, tempererede og subtropiske Faunaer i Miocænet og deres Fordeling maa forklares ved lignende Strømme i Atlanterhavet som i Nutiden; der fandtes en kold nordlig og en varm sydlig Strøm, den miocæne Golfstrøm.

Ved at støtte sig til Arter, der baade forekommer ved Nordamerikas Østkyst i Chesapeake Serien og i Nutiden slutter DALL bl. a. (19 p. CXLIX): "The temperature conditions governing the fauna of the Maryland Chesapeake were those of the temperate rather than the boreal or subtropical faunas of the present coast.«

Ved en Sammenligning med europæiske Miocænfaunaer i den Udstrækning, det daværende Kendskab til dem tillod det, kommer DALL endvidere til det vigtige Resultat, som ikke kan siges at være omstødt siden, at Faunaerne i Nordeuropa er mindre boreale og har levet i varmere Vand end Chesapeake Seriens marine Fauna, selv om Marylands Chesapeake harmonerer bedre med de nordeuropæiske Faunaer end med de sydeuropæiske.

I Forbindelse med Hemmoor Faunaen, hvorfra KaUtsky, som omtalt, fremdrager 15 Parallelformer til nordamerikanske Faunaer slutter denne Forfatter bl. a. (49. p. 221):

"Die Beziehungen der Fauna der nordamerikanischen Ostküste zu jener von West-Frankreich sind - obwohl ebenfalls bemerkbar bedeutend schwächer als die zum Nordseebecken. Dies erfordert zwischen Maryland und dem Nordseebecken eine Meeresverbindung nördlich von England. Das nordatlantische Festland mit seinen miocänen Braunkohlenbildungen (SuEss) war, wie dies die zahlreichen Basaltergüsse bezeugen, im Zerbrechen, und in dem so entstandenen Archipel konnte leicht ein solcher Faunenaustausch stattfinden." 
Efter dette skal vi gaa over til en Vurdering af de anførte Arter.

Der er som omtalt under Beskrivelserne i den palæontologiske Del gjort opmærksom paa, at en Del af de anførte Former paa begge Sider af Atlanterhavet muligvis er identiske, selvom man ikke kan komme til fuld Sikkerhed paa dette Punkt. Antager man imidlertid, at det kan forsvares at sammenfatte enkelte af Arterne (til Eksempel skal jeg anføre, at jeg til saadanne Arter er tilbøjelig til at regne Yoldia laevis, Thracia Conradi og Panopaea Whitfieldi med deres europæiske Paralleler og endvidere om ikke alle, saa dog en Del af de af KAUtsky (49) anførte Arter), er efter min Mening den eneste sikre Slutning deraf den, at disse Formers Tilstedeværelse paa begge Sider af Atlanterhavet fordrer en $\mathrm{Hav}$ forbindelse imellem de to Omraader før eller paa det Tidspunkt, da Aflejringen fandt Sted. Eller, hvad der iøvrigt er det samme, at de to Omraader stod i Forbindelse med et tredie Hav, der eventuelt kan betragtes som Udgangsomraade for Arterne ${ }^{1}$ ). I den Omstændighed, at enkelte Arter muligvis forekommer paa begge Sider, ligger saaledes ikke nogen Begrundelse for Antagelsen af en "Faunenaustausch", idet jeg derved forstaar en Udveksling, der fører til en decideret Blandingsfauna som f. Eks. den nedremiocæne Fauna fra Ungarn. Det er derfor efter min Mening ikke tilraadeligt i denne Sammenhæng at tale om et nordatlantisk Fastland, da et saadant maa anses for ret problematisk og endvidere ikke kan siges at være nogen som helst Forudsætning for samme Arts Tilstedeværelse paa begge Sider af Atlanterhavet.

Søger vi en Forklaring paa den Mulighed, at vi i Miocænet forefinder samme Art baade i Maryland og i Nordsøbækkenet, er det vigtigt at lægge Mærke til DALL's Slutninger m. H.t. Strøm- og Klimaforhold langs Nordamerikas Østkyst under de miocæne Aflejringers Dannelse ${ }^{2}$ ). Som Følge af, at de miocæne Faunaer langs den nævnte Kyst havde en lignende Fordeling m. H.t. boreale og tempererede Former, som den, vi i Nutiden træffer langs Kysten (selvom det ikke var en nøjagtig Kopi af Nutiden, da Grænsen mellem Faunaerne var forskudt længere mod Syd), antager DALL (19) med god Ret lignende Strømforhold i Atlanterhavet langs Nordamerikas Østkyst, som dem, vi finder i Nutiden. Det vil med andre Ord sige, at den kolde Nordstrøm begunstigede den koldere Faunas Fremtrængen forholdsvis langt mod Syd; Marylandfaunaen maa saaledes antages i væsentlig Grad at have staaet under Indflydelse af Nordstrømmen, Floridas Fauna derimod ikke.

1) Vi ser her bort fra den Mulighed, at samme Art skulde kunne opstaa samtidig paa flere Steder, da en saadan Forklaring i dette Tilfælde forekommer mig for søgt.

${ }^{2}$ ) Naar der her og i det folgende tales om "fælles Arter" og "Fællesformer", maa man stadig huske paa, at det endnu ikke kan anses for at være endeligt bevist, at der virkelig er Tale om samme Art, idet tilstrækkeligt Sammenligningsmateriale ikke har foreligget ved Bestemmelserne; der burde saaledes egentlig anvendes et Udtryk som: „Arter, der sandsynligvis er identiske", eller f. Eks. "Parallelformer". 
Ser vi nu paa Fællesformernes Udbredelse langs Kysten (vi kan i denne Forbindelse ogsaa medregne de af Kautsky (49 p. 220) nævnte Former, er der en Ting, der straks falder i Øjnene, den nemlig, at Fællesformerne næsten udelukkende findes i Maryland, fra Florida nævner Kautsky kun to Former. Da Fællesformernes Antal saaledes er størst i Maryland, er der ogsaa større Chance for, at der imellem dem findes Arter virkelige identiske med Nordsøbækkenets, end Tilfældet er, naar man sammenligner med Florida.

Idet vi erindrer det ovenfor anførte om Klima- og Strømforhold, forekommer det mig i dette Tilfælde, at de samme Arters Udbredelse til baade Maryland og Nordsøbækkenet forklares bedst ved, at der er Tale om Repræsentanter for nordlige Dyresamfund, der samtidig har stor geografisk Udbredelse. M.a. O. : „Fællesformerne« har haft deres naturlige Udbredelsesomraade i de nordlige Dele af det miocæne Atlanterhav, hvorfra de er vandret sydpaa paa hver Side langs med Europas og Nordamerikas Kyster, ganske i Lighed med, hvad man i Nutiden kan iagttage m. H.t. nordiske Arters Udbredelse til Nordamerika (Sars 98, Brögger 11) ${ }^{1}$ ). Antallet af Arter, der i Nutiden er fælles paa begge Sider af Atlanterhavet, aftager mod Syd. Der findes saaledes ikke Arter fælles for Middelhavsfaunaen og de sydvesteuropæiske Faunaer under eet og Vestindiens Fauna, — bortset fra enkelte pelagiske Former og saadanne, der findes overalt langs med Atlanterhavets Kyster (Bucquoy, Dautzen berg et Dollfus 12 p. 754). Til dette har vi ogsaa en Parallel i Miocænet, idet Floridas og Vestindiens Fauna ikke har Arter fælles med Middelhavets Fauna fra den Tid (W. P. Woodring 129), da Lighederne mellem Faunaerne kun strækker sig til at omfatte de forskellige Genera.

Man vil heraf se, at der ikke er Tale om nogen "Faunenaustausch", som KaUtsky er tilbøjelig til at antage.

Naar jeg finder den her fremførte Forklaring naturligst, skyldes det bl. a. den Omstændighed, at der paa de to Sider af Atlanterhavet findes saa relativt faa Former, der med nogenlunde Sandsynlighed kan siges at være identiske; og endvidere dette, at Forholdene i Havet langs Nordamerikas Østkyst i Miocænet mindede saa meget om Nutidens, at man maa søge en Forklaring i Paralleler med Nutiden, uden at man behøver at tage sin Tilflugt til et nordatlantisk Fastland, hvorom man intet kan sige med Sikkerhed. De recente Faunaers Spredningsbiologi synes mig endvidere alt for utilstrækkelig undersøgte til, at man som Følge af de anførte Overensstemmelser i de to Omraaders Fauna kan antage eller dog støtte sig til en usikker Antagelse af et Fastland i Nordatlanten. Det eneste, man har Lov til at antage, er som nævnt Existensen af en Havforbindelse mellem de to Omraader $^{2}$ ).

1) Herved forstaas i Lighed med Nordmann (72 p. 211) arktiske eller boreale Arter.

${ }^{2}$ ) Paa samme Maade synes det mig, at der foreligger alt for svagt et Grundlag, naar 


\section{Østgrønland.}

Hvad der er sagt til Indledning ved Behandlingen af de nordamerikanske Faunaer som Sammenligningsgrundlag gælder her i endnu højere Grad. Det eneste Sted paa Grønlands Østkyst, hvorfra der kendes marint Tertiær, er Egnen ved Kap Dalton og Syd herfor (RAvN 1903 og 1933). Disse Aflejringers Alder er som Følge af utilstrækkeligt Fossilmateriale usikker, og RAvs har i Henhold til en vis Lighed med Londonbassinets Eocæn søgt at sammenligne de to Aflejringer og opstillet den Mulighed, at Kap Dalton Lagene er af eocæn Alder.

I Forbindelse med dette mener jeg, at det er paakrævet at gøre opmærksom paa, at der findes visse fælles Træk bl. a. med oligocæne og nedremiocæne Aflejringer i Nordeuropa; dog skal jeg forudskikke den Bemærkning, at det endnu ikke er muligt at komme til nogen sikrere Bedømmelse af Kap Dalton Faunaens Alder.

Blandt de meget faa sikkert bestemmelige Arter fra Kap Dalton findes Chenopus speciosus v. Scнцотн. sp., der maa henregnes til var. Margerini DE Koninck. Denne Form minder ganske vist om Chenopus Margerini de Kon. fra London-Eocænet (Starkie Gardner 29), men afviger fra denne ved Mundingens Bygning, idet Inderlæben skyder sig højere op paa Vindingerne (RAVN 1903), hvorved den slutter sig nærmere til de Former, der kendes fra de nordeuropæiske oligocæne og nedremiocæne Aflejringer.

Af de øvrige Fossiler har kun ganske faa kunnet artsbestemmes, saaledes at det er vanskeligt at bygge noget sikkert paa dem; kun skal her nævnes, at langt det største Antal af Slægterne har Repræsentanter i Oligocænet og Miocænet, det gælder bl. a. Nucula, Mytilus, Modiola, Cyprina, Astarte, Cryptodon, Tellina ${ }^{1}$, Donax, Natica, Fusus. Da de fleste af Formerne ikke kan bestemmes til Art, har de selvsagt ikke ret stor Værdi; dog mener jeg, at der er nogen Mulighed for at anbringe Kap Dalton Serien lidt højere oppe i det stratigrafiske System, specielt i Tidsrummet Mellemoligocæn-Nedremiocæn. I denne Sammenhæng skal atter mindes om de store Lighedstræk, der findes mellem Coeloma bicarinatum RAvN og Coeloma incarinatum nov. sp. fra Klintinghoved, og som efter min Mening er mere tungtvejende end Ligheden mellem Coeloma bicarinatum RAvN og Portunus incerta BeLL fra det engelske Eocæn (RAvN 1903 p. 139), saa meget mere, som der i dette sidste Tilfælde er Tale om to forskellige Slægter.

man som Følge af en vis Overensstemmelse i Genera i Middelhavet og Vestindiens Miocæn vil etablere en mere eller mindre udtalt Landforbindelse mellem de to Havomraader (Schaffer 101 I. p. 268, Kautsky 51 p. 62, Woodring 129 p. 430), og det er efter min Mening forkert at tale om Faunenaustausch (KAutsky 51 p. 62), idet i saa Tilfælde en langt større Overensstemmelse skulde have vist sig ikke blot i Genera, men ogsaa i Species.

1) Det af Ravn 1903, t. III, f. 10 afbildede Exemplar henregnet hertil kunde dog muligvis ogsaa repræsentere Skallen af en Thracia. 
For en Fuldstændigheds Skyld skal her endvidere anføres en Bemærkning af LöRenthey, fremsat ved Beskrivelsen af Coeloma (\% p. 243.). Ved Studiet af dette Genus kommer LőRenthey til den Anskuelse, at Udviklingsgangen gaar i den Retning, at de ældst kendte Former med forholdsvis glat Cephalothorax efterfølges af saadanne Former, hvis Cephalothorax med Tiden bliver mere og mere lobuleret, selv om en skarp Adskillelse ikke er mulig. Under Forudsætning af denne Antagelses Rigtighed $\left.{ }^{1}\right)$ slutter Lőrenthey (70 p. 242): "Auf Grund dieser allgemeinen Entwicklungstendenz der Gattung Coeloma müsste das in seinem Alter unbestimmte Coeloma Grönlands ins Mittel- oder Oberoligocän gestellt werden, da diese Form eine sehr ausgeprägte Gliederung besitzt《.

Vi kan sammenfatte Overvejelserne i Forbindelse med Kap Dalton Serien derhen, at der kan være nogen Rimelighed i at antage denne for at være yngre end Eocæn, nærmere betegnet, at man med Reservation kan henlægge dem til Tidsrummet Mellemoligocæn-Nedremiocæn. Det vil derfor være af Interesse, om Kap Dalton Serien ved Lejlighed kunde gøres til Genstand for en systematisk Indsamling, da dens nøjagtige Aldersbestemmelse er overordentlig værdifuld, dels ved Paralleliseringer paa begge Sider af Atlanterhavet, dels ved Bestemmelsen af Alderen af de Eruptivbjergarter, hvori den ligger indlejret.

\section{Palaeogeografiske Slutninger.}

Betragter vi Faunaen i Klintinghoved, især med Henblik paa de enkelte Arters geografiske Udbredelse, viser det sig blandt andet, at en Del Arter er fælles med jævnaldrende Aflejringer i Sydøsteuropa (i Wienerbækkenet og det ungarske Bækken), medens de ikke findes i tilsvarende Aflejringer ved Bordeaux, ganske i Lighed med hvad KAUTSKY (49. 50) fandt for Hemmoor Faunaen.

Disse Former er:

Cardium (Laevicardium) cingulatum GoLDF.

Thracia ventricosa PHIL.

Natica (Lunatia) helicina BRocchI

Natica (Polinices) submammillaris D'ORB.

Turritella Geinitzi SPEYER

1) Af Slægten Coeloma kendes foreløbig (Lörenthey 70 p. 241) 14 Arter, med C. incarinatum nov. spec, altsaa 15. 
Chenopus speciosus Schloth. var.

Murex (Haustellum) paucispinatus Roth v. TeLEGD

Murex (Muricantha) Deshayesii NysT

Nassa (Telasco) Schlotheimi BEYRICH

Surcula Steinvorthi SEMPER

Pleurotoma (Hemipleurotoma) Duchastelii Nyst

Af disse maa Turritella Geinitzi, Chenopus speciosus, Nassa Schlotheimi og sandsynligvis ogsaa Thracia ventricosa anses for typiske for Nordsøomraadet; endvidere maa Murex paucispinatus anses for at tilhøre en sydlig Fauna, hvortil ogsaa Cypraea amygdalum hører $\left.{ }^{1}\right)$. Hvorvidt de andre Former tilhører den sydlige eller nordlige Fauna, lader sig ikke med Sikkerhed afgøre.

Sammenholder vi dette med den Kendsgerning, at vi i det ungarske Aquitanien finder en Fauna, der afgjort viser Tegn paa nordisk Indvandring, idet ogsaa andre end de her anførte Former fra Nordsøbækkenet indgaar, maa, som ogsaa antaget af Roth v. Telegd, den logiske Konsekvens heraf blive, at der har eksisteret en Havforbindelse mellem de to Omraader.

Da en hel Del Former, bl. a. de ovenfor nævnte, ikke findes i de jævnaldrende Lag i Bordeaux-Bækkenet, og da der paa samme Tid efter GRIPP sandsynligvis ikke har eksisteret nogen Kanal mellem England og Frankrig, vil det være vanskeligt at tænke sig, at de sydlige Former kan være vandret saa langt mod Nord i Atlanterhavet som til Havet mellem Norge og England, idet man maa antage, at en ganske anden Fauna er vandret ind ad denne Vej. Det er derfor langt mere sandsynligt, at Udvekslingen skyldes, at der har eksisteret en Havforbindelse Ungarn-Wienerbækkenet-Mähren-Øvre-Schlesien-Posen -Nordtyskland-Jylland-Nordsøen.

En saadan Hypothese kunde maaske ved første Øjekast synes ret vovet; ser man imidlertid paa det skitserede Omraade, finder man indenfor dette en tredie Blandingsfauna af samme Alder som Klintinghovedfaunaen og de ungarske Faunaer, nemlig i KiтtL's Ostrau-Karwiner Miocæn.

Med Klintinghoved har dette, som allerede nævnt, bl.a. Genotia trochlearis fælles. Denne sjældne Forms Udbredelse kan ikke forklares bedre end ved Antagelsen af den skitserede Havforbindelse. Former som Turritella Geinitzi er vandret saa langt som til Siebenbürgen (KocH 54, 1894).

Endnu en Lokalitet bør nævnes, nemlig Xions Boringen, publiceret af Jentsch (47). I denne fandtes (under $100 \mathrm{~m}$ »Posener Ton« og $64 \mathrm{~m}$ Sand og Brunkul) fra $170 \mathrm{~m}$ Dybde til $230 \mathrm{~m}$ marint fossilførende Ter-

1) Denne Form findes ogsaa i Nedremiocænet i Bordeaux-Bækkenet. 
tiær bestaaende af finsandede kalkholdige Leraflejringer med Glimmer; under dette følger fra $230-240 \mathrm{~m}$ ældre Brunkulsdannelser. Fossilfundene har dog ikke kunnet give nogen sikker eller blot nogenlunde sikker Aldersbestemmelse af Lagene. At der kan være Tale om Nedremiocæn ligger dog indenfor Mulighedernes Grænse (Linstow 69 p. 105). Da »Posener Ton« højst sandsynlig maa henlægges til Pliocænet (P. G. Krause 1933, p. 65) og muligvis naar et Stykke ned i Miocænet, er der netop Mulighed for, at de underliggende marine Lag kan være af mellemeller nedremiocæn Alder.

Ser vi til Slut paa Havarmens Udviklingshistorie, maa vi sige, at den højst sandsynlig har elssisteret (muligvis med Afbrydelser) baade i Nedremiocæn og Mellemmiocæn (Kautsky 49, 50). Hvor længe den har eksisteret kan ikke siges med Sikkerhed. Saltaflejringerne ved Wieliczka stammer sandsynligvis fra Indtørring af visse Dele af det store Bækken, som Havet indtog før Tortonien. Efter af Posen-Bækkenet var blevet afsnøret fra Havet baade mod Nord og Syd, hvilket kan være sket i øvre Miocæn eller nedre Pliocæn, udfyldtes det i Løbet af Pliocæn med de mægtige Aflejringer af Posener Ton og ledsagende Lag af Kiseloolith eller Kaolinsand.

\section{Nedre-Miocænets Klima.}

Spørgsmaalet om de klimatiske Forhold, hvorunder Nedremiocænets Fauna levede, er ikke let at besvare med tilfredsstillende Nøjagtighed.

En af de Veje, ad hvilken man kan naa til nogen Erkendelse m. H. t. Havets Temperaturforhold, er at undersøge Udbredelsen af de Arter i Nutiden, der har fortsat deres Existens siden Nedremiocænet. Det viser sig da, at Nucula nucleus L., Abra angulosa Ren., (=A. prismatica Montagu) Cuspidaria (Cardiomya) costellata Desh., Natica helicina Brocc., Scaphander lignarius L., Bullinella cylindracea Penn. og Roxania utriculus BRocc. er saadanne Former.

Desværre siger de intet sikkert om det, vi søgte, idet de alle uden Undtagelse findes baade i Middelhavet og langs Spaniens, Frankrigs, Storbritanniens og Sydnorges Atlanterhavskyster; dog gaar Cuspidaria costellata og Bullinella cylindracea saa langt mod Syd som til Canarerne og Madeira. Alle de anførte Arter findes altsaa i Nutiden baade indenfor boreale og lusitanske Omraader.

Selv om denne Undersøgelse bragte lidet, peger de anførte Arter sammen med saadanne Genera som Solarium, Polinices, Pyrula, Cypraea 
(Zonaria), Tritonium, Murex, Tiphys, Leptoconus og Pleurotoma (Hemipleurotoma) afgjort i den Retning, at Klintinghovedfaunaen levede i et Hav med højere Temperatur end den, vi nu finder i Nordsøen. Vi maa derfor antage lignende Temperaturforhold, som vi i Nutiden finder dem ved Sydfrankrigs og Nordspaniens Kyster, selv om det er vanskeligt at sige noget sikkert, da man ikke kan afgøre, om hine Former opførte sig ganske paa samme Maade m. H. t. Temperaturen, som deres nærmeste nulevende Slægtninge.

Man maa dog ikke forestille sig Naturforholdene i Miocænhavet fuldstændig paa samme Maade som ved de sydvesteuropæiske Kyster, idet der højst sandsynligt ikke som her har været Tale om et aabent Hav; tværtimod maa man, som anført i Afsnittet om Palaeogeografien, regne med en Havarm, et Middelhav, der forbandt det daværende sydlige Middelhav med Nordsøen.

Det kan i denne Forbindelse være af Interesse at anføre Anskuelser om Miocænets Klima, fremsat af O. Jessen (48), paa Grundlag af Overvejelser over Forvitringsfænomener i de mellemtyske Bjerge sammenlignet med Forvitringsdækker i tropiske Egne. JESSEN kommer til det Resultat, at Klimaet i Mellemtyskland kan have været af noget lignende Art som Nutidens Klima i Florida med Sommerregntid og Vintertørtid; til Sammenligning anføres følgende Middeltemperaturer fra Florida: Foraar $21^{\circ}$, Sommer $28^{\circ}$, Efteraar $23^{\circ}$, Vinter $15^{\circ}$, Aarsgennemsnit $22^{\circ}$.

Denne Sammenligning kan dog efter min Mening ikke gennemføres alene af den Grund, at vi i Florida har et Omraade med subtropisk Regnskov og Savanne paa Østsiden af et Kontinent, mens der for Nordtysklands Vedkommende i Miocænet med en til Vished grænsende Sandsynlighed har været Tale om den vestlige Side af et Kontinent. $\mathrm{Vi}$ maa derfor sikkert antage et baade lidt koldere og desuden mere tørt Klima for den miocæne Nordsøs sydlige Omraader end det som i Nutiden findes i Florida, i Overensstemmelse med, at man i Nutiden langs Fastlandenes Vestkyster i tempererede-subtropiske Bælter finder de subtropiske Vinterregnsregioner med Makivegetation. 


\title{
Zusammenfassung.
}

\section{Marines Untermiocän im Klintinghoved auf der Insel Als.}

\author{
Ein Beitrag zur Lösung der Aquitanien-Frage.
}

\section{Einleitung.}

Im Kliff von Klintinghoved unweit Sønderborg sind seit Meyn $(1848,1851)$ fossilführende "Braunkohlenbildungen" - miocäner Glimmerton und Glimmersand - bekannt.

Auch Gotтsche $\left.\left(3^{7}\right)^{1}\right)$ sammelte an der genannten Stelle Fossilien, die ins geologische Museum zu Hamburg kamen. Später hat auch K. Gripp mit Erfolg die Fundstelle besucht und in seiner klassischen Arbeit über das Altmiocän des Nordseebeckens im Jahre 1915 die auf Seite $7-8$ des dänischen Textes angeführte Fauna veröffentlicht.

Auf Grund dieser Fauna schliesst Gripp auf Untermiocän für den Glimmerton, entsprechend dem Untermiocän der Vierlande bei Hamburg.

Die von Gripp veröffentlichte Fauna veranlasste eine Kritik Oppenherms (89). Als Antwort hierauf gab Gripp danach 1920 eine Ergänzung der Fauna, wobei er sich auf eigene Aufsammlungen stützt. Die auf Seite 8 genannten Formen werden für die Fundstelle als neu angeführt, und die gesamte Zahl der Spezies ist hiermit auf 27 gestiegen.

1932 wurden mein Bruder Otтo Sorgenfrei und ich durch den damaligen Abteilungsgeologen dr. phil. H.ØDum darauf aufmerksam gemacht, dass an der genannten Lokalität die besprochene interessante Fauna gefunden worden war.

Wir begannen darauf eine systematische Untersuchung der Schollen im Klintinghoved, jedoch ohne augenblicklichen Erfolg; erst im folgenden Jahre gelang es meinem Bruder durch Zufall eine fossilreiche Schicht zu entdecken.

Es wurden dann häufig Aufgrabungen und Aufsammlungen vorgenommen, letztmalig im Jahre 1937. Später stattete ich im März 1940 der Stelle einen kurzen Besuch ab, zu diesem Zeitpunkt hatte sich aber das Kliff durch niedergestürztes Material ziemlich verändert, u. a. waren die fossilführenden Schichten völlig zugeschüttet.

\section{Beschreibung der geologischen Verhältnisse.}

Klintinghoved liegt ungefähr 3,5 km SO von Sønderborg. Im Januar 1935 wurde eine Vermessung des Kliffprofils vorgenommen; auf Tafel I sind die Resultate dieser Vermessung niedergelegt.

Aus der Tafel geht klar hervor, dass es sich im westlichen Teil um eine im

1) Die Kursiv Nummern beziehen sich auf das Literaturverzeichnis. 
Diluvium eingelagerte Scholle handelt. Zwischen den Messpunkten 13 und 14 wurde ein Schurf von dem Fusse des Kliffs bis zum Meeresniveau angelegt, weil sich an dieser Stelle die fossilführenden Schichten befanden. Unter dem Glimmerton wurde hier Geschiebelehm angetroffen.

Die tertiären Schichten setzen sich weiterhin vom Punkte 28 bis 87 fort, sie werden durch Verwerfungen in drei Teilschollen geteilt; von Punkt 28 bis 55 wird die Scholle wie im westlichen Teil von Geschiebelehm unterlagert und ist ohne Zweifel die direkte Fortsetzung dieses westlichen Teiles, indem die beiden Teile höchst wahrscheinlich unter der Strandlinie miteinander zusammenhängen.

Der östlich von P. 55 gelegene Teil der Scholle wird bei P. 79 durch eine Verwerfung in zwei Teile geteilt, die ungefähr einen Meter gegen einander verschoben sind. Die liegenden Schichten können hier nicht beobachtet werden, doch handelt es sich ohne Zweifel um diluviale Ablagerungen. Die Scholle wird in diesem Abschnitt von Geschiebelehm und Schmelzwassersand überlagert.

Im östlichen Teil der Scholle zwischen den Messpunkten 79 und 85 liegen die Tonschichten ungefähr horizontal, verbiegen sich dann aber weiterhin zwischen P 85 und 87, sodass sie bei P 87 ungefähr senkrecht stehen.

Wenden wir uns der Deutung des Profils zu, so dürfte es klar sein, dass wir es mit einem losgerissenen Teil des tertiären Untergrundes zu tun haben.

Wie schon erwähnt, halte ich es für wahrscheinlich, dass die westliche fossilführende Scholle unter der Strandlinie mit der östlichen zusammenhängt. Weiter scheint eine gewisse Übereinstimmung in der Verteilung der Schichten östlich und westlich vom Punkte $60 \mathrm{~m}$ zu herrschen, indem wir auf beiden Seiten zu unterst Glimmerton, darüber Glimmersand und zu oberst wieder Glimmerton antreffen. Dieses deutet darauf hin, dass es sich auch hier um Teile einer ursprünglich einheitlichen Scholle handelt.

Der östlichste Teil der Scholle zwischen P 55 und P 87 wird durch die Verwerfung bei P 79 geteilt. Die Übereinstimmung in der Verteilung der Schichten östlich und westlich der Verwerfung ist jedoch eindeutig die gleiche, sodass man mit Sicherheit das Vorliegen einer ursprünglich einheitlichen Scholle annehmen darf.

Weiter darf man annehmen, dass die Verwerfung von dem Eistransport herrührt: die gefrorenen Schichtpakete verhielten sich wie eine Scholle starren Gesteins. Stellen die verschiedenen Teile von P 28 bis 87 ursprünglich ein Ganzes dar, so dürfte die spätere Trennung bei P 60 durch eine Verwerfung gleicher Art wie die bei P $79 \mathrm{zu}$ beobachtende hervorgerufen sein, nur sind die beiden Teilschollen von einander weiter entfernt.

Diese Hypothese hätte vielleicht durch etwaige Fossilien der verschiedenen Schichten in den besprochenen Teilschollen begründet werden können; dieses ist jedoch deshalb nicht möglich, weil Fossilien nur in der westlichen Scholle gefunden wurden.

Von grösstem Werte würde die Festlegung der primären Lagerstätte des Tertiärs sein; diese mit Sicherheit festzustellen, ist nicht möglich, wir müssen uns mit einer annähernden Festlegung begnügen.

Der Umstand, dass die Scholle in hohem Masse ihre ursprüngliche Textur bewahrt hat, spricht dafür, dass die Scholle nicht sehr weit vom Eise transportiert wurde. Denn obgleich die Schichtpakete sich in gewisser Weise wegen des gefrorenen Zustandes wie festes Gestein verhielten, würden sie, längerem Eistransport ausgesetzt, nach und nach ausgewalzt werden, wobei die ursprüngliche Textur verschwinden würde. Ferner wird Glimmerton von wahr- 
scheinlich untermiocänem Alter häufig an anderen Stellen in der Nähe in Bohrungen auf primärer Lagerstätte angetroffen (ØDUM 75).

Bei der Beantwortung der Frage, in welcher Richtung die Eisverfrachtung vorgegangen ist, ist es wichtig die Verbiegung der beim P 87 steil aufgerichteten Schichten, die nach und nach eine mehr horizontale Lage einnehmen, zu beachten. Meiner Meinung nach berechtigt diese Tatsache die Annahme einer Eisbewegung in annähernd Ost-West oder OSO-WNW-Richtung. Der ursprüngliche Ablagerungsort der Schollen muss demnach östlich oder südlich vom Klintinghoved gesucht werden. Das von Gotтsche (33, S. 3) erwähnte Vorkommen von Glimmerton beim Leuchtturm auf Kegnæs harmoniert hiermit.

Diese hier angenommene Richtung der Bewegung des Eises stimmt mit der gewöhnlich angenommenen Richtung des Wemmingbund-Gletschers überein, der u. a. die Stauchung des Wemmingbund-Randmoränenzuges und in Zusammenhang hiermit den Aufschub der interglazialen Eemschichten im Kliff von Stensigmose, $6 \mathrm{~km}$ WSW von Klintinghoved, bewirkte.

\section{Die tertiären Schichten.}

Bei Bescheibung des Profils wurde erwähnt, dass Glimmerton und Glimmersand vorkommen; die Verbreitung dieser Schichten wird auf der Profilskizze dargestellt.

Eine sedimentpetrographische Untersuchung ist nicht vorgenommen. In diesem Zusammenhang kann ich jedoch auf Helge Gry's Untersuchung des Glimmertones hinweisen (1935, Seite 45). Diese Untersuchung wurde in Zusammenhang mit der petrographischen Analyse der Bohrproben von den Langbrogaard-Bohrungen vorgenommen. Nach Helge Gry stehen die zu oberst in diesen Bohrungen angetroffenen miocänen Sedimente dem Glimmerton im Klintinghoved in der Korngrössenverteilung wie im Mineralinhalt nahe. Die Hauptkorngrösse der sandigen Teile liegt bei $0,{ }_{1} \mathrm{~mm}$ und die der tonigen bei $0,05 \mathrm{~mm}$. Der Glimmersand besteht hauptsächlich aus Quarz, dazu bedeutenden Mengen von Glimmer, namentlich Muskowit und grünem Glimmer. Bei Abnahme der Korngrösse nimmt die Menge des Glimmers auf Kosten des Quarzes zu. Ausser den angeführten Bestandteilen findet man auch kleine Pyritkonkretionen und Glaukonitkörnchen.

Ich möchte noch hinzufügen, dass der Glimmerton gewöhnlich ein schwarzes Aussehen hat; der erdfeuchte Zustand verleiht ihm einen bräunlichen oder grünlichen Farbenton. Der Glimmersand ist sehr hell, stellenweise beinahe weiss, in gewissen Zonen kommen Ausscheidungen von Eisenverbindungen vor, wodurch der Sand gelblich-rötlich gefärbt wird.

Zum Mineralinhalt ist ausserdem zu bemerken, dass besonders zwischen den Messpunkten 60 u. 80 Gipskristalle von mehreren Zentimeter Grösse im Glimmerton vorkommen. Der Gips ist als neugebildetes Mineral anzusehen; übrigens wird der Gips schon von Meys erwähnt ( 77 ).

Die zwischen den Punkten 0 und 20 aufgefundenen Fossilien beweisen die marine Entstehung der Tone. Der Umstand, dass anderswo in dem Glimmerton keine Fossilien gefunden wurden, könnte durch wirkliches Fehlen dieser erklärt werden, aber es ist wahrscheinlicher anzunehmen, dass auch hier einst Fossilien im Sediment eingelagert waren; sie fielen aber verhältnismässig schnell der Schwefelsäureverwitterung des Pyrits zum Opfer, worauf der Gips, der an vielen Fossilien zu beobachten ist, hinweist. Die Häufigkeit der Gipskristalle zwischen P 60 und 80 deutet ferner darauf hin, dass die Pyritverwitterung hier infolge der guten Durchströmungsverhältnisse des Sicker- 
wassers in den über-und unterlagernden Sandschichten ihr Ende erreicht hat. Deshalb finden wir hier keine Fossilien.

Auch der Glimmersand ist marin. Zwar findet man keine Weichtierschalen, da sie vom Sickerwasser aufgelöst sind. Wo die ausgeschiedenen Eisenverbindungen aber die Sandkörner zu losem Gestein zusammenkitten, bezeugen Abdrücke, dass die Molluskenschalen einst abgelagert wurden. Eine genaue Bestimmung kann natürlich nur im Einzelfall vorgenommen werden. Folgende Fossilien wurden bestimmt:

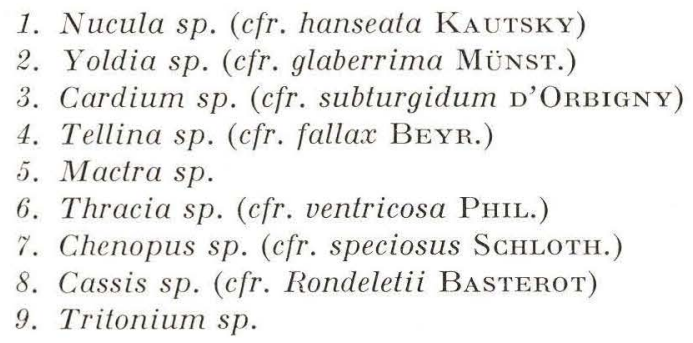

Eine genaue Altersbestimmung des Glimmersandes ist nach diesen Fossilien nicht möglich. Für sie alle gilt aber, so weit wie die mangelhaften Bestimmungsmöglichkeiten ein Urteil gestatten, dass sie mit Ausnahme von Mactra sp. auch im Glimmerton gefunden zu sein scheinen. Es muss deshalb dem Glimmersand ein ähnliches Alter wie dem Glimmertone zugeschrieben werden, eine Annahme, die an Wahrscheinlichkeit gewinnt, wenn die bei einer allgemeinen Betrachtung zu beobachtenden engen Beziehungen zwischen beiden Sedimenten in ihrer Verteilung ins Auge gefasst werden. Jedenfalls lässt sich keine faunistische Trennung vornehmen.

\section{Palaeontologischer Teil.}

\section{Lamellibranchiata.}

\section{Lissochlamys cfr. Gérardi $\mathrm{N}_{\mathrm{s}} \mathrm{t}^{1}$ )}

(Tafel IV, Fig. 1).

Ein kleines Exemplar einer rechten Klappe liegt vor; Höhe und Länge sind je $3 \mathrm{~mm}$. Das Schälchen scheint auch unter der Lupe fast glatt mit schwachen konzentrischen Streifen zu sein, es ist ein wenig schief ausgebildet.

Der von RAvn beschriebene Pecten könnte vielleicht auch dieser Spezies zugerechnet werden:

Miocän: Norddeutschland (u-m-o)²), Holland, Belgien (Anversien).

Pliocän: England, Belgien.

\section{Pecten sp.}

Nur ein kleines Schalenbruchstück mit wellenförmigen Radialstreifen liegt vor. In den Radialfurchen schwache knotenförmige Bildungen.

\section{Arcoperna sericea B r on n}

Zwei doppelklappige Stücke, das grösste in Form eines Steinkernes mit Schalenresten, das zweite eine Jugendform, 2,8 mm hoch. Das Schaleninnere

$\left.{ }^{1}\right)$ Die Synonymenlisten, Familien- und Genusnamen sind im dänischen Text aufgeführt.

2) $\mathrm{u}=$ unter, $\mathrm{m}=$ mittel, $\mathrm{o}=$ ober. 
ist perlmutterglänzend, die Oberfläche trägt zahlreiche feine Radialstreifen. Die Dimensionen sind:

$\begin{array}{rcr}\text { Höhe } & \text { Breite } & \text { Dicke } \\ 22,8 & 16,8 & 13,5 \mathrm{~mm} \\ 2,8 & 1,9 & 1,5 \mathrm{~mm}\end{array}$

Im Verhältnis gleichen sie den von Nyst, Hoernes und NørregaArd beschriebenen Schalen

Miocän: Dänemark, Norddeutschland (u-m), Wiener Becken, (2 Medit.), Italien, (Helvétien).

Pliocän: England, Belgien, Italien.

\section{Nucula hanseata Ka utsky}

(Tafel IV, Fig. 2, 3).

15 zweiklappige Exemplare und ausserdem zahlreiche Schalenbruchstücke.

Die Schale ist stark gewölbt und stark ungleichseitig; der vordere Dorsalrand ist etwa dreimal länger als der hintere Dorsalrand, die beiden Teile des Dorsalrandes treffen sich unter einem Winkel von etwa $115^{\circ}$.

Der Vorderrand ist stark, der Ventralrand dagegen in seinem vorderen Teil ziemlich schwach gebogen bis ungefähr lotrecht unter dem Wirbel, wo eine leichte Knickung des Randes angedeutet ist; von hier verläuft der Ventralrand als ungefähr gerade Linie bis zum hintersten Dorsalrand.

Vor dem Wirbel wird eine Pseudolunula auf jeder Schale von einem durch Knickung der Zuwachsstreifen hervorgerufenen Bogen begrenzt. Dieser letzte wird ausserdem in den meisten Fällen von einer Reihe von Poren in der Schalenoberfläche markiert. Die Poren müssen als Perforierung der Schale, die sich in den Zahngrübchen des Schlosses fortsetzt, erklärt werden (SoRgEnfrei 1937).

Die Pseudolunula wird von einer vom Wirbel bis zum Vorderrand verlaufenden schwachen Depression umgrenzt.

Hinter dem Wirbel liegt die der Pseudolunula entsprechende Area, die im Verhältnis zu der übrigen Oberfläche der Schale eingesenkt ist. In der Furche der die Area umsäumenden Falte findet man wie an der Grenze der Pseudolunula eine Porenreihe. Die Perforierung ist am stärksten in der Nähe des Wirbels ausgeprägt. Dies gilt auch für die Pseudolunula. Das bei der Beschreibung des Ventralrandes erwähnte gerade vordere Stück markiert den Teil der Schale an der Area, welcher ein Analogon der schwachen Depression an der Pseudolunula ist.

Die Zuwachslinien stehen oft in relativ starkem Relief, die Schalenoberfläche wird von hellen und dunklen Farbenbändern verziert.

Bei einer einzigen Schale (Tafel IV, Fig. 3) konnte das Schaleninnere beobachtet werden. Der Ventralrand dieses Exemplares ist jedoch abgebrochen, und ebenso fehlt der Schalenteil des hintersten Schliessmuskels. An anderen Schalenbruchstücken kann man sehen, dass der Rand innen glatt ist.

Das Schloss trägt vorne 21 spitze längs gefaltete Zähnchen; da der Hinterrand abgebrochen ist, kann die Zahl der Zähne hier nicht festgestellt werden. Die Area ligamentis ertreckt sich vom Wirbel bis zum zehnten Zahn, vom Wirbel aus gerechnet.

Die Eindrücke der Fussmuskeln sind schön zu beobachten. Vom Rücken der Schale verläuft ein schmaler Eindruck $\left.(1)^{1}\right)$ von der Gegend des Vorderrandes der Area ligamentis in lateraler Richtung. Weiter vorne findet man näher dem Ventralrand einen breiteren medianen Fussmuskeleindruck (musc. retract.

1) Die Nummern beziehen sich auf Tafel IV, Fig. 3. 
pedis posterior (2)), darunter einen kleineren runden (3) und einen punktförmigen zentralen Eindruck (m. elevator pedis (4)). Ein wenig vor diesen liegen in einem Bogen, der sich zum vorderen Schliessmuskeleindruck erstreckt, 5 punktförmige Fussmuskeleindrücke $(m . m$. retractores et protractores pedis anterior (5-9)).

Miocän: Norddeutschland (m), Belgien (Boldérien).

\section{Nucula nucleus L. var. Hanleyi W in $\mathrm{ck}$ w $0 \mathrm{rth}$}

3 zweiklappige Exemplare, 3 linke und eine rechte Klappe.

Die Schalen stimmen mit Kautsky's Abbildungen überein. Betreffs der Skulptur sei gesagt, dass die Radialskulptur nicht so hervortritt wie die konzentrischen Streifen.

Nach Schenck steht N. nucleus L. var Hanleyi der N. nucleus L. sehr nahe, weicht aber durch kleineren Schlosswinkel und „dunkle« Radialstreifen von dieser ab. Die Exemplare vom Klintinghoved haben ein mehr dreieckiges Aussehen als das von Schenck skizzierte Stück. Abbildungen zeigen, dass die N. proxima SAy aus Maryland (Maryland Miocene; p. 398, t. CVIII, f. 5-6) der $N$. nucleus var. Hanleyi nahe steht, dasselbe gilt vielleicht auch von N. Benoisti Cossmann et Peyrot (Act. Linn. LXVI; p. 211. t. V., f. 34-37).

Miocän: Norddeutschland (m).

\section{Leda (Jupiteria) pygmaea $M$ ü nst.}

Von dieser Art liegen vor: eine Doppelklappe (Länge 3,0 mm, Höhe 2,2 mm, Breite 1,6 mm), eine linke und eine rechte Klappe.

In der Literatur wurde diskutiert, wieweit L. tenuis und L. Philippiana mit dieser Art identisch seien. Weinkauff trennt die pliocänen und recenten Formen von L. pygmaea und rechnet sie zu ein und derselben Art, für welche er den Namen Leda tenuis PhiLippi beibehält.

Ohne irgendwelche Begründung führt Kautsky die als L. tenuis und L. Philippiana beschriebenen Formen in seiner Synonymenliste an. Da mir Vergleichsmaterial fehlt, kann nicht entschieden werden, ob KaUtsky's Angaben berechtigt sind, der Vollständigkeit halber sind diese Formen in der Synonymenliste in Klammern angeführt.

Oligocän : Dänemark (o), Norddeutschland (m-o).

Miocän: Dänemark, Norddeutschland (u-m-o).

Pliocän(?): England, Belgien.

\section{Yoldia glaberrima $M$ ü nst. (Tafel IV, Fig. 4).}

15 mehr oder weniger beschädigte Exemplare sowie 4 zweiklappige Stücke.

An einer beschädigten linken Klappe konnte das Innere beobachtet werden. Im Zusammenhang hiermit muss besonders gesagt werden, dass das Schaleninnere eine von dem Wirbel schräg nach vorne verlaufende, schwache rinnenförmige Vertiefung besitzt, die sich zum Ventralrande erstreckt. Diese Rinne kann auch bei der Yoldia laevis $\mathrm{S}$ AY, deren verwandtschaftiche Beziehungen zu Y.glaberrima von KaUtsky hervorgehoben sind, beobachtet werden (Maryland Miocene; p. 397, t. CVIII, f. 3 -4).

Ich bin geneigt, diese beiden Formen als identisch anzusehen, da sie scheinbar in den meisten Merkmalen übereinstimmen.

Oligocän: Dänemark (o), Norddeutschland (o).

Miocän: Dänemark (m), Norddeutschland (u-m) Holland. 
8. Arca sp. cfr. decussata N y st et West.

Ein Fragment einer kleinen linken Schale einer Arca ist gefunden; der Schlossrand ist erhalten.

Die Skulptur ähnelt der der A. decussata; auf Grund des mangelhaften Erhaltungszustandes ist eine zuverlässige Bestimmung des Stückes nicht möglich.

Die Arca decussata ist in oligocänen (unter, mittel, ober?) Ablagerungen aus Norddeutschland und Belgien bekannt.

\section{Limopsis aurita B rocchi}

(Tafel IV, Fig. 5, 6).

Zahlreiche Exemplare von Schalen dieser schönen Muschel liegen vor, die wohl das häufigste Fossil innerhalb der Lamellibranchiaten des Glimmertones ist.

Eine gute Beschreibung der Oberflächenskulptur gab Harder. Da dieser Verfasser die Kleinheit der oligocänen Formen gegenüber der Grösse der miocänen hervorhebt und in diesem Zusammenhange auch die geringere Schiefe der ersteren betont, soll auch hier ein »Schiefheitsquotient«im Sinne Harder's von einigen Klintinghoved-Exemplaren gegeben werden.

Der "Schiefheitsquotient« ist gleich dem Verhältniss der längsten und kürzesten Ausdehnung der Schale in der Dorsoventralen gemessen. Die Schiefe wird durch die kräftigere Entwicklung des vorderen Teiles der Schale bedingt. Die Linien, von denen die Rede ist, schneiden einander in einem ungefähr rechten Winkel.

In der Tabelle sind die längste und kürzeste Achse in $\mathrm{mm}$ ausgedrückt und mit l. und k. bezeichnet. Schiefheitsquotient gleich $\frac{1}{\mathrm{k}}$.

\begin{tabular}{c|c|c|c|c|c|c|c|c|c}
\hline $\begin{array}{c}\mathrm{l} . \\
\mathrm{k} .\end{array}$ & 1,70 & 2,8 & 3,3 & 4,6 & 5,0 & 5,0 & 5,4 & 5,6 & 6,5 \\
4,65 & 2,7 & 3,0 & 4,3 & 4,5 & 4,6 & 5,0 & 4,9 & 5,8 \\
\hline $\mathrm{l}$ & 1,03 & 1,04 & 1,10 & 1,07 & 1,11 & 1,09 & 1,08 & 1,14 & 1,12 \\
\hline
\end{tabular}

Harder führt für die Exemplare von Aarhus einen Durchschnitt für $\frac{1}{k}$ von 1,09 an. Die grösste von Harder abgebildete Schale hat bei einer Höhe von $7,4 \mathrm{~mm}$ einen Schiefheitsquotient von 1,10. Im Gegensatz hierzu erwähnt Harder, dass miocäne Schalen aus Esbjerg einen durchnittlichen Wert dieser Grösse von 1,13 aufweisen.

Die für die Klintinghoved-Exemplare angeführten Werte von $\frac{1}{\mathrm{k}}$ verdeutlichen aber, 1., dass der Schiefheitsquotient für Schalen gleicher Grössenordnung bedeutend schwankt, und 2., dass dieser Quotient mit der Grösse der Schale zunimmt.

Diese Art der Gesetzmässigkeit kann einem nicht wunder nehmen, da sie am natürlichsten ist.

Der von HARDER angeführte Quotient harmoniert sehr gut mit dem der Sehalen derselben Grössenordnung vom Klintinghoved. Ob Harder's Varietät 
aufrecht erhalten werden kann, ist nach meinen obigen Ausführungen meiner Meinung nach zweifelhaft. Die von KAUTSKy unterschiedene Varietät ist ohne Zweifel mit Harder's identisch, und der Name muss aus Prioritätsgründen aufgegeben werden, falls man die Varietät aufrecht erhalten will, was wie erwähnt, nicht empfohlen werden kann.

Oligocän : Dänemark (o).

Miocän: Dänemark (m-o), Norddeutschland (u-m-o), Belgien (Anversien) Westfrankreich (Tortonien) und Italien (Helvétien, Tortonien).

Pliocän: England, Belgien, Italien.

10. Astarte concentrica Goldf.

(Tafel IV, Fig. 8).

$\mathrm{Zu}$ dieser Art wird eine rechte Schale mit einer Höhe von 5,7 mm, Länge $4,8 \mathrm{~mm}$ und Breite $1,7 \mathrm{~mm}$ gerechnet.

Das Exemplar stimmt gut mit Kautsky's Abbildung überein, der Winkel am Dorsalrand ist jedoch ein wenig grösser.

Kautsky rechnet die von Ravn beschriebene A. concentrica zu der var. gracilis Münster, die zahlreichere konzentrische Streifen trägt. Da RAvN aber mitteilt, dass die von ihm beschriebene A. concentrica "gewöhnlich dichter stehende konzentrische Streifen als A. Kickxi Nyst trägt«, darf man wohl annehmen, dass zwischen den von RavN beschriebenen Exemplaren auch Formen mit mehr grober Berippung auftreten, die, wie Ravn annimmt, zu der A. concentrica gehören.

Oligocän: Dänemark (o), Norddeutschland (o).

Miocän: Dänemark (m), Norddeutschland (u-m), Holland.

\section{Astarte pygmaea v. M ünst. sp.}

Eine rechte Schale mit beschädigtem Schlossrand liegt vor; auch der hintere Teil der Schale ist ein wenig beschädigt.

Das Exemplar passt gut zu der von RAvn gegebenen Beschreibung. Der Ventralrand ist krenuliert.

Höhe und Länge 2,8 mm, Breite $0,8 \mathrm{~mm}$.

Oligocän: Dänemark (o), Norddeutschland (u-m-o).

\section{Isocardia sp.}

Ein Schalenbruchstück mit erhaltenem Schlossrand gehört zu diesem Genus. Es ist von der Schwefelsäureverwitterung so zerstört, dass eine genaue Bestimmung nicht vorgenommen werden kann.

\section{Cardium (Laevicardium) subturgidum d'0 r b ig n y}

(Tafel IV, Fig. 7).

3 Doppelklappen, 3 linke und 4 rechte Schalenhälften sind gefunden, ausserdem liegen mehrere Bruchstücke vor.

Dieses Cardium schliesst sich eng an C. cyprium Brocchi (Kautsky 49 p. 37 , t. 4, f. 7) an, zu welcher Art Kautsky auch die unter Cardium comatulum Bronn (RAvn 1907, p. 276, t. 1, fig. 25) von Ravn beschriebenen Formen rechnet. Bogsch ( 7 , p. 53) folgt hierin KaUtsky nicht.

C. subturgidum weicht nach KAUTsky durch die verhältnismässig grössere Länge von dem C. cyprium (= C. fragile HoErnes) ab. Die Schalen vom Klin- 
tinghoved sind aber nicht weniger gewölbt, als es bei dem C. cyprium der Fall ist.

Oligocän: Deutschland (m).

Miocän: Deutschland (u-m), Belgien (Anversien), Westfrankreich? (Tortonien).

14. Cardium cingulatum Gold f.

Eine Anzahl Schalenbruchstücke und eine linke Schale gehören dieser Art an. Olig o cän: Norddeutschland (u-m-o).

Miocän: Dänemark, Norddeutschland (u), Wiener Becken (1 Medit.), Ober Schlesien, Ungarn (Aquitanien).

\section{Meretrix (Cordiopsis) incrassata S ow. var. flexicostulata Ka u tsky}

(Tafel IV, Fig. 9, 10).

Ein doppelklappiges Exemplar in schönem Erhaltungszustand, aber in ursprünglicher Lage durch Konkretionsbildung zusammengekittet, und ausserdem eine rechte Klappe und der grösste Teil eines zweiten doppelklappigen Exemplares liegen vor.

Die Exemplare stimmen gut mit Kautsky's Beschreibung und Abbildung überein, weichen aber unwesentlich durch geringere Höhe ab. Übrigens ist es fraglich, ob Kautsky's Varietät aufrechterhalten werden kann, da die Meretrix incrassata nach den Literaturangaben sehr variieren kann.

Das von Roth v. Telegd abgebildete Exemplar unterscheidet sich durch die grössere Länge von den Klintinghoved-Formen. Dass zwischen den Egerer Formen aber auch solche sich befinden, die ungefähr demselben Typ angehören wie diese, zeigt die folgende Zusammenstellung der Breite, Höhe und Länge einiger ungarischen Formen (nach Roth v. Telegd) und des doppelklappigen Stückes vom Klintinghoved (Angaben in mm). Die letzte Abteilung des Schemas zeigt die Verhältnisse Breite: Höhe: Länge.

\begin{tabular}{l|c|c|c|c|c}
\hline & Breite & Höhe & Länge & Br. : H. : L. \\
\hline Exemplar vom Klintinghoved. & 25 & 42 & 46 & $0,54: 0,91: 1$ \\
\hline $\begin{array}{l}\text { Exem- } \\
\text { plare aus } \\
\text { Ungarn. }\end{array}$ & $\begin{array}{c}\text { Zwei runde Varietäten } \\
\text { von Eger. }\end{array}$ & - & 31 & 34 & $-: 0,91: 1$ \\
\hline $\begin{array}{l}\text { Durchschnitt von 5 Exp. } \\
\text { Lange Varietät. }\end{array}$ & 24,5 & 34 & 36 & $0,68: 0,94: 1$ \\
\hline
\end{tabular}

Meretrix incrassata Sow. trifft man in folgende Ablagerungen:

Oligocän: Beinahe ganz Europa.

Miocän: Dänemark, Norddeutschland (u?-m), Holland, Belgien (Boldérien), Ungarn (?) (Aquitanien).

16. Cyprina sp.

Ein kleines Schalenbruchstück, das ohne Zweifel zu Cyprina gehört, ist gefunden.

\section{Tellina fallax Beyrich}

(Tafel IV, Fig. 11, 12).

9 Doppelklappen rechne ich zu dieser Art.

Da in der Literatur die Möglichkeit diskutiert wird, dass diese Form mit der pliocänen $T$. Benedenii identisch ist, wird im folgenden eine ausfürlichere Beschreibung des Schalenbaues der Exemplare vom Klintinghoved gegeben. 
Die Schale ist dreieckig-gerundet. Das Hinterende ist mehr zugespitzt als das Vorderende. Die Dorsallinie ist vor dem Wirbel ungefähr gerade, hinter ihm leicht konvex. Das Verhältnis Höhe:Länge ist ungefähr 1:1,6.

Die Schale ist glatt mit gewöhnlicher Zuwachsskulptur und mit dunklen und hellen konzentrischen Farbenbändern verziert.

Der hintere Teil der Schale ist ein wenig nach rechts gebogen, weshalb die linke Klappe ein wenig stärker gewölbt erscheint als die rechte. Vom Wirbel zum Hinterende verläuft längs des Dorsalrandes auf der Oberfläche eine mehr oder weniger deutliche Rinne. Auf der rechten Klappe findet man unter dieser Rinne eine breitere schwache Depression, die durch Verbiegung der Schale nach rechts bedingt ist.

Die Formel des Schlosses ist $\frac{\mathrm{L} \text { : C o C o (l) }}{\mathrm{D}: \text { o } \mathrm{C} \text { o } \mathrm{C} \mathrm{m} \mathrm{l}}$

Über dem vorderen Schliessmuskeleindruck befindet sich ein Fussmuskeleindruck. Unmittelbar unter dem Schlosse ein wenig nach vorne liegen dicht bei einander zwei kleine, schmale Muskeleindrücke.

Der tiefe Sinus geht bis zu einer vom Fussmuskeleindruck am vorderen Schliessmuskel verlaufenden lotrechten Linie und wird lotrecht unter dem zentralen Teil des hinteren Schliessmuskeleindruckes abgeschlossen.

Von der $T$. decipiens v. Koenen unterscheiden sich beide $T$. fallax und $T$. Benedenii dadurch, dass das Hinterende stärker nach rechts gebogen ist. Nach Kautsky soll wieder T. fallax sich von der T. Benedenii durch 1. grössere Länge, 2. grösseren Dorsalwinkel, 3. mehr zugespitztes Hinterende und 4. gerades Verlaufen des hinteren Dorsalrandes unterscheiden.

$\mathrm{Ob}$ alle Merkmale gleich konstant sind, konnte ich nicht entscheiden. Obgleich die Schalen vom Klintinghoved einen schwach konvexen hinteren Dorsalrand besitzen, habe ich sie zu T. fallax gerechnet, da diese Abweichung mir zu klein für eine Abtrennung von dieser Form schien.

Miocän: Dänemark, Norddeutschland (u-m-o) Holland, Belgien (Boldérien, Anversien).

\section{Abra angulosa $\mathrm{Ren}$. (=A. prismatica M ontag u $)$.}

(Tafel IV. Fig. 13, 14).

Ein kleines vollständiges Exemplar, zwei grössere, die ein wenig zerbrochen sind, und zwei leicht beschädigte rechte Klappen liegen vor.

Wie Kautsky erwähnt, stellt schon Weinkauff $A$. prismatica und $A$. stricta als Synonyme zu Abra angulosa.

Kautsky macht auf die Verwandtschaft zwischen A. marylandica (Maryland Miocene, p. 296, t. LXXVII, f. 10) und A. angulosa aufmerksam. Die aus Maryland beschriebene Schale hat eine Länge von $7 \mathrm{~mm}$, Höhe 4,5 $\mathrm{mm}$ und Breite 1,6 mm. Zum Vergleich seien die entsprechenden Messungen an dem kleinen Exemplar vom Klintinghoved gegeben und zwar: Länge $7 \mathrm{~mm}$, Höhe $4 \mathrm{~mm}$, Breite 1,7 mm. In Beziehung auf die Grössenverhältnisse stimmen die beiden Formen also gut miteinander überein.

Bei der Zeichnung der A. marylandica scheint man den Mantelsinus vergessen zu haben. Übrigens passt die Schale vollständig zu der Beschreibung von $A$. angulosa und darf warscheinlich hierher gerechnet werden.

Miocän: Norddeutschland (u-m-o), Holland, Belgien (Anversien) und Italien (Tortonien).

Pli ocän : England, Belgien, Italien.

Recent: Küsten des Atlantischen Ozeans von Norwegen, Grossbritannien, Spanien und Portugal, Mittelmeer. 


\section{Panopaea Ménardi D e s h.}

(Tafel IV, Fig. 15).

Zwei Doppelklappen, die ein wenig zerbrochen sind, sind gefunden.

Es handelt sich um dünnschalige Exemplare; sie sitzen auf Steinkernen, sodass sie nicht vollständig freigelegt werden konnten. Das Ligament ist an beiden Schalen erhalten.

Die Schalen gehören zweifellos zu Panopaea Ménardi und stimmen gut mit Hoernes Abbildung überein, unterscheiden sich aber durch einen etwas tieferen Mantelsinus. Hoernes macht darauf aufmerksam, dass der Mantelsinus an den Wiener Exemplaren bezüglich der Tiefe variiert.

P. Whitfieldi Dall aus Maryland (Calvert u. Choptank Formation) steht dieser Form nahe und ist vielleicht damit identisch (Maryland Miocene, p. 276, t. LXV f. 10)

Olig o cän: Italien (Tongrien).

Mi ocän: Dänemark (?) Norddeutschland (u-m-o), Holland, Belgien (Anversien), Westfrankreich (Aquitanien, Burdigalien, Helvétien), Wiener Becken (1 Medit. Grunder Sch. 2 Medit.) und Italien (Helvétien, Tortonien).

\section{Thracia ventricosa Phil.}

(Tafel IV, Fig. 16)

12 zweiklappige Exemplare.

Hierzu ist nichts zu bemerken, nur die von Kautsky erwähnte Verwandtschaft mit T. Conradi Couthouy möchte hervorgehoben werden. Vielleicht ist es dieselbe Form.

Miocän: Dänemark (m-o), Norddeutschland (u-m-o), Wiener Becken (2 Medit.), Italien (Tortonien), Ungarn (Aquitanien).

Pliocän: England, Belgien, Italien.

\section{Cuspidaria (Cardiomya) costellata Deshayes}

(Tafel IV, Fig. 17)

Ein zweiklappiges Exemplar, eine rechte und eine linke Klappe liegen vor.

Die Schalen stimmen gut mit NysT's Beschreibung überein, die rechte Klappe des grössten Exemplars hat eine Länge von $6,5 \mathrm{~mm}$ (die ursprüngliche Länge war etwa $7 \mathrm{~mm}$ da das Hinterende ein wenig abgerieben ist) und eine Höhe von 4,8 mm. Die Länge der zweiklappigen Schale ist $4,5 \mathrm{~mm}$, Höhe $3,0 \mathrm{~mm}$ und Breite 2,1 $\mathrm{mm}$.

Die beiden Schalenhälften sind verschieden gewölbt, die linke am stärksten; die rechte Klappe dagegen besitzt eine grössere Höhe als die der linken.

Die Skulptur ist eine verhältnismässig stark entwickelte Radialskulptur. Die Radialstreifen am hinteren Ende sind kräftiger ausgebildet; am vorderen Ende liegen sie dicht nebeneinander mit einem Zwischenraum von etwa derselben Weite wie die Breite der Radialstreifen. Dieser Zwischenraum nimmt gegen das Hinterende zu, wo die drei kräftigsten Radialrippen den skulpturierten Teil der Schale abschliessen. Die Schale wird danach in ein rohrförmiges Rostrum ausgezogen, das etwa ein Drittel der Schalenlänge einnimmt. Das Rostrum ist mit Zuwachsstreifen versehen, ausserdem findet man am Dorsalrand 2 oder 3 linienförmige Radialstreifen.

Die Zuwachsstreifen machen sich besonders in den leicht konkaven Zwischenräumen der Rippen bemerkbar.

Das Innere und der Schlossrand konnte nicht beobachtet werden. Nach Nyst besteht das Schloss aus einer Bandgrube und einem Schlosszahn. 
Miocän: Norddeutschland (u-m-o), Belgien (Boldérien) Westfrankreich (Tortonien).

Pliocän: Belgien, Süditalien.

Recent: Im Atlantischen Ozean, an den Küsten Norwegens, Grossbritanniens und der Kanarischen Inseln und an den Küsten des Mittelmeeres.

\section{Scaphopoda.}

22. Dentalium (Antale) vitreum Schröt.

Eine Anzahl Bruchstücke werden hierzu gerechnet.

In Ergänzung der allgemeinen Beschreibung, wie man sie in der Literatur findet, mögen folgende an den Klintinghoved-Exemplaren zu beobachtende Merkmale hervorgehoben werden.

An den älteren Schalenteilen findet man eine Andeutung von sehr schwacher Längsskulptur in Form sehr flacher Rippen, die vielleicht besser als Undulationen in der sonst völlig glatten und glänzenden Schalenoberfläche, deren Einförmigkeit nur von den Zuwachsstreifen gestört wird, bezeichnet werden.

Nach Sacco rechnet KaUtsky die in der Synonymenliste aufgeführten Formen zu D. (Antale) vitreum, da die miocänen Schalen im Gegensatz zu D. entale keinen Schlitz besitzen.

D. vitreum schliesst sich durch das Fehlen einer Skulptur und des Schlitzes an D. caduloide Dall (Maryland Miocene, p. 272, t. LXIV, f. 5) an, weicht aber durch die glänzende Schale von dieser Form ab.

Miocän: Dänemark, Norddeutschland (u-m-o), Holland, Belgien (Boldérien, Anversien), Westfrankreich (Burdigalien, Helvétien, Tortonien).

Pliocän: England, Belgien, Italien.

\section{Dentalium (Entalis) badense Parts ch}

Zu dieser Form werden drei Schalenbruchstücke gerechnet.

$\begin{array}{lccl} & \text { I } & \text { II } & \text { III } \\ \text { Durchmesser: } & 4,7 & 4,3 & 3,4 \mathrm{~mm} \\ \text { Anzahl der Rippen: } & 13 & 14 & 14\end{array}$

Das charakteristische für dieses Dentalium im Vergleich zu anderen nahestehenden Formen wie D. mutabile Dönerlein und D. Dollfusi v. Koen. ist, dass die Rippen, deren Anzahl beträchtlich variieren kann, und die dazwischen liegenden Zwischenräume mit einer aus feinen Längstreifen bestehenden Skulptur versehen sind. Diese werden wieder von den Zuwachsstreifen gekreuzt, sodass an gewissen Teilen der Schale ein feines Netzwerk entsteht.

KaUtsky versucht eine Varität borealis aufzustellen. Sie soll sich durch 1. die Grösse, 2. durch den grösseren Durchmesser an der Basis, und 3. durch breitere, flachere Rippen von den Formen des Wienerbeckens unterscheiden. Da man aber aus der Literatur ersieht, dass auch die Wiener Exemplare in dieser Beziehung variieren, muss die Aufstellung einer neuen Varietät auf Grund dieser Merkmale als ziemlich unbegründet angesehen werden.

Mi ocän: Dänemark, Norddeutschland (u-m-o), Belgien (Anversien) Westfrankreich (Tortonien), Wiener Becken (2 Medit.), Italien (Aquitanien, Burdigalien, Helvétien).

Pliocän: Italien. 


\section{Gastropoda.}

\section{A. Prosobranchia.}

\section{Xenophora Deshayesii Mich.}

(Tafel V, Fig. 1, 2).

Von dieser Art ist nur ein Gehäuse gefunden, Höhe $24 \mathrm{~mm}$, Breite 26,5 mm. Das Embryonalende und die Schlusswindung sind ein wenig zerbrochen.

Die Fremdkörper, die an der Schale festhafteten, waren hauptsächlich Schalen des Cardium subturgidum.

Die Basis der Schlusswindung trägt auf der inneren Hälfte in der Nähe des Nabels 4 flache Spiralstreifen, die äussere Hälfte dagegen nur Zuwachsstreifen. Hierdurch schliesst diese Form sich nach Roth v. Telegd an den älteren südlichen Formenkreis an, da die jüngeren Formen Spiralstreifen auf der ganzen Oberfläche der Basis tragen.

Oligocän: Italien (Tongrien).

Miocän: Dänemark, Norddeutschland (u-m-o?), Holland, Belgien (Boldérien, Anversien), Westfrankreich (Burdigalien), Wiener Becken (Grund. Sch., 2 Medit.), Italien (Helvétien).

Pliocän: Italien.

\section{Solarium Dumontii $\mathrm{N}$ y st}

(Tafel V, Fig. 3, 4, 5).

2 Exemplare, das grösste hat eine Höhe von $4 \mathrm{~mm}$, Breite $18,7 \mathrm{~mm}$ und besteht aus $4 \frac{1}{2}$ Umgängen.

Das Embryonalende besteht aus $1 \frac{1}{2}$ Umgängen, es ist ein wenig abgerieben, weshalb die Skulptur nicht erkennbar ist; nach Nyst ist das Embryonalende glatt. Die folgenden Umgänge haben dasselbe Aussehen wie die Schlusswindung. Diese trägt auf der nach oben gewendeten Seite etwa 50 leicht zurückgebogene Rippen. Auf der Aussenseite findet man drei kräftige Spiralstreifen von tiefen Furchen getrennt. Da die Rippen der Oberseite sich auf den Spiralen fortsetzen, bekommen diese ein perlschnurartiges Aussehen. Die Mittelspirale ist am kräftigsten, die untere am schwächsten.

Die Unterseite der Windung wird durch 2 Spiralfurchen in drei charakteristische Abschnitte geteilt. Der dem Nabel am nächsten liegende Abschnitt nimmt $1 / 5$. der Unterseite ein und ist mit 20 relativ kräftigen Querrippen verziert. Der innerste Rand der Unterseite wölbt sich ein wenig über den Umbilicus. Der mittlere spiralförmige Abschnitt nimmt $2 / 5$ der Unterseite ein und ist mit der doppelten Anzahl Querrippen versehen. Diese sind schwächer als die des Innerabschnittes. Der äussere Abschnitt nimmt den Rest der Unterseite ein. Nach innen, an der Grenze zu dem besprochenen mittleren Teil, findet man Knoten derselben Grössenordnung wie die der Rippen im mittleren Teil, aber in ungefähr der doppelten Anzahl oder ein bischen weniger. Nach aussen teilt sich jeder Knoten in 2-4 feine niedrige Streifen, die sich an den untersten der Spiralstreifen der Aussenseite anschliessen; sie werden von $4-5$ unter der Lupe erkennbaren, sehr feinen Spiralfurchen gekreuzt.

Die Sutur wird in der Furche zwischen der mittleren und obersten Spirale der Aussenseite angelegt.

Obgleich die Mündung nicht völlig ganz ist, kann sie mit Hilfe der Zuwachsstreifen wie folgt charakterisiert werden. Indem der Mundrand an der Oberseite der Schale den Rippen folgt, biegt er ein wenig zurück und setzt auch hiermit an der Aussenseite der Windung fort. Unten dagegen springt 
der Rand nur soweit vor, dass er sich beim Abschluss hinter dem oberen Anfang befindet.

An dem Nabel bildet die Mündung ungefähr einen rechten Winkel mit einem sehr kurzen Kanal an der Winkelspitze. Der dem Nabel zugewandte Teil des Randes ist ein wenig konkav.

Der Durchmesser des Nabels ist ungefähr gleich der Breite der Schlusswindung.

Die Exemplare stimmen gut mit Nyst's und v. Koenen's Beschreibungen überein, sind aber nicht so steil wie das bei Nyst abgebildete Gehäuse. Dieses Merkmal variiert aber nach Nyst bei der belgischen Form.

Oligocän: Norddeutschland (m-o), Belgien (o).

Miocän: Norddeutschland (u).

Pli ocän: England.

\section{Natica (Lunatia) helicina Brocch $\mathbf{i}$}

(Tafel V, Fig. 6).

16 Exemplare, die gut zu Ravs's Beschreibung und Abbildung passen.

Diese Form ähnelt, wie von früheren Autoren erwähnt, der N. Nysti D’OrBIGNY aus dem Oligocän. Schalen mit Operculum sind nicht gefunden.

Da die miocänen Formen in der Literatur unter $N$. helicina beschrieben sind, werden die Formen vom Klintinghoved unter demselben Namen angeführt, obgleich SAcco (VIII, p. 68) sie für eine Varietät der N. catena DA Costa hält, die er var. cyclostomoides nennt.

Nach Kautsky findet man N. catena DA Costa im:

Miocän: Dänemark, Norddeutschland (u-m-o), Holland, Belgien (Boldérien, Anversien), Westfrankreich (Helvétien, Tortonien), Wiener Becken (Grunder Sch. 2 Medit.), Italien (Helvétien, Tortonien).

Pliocän: Alle europäische Ablagerungen.

Recent: Ganz Europa mit Ausnahme der Polarregion.

\section{Natica (Polinices) submammiliaris d'0 $\mathrm{rb}$ ig n y}

Nur ein Exemplar mit beschädigtem Mundrand.

Es stimmt vollständig mit KauTsky's Abbildung überein. Nach diesem Verfasser unterscheidet die N. submammillaris sich von N. Josephinia Risso u. a. dadurch, dass der Umbilicus mehr offen ist.

Wie von Ravn und Kautsky erwähnt, steht diese Form der oligocänen N. hantoniensis Pilk. sehr nahe.

Miocän: Dänemark (m-o), Norddeutschland (u-m), Holland, Belgien (Anversien), Wiener Becken (Grunder Sch.), Italien (Helvétien, Tortonien).

\section{Pyramidella plicosa B r on n}

Nur ein Exemplar mit folgenden Dimensionen: Breite 1,7 mm, Höhe 3,8 mm; die Schale besteht aus sechs Umgängen.

Diese Form ist mit der P. conulus Speyer verwandt, ja vielleicht auch damit identisch, da die Merkmale, die für die Trennung der beiden Formen angeführt werden, in so hohem Grade zu variieren scheinen, dass eine Trennung sehr schwierig wird (SPEyer, Cassel p. 183, t. 25, f. 1).

Miocän: Dänemark (m-o), Norddeutschland (u-m-o), Belgien, (Anversien), Westfrankreich (Burdigalien, Helvétien,Tortonien), Wiener Becken (2 Medit.), Ober Schlesien, Italien (Helvétien, Tortonien), Ungarn (Tortonien).

Pliocän: Alle europäische Ablagerungen. 


\section{Eulima subula d'0 r b ig n y}

Nur ein Gehäuse mit leicht beschädigtem Mundrand liegt vor, Höhe 3,75 mm, Breite 1,05 mm. Ausserdem auch ein Bruchstück einer grösseren Schale.

Das Exemplar passt gut zu der von Speyer gegebenen Abbildung. Die Umgänge sind nicht konvex, weshalb die Schale ein spitz- kegelförmiges Aussehen hat. Die ersten Umgänge sind jedoch schwach konvex. Die Oberfläche ist völlig glatt und glänzend.

Wie Gripp unterstreicht, unterscheidet sich diese Form von E. flexuosa v. Koen. durch die weniger schräg verlaufende Sutur und die geraden, schräg nach links verlaufenden Zuwachsstreifen.

Oligocän: Kassel (o).

Miocän: Norddeutschland (u).

\section{Turritella Geinitzi S peyer}

(Tafel V, Fig. 7, 8, 9).

Eine grosse Anzahl Schalenbruchstücke sind gefunden, jedoch keines mit Embryonalende oder mit unversehrter Mündung.

Wievon Speyer, v. Koenen und Gripp erwähnt, ändert dieSpiralskulptur sich mit dem Wachstum der Schale. Nach Gripp ist das Embryonalende völlig glatt.

Die jüngsten Teile der Schale tragen oft eine grössere Anzahl gleich kräftiger Spiralen, die älteren Mittelwindungen oft drei kräftigere mit dazwischenliegenden feineren. Die ältesten Teile der Mittelwindungen aber tragen anfangs nur eine kräftige Spirale.

Das Profil der Umgänge verändert sich von den ältesten zu den jüngsten Teilen in folgender Weise: konvex gekielt mit kräftiger Mittelspirale; danach wird der Umgang flacher, um zuletzt nahe der oberen Naht schwach konkav und nahe der unteren schwach konvex oder flach zu sein.

Die Skulptur der Schale ist dieselbe wie bei Speyer's t. XX, f. 9-10.

Roth v. Telegd führt mit Vorbehalt Schalen aus Ungarn unter T. Sandbergeri MAYER auf. Die gewissenhafte Beschreibung zeigt vollständige Übereinstimmung mit den Exemplaren vom Klintinghoved.

Oligocän: Norddeutschland (m-o), Mitteldeutschland (o).

Miocän: Norddeutschland (u), Ungarn (Aquitanien), Siebenbürgen (Aquitanien).

\section{Bittium convexorude S a ceo}

(Tafel V, Fig. 10).

Diese kleinen Gehäuse sind ziemlich zahlreich, etwa 40 Exemplare sind gesammelt.

Cossmann und Peyrot, die eingehend die aquitanischen Bittium Spezies untersuchten, stellen die von SAcco als B. spina var. convexorudis beschriebene Form als selbständige Art auf.

Das Embryonalende besteht aus etwa 3 glatten Umgängen. Die Mittelwindungen tragen anfangs zwei Spiralstreifen; zwischen diesen und der oberen Naht schiebt sich schnell erst eine und dann eine zweite Spirale ein, so dass die Umgänge ungefähr von der vierten Mittelwindung an 4 Spiralstreifen tragen. Die Streifen sind inaequidistant. Geben wir den Spiralen von der oberen Naht nach unten die Nummern 1, 2, 3 und 4, so ist der Abstand 1-2 kleiner als $2-3$ und dieser wieder kleiner als 3-4.

Die Spiralstreifen werden von Längsrippen überquert, der Abstand zwi- 
schen diesen ist kleiner als zwischen den Spiralen 3-4. Die Kreuzungspunkte werden durch Dörnchen markiert.

Auf den jüngsten Teilen schieben sich zwischen den primären Spiralen feinere Spiralstreifen ein.

Die Mündung ist rund und trägt einen kleinen spitzen Kanal. Auf der Unterseite der Schlusswindung findet man längs der Aussenkante zwei glatte Spiralen.

Soweit man nach Hoernes' Abbildung der B. spina urteilen kann, herrscht auch ziemliche Übereinstimmung zwischen dieser Form und den Exemplaren vom Klintinghoved. Diese Vermutung kann aber nicht durch Vergleichs material bestätigt werden.

Unter den aus dem Nordseebecken unter B. spina beschriebenen Schalen wird man sicher solche finden, die zu B. convexorude SAcco gehören.

Miocän: ?Norddeutschland (u-m) ?Holland, ?Belgien (Anversien), Westfrankreich (Tortonien), Ungarn (Aquitanien), Italien (Helvétien).

\section{Newtoniella (Seila) cyrtogyra Cossm. et Peyrot}

(Tafel V, Fig. 11).

Nur die letzten $2 \frac{1}{2}$ Umgänge einer sonst wohlerhaltenen Schale liegen vor. Durchmesser der Schale an der Schlusswindung 1,7 mm; die ursprüngliche Länge war etwa $6,5 \mathrm{~mm}$.

Die Mündung ist oval mit kurzem spitzen Kanal, der nach links gedreht ist. Der letzte Umgang wird durch einen untersten glatten Spiralstreifen in einen basalen und einen lateralen Teil geteilt.

Der basale Teil bildet mit der Columella einen annähernd rechten Winkel. Die Oberfläche dieses Teiles ist glatt, unter der Lupe bemerkt man feine sichelförmige Zuwachsstreifen.

Der laterale Teil der Schlusswindung trägt über der besprochenen glatten Spirale drei mit dieser und unter sich aequidistanten Spiralen, die perlschnurartig geformt sind, indem sie, wo sie von den Längsrippen gekreuzt werden, anschwellen. Jeder Umgang trägt etwa 40 Längsrippen. Die oberste Spirale liegt dicht an der oberen Naht, zwischen dieser und der Spirale liegen zwei sehr feine Spiralstreifen.

Die Naht wird unmittelbar an die glatte Spirale angelegt. Die Umgänge sind schwach konvex.

Von der N. (Seila) trilineata PHiL. unterscheidet sich diese Form durch die Konvexität der Umgänge und die Perlschnurform der drei obersten Spiralen. Das von Ravn unter Cerithium Genei Мıсн. beschriebene Stück scheint nach der Beschreibung auch hierher zu gehören ${ }^{1}$ ).

Miocän: Dänemark (?), Westfrankreich (Aquitanien).

\section{Chenopus speciosus S chlotheim var. Margerini de Konin ck}

(Tafel V, Fig. 12).

Schalen dieser Art sind sehr häufig. Etwa 20 mehr oder weniger defekte Schalen sind gesammelt. Sie stimmen gut mit den von Beyrich, Speyer, RAVN und GrIPP gegebenen Abbildungen und Beschreibungen überein.

Anscheinend ohne die Arbeit Roth v. Telegd's zu kennen, meint Kautsky feststellen zu können, dass C. speciosus auf das Nordseebecken beschränkt sei.

1) Ravn's Originalexemplar, das im Mineralogischen Museum zu København aufbewahrt wird, ist von der Säureverwitterung derart zersetzt, dass Einzelheiten nicht beobachtet werden konnten. 
Die genannte Arbeit zeigt aber, dass man diese Form auch innerhalb der mediterranen Gegenden findet.

Oligocän: Dänemark (m-o), Norddeutschland (u-m-o).

Mi ocän: Dänemark (m-o), Norddeutschland (u-m), Ungarn (Aquitanien).

\section{Cypraea (Zonaria) amygdalum B r o c ch i}

(Tafel V, Fig. 13).

Nur eine ein wenig defekte Schale.

Dieses Exemplar stimmt mit den Abbildungen bei Hoernes u. Autnger und Kautsky überein. Höhe $33,5 \mathrm{~mm}$, Breite $24 \mathrm{~mm}$.

Miocän: Norddeutschland (m), Holland, ?Belgien (Anversien), Westfrankreich (Burdigalien, Tortonien), Wiener Becken (Grunder Sch. 2 Medit.) und Italien (Helvétien).

\section{Pyrula simplex B e y r.}

(Tafel V, Fig. 14).

3 Exemplare und 3 Bruchstücke. Das grösste Exemplar misst: Höhe 32,7 $\mathrm{mm}$, Breite 24,2 $\mathrm{mm}$.

Die Schalen stimmen mit BEyrich's Beschreibung und Abbildungen überein, weshalb ich hierauf verweise.

Kautsky erwähnt die Verwandtschaft dieser Form mit der P. Harrisi Mart. aus Maryland (Maryland Miocene, p. 226, t. 50, f. 3). Diese letzte unterscheidet sich aber durch flacheres Gewinde. Da sie vielleicht in dieser Hinsicht variieren kann, ist es möglich, dass die beiden Formen identisch sind.

Oligocän: Norddeutschland (o).

Miocän: Norddeutschland (u-m), Belgien (Anversien).

\section{Cassidea (Semicassis) Rondeletii B a s t e r o t}

(Tafel V, Fig. 15).

3 wohlerhaltene Schalen liegen vor, dem abgebildeten grössten Exemplar, welches $58 \mathrm{~mm}$ hoch und $32 \mathrm{~mm}$ breit ist, fehlt aber der Kanal.

Die Schalen stimmen gut mit BEYRIch's Beschreibung überein.

Olig o cän : Dänemark (m-o), Norddeutschland (m-o), Italien (Tongrien).

Miocän: Dänemark (m-o), Norddeutschland (u-m-o), Belgien (Anversien), Westfrankreich (Burdigalien), Italien (Helvétien).

\section{Tritonium (Simpulum) enode B e y r.}

(Tafel V, Fig. 16).

15 Exemplare und ausserdem eine Jugendform, die aus der Embryonalschale und einem halben Umgang besteht, liegen vor.

Von dieser Art, die sich im Schalenbau sehr dem Tritonium flandricum De Koninck nähert, hat Gripp (36) eine ausführliche Beschreibung geliefert, worauf ich verweise.

Oligocän: Norddeutschland (o).

Miocän: Norddeutschland (u).

\section{Murex (Haustellum) paucispinatus R oth $\mathrm{v}$. Tele gd}

(Tafel V, Fig. 17).

2 Exemplare, wovon das eine völlig erhalten ist. Länge $48,4 \mathrm{~mm}$, Breite $23,7 \mathrm{~mm}$.

Wie von Roth v. Telegd erwähnt, nimmt diese Form eine Mittelstellung zwischen M. Partschi Hoernes und M. spinicosta Bronn ein.

M. paucispinatus unterscheidet sich von $M$. Partschi durch das Fehlen der 
langen Dornen der Varices, nur ein schwacher Dorn findet sich oben an jedem Varex, obgleich der Dorn auch gänzlich fehlen kann. Auf der Vorderseite dieses Dorns findet man oft einen Schlitz, der zum Mundrand führt. Auf den jüngsten Teilen der grösseren Schalen verkümmert der Dorn. Die Schlusswindung trägt 5 Varices, die ersten Mittelwindungen dagegen nur 3. Im übrigen herrscht gute Übereinstimmung mit den Beschreibungen Rотн v. TELEgD's und Kautsky's.

Kautsky stellt die hierher gerechneten Schalen aus Hemmoor als Varietät zu Murex inornatus Beyr., indem dieser Verfasser angibt, dass sich Übergangsformen zu dieser Art vorfinden. Dass eine Abgrenzung der Formen dieser Gruppe etwas schwierig ist zeigt die Literatur.

Die Form aus Ungarn weicht durch etwas längere Dornen von den Klintinghoved-Formen ab.

Miocän: Norddeutschland (u?-m), Ungarn (Aquitanien).

\section{Murex (Muricantha) Deshayesii Nyst}

(Tafel VI, Fig. 1).

3 Exemplare, wovon das grösste recht gut erhalten ist; das Embryonalende ist jedoch abgerieben und auch die Mündung ist beschädigt.

Die Schalen stimmen gut mit Gripp's Abbildung überein, sind aber schlanker als die von Roth v. Telegd abgebildete Schale.

Oligocän: Dänemark (m-o), Norddeutschland (u-m-o), Belgien.

Miocän: Dänemark, Norddeutschland (u), Wiener Becken (1 Medit.) Ungarn (Aquitanien).

\section{Tiphys horridus Brocch i}

(Tafel VI, Fig. 2, 3).

Von dieser Art sind nur 2 Schalenbruchstücke gefunden, nämlich eine Schlusswindung mit erhaltenem Mundrand und ein kleineres Bruchstück.

Auf die Unterschiede zwischen dieser Form und T.pungens haben schon die früheren Verfasser aufmerksam gemacht.

Miocän: Dänemark (m-o), Norddeutschland (u-m-o), Holland, Belgien (Anversien), Westfrankreich (Burdigalien, Helvétien, Tortonien), Wiener Becken (2 Medit.), Ungarn (Aquitanien) und Italien (Helvétien, Tortonien).

Pliocän: Italien.

\section{Atilia (Macrurella) subulata Brocchi}

(Tafel VI, Fig. 4, 5).

5 Exemplare. Höhe $6 \mathrm{~mm}$, Breite 2,5 mm.

Das Embryonalgewinde ist glatt und besteht aus 3 gewölbten Umgängen.

Die ersten Mittelwindungen sind anfangs mit breiten flachen Längsrippen versehen, sie verschwinden aber auf den jüngsten Teilen der Schale, die glatt sind. Die Windungen sind hier verhältnismässig flach und mit feinen $\mathrm{Zu}-$ wachsstreifen und undeutlichen feinen Spiralfurchen versehen.

Die Mündung ist rhombenförmig abgerundet und mit kurzem Kanal versehen. Auf der Aussenlippe findet man auf der einen Schale sechs flache Zähnchen. Die Aussenseite des Kanals trägt etwa 8 verhältnismässig grobe Spiralrippen.

Durch die rhombenförmige Mündung unterscheidet diese Form sich u. a. von der A. attenuata BEYr.

Miocän: Norddeutschland (m), Holland, Westfrankreich (Helvétien), Wiener Becken (Grunder Sch. 2 Medit.)

Pliocän: England, Holland, Belgien und Italien. 
42. Nassa (Telasco) Schlotheimi B e yr.

(Tafel VI, Fig. 6).

10 Exemplare, die gut mit den Beschreibungen Ravn's, Harder's und Gripp's übereinstimmen. Die Schalen vom Klintinghoved gehören zu den gedrungenen Formen (siehe BEYrich l. c.)

Die von Kautsky aufgestellte N. Schroederi stimmt in den meisten Merkmalen mit N. Schlotheimi überein. Da diese Form sehr variiert (BEyrich (6) Gripp (36)), ist es fraglich, ob jene nicht nur eine Varietät dieser ist.

Peyrot's Beschreibung der N. Neuvillei und die Abbildungen von dieser Form zeigen, dass ihm N. Schlotheimi vorlag.

Oligocän: Dänemark (o), Norddeutschland (o).

Miocän: Dänemark, Norddeutschland (u-m?), Westfrankreich (Tortonien.)

\section{Dolicholathyrus (Pseudolathyrus) Rothi B eyr.}

$$
\text { (Tafel VI, Fig. 7). }
$$

Zwei Exemplare und zwei Schalenbruchstücke. Das Embryonalende ist bei keinem der Stücke erhalten.

Mit Hoernes und Auinger unterscheidet Kautsky diese Form von dem pliocänen F.crispus Borson, zu welcher Art Gripp diesbezügliche Formen vom Klintinghoved gerechnet hat.

Diese Form zeichnet sich durch eine charakteristische Skulptur aus. Sie besteht aus 7-10 kräftigen Längsrippen pro Umgang'1), die von markierten dünnen Spiralstreifen überquert werden. Von diesen findet man auf den Mittelwindungen 3-4 kräftigere erster Ordnung, zwischen ihnen schiebt sich in jedem Zwischenraum ein solcher zweiter Ordnung ein, und in den so entstandenen neuen $Z$ wischenräumen kommt als letztes Glied je eine noch feinere Spirale 3. Ordnung. Zwischen der der oberen Naht am nächsten liegenden Spirale 1. Ordnung und der Naht liegen 3-4 oder mehr feinere Spiralstreifen etwa 2. Ordnung.

Die Mündung ist eiförmig; auf der Aussenlippe findet man etwa 10 flache Zähnchen. Die Innenlippe trägt oben eine knotenförmige Verdickung, am Anfang des Kanals zwei Streifen, die sich auf der Columella fortzusetzen scheinen.

Mi o cän : Dänemark, Norddeutschland (u-m-o), Holland, Belgien(Anversien), Ober Schlesien, Wiener Becken (2 Medit.) und Italien (Tortonien).

\section{Streptochetus sexcostatus Bey rich}

Nur ein Exemplar. Das Embryonalende fehlt, der Kanal und die Mündung sind ein wenig zerbrochen.

Die fehlenden Teile erschweren eine genaue Bestimmung, da S. sexcostatus und Aquilofusus Waeli Nyst, wie von Gripp (1915) erwähnt, durch den Bau der Embryonalschale unterschieden werden.

Der Kanal des Exemplares ist deutlich nach links gebogen, ausserdem trägt die Schale nur 8-9 Längsrippen auf jedem Umgang. Da A. Waeli 12-16 Rippen pro Umgang trägt, und da der Kanal bei dieser Form entweder gerade oder nach rechts gedreht ist, dürfte hier also wirklich S. sexcostatus vorliegen.

Die Mittelwindungen tragen übereinstimmend mit BEyrich's Beschreibung 5 kräftigere Spiralen, zwischen denen sich feinere einschieben.

Miocän: Dänemark (m), Norddeutschland (11-m), Holland, Belgien (Anversien).

1) Auf dem einen Bruchstück, das einem unnormal ausgebildeten Exemplar angehört hat, steigt die Anzahl der Rippen bis auf 13. 


\section{Aquilofusus pereger B e y i ch}

(Tafel VI, Fig. 8).

3 ein wenig zerbrochene Exemplare ohne Embryonalende sowie zwei Schalenbruchstücke liegen vor.

Gripp führt diese Art als Leitfossil der Vierländer Stufe an.

Miocän: Dänemark, Norddeutschland (u).

\section{Sveltia varicosa $\mathrm{B} \mathrm{roch}$}

(Tafel VI, Fig. 9).

3 wohlerhaltene Exemplare und ein Bruchstück.

Die Embryonalschale besteht aus drei glatten Umgängen.

Die Mittelwindungen tragen ein wenig über der Mitte eine besonders kräftige Spirale, die, wo die Längsrippen geschnitten werden, eine kleine Spitze bildet.

Die Mündung ist birnenförmig. Auf der Aussenlippe schmale Streifen. Die Columella trägt zwei Falten. Der Nabel ist klein und oft von der Innenlippe bedeckt.

Die Exemplare stimmen gut mit Kautsky's Abbildung überein. Mit HarDER's Figur verglichen ist die Form weniger schlank, und die Umgänge tragen mehr Längsrippen als diese.

Miocän: Norddeutschland (u-m), Holland, Belgien (Anversien), Westfrankreich (var. paucicostata u. var. bearnensis: Helvétien; var. simplicior: Tortonien), Wiener Becken (2 Medit.) und Italien (Helvétien).

Pliocän: Mittelmeer und England.

\section{Conus (Leptoconus) Allionii M i che lot t i}

(Tafel VI, Fig. 10, 11).

18 Exemplare und mehrere Bruchstücke. Das grösste ist etwa $30 \mathrm{~mm}$ hoch und $16 \mathrm{~mm}$ breit.

Nach Gripp besteht das Embryonalende aus $5 \frac{1}{2}$ glatten Umgängen. Auf den ersten Mittelwindungen ist der Kiel mit Höckerchen versehen, die alsbald schwächer werden. Das Dach der Mittelwindungen trägt oft sehr feine Spiralstreifen. Das Gewinde variiert sehr, es kann hoch und niedrig sein. Das eine der abgebildeten Stücke hat ein niedriges Gewinde, welches von der Embryonalschale überragt wird, das andere ein höheres. Die treppenförmige Ausbildung der Schale wird an einigen Stücken dadurch verwischt, dass der Kiel gerundet ist.

C. Allionii trägt auf dem unteren Teil der Schlusswindung zu oberst sehr feine Spiralen, zu unterst kräftigere Spiralfurchen, sonst ist die Schale glatt und glänzend.

Conus Semperi Speyer unterscheidet sich nach Speyer (Cassel p. 4, t. 1, f. 1-5) durch ein Embryonalende von 4 Umgängen und eine auf der Schlusswindung stärker entwickelte Spiralskulptur.

Miocän: Dänemark, Norddeutschland (u-m), Belgien (Anversien) und Italien (Helvétien).

\section{Genotia trochlearis $\mathrm{H}$ o e r nes}

(Tafel VI, Fig. 12).

Von dieser seltenen Art sind 5 teilweise wohlerhaltene Stücke gefunden.

Das Embryonalende besteht aus 3 glatten gewölbten Umgängen.

Die Carina der Mittelwindungen, die ein wenig gerundet erscheint, trägt wie die Seitenwand der Windungen deutliche Spiralfurchen. Über der Carina bemerkt man nur die Zuwachsstreifen, die von dieser gegen die Naht 
weit zurückgreifen. Zwischen den Stücken befinden sich gedrungene und schlankere Formen, da die Naht entweder dicht an der Carina oder weiter unten angelegt werden kann. Die Carina kann auf den ersten Mittelwindungen kleine Höckerchen tragen.

Die von SAcco abgebildete Schale ist noch mehr gedrungen als die Exemplare vom Klintinghoved.

Die seltene Form ist nur aus Schlesien, dem Wiener Becken, Siebenbürgen und Italien bekannt.

Miocän: Ober Schlesien, Wiener Becken (2 Medit.), Siebenbürgen und Italien (Helvétien).

\section{Surcula Steinvorthi S e m per}

(Tafel VI, Fig. 13).

18 Exemplare.

Das Embryonalende besteht wie auf HArder's fig. $6-7$ aus 4 glatten Umgängen.

Die Mittelwindungen tragen im Gegensatz zu S. regularis keine Längsfalten, ausnahmsweise können solche auf den ersten Mittelwindungen sehr schwach entwickelt sein. In diesen Merkmalen stimmen die oligocänen Formen Harder's sehr gut mit den Formen vom Klintinghoved überein. Überhaupt lässt sich schwer eine Trennung jener Formen von diesen vornehmen, weshalb ich die im Oberoligocän von Aarhus vorkommenden Formen zu S. Steinvorthi stelle.

Oligocän: Dänemark (o).

Miocän: Dänemark (m), Norddeutschland (u-m-o), Holland, Belgien (Bolderien, Anversien), Ungarn (Aquitanien).

\section{Pleurotoma rotata B r o c chi}

9 Exemplare.

(Tafel VI, Fig. 14).

Das Embryonalende besteht aus 2 glatten und $2-3$ berippten Umgängen; diese letzten tragen etwa 15 Längsrippen pro Umgang; sonst sind die Windungen glatt.

Die Carina liegt auf der Mitte der Mittelwindungen und ist mit einer doppelten Knotenreihe versehen, deren Knoten zwei Spiralstreifen verbinden.

Die Schlusswindung trägt unter der Carina drei kräftige Spiralstreifen, zwischen welche sich noch feinere einschieben. Von den Spiralstreifen über dem Kiel ist die oberste am kräftigsten.

Die Naht wird an der mittleren der erwähnten drei kräftigen subcarinalen Spiralen angelegt, ausnahmsweise zwischen dieser und der unteren.

Der Sinus der Mündung liegt auf der Carina. Die Schlusswindung fällt recht steil zum Kanal ab.

Die aus Ungarn erwähnte Schale muss ich zu P. rotata stellen, da sie nach der Beschreibung hiermit übereinstimmt.

Miocän: Westfrankreich (Aquitanien?, Tortonien), Ober Schlesien, Wiener Becken (2 Medit.), Italien (Helvétien, Tortonien), Ungarn (Aquitanien).

Pliocän: Italien.

\section{Pleurotoma trifasciata $\mathrm{Ho}$ e rnes}

6 Schalenbruchstücke.

Diese Form unterscheidet sich von der $P$. rotata durch die drei Spiralrippen der Carina und durch die schwächere Entwicklung der Knoten der Carina. 
Von der P. Geinitzi unterscheidet sie sich u. a. durch steileres Abfallen der Schlusswindung.

Oligocän: Norddeutschland (o).

Miocæn: Norddeutschland (u-m), Holland, Wiener Becken (2 Medit.), Ober Schlesien und Italien (Helvétien).

\section{Pleurotoma (Hemipleurotoma) Duchastelii $\mathrm{N}$ y s t}

(Tafel VI, Fig. 15).

7 Exemplare.

Das Embryonalende besteht aus 3 glatten Umgängen und 11/4 Umgänge sind mit glatten Längsrippen versehen.

Die Exemplare vom Klintinghoved nehmen eine Mittelstellung zwischen SPeyer's var. vera und var. multilineata ein.

Oligocän: Dänemark (m-o), Norddeutschland (m-o).

Miocän: Dänemark, Norddeutschland (u-m-o), Belgien (Boldérien, Anversien), Holland, Ungarn (Aquitanien).

\section{Bathytoma cataphracta Brocch i}

8 Exemplare.

(Tafel VI, Fig. 16).

Das Embryonalende besteht im Ganzen aus 3 Windungen, die 3/4 des letzten Umganges sind mit glatten Längsrippen verziert, sonst ist das Embryonalende völlig glatt.

Der Gewindewinkel des Gehäuses variiert mit der Anhaftungsstelle des letzten Umganges: die Naht kann in verschiedenem Abstand von der Carina angelegt werden, liegt sie dicht an der Carina, so liegen gedrungene Formen vor, und wird sie weiter unten angelegt, so sind die Formen schlanker.

Die Skulptur variiert ziemlich; ich verweise in dieser Beziehung auf die zitierte Literatur.

Es ist fraglich, ob man nicht mit GRIPP und anderen Verfassern den B. cataphracta-Formenkreis dem B. turbida-Formenkreis anreihen sollte. KAUTSKY bemüht sich eine Trennung beizubehalten, obgleich die Frage noch nicht als gelöst gelten kann.

Oligocän: Dänemark (m-o), Norddeutschland (o).

Miocän: Dänemark (m-o), Norddeutschland (u-m-o), Holland, Belgien (Boldérien, Anversien), Westfrankreich (Aquitanien, Burdigalien, Helvétien, Tortonien), Ober Schlesien, Wiener Becken (Grunder Sch. 2 Medit.), Italien (Helvétien, Tortonien).

\section{Drillia (Cymatosyrinx) Selenkae v. K o e n.}

(Tafel VI, Fig. 17).

2 Exemplare mit abgeriebenem Embryonalende und beschädigtem Mundrand.

Die Schalen entsprechen den Beschreibungen und Abbildungen von v. KoENEN und KAUTSKY, sind aber wohl ein wenig schlanker.

Kautsky bemerkt, dass Beziehungen zu der Drillia limatula Conrad var. pyramidalis Martin aus Maryland (Maryland Miocene, p. 169, t. XLII, fig. 16) bestehen. U. a. ist die $D$. Selenkae aber bedeutend schlanker, sodass wenigstens nicht von derselben Art die Rede sein kann.

Miocän: Norddeutschland (u-m), Holland, Westfrankreich (Tortonien), Italien (Tortonien). 
55. Daphnella (Raphitoma) Roemeri Phil. sp.

(Tafel VI, Fig. 18).

Ein Exemplar mit beschädigtem Mundrand und ein grösseres Schalenbruchstück liegen vor. Höhe: $10,4 \mathrm{~mm}$, Breite: 4,7 mm.

Es ist bemerkenswert, dass das Embryonalende, welches aus $31 / 2$ Umgängen besteht, nicht glatt ist, wie die früheren Verfasser es beschreiben, sondern es trägt eine sehr feine Netzskulptur aus diagonal gestellten Streifen, die unter Lupe beobachtet werden können. Wahrscheinlich ist es diese Skulptur, die v. Koenen aber nur auf dem letzten Umgang des Embryonalendes beobachtete und als Spiralstreifen und Längsfäden deutete.

Die Mittelwindungen werden durch die Kante in zwei Teile geteilt, von welchen der obere, der den Sinus der Zuwachsstreifen trägt, nur mit feinen Spiralstreifen verziert ist; der untere dagegen trägt ausserdem schräg gestellte Längsrippen, deren Zahl bedeutend schwankt (10-20 pro Umgang). Auf den jüngsten Windungen werden die Rippen flacher und können beinahe verschwinden.

Kautsky versuchte die oligocänen Formen von den miocänen zu trennen. Da er aber seine Trennung auf variierende Merkmale wie Längsrippen und Kante basiert, habe ich ihm hierin nicht folgen können, da mir seine Trennung zu unnatürlich erscheint.

Oligocän : Norddeutschland (m-o).

Miocän: Norddeutschland (u-m).

\section{B. Opisthobranchia.}

56. Ringicula $\mathrm{sp.}$

Nur ein Bruchstück des letzten Umganges einer Schale dieses Genus ist gefunden.

\section{Scaphander lignarius L. var. Grateloupi $\mathbf{M}$ i ch.}

(Tafel VI, Fig. 19).

2 wohlerhaltene Exemplare und zwei ein wenig defekte Stücke liegen vor.

Nr. I. Höhe: 23,7 mm, Breite: 13,4 mm, Verhältnis: 1,8:1

Nr. II. " : $23,8 \mathrm{~mm}$, " : $14,0 \mathrm{~mm}, \quad$ » $1,7: 1$

In ihrem Verhältnis Höhe: Breite stimmen sie gut mit den Schalen überein, die v. KoEnen beschrieb.

Miocän: Dänemark (m-o), Norddeutschland (u-m-o), Holland, Belgien, Westfrankreich (Aquitanien, Burdigalien, Helvétien), Wiener Becken (Grunder Sch. 2 Medit.), Italien (Helvétien).

\section{Bullinella cylindracea $\mathrm{P}$ e $\mathrm{n} \mathrm{n}$.}

(Tafel VI, Fig. 20).

7 Exemplare, das grösste $6,4 \mathrm{~mm}$ hoch und $3,4 \mathrm{~mm}$ breit.

Sie stimmen gut mit Ravn's und v. Koenen's Beschreibungen überein, besitzen aber keinen Nabel; was wohl mit ihrer relativen Schlankheit zusammenhängt (v. Koenen 62).

Oligocän: Norddeutschland (u-m-o).

Miocän: Dänemark (m-o), Norddeutschland (u-m-o), Holland, Belgien, Westfrankreich (Burdigalien, Helvétien, Tortonien).

Pliocän: England, Belgien, Italien.

Recent: Atlantischer Ozean (England) und das Mittelmeer. 


\section{Bullinella Seebachii v. K o e ne n}

(Tafel VI, Fig. 21).

Ein Exemplar, 6,2 $\mathrm{mm}$ hoch, 3,5 $\mathrm{mm}$ breit.

Die Schale stimmt gut mit v. KoEnen's Beschreibung und Abbildung überein.

Die Spiralfurchen liegen dicht nebeneinander oben und unten an der Schale, wo sie auch am tiefsten sind. Auf der Mitte des Gehäuses findet man etwa 10-11 Furchen auf je $1 \mathrm{~mm}$.

Der obere Nabel ist ungefähr, der untere ganz geschlossen.

Oligocän: Norddeutschland (m).

\section{Roxania utriculus B rocehi}

Nur ein wohlerhaltenes Exemplar, das 4,3 $\mathrm{mm}$ hoch und 2,8 $\mathrm{mm}$ breit ist. Stimmt mit den Beschreibungen von Speyer, Ravn und Harder überein.

Oligocän: Dänemark (o), Norddeutschland (m-o).

Miocän: Dänemark (m-o), Norddeutschland (u-m-o), Holland, Belgien (Anversien), Westfrankreich (Burdigalien, Helvétien, Tortonien) Wiener Becken (2 Medit.) und Italien (Tortonien).

Pliocän: Belgien, Italien.

Recent: Atlantischer Ozean von Norwegen bis Madeira, Mittelmeer.

\section{Actaeon Philippi K o ch sp.}

Ein ziemlich zerbrochenes Stück wird zu dieser Art gerechnet. Die Mündung ist nur teilweise erhalten, im übrigen stimmt das Stück mit SPEyer's Beschreibung überein.

Oligocän: Dänemark (o), Norddeutschland (m?-o).

Miocän: Norddeutschland (u).

\section{Pteropoda.}

\section{Spirialis stenomphalus Gripp sp.}

4 Exemplare. Die Mündung ist bei allen schlecht erhalten. Die dünne Schale ist perlmutterglänzend und glatt und besteht aus 3 bis 4 Umgängen.

Das Gewinde variiert ein wenig und ist ein bischen höher als bei dem von Gripp abgebildeten Exemplar, sodass die Schälchen sich der Spirialis dilatata v. Koenen (Unteroligocän (63) p. 994, t. LXII, f. 5-6) nähern. Der Nabel ist sehr klein. Das Exemplar, welches dem von Gripp abgebildeten Stück am nächsten kommt, ist $1,4 \mathrm{~mm}$ hoch und $0,9 \mathrm{~mm}$ breit.

Mitteloligocän der Vierlande.

2 Exemplare.

\section{Vaginella depressa $D$ a ud in}

Von der Spitze bis zu der Mitte der Schale verlaufen an jeder Seite eine Kante.

Oligocän : Dänemark (o).

Miocän: Dänemark (m-o), Norddeutschland (u-m-o), Holland, Belgien (Anversien), Westfrankreich (Aquitanien, Burdigalien, Helvétien), Ober Schlesien, Wiener Becken (2 Medit.), und Italien (Helvétien). 


\section{Crustacea.}

64. Coeloma incarinatum nov. sp.

(Tafel VII, Fig. 1-3, Tafel VIII, Fig. 1-3).

Eine Anzahl Krebsreste wurde gefunden und zwar: 3 Cephalothoraces, 1 Sternum mit Resten der Gliedmassen und mehrere Bruchstücke insbesondere von Scheren. Diese Teile konnten zu keiner der bis jetzt bekannten Arten gerechnet werden, weshalb ich sie hier unter dem Namen Coeloma incarinatum nov. sp. aufführe. Mit diesem Namen wünsche ich den Hauptunterschied zwischen dieser Form gegenüber dem von RAvN (1903) aufgestellten Coeloma bicarinatum auszudrücken (siehe Tafel VII, Fig. 4, 5 und Tafel VIII, Fig. 5, 6).

Der am besten erhaltene Cephalothorax, übrigens der einzigste weibliche, hat eine Länge von der Stirn bis zum Hinterrand von etwa $25 \mathrm{~mm}$ gehabt ${ }^{1}$ ). Der Abstand zwischen dem Epigastrallobus und der Spitze des Stirndorns derselben Seite ist etwa $3 \mathrm{~mm}$. Die Breite des Cephalothorax an den hinteren Dornen des Anterolateralrandes gemessen ist c. $31 \mathrm{~mm}$. Der Vorderrand, der von den beiden vorderen Dornen der Anterolateralränder begrenzt wird, misst $21 \mathrm{~mm}$, der Anterolateralrand $9,8 \mathrm{~mm}$ und der Posterolateralrand 13,8 mm. Die Breite des Cephalothorax an dem hinteren Abschluss des Posterolateralrandes beträgt $21 \mathrm{~mm}$.

Nahe der Mittellinie des Cephalothorax trägt die Stirn die besprochenen 2 kurzen Dornen, die $1 \mathrm{~mm}$ von einander entfernt stehen. In dem doppelten Abstand dieser trifft man an jeder Seite ein noch kleineres Dörnchen, das die Stirne an beiden Seiten begrenzt. Der Vorderrand zieht sich danach zurück und geht in den Supraorbitalrand über, der in der Mitte und dicht an dem ersten Dorn des Vorderseitenrandes mit einem kleinen Schlitz versehen ist.

Der Vorderseitenrand ist in der typischen Entwicklung mit 5 Dornen versehen; geben wir diesen Nummern von vorne nach hinten, so ist Nr. 5 am kräftigsten entwickelt, danach folgt: $1 ; 3 ; 4$ und 2. Dieser letzte kann sehr verkümmert sein, so dass man in solchen Fällen ausnahmsweise nur 4 Dornen vorfinden kann.

Der Hinterseitenrand ist gerade. Die Länge verhält sich zu der des Vorderseitenrandes etwa wie $3: 2$ oder $4: 3$.

Der Hinterrand trägt an jeder Seite eine für das letzte Schreitfusspaar bestimmte Einbuchtung, ist sonst aber gerade oder leicht convex.

Die Oberseite ist recht kräftig lobuliert. Die Epigastralloben sind kleine längliche transversal gestellte Loben, hinter ihnen liegen die beiden runden Protogastralloben, die sich seitwärts bis zu Linien parallel der Körperachse zwischen den Schlitzen der Supraorbitalränder erstrecken. Zwischen den Protogastralloben sendet der Mesogastrallobus einen langen Ausläufer vor. Der Hauptteil dieses Lobus ist etwa wie ein im Verhältnis zu der Körperachse diagonal gestellter Rhombus ausgebildet. Der lobus u rog a stricus schliesst sich diesem hinten als ein zweilappiger Lobus an. In der Furche zwischen den beiden Loben findet man unregelmässig ausgebildete Male derselben Art, die Noetling (88 I p. 151). als Haftstellen von Muskeln deutete.

Der sulcus cervicalis kann an zwei Exemplaren beobachtet werden. Er beginnt zwischen dem 3ten und 4ten Dorn des Vorderseitenrandes, und kann als S-förmiger Bogen bis zum Urogastrallobus verfolgt werden, kann danach aber nicht mehr festgestellt werden.

1) Die Stirn ist abgebrochen, konnte aber mit Hilfe eines anderen Exemplares derselben Grösse rekonstruiert werden. 
Der lobus anterobranchialis wird vorne von dem sulcus cervicalis begrenzt, hinten wird er durch eine schwache Furche von dem lobus posterobranchialis getrennt. Die exo-Region liegt vor dem fünften Dorn des Vorderseitenrandes, ist ziemlich flach und im Verhältnis zu der dahinterliegenden meso-Region eingesenkt. Diese letzte wird wieder durch eine sehr schwache Furche von der ento-Region getrennt.

Bei dem lobus posterobranchialis lassen sich die exo-meso-und ento-Regionen nicht trennen. Bemerkenswert ist es, dass man auch bei dieser Art die oft an Formen dieses Genus zu beobachtenden 2 hintereinander liegenden Höcker auf diesem Lobus vorfindet.

Der Cardiacallobus wird von dem lobus urogastricus durch eine sattelförmige Vertiefung getrennt. Jener Lobus ist mit drei Höckern versehen, zwei vorne und einem hinten. An einem der Exemplare sind die beiden vorderen durch einen Querwulst verbunden.

Der Hinterrand des Cephalothorax ist ungefähr gerade, nur unbedeutend konvex, im Gegensatz zu dem mitteloligocänen C. holsaticum Stolley, dessen Hinterrand schwach konkav ist.

Die Flanken verhalten sich wie bei C. holsaticum und C. bicarinatum, sie bilden mit dem Vorderseitenrand einen spitzen Winkel, mit dem Hinterseitenrand einen solchen von $90^{\circ}$ oder mehr.

Von den Mundteilen ist an einem der Stücke das Epistom erhalten, es stimmt vollständig mit dem des C. holsaticum überein. Das Endostom ist nicht ganz erhalten, es scheint dieselbe Entwicklung zu haben als wie bei $G$. holsaticum. Der innere Rand des Branchiostegiten hat aber eine andere Richtung als bei dieser Form, wo die Innenränder der beiden Seiten miteinander parallel sind ${ }^{1}$ ), indem diese Ränder bei C. incarinatum nov. sp. nach hinten zu konvergieren. Infolgedessen liegt der winkelrecht auf den Innenrand gerichtete Teil des Branchiostegitrandes nicht auf einer Geraden mit dem entsprechenden Teil des Randes des Branchiostegiten der entgegengesetzten Seite, wie es bei C. holsaticum der Fall ist. Die beiden Randteile bilden verlängert mit einander einen stumpfen Winkel von etwa $165^{\circ}$.

Bezüglich des C. bicarinatum scheint der Innenrand, der nur teilweise an einem der Exemplare beobachtet werden konnte, sich in derselben Weise zu verhalten wie bei C. incarinatum nov. sp. (RAvN 1903; t. V, f. 5.)

Bei C. incarinatum nov. sp. sind die Flanken grösser im Verhältnis zu den Branchiostegiten als bei C.holsaticum.

Das plastron sternale besteht aus 5 Sterniten und stimmt völlig mit dem des C. bicarinatum überein. Das männliche Abdomen ist wie bei C. bicarinatum entwickelt, das weibliche dagegen mehr gerundet als bei dieser Form, jedoch nicht so stark wie es bei dem von Stolley (118) t. V, f. 1, c. abgebildeten Exemplar von C. holsaticum der Fall ist. Die weiblichen Abdominalsegmente sind vorne konvex, hinten konkav; hierdurch schliesst sich die Form an das C. bicarinatum an, weicht aber von C. holsaticum ab, da Vorder- und Hinterrand der Segmente bei dieser Form parallel sind.

Von den Gliedmassen sind der letzte linke Kieferfuss, der linke Scherenfuss und die drei ersten Glieder des zweiten Schreitfusses erhalten. Diese Teile sind wie bei C. bicarinatum entwickelt.

Zum Abschluss sollen die trennenden Merkmale der folgenden Formen, die durch den Besitz von 5 Dornen auf dem Vorderseitenrand von den übrigen Formen des Genus Coeloma abweichen, hervorgehoben werden, nämlich:

1) Stolley (118) t. VI, f. 1a. 
Coeloma rupeliense Stainier, C. holsaticum Stolley, C. bicarinatum Ravn und C. incarinatum nov. sp.

C. bicarinatum und C. incarinatum scheinen nur in der Entwicklung der Posterobranchialloben verschieden zu sein, indem die erste Form auf diesen Loben je eine Kante trägt, die zweite jedoch keine; an der entsprechenden Stelle findet man nur 2 Höcker.

Von dem C. holsaticum unterscheidet sich C. incarinatum dadurch, dass die Dornen des Vorderseitenrandes nicht von einem „Centrum«ausstrahlen, welches im Berührungspunkt zwischen lobus protogastricus und l. anterobranchialis liegt, sondern alle 5 Dornen sind nach vorne gerichtet. Der Vorderrand bildet mit dem Vorderseitenrand einen kleineren Winkel (etwa $100^{\circ}$, C. holsaticum: $120^{\circ}$ ). Der Hinterrand ist gerade. Die Innenränder der Branchiostegiten sind nicht parallel, sondern konvergieren nach hinten zu. Das weibliche Abdomen ist mehr zugespitzt, die Segmente sind konvex-konkav.

Von C. rupeliense ${ }^{1}$ ) unterscheidet sich C. incarinatum durch die nach vorne gerichteten Dornen. Weiter ist bei C. incarinatum Dorn Nr. 2. am schwächsten, bei C. rupeliense jedoch Nr. 4. Die Stirn ist bei der letzten Form länger als bei der ersten. - Hierdurch unterscheidet sich C. rupeliense auch von C. holsaticum.

Bei C. incarinatum trägt die Stirn die äussersten Dornen gerade dort, wo die Stirn aufhört, bei C. rupeliense dagegen ist dieser Dorn der Körperachse mehr genähert, sodass er die Stirn nicht begrenzt. Bei der erstgenannten Form findet man einen geraden Hinter- und Hinterseitenrand, bei der letzten dagegen sind diese Ränder konkav bzw. konvex. Eine Fortsetzung des sulcus cervicalis auf den Flanken, die Stolley bei C. rupeliense erwähnt, findet man nicht bei C. incarinatum.

\section{Stratigraphischer Teil.}

\section{Das Alter des Klinting hoved-Glimmertones.}

In seiner klassischen Arbeit: „Über das marine Altmiocän des Nordseebeckens«, rechnet Gripp die Fauna vom Klintinghoved zum Untermiocän und zwar zu der Vierländer Stufe (Gripp 1920). Diese von Gripp vorgenommene Altersbestimmung bewährt sich auch jetzt, nachdem die neuen Aufsammlungen neues Licht über die Fauna geworfen haben.

Von den 64 Spezies waren bisher $54=84 \%$ aus untermiocänen Ablagerungen bekannt. Von den übrigen wird Nucula hanseata sich sicher zwischen den aus untermiocänen Schichten als N. laevigata Sow. bestimmten Stücken befinden ${ }^{2}$ ). Von den übrigbleibenden 9 Formen konnten 4 nicht bestimmt werden, und eine Form, der Decapode, ist neu.

Der grosse Prozentsatz darf aber nicht zu viel düpieren, da eine beträchtliche Anzahl der Formen vertikal sehr verbreitet ist. Folgende sind aber wichtig: Aquilofusus pereger Beyr., die Leitform der Vierländer Stufe; die bisher nur aus dem Aquitanien Westfrankreichs bekannte Newtoniella cyrtogyra

1) Es konnte nur mit der von Stolley gegebenen Beschreibung und Abbildung verglichen werden, da es nicht möglich war Stainier's Arbeit zu verschaffen.

${ }^{2}$ ) Als Begründung hierfür möchte ich anführen, dass Gripp vom Klintinghoved (= Sonderburg bei Gripp) N. laevigata Sow. aufgeführt hat, es hat sich aber gezeigt, dass hier die später aufgestellte $N$. hanseata Kautsky vorliegt. 
Cossm. et Peyr.; die nur aus oberoligocänen und untermiocänen Schichten bekannten Tritonium enode Beyr. und Turritella Geinitzi Speyer, und zuletzt die drei Formen: Murex paucispinatus Roth v. Telegd, Conus Allionii Mich. und Genotia trochlearis Hoennes, die alle nur als Elemente unter- oder mittelmiocäner Faunen bekannt sind.

Die Klintinghoved-Fauna ist deshalb untermiocänen Alters, die genannten sieben Formen schalten alle anderen Möglichkeiten aus.

Mit der untermiocänen Fauna der Vierländer Bohrungen, die 22 Arten zählt, hat Klintinghoved 8 Formen gemeinsam, mit der Fauna des Gripp'schen Altmiocäns dagegen 47 Formen. Beschränken wir uns bei der letztgenannten Fauna auf die auf sicher primärer Lagerstätte gefundenen Formen in den Bohrungen: Lübeck, Wismar, Blekede und Hamburg Vierlande, so ergibt sich, dass 28 Formen gemeinsam sind. Da drei der Formen ein wenig unsicher sind, bedeutet das $39 \%$ bis $43 \%$ der Klintinghovedfauna.

Dass man aber bei der Altersbestimmung nicht nur auf den Prozentsatz etwaiger gemeinsamer Formen Rücksicht nehmen darf, zeigt ein Vergleich mit der von KaUtsky beschriebenen Hemmoorer Fauna, die mit Klintinghoved 38 Formen gemeinsam hat $=59 \%$ der letztgenannten Fauna. Ausserdem trifft man in der Klintinghovedfauna Cypraea amygdalum und Murex paucispinatus, die KaUtsky als typisch für das Mittelmiocän des Nordseebeckens ansieht. Diese Formen wurden aber in untermiocänen Ablagerungen bzw. in Westfrankreich und Ungarn gefunden. Dass Klintinghoved mit Hemmoor verhältnismässig mehr Formen gemeinsam hat als mit der Fauna in den Bohrungen, liegt u. a. daran, dass die Fauna von Hemmoor mit einer grossen Anzahl von Arten so gut bekannt ist. Dass zwei Faunen verschiedenen Alters einander sehr ähnlich sein können, und dass die eine der beiden Faunen gleichzeitig einer dritten mit ihr synchronen Fauna nicht in demselben Ausmasse gleicht, bemerkt man oft, wo von einander zeitlich nahestehenden Faunen die Rede ist, und besonders wenn isopiche Faziesverhältnisse vorliegen. In solchem Fall haben die Faziesverhältnisse grösseren Einfluss auf die Fauna als der Zeitunterschied.

Auch die absolute Grösse der Faunen hat Bedeutung, wie oben erwähnt wurde. Als Beispiel soll nur nach BucQvoy (12, II, Seite 755) angeführt werden, dass die rezente norwegische Molluskenfauna mit der rezenten Mittelmeerfauna $52 \%$ ihrer Arten gemeinsam hat, die Mittelmeerfauna dagegen hat mit der norwegischen Fauna nur $25 \%$ ihrer Formen gemeinsam. Die ärmere Fauna wird also gewissermassen von der reicheren dominiert.

Nach den obigen Ausführungen ist die Klintinghovedfauna mit der Vierländer Stufe gleichaltrig. Diese Stufe parallelisierte Gripp mit dem Aquitanien, KAUtsky (49, S. 207) aber mit dem Burdigalien. Wir werden später hierauf zurückkommen.

\section{Vergleich der Fauna vom Klintinghoved mit anderen europäischen Miocän-Faunen.}

\section{Das Nordseebecken.}

In den Niederlanden kommt nach Gripp (37) kein marines Untermiocän vor, dagegen stellt dieser Verfasser die von RAvN (95) von Skyum, Skive, Viborg und Varde publizierten Faunen ins Untermiocän. 
Mit Skyum hat Klintinghoved folgende Formen gemeinsam:

?Portlandia pygmaea v. Münst.

Yoldia glaberrima v. Münst.

Astarte concentrica Goldfuss

Meretrix incrassata Sowerby

Tellina fallax Beyr.

(Panopaea sp.).

Chenopus speciosus v. Schlotн. sp.
Cassis Rondeletii Basterot

Murex (Muricantha) Deshayesii Nyst

Streptochetus sexcostatus BEYRICH

Aquilofusus pereger Beyrich

Pleurotoma (Hemipleurotoma) Duchastelii Nyst

Conus Allionii Mrchelotti

Von Skyum führt Ravn (1905) eine Fauna von 24 Formen an. Die hier angeführten Formen zeigen, dass wir es mit einer ähnlichen Fauna wie der vom Klintinghoved zu tun haben.

Das von Gripp (36) beschriebene Untermiocän von Itzehoe hat folgende Formen mit unserer Fauna gemeinsam:

Leda pygmaea v. Münst.

Yoldia glaberrima v. Münst.

Limopsis aurita BrocchI

Astarte concentrica GOLDF.

Cardium subturgidum D'OrB.

Tellina fallax BEYR.

Dentalium (Antale) vitreum Sснвöт.

Natica (Lunatia) helicina BrocchI

Eulima subula D’ORB.

Turritella Geinitzi Speyer

Chenopus speciosus var. Margerini

DE Koninck

Tritonium (Simpulum) enode BEyr.
Murex (Muricantha) Deshayesii Nyst Nassa (Telasco) Schlotheimi Beyr.

Conus (Leptoconus) Allionii Mich.

Surcula Steinvorthi SEMPER

Pleurotoma (Hemipleurotoma) Duchastelii Nyst

Bathytoma cataphracta Brocch I

Daphnella (Raphitoma) Roemeri PHIL.

Scaphander lignarius L. var. Grateloupi Мich.

Bullinella cylindracea PENN.

Roxania utriculus Brocchi

Actaeon Philippi Kocн sp.

Diese beiden Faunen dürften der Klintinghoved-Fauna nahestehen.

Eine andere Fauna, die sich mit der besprochenen vergleichen lässt, ist die Fauna gleichen Alters, die in Geschieben längs der Flensburger Förde gefunden wird (Gripp 3\%, Sorgenfrei 109). Bei einer anderen Gelegenheit hoffe ich eine eingehende Beschreibung dieser Fauna liefern zu können. GripP (37) gab in seiner Fossilienliste in der Kolumne 9 eine Zusammenstellung der damals bekannten Formen, worauf ich hinweise. Die Fauna kann jetzt beträchtlich vermehrt werden.

In der Fossilienliste auf Seite $66-67$ sind in der dritten Kolumne die mit GripP's Altmiocän gemeinsamen Formen angeführt.

\section{Ober Schlesien, das Wiener Becken und das ungarische Becken.}

1. Ober Schlesien.

Von Ober Schlesien hat Kitru (53) eine untermiocäne Fauna beschrieben. Nach Kittl ist diese Fauna eine aus oligocänen und miocänen Formen zusammengesetzte Mischfauna des untersten Miocäns. Kautsky ( 50$)$ meint, dass eine mittelmiocäne Fauna vorliegt, ohne dass jedoch eine reelle Begründung herbeigeführt wird, indem er nur auf das gemischte Gepräge der Fauna aufmerksam macht. KiтtL's Deutung ist deshalb nicht widerlegt worden, weshalb ich auf sie zurückgreife.

In Ober Schlesien und Klintinghoved kommen folgende Formen vor:

Cardium cingulatum GoLDF.

Pyramidella plicosa Bronn
Dolicholathyrus (Pseudolathyrus) Rothi Beyr. 
(Conus (Leptoconus) Allionii Мich.)

Genotia trochlearis Hoennes

Pleurotoma rotata BrocanI

Pleurotoma trifasciata Hoennes
Bathytoma cataphracta Brocchi

Roxania utriculus BrocchI

Vaginella depressa DAUdiN

Ausserdem wurden in Ober Schlesien folgende Formen gefunden, die im Klintinghoved nahestehende Verwandte vorfinden.

Leda pusio PhIL.

Cypraea cfr. Lanciae Brusina

Cytherea sp. ( $\sim$ Meretrix $)$.

Unter den genannten Formen ist besonders Genotia trochlearis wichtig, da sie sehr selten ist, indem sie sonst nur aus dem Wiener Becken, Siebenbürgen und Norditalien bekannt ist. Weiter sind für die Altersbestimmung Cardium cingulatum und Conus Allionii wichtig, da die erstgenannte Form in Ablagerungen mitteloligocänen bis untermiocänen Alters gefunden ist, während man die letztgenannte in unter- und mittelmiocänen Schichten antrifft.

Ausserdem ist es wichtig die von Kitru hervorgehobenen Beziegungen der oberschlesischen Fauna zu dem norddeutschen Oligocän festzuhalten.

\section{Das Wiener Becken.}

Nach Schaffer (102) werden die erste Mediterranstufe, die Grunder Schichten und die zweite Mediterranstufe ins Burdigalien bzw. ins Helvétien und Tortonien gestellt.

Obgleich die erste Mediterranstufe in ihrem Alter dem Horizont der Klintinghoved-Fauna näher steht als die beiden anderen Stufen, sind die faunistischen Beziehungen zu der zweiten Mediterranstufe doch grösser.

Dieser Tatsache muss u. a. durch die Faziesverhältnisse erklärt werden, da in dem Horner Becken recht spezielle Verhältnisse geherrscht haben müssen.

Mit der ersten Mediterranstufe hat Klintinghoved folgende Formen gemeinsam:

\section{Cardium (Laevicardium) cingulatum Murex (Muricantha) Deshayesii Nyst GoldF. \\ Panopaea Ménardi Deshayes Pyramidella plicosa BronN \\ Pleurotoma trifasciata Hoennes Bathytoma cataphracta Brocchi Vaginella depressa Daudin}

Die Faunenunterschiede dürfen aber nicht allein den Faziesverhältnissen zugeschrieben werden. Man darf auch annehmen, dass andere physische Faktoren, insbesondere klimatische, geographische und ausserdem ein Altersunterschied sich geltend machen. Der Altersunterschied wird aus dem folgenden hervorgehen.

\section{Das ungarische Becken.}

Die Parallelisierung mit den ältesten marinen miocänen Faunen aus Ungarn spielt eine besonders wichtige Rolle, da wir hierdurch im Stande sind, die Vierländer Stufe in das allgemeine europäische Stufensystem einzureihen.

Von den ungarischen Faunen, mit denen ein Vergleich vorgenommen werden soll, wurde die erste 1914 von Roth v. Telegd (119) veröffentlicht. Die Fauna, die bei der Stadt Eger gefunden wurde, bildet einen Übergang zwischen dem Oligocän und dem Miocän. Mit besonderer Rücksicht auf das oligocäne Element stellte Roth v. Telegd die Fauna ins obere Oligocän, das Cattien.

Bei einer Betrachtung der Fauna zeigt es sich aber, dass der oligocäne 
Anteil der Fauna aus solchen Formen zusammengesetzt ist, die man zum grössten Teil nur aus dem norddeutschen Oligocän kennt. Die übrigen Formen dagegen sind in ihrer Verbreitung typisch mediterran und ausserdem miocän. Roth v. Telegd konkludiert in folgender Weise: "Es lässt sich in der Tat schwer eine Fauna vorstellen, die den Übergang aus dem Oligocän in das Miocän besser demonstrieren würde, wie die Fauna von Eger - Am meisten noch stimmt sie mit der Fauna unseres Mediterrans überein, von den älteren aber mit der aquitanischen Fauna der Bucht von Bordeaux und der oberoligozänen Fauna der bairischen unteren Molasse, also eben mit jenen, in denen den miocänen Elementen ein grösserer Anteil zukommt, wie in den norddeutschen Faunen, die als Typus der oberoligozänen Faunen figurieren".

Untersucht man jetzt die erwähnten "oligozänen" Formen, zeigt es sich alsbald, dass eine grosse Anzahl von ihnen auch in das Untermiocän des Nordseebeckens aufsteigen, wodurch die Voraussetzungen für das oligocäne Alter der Fauna wesentlich verändert werden.

1936 veröffentlichte J. Noszky (81) eine grössere Fauna von derselben Lokalität in seiner Arbeit: „Die Molluskenfauna des oberen Cattien von Eger«. Im ganzen werden jetzt 324 Formen beschrieben. Durch die hinzugekommenen neuen Formen wird das miocäne Gepräge der Fauna nicht vermindert.

Eine Diskussion dieser Fauna liegt ausserhalb des Rahmens dieser Arbeit, und ausserdem beschäftigte sich auch St. v. GAÁL 1938 in seinem Aufsatz: "Über die mit der Egerer gleichalterige tertiäre Molluskenfauna von BalassaGyarmat und das Oligocän-Problem" eingehend damit, mit besonderer Rücksicht auf das Alter.

Bei dem Studium der Balassa-Gyarmat'er Fauna kommt GAÁL zu der Auffassung, dass diese Fauna und zugleich auch die Fauna von Eger der untersten Stufe des Miocäns dem Aquitanien angehört.

Diese Auffassung wird durch stratigraphische und faunistische Überlegungen begründet, indem GaÁL u. a. hervorhebt, dass man den jungen Formen mehr Bedeutung zuschreiben soll als den älteren, in jüngeren Zeiten fortlebenden Formen.

GAÁL's Auffassung stimmt sehr schön überein mit dem, was oben von den "oligocänen" Formen gesagt wurde, und wird ohne Zweifel die richtige Deutung des Alters der Faunen darstellen.

Mit den beiden ungarischen Faunen, die im Folgenden zu einer Fauna zusammengefasst sind, hat Klintinghoved folgende Formen gemeinsam:

Cardium (Laevicardium) cingulatum GoldF.

Meretrix (Cordiopsis) incrassata Sow.

Thracia ventricosa PHIL.

Xenophora Deshayesii Mrch.

Natica (Lunatia) helicina BrocchI

Natica (Polinices) submammillaris D’OrB.

Turritella Geinitzi Speyer

Bittium convexorude SAcco
Chenopus speciosus v. Schloth. sp. Murex (Haustellum) paucispinatus Roth. v. Telegd

Murex (Muricantha) Deshayesii Nyst

Tiphys horridus BRocchI

Nassa (Telasco) Schlotheimi Beyrich

Surcula Steinvorthi SEmper

Pleurotoma rotata BrocchI

Pleurotoma Duchastelii Nyst

Bathytoma cataphracta Broссні

Weiter trifft man in Ungarn nahe Verwandte von:

Cardium (Laevicardium) subturgidum D'OrB.

Eulima subula D'ORBIGNY

Tritonium (Simpulum) enode Beyr.

Sveltia varicosa Brocchi

Conus (Leptoconus) Allionii Мrсн. 
Vergleichen wir nun die Fauna aus Ungarn mit der Fauna des "Altmiocäns" von Gripp, so stellt sich heraus, dass die ungarische Fauna diejenige ausserhalb des Nordseebeckens ist, welche der Fauna des "Altmiocäns" am meisten gleicht. Diese Tatsache steht in gutem Einklang mit der Annahme des aquitanischen Alters der Faunen, wie von GAÁl und Gripp angenommen wurde.

Im Folgenden sollen kurz Kautsky's recht schwache Einwendungen gegen das aquitanische Alter der Vierländer Stufe behandelt werden.

Die von Kautsky (49) hervorgehobene geringe Übereinstimmung der Fauna des Nordseebeckens mit der aquitanischen Fauna der Bucht von Bordeaux wurde schon von Gripp durch die landfeste Verbindung Englands mit dem Festland erklärt, indem so kein inniger Faunenaustausch stattfinden konnte. Diese Annahme einer Landbrücke wird übrigens von KAUtsky selbst später übernommen.

Weiter wird von Kautsky angeführt, dass eine grosse Anzahl der untermiocänen Formen im Mediterrangebiet erst im Helvétien und Tortonien auftreten. Nach dem Erscheinen der ungarischen Faunen aber ist die Anzahl solcher Formen beträchtlich vermindert worden. Übrigens kann das Auftreten oder nicht Auftreten solcher Formen meiner Meinung nach sehr gut klimatisch bedingt sein. Nun meint Kautsky aber auf Grund des Angeführten, die Vierländer Stufe ins Burdigalien versetzen zu können, indem er zum Schluss in seiner Auseinandersetzung den »indirekten Beweis« führt, dass die Faunenunterschiede zwischen der Vierländer und Hemmoorer Stufe zu gering seien, als dass die dazwischen liegenden Braunkohlensande das Burdigalien repräsentieren könnten.

$\mathrm{Zu}$ KaUtsky's Anschauungen ist es wichtig hervorzuheben, dass der von GrIPP $(35,37)$ erwähnte allmähliche Übergang des marinen Oberoligocän in das marine Untermiocän bei seinen Erwägungen nicht berücksichtigt wird. Gripp betont, dass nichts auf eine Unterbrechung in der Sedimentation zwischen Oberoligocän und Untermiocän hinweist. Die logische Folge dieser Tatsache wird dann sein, falls man, wie es üblich ist, das Oberoligocän mit dem Cattien gleich setzt, dass das Untermiocän mit dem Aquitanien parallelisiert wird $\left.^{1}\right)$.

$\mathrm{Zu}$ dem indirekten Beweis muss erstens hervorgehoben werden, dass die Mächtigkeit der Braunkohlensande nicht die Altersfrage beeinflussen kann. Was die grosse Verwandtschaft der Faunen der Hemmoorer und Vierländer Stufe betrifft, so möchte ich nur hervorheben, dass die Braunkohlensande, wie man sie in Norddeutschland über der Vierländer Stufe findet, in Dänemark nicht an dieser Stelle in der Schichtenfolge entwickelt sind. Im Gegenteil scheint in Dänemark das Miocän in seinem grössten Teil marin zu sein. Es mag hier nur auf die von Ravn (95) veröffentlichten Bohrprofile von Varde und Viborg hingewiesen $\operatorname{sein}^{2}$ ).

Man darf deshalb annehmen, dass die Braunkohlensande Norddeutschlands eine örtliche Entwicklung darstellen, sodass die durch sie angezeigte Regression des Meeres nicht das ganze Nordseebecken betroffen hat. Unter dieser

1) Natürlich kann aber der unterste Teil der Vierländer Stufe, wie Gripp es meint, sehr gut ein wenig älter als das Aquitanien sein.

2) Die von Ravn (95) erwähnten und von GRIPP (37) hervorgehobenen Sandablagerungen mit Braunkohle bei Viborg liegen weiter oben in der Schichtenfolge und sind wahrscheinlich viel jünger. Da ich weiss, dass Herr stud. mag. K. Dreyer Jørgensen zur Zeit diese Ablagerungen studiert, werde ich mich vorläufig von einer weiteren Diskussion fern halten. 
Voraussetzung konnte die Fauna des Untermiocäns weiter von Norddeutschland entfernt, immer noch aber im Nordseebecken fortleben, wodurch die verhältnismässig geringen Unterschiede der Fauna der Vierländer und der Hemmoorer Stufe erklärt werden, indem ein überlebender Teil der Fauna des Untermiocäns mit etlichen neuen Formen während der Hemmoorer Transgression wieder nach Süden wanderte.

Ehe wir die Hemmoorer Stufe verlassen, muss darauf aufmerksam gemacht werden, dass Kautsky's Parallelisierung dieser Stufe mit der zweiten Mediterranstufe zu seiner gleichzeitigen Annahme des helvetischen Alters der Hemmoorer Stufe jetzt in Widerspruch steht, da die zweite Mediterranstufe nach Schaffer (103) ins Tortonien gehört. Das helvetische Alter der Hemmoorer Stufe muss jetzt eine Parallelisierung mit den Grunder Schichten mit sich führen.

Übersichtshalber sei folgendes Schema mit den besprochenen mittel- und untermiocänen Faunen aus Nord- und Südeuropa angeführt.

Beim Abschluss dieses Abschnittes soll betont werden, dass wir sowohl im ungarischen Becken als auch im Nordseebecken an der Wende OligocänMiocän Faunen finden, die die beiden Zeitabschnitte mit einander verbinden, alte Formen leber weiter, und die ersten Formen des Miocäns erscheinen im Faunenbild. Wir erlangen hierdurch ein wertvolles Hilfsmittel zur Beleuchtung der Übergangszeit und zu der Synchronisierung der Ablagerungen, die in Nord- und Südeuropa in diesem Zeitraume gebildet wurden.

\begin{tabular}{|c|c|c|c|}
\hline & $\begin{array}{c}\text { Norddeutschland } \\
\text { nach Gripp }(37,38) \text { KaUtSKY } \\
(49) \text { und E. Koch }(57) \text {. }\end{array}$ & $\begin{array}{l}\text { Wiener Becken, Ungarn } \\
\text { und Ober Schlesien } \\
\text { nach ScHAFFER (102), GAÁL } \\
\text { (26) und KITTL (53). }\end{array}$ \\
\hline $\begin{array}{l}\text { Ober- } \\
\text { miocän }\end{array}$ & Pontien & & \\
\hline \multirow{3}{*}{$\begin{array}{l}\text { Mittel- } \\
\text { miocän }\end{array}$} & Sarmatien & Reinbeker Stufe & Cerithienschichten \\
\hline & Tortonien & Obere Braunkohlensande & Zweite Mediterranstufe \\
\hline & Helvétien & $\begin{array}{c}\text { Hemmoorer Stufe } \\
\text { Hamburger Ton }\end{array}$ & Grunder Schichten \\
\hline \multirow[b]{2}{*}{$\begin{array}{l}\text { Unter- } \\
\text { miocän }\end{array}$} & Burdigalien & Untere Braunkohlensande & Erste Mediterranstufe \\
\hline & Aquitanien & Vierländer Stufe & $\begin{array}{l}\text { Marine Schichten bei } \\
\text { Ostrau-Karwin in Ober- } \\
\text { schlesien und bei Eger und } \\
\text { Balassa-Gyarmat im } \\
\text { ungarischen Becken }\end{array}$ \\
\hline $\begin{array}{c}\text { Ober- } \\
\text { oligocän }\end{array}$ & Chattien & & \\
\hline
\end{tabular}




\section{Das Becken von Bordeaux in Westfrankreich.}

Mit den untermiocänen Faunen des Beckens von Bordeaux, dem Aquitanien und Burdigalien, die hier zusammengefasst sind, hat Klintinghoved folgende Formen gemeinsam:

Limopsis aurita BrocchI

Panopaea Ménardi Deshayes

Dentalium (Antale) vitreum Sснвӧт.

Xenophora Deshayesii Mich.

Pyramidella plicosa Bronn

Newtoniella (Seila) cyrtogyra Cossm. et PEyr.

Cypraea (Zonaria) amygdalum

BROCCHI
Cassidea (Semicassis) Rondeletii Bast. Tiphys horridus Brocchi

?Pleurotoma rotata BRocchI

Bathytoma cataphracta BrocchI

Scaphander lignarius L. var. Grateloupi

Mich.

Bullinella cylindracea PENN.

Roxania utriculus BRocchi

Vaginella depressa DAUDIN

Ausserdem trifft man nahe Verwandte von Nucula nucleus L. var. Hanleyi Winckw. und Bittium convexorude Sacco.

Die verhältnismässig geringe Anzahl der gemeinsamen Formen wurde schon von Gripp (37) durch das Fehlen einer Meeresverbindung zwischen England und Frankreich erklärt. Die gemeinsamen Formen sind solche mit grosser geographischer oder vertikaler Verbreitung und können nicht als Zeugen eines Faunenaustausches gelten, sondern müssen entweder als Nachkommen der endemischen oligocänen Faunen oder als Formen gedeutet werden, die aus einem dritten Meeresgebiet eingewandert sind. So möchte ich annehmen, dass Cypraea amygdalum über das Mittelmeer in das Nordseebecken gelangt ist und nicht über Westfrankreich.

Nach Kautsky $(49,50)$ war zur Zeit der Hemmoorer Stufe der Pas de Calais wahrscheinlich wieder hergestellt.

\section{Vergleich mit tertiären Faunen in Nordamerika und Ostgrönland.}

\section{Nordamerika.}

Bevor wir zu einem Vergleich mit Ablagerungen jenseits des Atlantischen Ozeans übergehen, sei vorausgeschickt, dass hier nicht von so engen Beziehungen die Rede sein kann wie bei den besprochenen europäischen Ablagerungen, da die für diesen Zweck notwendige Synchronisierung einfach nicht mit nötiger Genauigkeit vorliegt.

Die Ablagerungen, die hier Interesse haben, sind The Chesapeake Series von Maryland sowie The Tampa Formation und The Alum Bluff Group von Florida, deren marine Molluskenfaunen von DaLL $(18,19)$ und Julia GarDENER (28) behandelt wurden.

Nach den Anschauungen der amerikanischen Geologen (121) sind The Tampa Formation und Alum Bluff Group wahrscheinlich mit dem Aquitanien bzw. Burdigalien-Helvétien, The Chesapeake Series ${ }^{1}$ ) mit dem Tortonien Europas zu vergleichen.

$\left.{ }^{1}\right)$ Diese Schichtenfolge wird in Calvert-, Choptank- und St. Marys-Formation gegliedert. 
Die Genauigkeit dieser Parallelisierung hat in diesem Fall nicht so grosse Bedeutung, da die Formen vom Klintinghoved, die zum Vergleich mit Formen aus Nordamerika herangezogen werden, in Europa eine vertikale Verbreitung vom Oberoligocän bis zum Mittelmiocän besitzen. Da man wohl annehmen darf, dass die amerikanischen Parallelisierungen im Grossen und Ganzen richtig sind, lässt sich also ein Vergleich anstellen.

Folgende Formen sind einander sehr ähnlich.

Klintinghoved:

Nucula nucleus L. var. Hanleyi

Winckw.

Yoldia glaberrima v. Münst.

Abra angulosa ReN.

Panopaea Menardi Deshayes

Thracia ventricosa PHIL.

\author{
Nordamerika (Maryland): \\ Nucula proxima SAY \\ Yoldia laevis SAY \\ Abra marylandica GLENN \\ Panopaea Whitfieldi DALL \\ Thracia Conradi Couthouy
}

KaUtsky (49 p. 220) versucht eine Parallelisierung von insgesamt 15 Formen zu jeder Seite des Ozeans, darunter auch die Mehrzahl der obigen Formen. Wichtig ist es, dass von den amerikanischen Formen 13 den nördlicheren Chesapeake Series, aber nur 2 Formen dem südlicheren Miocän Floridas entstammen.

Ehe wir weitere Schlüsse ziehen, sei eben in Kürze auf die Arbeiten DaLL's eingegangen.

Bei dem Studium der miocänen Faunen der Ostküste Nordamerikas gelangt DALL (19) zu der Anschauung, dass während des Miocäns im nördlichen Atlantischen Ozean ähnliche Meeresströme herrschten wie heute, nur durch eine Art "Parallelverschiebung», die auf ein anderes Klima hinweist, wichen sie von den rezenten ab. Es existierte also damals ein kalter Nordstrom und ein miocäner Golfstrom.

Weiter ist Dall der Anschauung, dass die nordeuropäischen Faunen weniger boreal waren als die Faunen der Chesapeake Series, dass diese Faunen also in kälterem Wasser lebten, eine Anschauung, die auch jetzt den Tatsachen entsprechen dürfte. Und doch zeigt Maryland zu den nordeuropäischen Faunen grössere Beziehungen als zu den südeuropäischen (DALl 19 Seite C L).

In seinem Abschnitt über die Beziehungen zwischen Hemmoor und Nordamerika folgert Kautsky (49 p. 221) in folgender Weise:

"Die Beziehungen der Fauna der nordamerikanischen Ostküste zu jener von West-Frankreich sind - obwohl ebenfalls bemerkbar - bedeutend schwächer als die zum Nordseebecken. Dies erfordert zwischen Maryland und dem Nordseebecken eine Meeresverbindung nördlich von England. Das nordatlantische Festland mit seinen miocänen Braunkohlenbildungen (SuEss) war, wie dies die zahlreichen Basaltergüsse bezeugen, im Zerbrechen, und in dem so entstandenen Archipel konnte leicht ein solcher Faunenaustausch stattfinden".

Wir werden jetzt zu einer Wertung der »Parallelformen" der Faunen und gleichzeitig zu den Schlüssen, die in Verbindung hiermit zu ziehen sind, übergehen.

Die Parallelformen sind möglicherweise zum Teil mit einander ident, obgleich dies noch nicht mit Sicherheit festgestellt wurde. Nehmen wir aber an, dass von identischen Formen die Rede ist ${ }^{1}$ ), so ist meiner Meinung nach

1) $\mathrm{Zu}$ solchen Formen bin ich geneigt Yoldia laevis, Thracia Conradi und Panopaea Whitfieldi mit ihren europäischen Parallelformen und zugleich auch etliche der von KAUTSKy aufgezählten Formen zu rechnen. 
hieraus der einzig richtige Schluss zu ziehen, dass eine Meeresverbindung (vor oder während der Ablagerungen der die Faunen enthaltenden Schichten) zwischen den beiden Gebieten bestand, oder, was übrigens auf dasselbe hinauskommt, dass die beiden Meeresgebiete durch ein drittes verbunden wurden. Dieses kann dann möglicherweise der Ausgangsort der Formen sein ${ }^{1}$ ). In der Möglichkeit, dass einzelne Formen vielleicht zu beiden Seiten auftreten, liegt meiner Meinung nach keine Begründung der Annahme eines Faunenaustausches, indem ich dabei einen Austausch verstehe, der zu entschiedene Mischfaunen führt z. B. wie bei der besprochenen Aquitanien-Fauna aus Ungarn. Weiter ist es meiner Meinung nach nicht empfehlenswert, in dieser Verbindung von einem nordatlantischen Festland $\mathrm{zu}$ reden, erstens da ein solches als sehr problematisch gelten darf, und zweitens da es in keiner Weise eine notwendige Voraussetzung für das Auftreten gleicher Formen an beiden Seiten des Ozeans ist.

Unter der Voraussetzung, dass einzelne der Parallelformen identisch sind, können wir uns einer Deutung des Auftretens gleicher Formen an der Ostund Westküiste des Ozeans zuwenden.

Es sei auf die besprochene Theorie DALI's der Strömungsverhältnisse aufmerksam gemacht. Der kalte Nordstrom begünstigte das verhältnismässig weite Vordringen der kalten Formen nach Süden längs der nordamerikanischen Ostküste, was insbesondere seinen Einfluss auf die Fauna von Maryland ausübte. Die wärmere Fauna von Florida dagegen wurde davon nicht berührt. Werfen wir jetzt einen Blick auf die Verbreitung der Parallelformen (wir können auch hier KaUtsky's Formen (49 p. 220) mitnehmen), so zeigt es sich, dass diese mit Ausnahme zwei der Formen Kaursky's, die aus Florida sind, alle aus dem Miocän Marylands stammen Da die Anzahl der Parallelformen somit in Maryland weit grösser ist als in Florida, gelangt man zu dem Schluss, mit grösserer Wahrscheinlichkeit annehmen zu dürfen, dass in Maryland unter den Parallelformen wirklich identische Formen mit solchen des Nordseebeckens vorkommen.

Indem ich immer noch auf die Verhältnisse der Meeresströmungen verweise, scheint mir in diesem Fall das Auftreten derselben Form in Maryland und im Nordseebecken die richtige Deutung dadurch zu erfahren, dass es sich um Elemente nördlicherer Faunen mit gleichzeitig grosser geographischer Verbreitung handelt. Mit anderen Worten: Diese Formen hatten im nördlichen Atlantischen Ozean ihr natürliches Verbreitungsgebiet, von wo sie an den Küsten beiderseits des Ozeans nach Süden wanderten, ähnlich wie man im rezenten Atlantischen Ocean die Verbreitung der nordischen Formen ${ }^{2}$ ) an den Küsten Nordamerikas beobachten kann (SARs 98, BrögGer 11). Die Zahl der rezenten gemeinsamen Formen an beiden Seiten des Ozeans nimmt nach Süden zu ab, so dass wir weiter südlich - in Westindien und im Mittelmeer mit Ausnahme von ganz vereinzelten pelagischen oder allgemein verbreiteten Formen keine gemeinsamen Formen vorfinden (BucQuoy, 12, II, p. 754). Hierzu finden wir auch schon im Miocän eine Parallele, wo die Faunen von Florida und Westindien keine Formen mit dem miocänen Mittelmeer gemeinsam haben (W. P. Woodring 129), die Beziehungen erstrecken sich nur auf die Genera.

1) Es wird hier von der Möglichkeit abgesehen, dass die gleiche Form zu gleicher Zeit an zwei verschiedenen Stellen entsteht, da dies mir in diesem Falle zu unwahrscheinlich vorkommt.

$\left.{ }^{2}\right)$ Damit sind wie bei Nordmann (72 S. 211) arktische und boreale Formen gemeint. 
Man kann also nicht von einem Faunenaustausch zwischen Maryland und dem Nordseebecken sprechen, wir haben es vielmehr mit Formen der Aussenzone einer nördlicheren Fauna zu tun.

Diese Deutung entspricht meiner Meinung nach den Tatsachen, dass so wenig Formen gemeinsam sind, und dass die Naturverhältnisse des Atlantischen Ozeans im Miocän in so vielen Punkten den rezenten gleichen. Es ist deshalb nicht notwendig, dass man die Deutung mit einem hypothetischen Festland verbindet, da ja auch die biologische Seite der Wanderungen der rezenten Formen zu ungenügend untersucht ist, als dass man etwa deshalb gezwungen wäre, sich auf ein solches Festland zu stützen. Das einzig Verantwortliche ist die Annahme einer Meeresverbindung ${ }^{1}$ ).

\section{Ostgreönland.}

Was einleitend bei der Besprechung der nordamerikanischen Faunen gesagt wurde, gilt bzgl. Ostgrönlands in noch höherem Masse. Man kennt hier marines Tertiär nur in der Gegend von Kap Dalton und südlich hiervon (RAvn 1903 und 1933). Das Alter der Fauna ist unsicher und wurde von RAvN infolge einer gewissen Ähnlichkeit mit dem Eocän des Londoner Beckens versuchsweise hiermit verglichen.

Die Besprechung der Beziehungen der Klintinghovedfauna zu den Faunen in anderen Gebieten abschliessend, möchte ich kurz darauf aufmerksam machen, dass auch Ostgrönland gewisse Übereinstimmungen mit den nordeuropäischen oligocänen und miocänen Faunen aufweist. Doch sei im Voraus gesagt, dass noch keine sichere Altersbestimmung der Kap Dalton Fauna vorgenommen werden kann.

Zwischen den äusserst wenigen bestimmbaren Formen findet man Chenopus speciosus v. Sснцотн sp., der zu var. Margerini DE Koninck gerechnet werden muss. Gewiss ähnelt diese Form Chenopus Margerini DE Koninck aus dem London-Eocän (Starkie Gardner 29), weicht aber durch den Bau der Mündung davon ab, da die Innenlippe sich weiter oben an den Umgängen anlegt (RAvn 1903). Hierdurch schliesst sich die Form an die nordeuropäischen oligocänen und untermiocänen Formen an. Von den übrigen Fossilien konnten nur wenige bestimmt werden, sodass sich stratigraphisch nur wenige Anhaltspunkte ergeben. Es soll in diesem Zusammenhang nur darauf afmerksam gemacht werden, dass die grösste Zahl der Genera auch im Oligocän und Miocän Nordeuropas Vertreter hat, besonders seien Cyprina und Donax hervorgehoben.

Natürlich haben die Formen keinen grossen stratigraphischen Wert, ich möchte jedoch hervorheben, dass die Möglichkeit besteht, dass die Kap Dalton Serie von einem jüngeren, vielleicht zwischen Mitteloligocän und Untermiocän liegenden Alter ist. Ich möchte gleichzeitig wieder die nahe Verwandtschaft des Coeloma incarinatum nov. sp. vom Klintinghoved zu dem

1) Ebenso liegt meiner Meinung nach ungenügender Befund vor, wenn man auf Grund einer gewissen Übereinstimmung in der Verteilung der Genera im Miocän des Mittelmeeres und Westindiens geneigt ist, eine mehr oder weniger ausgesprochene Landverbindung zwischen den beiden Gebieten herzustellen (Schaffer 101 I p. 268, Kautsky 51 p. 62, Woodring 129 p. 430). Nur eine Meeresverbindung kann hier in Frage kommen. Auch kann nicht von Faunenaustausch die Rede sein, da dieser sich nicht nur in übereinstimmender Verteilung der Gattungen zeigen soll, sondern es sollen auch beiderseits identische Formen vorkommen. 
Coeloma bicarinatum RAvn aus Ostgrönland hervorheben, da diese Verwandtschaft inniger ist als die Verwandtschaft des Coeloma bicarinatum RAvN zu Portunus incerta Bell (Ravn 1903 p. 139), wo es sich um verschiedene Genera handelt.

Der Vollständigkeit halber sei eine Bemerkung LóRenthey's, die er bei der Beschreibung des Genus Coeloma machte, zitiert. Nach LőnEntmey deutet die Entwicklungstendenz bei Coeloma darauf hin, dass die Lobulierung der Oberfläche des Cephalothorax stärker betont wird. Unter der Voraussetzung der Richtigkeit dieser Annahme ${ }^{1}$ ) folgert dieser Verfasser: ( 70 p. 242) "Auf Grund dieser allgemeinen Entwicklungstendenz der Gattung Coeloma müsste das in seinem Alter unbestimmte Coeloma Grönlands ins Mittel- oder Oberoligozän gestellt werden, da diese Form eine sehr ausgeprägte Gliederung besitzt«.

Zusammenfassend kann gesagt werden, dass die Kap Dalton-Serie mit gewisser Wahrscheinlichkeit als jünger als Eocän angesehen werden darf, und dass man die Serie mit Vorbehalt in den Zeitraum Mitteloligocän-Untermiocän stellen darf.

Von grossem Interesse würde deshalb die gelegentliche genauere Untersuchung der Kap Dalton-Serie sein, da das Alter dieser Schichten sehr wichtig ist, erstens für die Festlegung des Alters der Eruptive, worin die Schichten eingebettet liegen, und zweitens für die Parallellisierung europäischer und amerikanischer Ablagerungen.

\section{Palaeogeographische Schlussfolgerungen.}

Die Klintinghoved-Fauna zeigt u. a. sehr nahe Beziehungen zu den untermiocänen Faunen in Südosteuropa (Wiener Becken und besonders das ungarische Becken). Eine Anzahl Formen tritt im Klintinghoved und Südeuropa gleichzeitig auf, ist aber noch nicht im Becken von Bordeaux gefunden worden, was auch Kautsky bzgl. Formen der Hemmoorer Fauna feststellte $(49,50)$.

Diese Formen sind:

Cardium cingulatum GoLDF.

Thracia ventricosa PHIL.

Natica (Lunatia) helicina Brocchi

Natica (Polinices) submammillaris

D’Orв.

Turritella Geinitzi Speyer

Chenopus speciosus Sснцотн, var.
Murex (Haustellum) paucispinatus

Roth v. Telegd

Murex (Muricantha) Deshayesii Nyst

Nassa (Telasco) Schlotheimi BEyr.

Surcula Steinvorthi SEMPER

Pleurotoma Duchastelii Nyst

Von diesen müssen Turritella Geinitzi, Chenopus speciosus, Nassa Schlotheimi und vielleicht auch Thracia ventricosa als typisch für das Nordseebecken angesehen werden; Murex paucispinatus und Cypraea amygdalum²) dagegen müssen als südliche Formen angesehen werden.

Unter weiterer Berücksichtigung der Tatsache, dass wir im ungarischen Aquitanien eine deutliche Einwanderung auch von anderen Formen aus dem

1) Von der Gattung Coeloma kennt man vorläufig (Lö́nenthey 70 p. 241) 14 Spezies, mit C. incarinatum also 15 .

2) Diese Form kommt auch im Becken von Bordeaux vor. 
Nordseebecken haben, ergiebt sich die logische Konsequenz, dass zwischen den beiden Gebieten eine Meeresverbindung bestanden hat, wie auch schon von Roth v. Telegd angenommen wurde.

Da viele der gemeinsamen Formen der Gebiete nicht in den gleichalterigen Ablagerungen bei Bordeaux vorkommen, und da der Pas de Calais nach GripP zu dieser Zeit nicht existierte, lässt sich ein Austausch über Westfrankreich schwer vorstellen, da die südlichen Formen in diesem Fall weit nördlich bis zum Meere zwischen Norwegen und England - wandern mussten. Wahrscheinlicher ist es anzunehmen, dass der Faunenaustausch zwischen Ungarn und dem Nordseebecken über eine Meeresstrasse, die von Ungarn über das Wienerbecken nach Mähren, Ober Schlesien, Posen, Norddeutschland, Jütland und die Nordsee verlief, stattgefunden hat.

Eine solche Hypothese könnte gewagt erscheinen, da die Befunde noch ziemlich ungenügend sind. Betrachtet man aber das bezeichnete Gebiet der Meeresverbindung, so findet man in ihm eine dritte Mischfauna vom Alter der Klintinghovedfauna und der ungarischen Faunen, nämlich die Ostrau-Karwiner Fauna KitTL's.

Mit Klintinghoved hat diese Fauna u. a. die Genotia trochlearis gemeinsam. Die unter der Beschreibung dieser Form hervorgehobene sonderbare Verbreitung lässt sich schön durch die Meeresverbindung erklären. Diese Form wanderte wie die Turritella Geinitzi (Косн 54 1894) bis nach Siebenbürgen.

Noch eine Lokalität möge genannt sein, nämlich die Bohrung Xions (Jentsch 47), wo marines Miocän unter Posener Ton erbohrt wurde. Wird für den Posener Ton ein pliocänes Alter angenommen (P. G. Krause 1933 p. 65), so kann das liegende marine Miocän entweder Mittel- oder Untermiocän sein (Linstow 69 p. 105). Werfen wir einen Blick auf die Entwicklungsgeschichte der Meeresstrasse, so müssen wir annehmen, dass sie (vielleicht mit Unterbrechungen) sowohl im Untermiocän als auch im Mittelmiocän (Kautsky 49,50) bestanden hat. Die Salzablagerungen von Wieliczka sind woh] bei der Eintrocknung gewisser Teile des grossen Beckens, das das Meer vor dem Tortonien überflutete, entstanden. Nachdem das Posener Becken vom Meere abgeschnitten wurde, - dies kann im Obermiocän oder Unterpliocän geschehen sein -, wurde es im Laufe des Pliocäns von den mächtigen Schichten des Posener Tons und den begleitenden Schichten des Kieseloolithes aufgefüllt.

\section{Das Klima des Untermiocäns.}

Die Frage, unter welchen klimatischen Verhältnissen die Fauna des Untermiocäns lebte, ist schwierig zu erörtern.

Folgende heute noch lebenden Formen der Klintinghovedfauna: Nucula nucleus L., Abra angulosa Rev. (= A. prismatica Mtg.), Cuspidaria costellata Desh., Natica helicina Brocc. Scaphander lignarius L., Bullinella cylindracea Penn. und Roxania utriculus Brocc. haben alle eine grosse geographische Verbreitung, indem sie im Mittelmeer und im Atlantischen Ozean längs der Küsten von Spanien, Frankreich, Grossbritannien und Südnorwegen leben. Cuspidaria costellata und Bullinella cylindracea dringen weit nach Süden, bis zu den kanarischen Inseln und Madeira vor. Diese Formen leben also so- 
wohl in borealen als auch in lusitanischen Gebieten und sagen deshalb nichts Sicheres über das untermiocäne Klima aus.

Obgleich diese Formen uns keine positive Auskunft gaben, deuten sie dennoch zusammen mit den Gattungen Solarium, Polinices, Pyrula, Cypraea (Zonaria), Tritonium, Murex, Tiphys, Leptoconus und Pleurotoma (Hemipleurotoma) daraufhin, dass die Fauna des Untermiocäns in einem Meere lebte, das bedeutend wärmer war als die heutige Nordsee. Wir müssen mit ähnlichen Temperaturverhältnissen rechnen, wie wir sie jetzt an den Küsten Südfrankreichs und Nordspaniens finden, obgleich es schwierig ist, sich mit Sicherheit darüber zu äussern, da man nicht weiss, ob die Formen dieser Gattungen sich zu der Temperatur ebenso wie die rezenten nächsten Verwandten verhielten.

Man darf sich die übrigen Naturverhältnisse doch nicht völlig so vorstellen wie an den Küsten Südwesteuropas, da höchstwahrscheinlich nicht ein offenes Meer vorlag. Im Gegenteil muss man, wie im Abschnitt über die Palaeogeographie erörtert wurde, mit einer Meeresstrasse rechnen, einer Art Mittelmeer, das die damalige Nordsee mit dem damaligen Mittelmeer verbunden hat.

In Verbindung hiermit ist es von Interesse, die Anschauungen O. JEssen's (48) über das Miocän-Klima zu berühren. Durch den Vergleich der Verwitterungsrinden des deutschen Mittelgebirges mit ähnlichen Bildungen aus den afrikanischen Tropen kommt dieser Verfasser zu der Anschauung, dass das Klima Mitteldeutschlands im Miocän etwa von derselben Art gewesen sein muss wie das rezente Klima Floridas nämlich mit Sommerregenzeit und Wintertrockenzeit. Zum Vergleich werden folgende Durchschnittstemperaturen gegeben: Frühling $21^{\circ}$, Sommer $28^{\circ}$, Herbst $23^{\circ}$, Winter $15^{\circ}$.

Dieser Vergleich kann aber meiner Meinung nach deshalb nicht durchgeführt werden, weil wir in Florida ein Gebiet mit subtropischem Wald und Savanne an der Ostseite eines Festlandes vorfinden. Für das miocäne Norddeutschland dagegen muss mit grösster Wahrscheinlichkeit angenommen werden, dass die Westseite eines Festlandes vorlag. Wir dürfen deshalb sicher für die südliche miocäne Nordsee sowohl ein etwas kälteres wie auch trockeneres Klima annehmen an Stelle eines Klimas, das demjenigen des heutigen Floridas ähnelt. Diese Annahme stimmt damit überein, dass man heute im subtropischen Gebiet an den Westküsten der Festländer Gebiete mit subtropischem Winterregen findet. 


\section{Litteratur.}

1. Andersen, S. A.

2. Basterot, M. DE.

3. Bayle et Villa.

4. Bell, Th.

5. Bellardi et F. SAcco. 1872-1904. I Molluschi dei terreni terziari del Piemonte e della Liguria. Torino 1872-1904. Parte I 1872, II 1877, III 1882, IV 1884, V 1890, VI 1890 , VII 1890, VIII 1891, IX 1891, X 1891, XI 1892, XII 1892, XIII 1893, XIV 1893, XV 1894, XVI 1894, XVII 1895, XVIII 1895, XIX 1895, XX 1896, XXI 1896, XXII 1897, XXIII 1897, XXIV 1897, XXV 1898, XXVI 1898, XXVII 1899, XXVIII 1900, XXIX 1901, XXX 1904.

6. Beyrich, E.

7. Bogsch, L.

8. Brocchi, G. B.

9. Bronn, H. G.

10. Bronn, H. G.

11. Brögger, W. C.

12. BucQuoy, E. Ph. Dautzenberg et G. Dollfus.

13. Carter, James

1937. Oligocænet ved Aas. Meddelelser fra Dansk Geologisk Forening. Bd. 9, p. 218. København.

1825. Mémoire géologique sur les environs de Bordeaux. T. II; Mém. de la Soc. d' Hist. Nat. de Paris.

1854. Note géologique sur le province d'Oran. Bull. de la Soc. géol de France, 2 Ser. IX.

1857. A Monograph of the Fossil Malacostracous Crustacea of Great Britain. Part I. Crustacea of the London Clay. Palaeontographical Society. London. Die Conchylien des norddeutschen Tertiärgebirges. Pag. $1-80,1853$, pag. $81-176,1854$, pag. 177-296, 1856 et pag. 297-336, 1857 Berlin.

1936. Tortonische Fauna von Nógrádszakál. Mitteilungen a. d. Jahrbuch d. Kgl. Ungar. Geolog. Anstalt. Bd. XXXI, Heft. 1. Budapest.

1814. Conchiologia fossile subappenina. Milano (1814) 1843.

1831. Italiens Tertiär-Gebilde und deren organische Einschlüsse. Heidelberg.

1838. Lethaea Geognostica. Bd. II. Stuttgart.

1900 - 01 . Om de senglaciale og postglaciale nivăforandringer i Kristianiafeltet (Molluskfaunaen). Norges Geologiske Undersøgelse. Nr. 31. Kristiania.

1882-1898. Les Mollusques Marins du Roussillon. T. I Gastropodes 1882-1886. T. II Pélécypodes 1887-1898. Paris.

1898. A Contribution to the Palaeontology of the Decapod Crustacea of England. The Quarterly Journal of the Geological Society. Vol. LIV, p. 15. London. 
14. Cossmann, M. 1895-1912. Essais de Paléontologie comparée. T. I-IX. $1895-96-99-1901-03-04-06-09-$ 12. Paris.

15. Cossmann et J. Lambert. 1884. Étude Paléontologique et Stratigraphique sur le Terrain Oligocène Marin aux Environs d'Étampes. Mémoires de la Soc. Géol. de France. 3. Sér. t. III. Paris.

16. Cossmann, M. 1909-34. Conchologie Néogénique de l'Aquitaine. Actes de et Peyrot. (Peyrot depuis 1925) la Société Linnéenne de Bordeaux. Vol.: LXIII 1909, LXIV 1910, LXV 1911, LXVI 1912, LXVIII 1914, LXIX 1915-16, LXX p. 5180 1917, p. $181-491$, 1918; LXXIII 1921, LXXIV 1922, LXXV 1923, LXXVII 1925 , LXXVIII 1926, LXXIX 1928, LXXXII 1930, LXXXIII 1931, LXXXIV 1932, LXXXV 1933, LXXXVI 1934. Bordeaux.

17. Czarnoki, J.

1935. O wasżniejzych zagadnieniach stratygrafji i paleogeografji polskiego tortonu. Die wichtigsten stratigraphischen und paläogeographischen Probleme des polnischen Tortons. (Zusammenfassung). Bull. du Service Géologique de Pologne. Vol. VIII Livr. 2. Warszawa p. 179.

18. DALL, W. H.

19. DALl, W. H.

20. Defrance.

21. Deshayes

22. ERIKSEN, KNUD.

23. Fischer, P.

24. Friedberg, W.

25. Friedberg, W.

26. GAÁL, I. (ST).

27. Gardener, Julia.
1890-98. Contributions to the Tertiary Fauna of Florida. I 1890, II 1892, III 1895, IV 1898. Transactions of the Wagner Free Institute of Science of Philadelphia.

1904. The Relations of the Miocene of Maryland to that of other Regions and to the Recent Fauna. Maryland Geol. Survey; Miocene, p. CXXXVIII. Baltimore.

1817. Dictionaire des sciences naturelles. Vol. VI.

1832. Expédition scientifique de Morée. Tom. III.

1937. En Foreløbig Meddelelse om Tertiæret ved Brejning paa Sydsiden af Vejle Fjord. Mit einer Zusammenfassung. Meddelelser fra Dansk Geologisk Forening. Bd. 9, p. 937. København.

1887. Manuel de Conchyliologie. Paris.

1933. Przyczynki do znajomosci miocenu Polski Beiträge zur Kenntnis des Miocäns von Polen. I Teil. Ann. Soc. Géol. Poıonais, Vol. IX.

1933. Beitrag zur Kenntnis d. Salzformation von Wieliczka. Jahrb. d. Poln. Geol. Ges. Jahrg. 1933.

1938. Az egriekkel azonos harmadkori puhatestüek Balassa-Gyarmaton és az oligocén-kérdés. Über die mit der Egerer gleichalterige tertiäre Molluskenfauna von Balassagyarmat und das Oligozän-Problem. Annales Historico-Naturales Musei Nationalis Hungarici. Vol. XXXI. 193738. Budapest.

1924. Coastal Plain and European Miocene and Pliocene Mollusks. Bull. of the Geol. Soc. of America. Vol. 35. No 4, p. 857. Washington. 
28. Gardener, Julia.

29. Gardner, J. Starkie.

30. Gignoux, M.

31. Glenn, L. C.

32. GoldFuss

33. Gottsche, C.

34. Gotrsche, C.

35. GRIPP, KARL.

36. Gripp, KArL.

37. Gripp, KarL

38. Gripp, Karl.

39. Gripp, Karl.

40. Gripp, KarL。

41. Gry, Helge

42. Harder, Poul.

43. Harmer, F. W.

44. Hoernes, M.
1926 - 37. The Molluscan Fauna of the Alum Bluff Group of Florida. Geol. Surv. of the United States. Dep. of the Interior. Prof. Paper No. 142. A-F. A-D 1926, E 1928, F 1937. Washington.

1884. British Eocene Aporrhaïdæ. The Geological Magazine. New Series. Decade III. Vol. I. p. 529 pl. XVII. London.

1913. Les Formations Marines Pliocénes et Quaternaires de l'Italie du Sud et de la Sicile. Annales de l'Université de Lyon. Nouv. Sér. I. Fasc. 36. Lyon.

1904. Systematic Paleontology of the Miocene deposits of Maryland. Maryland Geol. Survey. Miocene, p. 274 (Pelecypoda). Baltimore.

1833 - 40. Petrefacta Germaniae II-III. Düsseldorf.

1883. Die Sedimentaergeschiebe der Provinz Schleswig-Holstein. Yokohama.

1887. Die Molluskenfauna des Holsteiner Gesteins. Bd. V der Abhandl. aus dem Gebiete der Naturwissenschaften des Naturwiss. Vereins in Hamburg. Hamburg.

1912. Das Tertiär in den Vierländer Bohrungen. (under E. Косн).

1914. Über eine untermiozäne Molluskenfauna von Itzehoe. Jahrb. der Hamburgischen Wissenschaftlichen Anstalten. XXXI. 1913. 5 Beiheft. Mitt. a. d. Mineral.-Geol. Inst. in Hamburg. Hamburg.

1915. Uber das marine Altmiocän im Nordseebecken. Neues Jahrbuch f. Min., Geol. u. Paläontologie. Beilage Bd. XLI, p. 1. Stuttgart.

1920. Stratigraphie des Jungtertiärs in Nordwestdeutschland (under E. Косн.).

1933. Geologie von Hamburg und Umgeburg. Hamburg.

1940. Geologie und Lagerstätten der Tertiärformation im Wirtschaftsgebiet Niedersachsen. Wirtschaftswissensch. Gesellsch. zum Studium Niedersachsens. E. V. Reihe A. Heft 53. Oldenburg i. O.

1935. Se under V. MAdSEn.

1913. De oligocæne Lag i Jærnbanegennemskæringen ved Aarhus Station. Danmarks Geol. Undersøgelse. II Række. Nr. 22. København.

1914-19. The Pliocene Mollusca of Great Britain. Vol. I. Part I, (pag. 1-200) 1914, II (pag. 201-302) 1915, III (pag. 303-461) 1918, IV (pag. 462483) 1919.

1920 - 25. Vol. II. Part I (pag. 485-652) 1920, II (pag. 653-705) 1921, III (pag. 706-856) 1923, IV (pag. 857-900) 1925. London.

1856. Die fossilen Mollusken des Tertiärbeckens von Wien. I Band. Univalven. Abhandl. d. k. k. geol. Reichsanst. III. Wien.

1870. II Band. Bivalven. Ibid. IV. Wien. 
45. Hoernes, R. et M. Auinger.

46. Jeffreys, J. G. 47. Jentsch, A.

48. Jessen, O.

49. Kautsky, F.

50. KaUtsky, F.

51. Kautsky, F.

52. Kittl, E.

53. Kittr, E.

54. $\mathrm{KocH}, \mathrm{A}$.

55. Koch, E., K. Gripp u. A. Franke.

56. Koch, E. u. K. Gripp.

57. KocH, E.

58. Koch, F. E. u. C. M. WiechMANN
1879-91. Die Gasteropoden der Meeresablagerungen der ersten und zweiten miocänen Mediterran-Stufe in der Östereichisch-Ungarischen Monarchie. pag. $1-52,1879$; p. $53-112,1880$; p. $113-152,1882$; p. 153 -192, 1884; p. 193 -232, 1885; p. 233-282, 1890 ; p. 283 - 330, 1891; p. 331-382, 1891. Wien.

1863-69. British Conchology. Vol. III, IV, V. London.

1907. Jahrbuch der Königl. Preuss. Geol. Landesanstalt für 1907. p. 883. Bohrung Xions, Bahnhofsbrunnen. Berlin.

1938. Tertiärklima und Mittelgebirgsmorphologie (Erfahrungen aus den afrikanischen Tropen). Zeitschrift d. Gesellschaft für Erdkunde zu Berlin H. $1 / 2.1938$ S. 36 . Berlin.

1925. Das Miocän von Hemmoor und Basbeck-Osten. Abhandl. d. Preuss. Geol. Landesanstalt. N. Folge Heft 97. Berlin.

1925. Die boreale und mediterrane Provinz des europäischen Miocäns und ihre Beziehungen zu den gleichalterigen Ablagerungen Amerikas. Mitteil. d. Geol. Ges. in Wien. XVIII Bd. p. 35. Wien.

1928. Die biostratigraphische Bedeutung der Pectiniden des niederösterreichischen Miocäns. Annalen des Naturhist. Mus. in Wien. Vol. 42. Wien.

1886. Ueber die miocenen Pteropoden von OesterreichUngarn. Annalen d. k. k. Naturhist. Hofmus. Bd.I p. 47. Wien.

1887. Die Miocenablagerungen des Ostrau-Karwiner Steinkohlenrevieres und deren Faunen. Annalen des k. k. Naturhist. Hofmus. Bd. II. p. 217. Wien.

1894. Die Tertiärbildungen des Beckens der siebenbürgischen Landestheile. I Theil. Paläogene Abtheilung.

1900. II Theil $\left.{ }^{1}\right)$. Neogene Abtheilung. Mitteil. a.d. Jahrbuche der Kgl. Ungar. Geol. Anstalt Bd. X (1894) et Bd. XVI (1900).

1912. Die staatlichen Tiefbohrungen XIV, XV, XVI, XVII in den Vierlanden bei Hamburg. Jahrb. d. Hamburgischen Wissenschaftlichen Anst. XXIX. 1911. 4. Beih. Mitt. a. d. Min.-Geol. Inst. Hamburg.

1920. Zur Stratigraphie des Jungtertiärs in Nordwestdeutschland. Mitt. a. d. Min.-Geol. Inst. in Hamburg. Beiheft zum Jahrbuche d. Hamburgischen Wissensch. Anst. XXXVI. Hamburg.

1927. Beiträge zur Geologie des Untergrundes von Hamburg und Umgeburg. Mitt. a. d. Min.-Geol. Staatsinst. in Hamburg. Heft. IX. Hamburg.

1872. Die Molluskenfauna des Sternbergergesteins in Mecklenburg. Arch. d. Ver. d. Freunde d. Naturgesch. in Mecklenburg. 25 Jahrg. Neubrandenburg.

1) Denne Afhandling har jeg ikke været i Stand til at fremskaffe. 
59. $\mathrm{KoCH}, \mathrm{F} . \mathrm{E}$.

60. v. Koenen, A.

61. v. Koenen, A.

62. v. KOENEN, A.

63. v. Koenen, A.

64. Koert, W.

65. Koert, W.

66. Kowalewski, K.

67. Krause, Paul Gustaf.

68. Lehmann, F.

69. v. Linstow, O.

70. Lörenthey, E. et K. Beurlen

71. Madsen, V.

72. Madsen, V., V. Nordmann 1908. og N. Hartz.

73. Madsen, V. et autres.
1878. Ueber die Classificirung der Pleurotomidae. Arch. d. Ver. d. Freunde d. Naturgesch. in Mecklenburg.

1865. Die Fauna der unter-oligocänen Tertiärschichten von Helmstädt bei Braunschweig. Zeitschr. d. deutschen geol. Gesellsch. p. 459. Berlin.

1867 - 68. Das marine Mitteloligocän Norddeutschlands und seine Molluskenfauna. Palaeontographica. 16. Kassel.

1872. Das Miocaen Nord-Deutschlands und seine Molluskenfauna. I Teil. Schriften d. Gesellsch. zur Beförderung d. gesammten Naturwiss. z. Marburg. Bd. 10. Kassel.

1882. II Teil Neues Jahrbuch f. Min. etc. Beilage Bd. II. Stuttgart.

1889-94. Das norddeutsche Unteroligocän und seine Molluskenfauna. Abh. z. geol. Spezialkarte von Preussen u. d. Thüringischen Staaten. 10. Heft. 1-7. Berlin.

1901. Zwei neue Aufschlüsse von marinem Oberoligozän im nördlichen Hannover. Jahrb. d. k. preuss. geol. Landesanst. 21. p. 187. Berlin.

1911. Geologische und paläontologische Mitteilungen über die Gasbohrung von Neuengamme. Jahrb. d. k. preuss. geol. Landesanstalt. 32. Teil I. p. 192. Berlin.

1935. W sprawie wieku i fauny formacji solnej Wieliczki. Zur Frage des Alters und der Fauna der Salzformation von Wieliczka. (Zusammenfassung). Bull. du Service Géol. de Pologne VIII Livr. 2. p. 218. Warszawa.

1933. Das Pliozän Ostpreussens und seine Beziehungen zum nordwestdeutschen und westdeutschen Pliozän. Abh. d. Preuss. Geol. Landesanstalt. Neue Folge, Heft 144. Berlin.

1892 - 93. Die Lamellibranchiaten des Miocäns von Dingden. Verh. d. naturhist. Vereins d. preuss. Rheinlande, Westfalens u. d. Reg. Bez. Osnabrück. 49. (1892) p. 198. 50 (1893). p. 273. Bonn.

1922. Die Verbreitung der tertiären und diluvialen Meere in Deutschland. Abh. d. Preuss. Geol. Landesanstalt. Neue Folge, Heft 87. Berlin.

1929. Die fossilen Dekapoden der Länder der Ungarischen Krone. Geologica Hungarica. Series Palaeontologica. Fasc. 3. Budapest.

1900. Kortbladet Bogense. Danmarks Geologiske Undersøgelse. I Række Nr. 7. København.

Eem Zonerne. Danmarks Geologiske Undersøgelse, II Række. Nr. 17. København.

1928. Aperçu de la Géologie du Danemark. Service Géol. du Danemark. $5^{\mathrm{e}}$ Série No. 4. Copenhague. 
74. Madsen, V., Hilmar Ødum og Helge Gry.

75. Martin, G. C.

76. Maryland

7\%. Meyn, L.

78. Meyn, L.

1935. Boringerne ved Langbrogaard ved Sønderborg. Danmarks Geologiske Undersøgelse. II Række. Nr. 55. København.

1904. Systematic Paleontology of the Miocene deposits of Maryland (Gastropoda, Scaphopoda). Maryland Geol. Survey. Miocene. p. 130. Baltimore.

1904. Miocene. see No. 76 .

1848. Geognostische Beobachtungen in den Herzogthümern Schleswig und Holstein. Jahresbericht d. 11 Versammlung deutscher Land- und Forstwirthe. Altona.

1851. Neue Beobachtungspunkte mitteltertiärer Schichten in Lauenburg und Holstein. Zeitschr. d. Deutsch. Geol. Gesellsch. III Bd. p. 411. (p. 431). Berlin.

79. MolengraffF, G. A. F. u. 1913. Niederlande. Handbuch der Regionalen Geologie. W. A. S. M. van Waterschoot 1.3. Heidelberg. VAN DER Gracht

80. Мørсh, O.

81. Noszky, J.

82. Nyst, P. H.

83. Nyst, P. H.

84. Nyst, P. H.

85. Nyst et Westendorph.

86. NørregaArd, E. M.

87. Nørregatrd, E. M.

88. Noetling, F.
1874. Nye Tertiærforsteninger i Danmark. Forhandlingerne ved de Skandinaviske Naturforskeres 11te Møde. p. 274. Kobenhavn.

1936. Az egri felsö Cattien molluszka faunája. — Die Molluskenfauna des oberen Cattiens von Eger. Annales Historico Naturales Musei Nationalis Hungarici, Vol XXX. Pars Mineralogica etc. p. 53. Budapest.

1845. Description des Coquilles et des Polypiers fossiles tertiaires de la Belgique. Bruxelles.

1861. Notice sur un nouveau gîte de fossiles se rapportant aux espèces faluniennes du midi de l'Europe, découvert a Edeghem près d'Anvers. Bull. de l'Acad. Roy. des Sciences etc. de Belgique Vol. XII, T. 7, p. 29. Bruxelles.

1881. Conchyliologie des terraines tertiaires de la Belgique. I Partie Terrain Pliocène Scaldisien. Ann. du Mus. Roy. d'Hist de Belgique, Ser. Paléontologique V. III Bruxelles.

1839. Nouvelles recherches sur les coquilles fossiles de la province d'Anvers. Bull. de l'Acad. Royale des sciences etc. de Belgique. T. VI. Bruxelles.

1916. Mellem-miocæne Blokke fra Esbjerg. Résumé en français. Danmarks Geologiske Undersøgelse. IV Række. Bd. 1, Nr. 5. København.

1926. En Blok med Bulla cfr. subampulla D'OrB. fra Flensborg Fjord. Meddelelser fra Dansk Geologisk Forening. Bd. VII, p, 83. København.

1885. Die Fauna des samländischen Tertiärs. I Theil (Vertebrata, Crustacea u.Vermes, Echinodermata.)

1888. II Theil. (Gastropoda, Pelecypoda, Bryozoa etc.) Abh. zur geologischen Specialkarte v. Preussen u. d. Thür. Staaten. Bd. VI, Heft 3-4. Berlin. 


\author{
89. Oppenheim, P. \\ 90. D'Orbigny, A. \\ 91. Реyrot. \\ 92. Philippi, R. A. \\ 93. Quitzow, W.
}

94. Ravn, J. P. J.

95. RavN, J. P. J.

96. Ravn, J. P. J.

97. Sacco, F.

98. SARS, G. O.

99. Sandberger, C. L. F.

100. Schaffer, F. X.

101. Schaffer F. X.

102. Schaffer, F. X.

103. Schaffer, F. X.

104. Schenk, Hubert G.

105. Segerberg, K. O.

106. Semper, J. O.
136

1916. Über das marine Miocän im Nordseebecken. Centralblatt f. Mineralogie etc. p. 396. Stuttgart.

1852. Prodrome de Paléontologie stratigraphique universelle des animaux mollusque et rayonnés Vol. III. Paris.

1925-34. Se under Cossmann.

1844. Enummeratio Molluscorum Siciliae. Vol. II. Halis Saxonum.

1922. Die Fauna des marinen Miocäns von Alt-Gleiwitz. Ein Beitrag zur Altersfrage des oberschlesischen Tertiärs. Jahrb. d. Preuss. Geol. Landesanst. Bd. VLI. Teil II. Heft 1, p. 1. Berlin.

1903. The Tertiary Fauna at Kap Dalton in East Greenland. Meddelelser om Grønland Vol. XXIX; p. 93. København.

1907. Molluskfaunaen i Jyllands Tertiæraflejringer. Résumé en français. Det Kgl. Danske Vidensk. Selsk. Skrifter, 7 Række, naturvidensk. og matem. Afd. III. 2. p. 217. København.

1933. New Investigations of the Tertiary at Cape Dalton East Greenland. Meddelelser om Grønland. Bd. 105, Nr. 1. København.

1890-1904. I Molluschi etc. se under Bellardi.

1878. Mollusca Regionis Arcticae Norvegiae. Christiania.

1863. Die Conchylien des Mainzer Tertiärbeckens. Wiesbaden.

1910. Das Miocän von Eggenburg. Die Fauna der I Mediterranstufe des Wiener Beckens. Heft 1 (Bivalven), Heft 2. (Gastropoden). Abhandl. d. k. k. geol. Reichanstalt, Bd. XXII. Wien.

1910. Zur Kenntnis der Miocänbildungen von Eggenburg (Nieder-Österreich) I. Die Bivalvenfauna von Eggenburg. Sitzungsbereicht d. kais. Akademie d. Wissenschaften. Bd. 119, p. 249. Math. naturwissensch. Kl. Abt. I. Wien.

1912. II Die Gastropodenfauna von Eggenburg. Ibid. Bd. 121. Mat. nat. Kl. Abt. I. Wien.

1927. Der Begriff der "miocänen Mediterranstufen" ist zu streichen. Verhandl. d. Geol. Bundesanstalt p. 86. Wien 1927.

1936. Neuere Wiener Tertiärliteratur. Verhandl. d. Geol. Bundesanstalt p. 243. Wien 1936.

1935. Neotypes of Nucula nucleus (Linné). - Proceedings of the Malac. Soc. Vol. XXI; Part IV. p. 258. London.

1900. De anomura och brachyura dekapoderna inom Skandinaviens yngre krita. Geol. Föreningen i Stockholm Förhandlingar. Bd. 22. p. 347. Stockholm.

1861. Paläontologische Untersuchungen. Neubrandenburg. 
10\%. Sindowski, K. H.

108. Sorgenfrei, Theodor.

109. Sorgenfrei, Theodor.

110. Speyer, O,

111. Speyer, O.

112. Speyer, O.

113. Speyer, O. u.

A. v. KoEnen

114. Staesche, Karl.

115. Staesche, Karl.

116. Staesche, Karl.

11\%. Stainier, $\mathrm{X}$.

118. Stolley, E.

119. v. Telegd, Karl Roth

120. Thorson, Gunnar

121. Vaughan, Thomas WaYland

122. WARNECK, W.
1936. Faziesprobleme der mitteleuropäischen Tertiärmeere. Nr. 1. Pommersches Mitteloligocän. Zentralblatt f. Min. etc. Abt. B. p. 369-77. Stuttgart.

1937. Some Remarks on the Hinge of Nuculids and Ledids. Vidensk. Meddelelser fra Dansk naturhist. Foren. Bd. 100, p. 370. København.

1939. Faunaen i tertiære Blokke fra FlensborgfjordOmraadet (Foredragsreferat). Meddelelser fra Dansk Geol. Forening Bd. 9, Hefte 4 p. 530. København.

1864. Die Tertiär-Fauna von Söllingen bei Jerxheim im Herzogthum Braunschweig. Palaeontographica. IX, p. 247. Cassel.

1866. Die Ober-oligocänen Tertiärgebilde und deren Fauna im Fürstenthum Lippe-Detmold. Palaeontographica XVI p. $1-52$. Cassel.

1870. Die Conchylien der Casseler Tertiärbildungen. Palaeontographica. IX, XVI, XIX. Cassel.

1884. Die Bivalven der Casseler Tertiär Bildungen. Abh. z. geol. Spezialk. v. Preussen etc. Bd. IV, Heft 4. Berlin.

1930. Zur Gliederung des obermiozänen Glimmertons. Jahrb. d. Preuss. Geol. Landesanst. Bd. 51. p. 55. Berlin.

1936. Die Fauna des Unterereozäns von Friedland in Mecklenburg. Mitt. a. d. Mecklenb. Geol. Landesanstalt. Heft 43, Neue Folge 8. Rostock.

1937. Die Gliederung des nordwestdeutschen Tertiärs auf Grund von Mikrofossilien. Jahrb. d. Preuss. Geol. Landesanst. Bd. 58. p. 730. Berlin.

1886. Coeloma rupeliense, Brachyure nouveau de I'argile rupélienne. Ann. d. la société géol. de Belgique. Vol.. 14, p. 86. 1886-87.

1890. Ueber zwei Brachyuren aus dem mitteloligocaenen Septarienthon Norddeutschlands. Mitteil a. d. mineral. Inst. d. Universität Kiel. Bd. 1., Heft 3, p. 151.

1914. Eine oberoligozäne Fauna aus Ungarn. Geologica Hungarica. Tomus I; Fasc. I. Budapest.

1936. The Larval Development, Growth, and Metabolism of Arctic Marine Bottom Invertebrates Compared with those of other Seas. Meddelelser om Grønland Bd.100. København.

1924. Criteria and Status of Correlation and Classification of Tertiary Deposits. Bull. of the Geol. Soc. of America. Vol. 35, p. 677. Washington.

1926. Das Tertiär von Jatznick i. Pom. und seine stratigraphische Stellung in Norddeutschland. Abh. d. Preuss. Geol. Landesanstalt. Neue Folge Heft. 101. Berlin. 
123. WeinkaufF, H. C.

124. WeYL, R.

125. WIRTZ, D.

126. WolfF. W.

127. Wood, S.

128. WoODring, W. P.

129. WOODRING, W. P.

130. Ødum, Hilmar.

131. Ødum, Hilmar.

132. Ødum, Hilmar.
1867. Die Conchylien des Mittelmeeres Bd. I. Mollusca. acephala.

1868. Bd. II. Mollusca cephala. Kassel.

1936. Faziesprobleme der mitteleuropäischen Tertiärmeere Nr. 2. Fazies und Fauna im Untermiocän Schleswig-Holsteins. Zentralblatt f. Min. etc. Abt. B; p. 377-394. Stuttgart.

1933. Über Anhäufungen loser Miozänfossilien in jungdiluvialen Schmelzwassersanden Schleswig-Holsteins. Zeitschr. f. Geschiebeforschung. Bd. IX. Heft. 1, p. 7.

1910. Eine merkwürdige Miocänfauna von Ibbenbüren (Westfalen). Monatsbericht d. Deutsch. Geol. Ges. Bd. 62, p. 202.

1848 - 82. A Monograph of the Crag Mollusca. Vol. I-II + Suppl. The Palæontographical Society. London.

1924. Tertiary History of the North Atlantic Ocean. Bull. of the Geol. Soc. of America. Vol. 35, No. 3, p. 425. Washington.

1924. West Indian, Central American and European Miocene and Pliocene Mollusks. Bull. of the Geol. Soc. of America. Vol. 35, No. 4, p. 857. Washington.

1933. Mindre Meddelelser fra D. G. U's Borearkiv Nr. 11. Den prækvartære Undergrund ved Sønderborg. Meddelelser fra Dansk Geol. Forening. Bd. 8, p. 262. København.

1934. En Forekomst af marint Pliocæn ved Tønder. Mit deutscher Zusammenfassung. Medd. fra Dansk Geol. Foren. Bd. 8, p. 359. København.

1935. Se under V. Madsen. 


\section{Register $\left.{ }^{1}\right)$.}

\begin{tabular}{|c|c|}
\hline 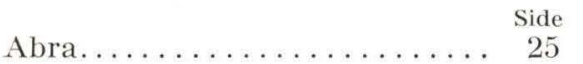 & Bathytoma \\
\hline angulosa........... 25, 99 & $\begin{array}{c}\text { Batnytoma } \\
- \text { cataphracta........... }\end{array}$ \\
\hline - marylandica.......... 25, 99 & — cataphracta var. humilis ... 54 \\
\hline prismatica........ 25, 99 & - turbida........... 55, 111 \\
\hline$\ldots \ldots \ldots \ldots$ & Bittlum \\
\hline$\ldots \ldots \ldots \ldots$ & $\ldots 35,11$ \\
\hline$\ldots \ldots 59,113$ & 36,11 \\
\hline dalum........ 38 & $.35,16$ \\
\hline 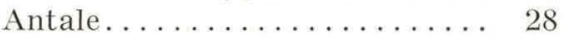 & \\
\hline$\ldots \ldots 28$ & \\
\hline$\ldots \ldots \ldots \ldots \ldots 37$ & \\
\hline$\ldots \ldots \ldots \ldots$ & $\ldots \ldots \ldots \ldots$ \\
\hline$\ldots \ldots \ldots$ & 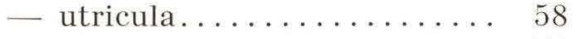 \\
\hline $1 a \ldots \ldots$ & \\
\hline$\ldots \ldots \ldots \ldots \ldots$ & 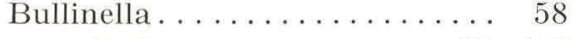 \\
\hline$\ldots \ldots \ldots \ldots 47,109$ & $\ldots \ldots \ldots$ \\
\hline$\ldots \ldots \ldots \ldots 46,108$ & $\ldots \ldots \ldots \ldots 58,11$ \\
\hline$\ldots \ldots \ldots \ldots \ldots, \quad 1$ & \\
\hline$\ldots \ldots \ldots \ldots 18,96$ & \\
\hline$\ldots \ldots \ldots \ldots \ldots$ & 47 \\
\hline$\ldots \ldots \ldots \ldots \ldots \ldots, 1$ & . \\
\hline$\ldots \ldots \ldots 14,9$ & $\ldots \ldots \ldots \ldots$ \\
\hline $\operatorname{lum} \ldots \ldots \ldots \ldots$ & $\ldots \ldots \ldots$ \\
\hline$\ldots \ldots \ldots \ldots \ldots$ & $\ldots \ldots \ldots 27,100$ \\
\hline$\ldots \ldots \ldots 20$ & $\ldots \ldots . . .$. \\
\hline acilis $\ldots .$. & ........ \\
\hline$\ldots \ldots \ldots \ldots$ & $1 \ldots \ldots \ldots \ldots 21$ \\
\hline$\ldots \ldots \ldots \ldots \ldots 21,97$ & — cyprium... \\
\hline $\begin{array}{ll}\cdots \ldots \ldots \ldots \ldots & 20\end{array}$ & $-f$ \\
\hline$\ldots \ldots \ldots \ldots$ & -1 \\
\hline , 1 & 21, \\
\hline s utriculus. . . . . . . . . 59 & - turoidum \\
\hline & \\
\hline
\end{tabular}

1) Synonymerne, Familie- og Genusnavne er trykt med almindelig Skrift, Artsnavne med Kursiv; de kursiverede Sidetal henviser til den tyske Tekst.

Die Synonymen und die Namen der Familien und Genera sind mit der Grundschrift, die Artsnamen mit Kursiv gedruckt; die kursivierten Seitenzahlen beziehen sich auf den deutschen Text. 
Cassidea . ............. $\begin{array}{r}\text { Side } \\ 39\end{array}$

- megapolitana ........... 40

- Rondeletii.......... 39, 106

Cassididae .............. 39

Cassis elongata........... 40

- Hertha .............. 40

- Sandbergeri............ 40

- subventricosa .......... 39

Catametopa.............. 61

Cavolinidae .............. 60

Cerithidae ............. 35

Cerithium Genei ........36, 105

Chenopus............... 37

— speciosus ......... 37, 105

— - var. Margerini...... 38, 105

— - megapolitana ....... 38

Clinura trochlearis.......... 49

Coeloma................ 61

- bicarinatum ......6.61, 64, 116

- holsaticum...... 63, 64, 116

- incarinatum.........6.61, 114

- rupeliense..........64, 116

Columbella fallax........... 44

- subulata............. 44

Columbellidae ............ 44

Conidae ............... 48

Conus ............... 48

- Allionii ............48, 109

- Semperi........... 48, 109

Corbula costellata ......... 27

— Waeli ................ 27

Cordiopsis ............... 22

- incrassata..........22, 98

Crustacea...........61, 114

Cuspidaria ............. 27

- costellata..........27, 100

Cuspidariidae............ 27

Cylichna cylindracea........ 58

- Seebachii ............. 58

Cymatosyrinx ........... 55

- Selenkae.......... 55, 111

Cypraea ............... 38

— amygdalum ......... 38, 106

— subamygdalum ......... 38

Cypraeidae.............. 38

Cyprina............. 23, 98

Cyprinidae.............. 23

Daphnella ............... 56

— mio Roemeri........... 56

- Roemeri........... 56, 111

Dentaliidae ............. $\quad \begin{array}{r}\text { Side } \\ 28\end{array}$

Dentalium ................ 28

- badense............29, 101

— badensis var. borealis... 29, 101

- caduloide........... 29, 101

— Dollfusi ............. 29, 101

— entale........... 28, 101

— entalis.............. 28

- mutabile .............. 29

- vitreum..........28, 101

Dolicholathyrus ........... 45

- Rothi.............45, 108

Dolichotoma subdenticulata ... 54

- turbida............. 54

Doliidae ................ 39

Drillia................... 55

- Koeneni .............. 55

- limatula var. pyramidalis 56, 111

- Selenkae............ 55, 111

— Suessii ............. 55

Entalis ................. 29

— badense............29, 101

Eulima................. 34

- flexuosa........... 34, 104

- subula............ 34, 104

Eulimidae ............. 34

Ficula simplex ........... 39

Fusus crispoides........... 45

- crispus..........44, 108

— fasciolaroides........... 46

- pereger............ 47

- Rothi ................ 45

— sexcostatus ........... 46

Fusidae................. 45

Gastropoda........... 30, 102

Genotia................. 49

- trochlearis......... 49, 109

Haustellum . . . . . . . . . . . . 41

— inornatus ............. 41

- paucispinatus........41, 106

Hemipleurotoma ........... 53

- Duchastelii.......... 53, 111

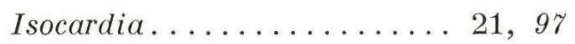

Isocardiidae............ 21 
Jupiteria . . . . . . . . . . 17

- pygmaea............ 17

Laevicardium . . . . . . . . . . . . 21

- cyprium ............. 21

- leptocolpatum ........... 21

- subturgidum. . . . . . . . 21, 97

Latirus Fornicatus.......... 45

Lamellibranchiata . . . . . . . . 14, 93

Leda... . . . . . . . . . . . . . 17

- glaberrima............ 18

- pygmaea........................... 17

Ledidae . . . . . . . . . . . . . . 17

Leptoconus . . . . . . . . . . . . . . 48 Allionii...........44, 109

Ligula donaciformis . . . . . . . . 25

Limopsidae . . . . . . . . . . . . 19

Limopsis . . . . . . . . . . . . . . 19

- aurita............ 19, 96

— - var. parva .......... 19

- - minuta ......... 19

— Goldfussi ............ 19

Limacinidae . . . . . . . . . . . . . . 59

Lissochlamys . . . . . . . . . . . . . 14

— cfr. Gérardi .......... 14, 93

Lunatia . . . . . . . . . . . . . . . . 32

- helicina........... 32, 103

Macrurella .............. 44

- subulata...........44, $10 \%$

Mangelia Roemeri ......... 56

Meretrix................. 22

— incrassata........... 22, 98

— - var. flexicostulata ...... 22

Modiola sericea............. 14

Murex.................. 41

- capito.............. 42

- Deshayesii......... 42, 107

- horridus ............. 43

- inornatus......... 42, $10 \%$

— - var. spinifera...... .41, 107

- Partschi............ 42, 106

- paucispinatus........41, 106

- Sismondae ............. 41

- spinicosta......... 42, 106

Muricantha ............... 42

— Deshayesii......... 42, 107

Muricidae ............... 41

Mytilidae . . . . . . . . . . . . . 14

Mytilus sericeus ........... 14
Side

Narona varicosa........... 47

Nassa . . . . . . . . . . . . . . . 44

— Neuvillei ... . . . . . . . . 45, 108

- Schlotheimi......... 44, 108

- Schroederi.......... . 45, 108

Nassidae... . . . . . . . . . . . . . 44

Natica.................. . 32

- catena............ 33, 103

— - var. cyclostomoides. . 33, 103

— - - helicina.......... 32

_ hantoniensis ......... 33, 103

- helicina............ . 32, 103

— Josephinia.......... . . 33, 103

- Nysti. . . . . . . . . . . 32, 103

— submammillaris...... . 33, 103

Naticidae............... 32

Neaera costellata.......... 27

Neverita Josephinia. . . . . . . . . 33

Newtoniella ............... 36

- cyrtogyra.......... 36, 105

_ trilineata .......... 37, 105

Nucula ... . . . . . . . . . . . . 15

- Benoisti........... 17, 95

- glaberrima............. 18

- hanseata............. 15, 94

— nucleus.............16,95

- nucleus var. Hanleyi.... 17, 95

- Philippiana.......... 17, 95

- proxima........... 17, 95

- tenuis............ 17, 95

Nuculana glaberrima........ 18

Nuculidae.............. 15

Ophistobranchiata ........ 57

Panopaea................ 26

- Ménardi............ 26, 100

- Whitfieldi..........26, 100

Panopaeidae ............. 26

Pecten............... 14, 93

Pectinidae .............. 14

Pleurotoma ............. 51

- Badensis............... 52

- Calliope ............... 49

- cataphracta............ 54

- coronata var. lapugyensis... 51

— - var. trifasciata........ 53

Pleurotoma Duchastelii.... . 53, 111

— - var. flexiplicata....... 53

- - multilineata .... 54, 111 
Pleurotoma Duchastelli ....... 53

— flexiplicata........... 53

- Geinitzi........ 52, 53, 111

— Koeneni.............. 55

- multicostata .......... 53

- rotata............51, 110

— - var. peyrerensis....... 51

— - var. pluridenticula ..... 51

- - var. subrotata........ 51

— Selenkae.............. 55

- Steinvorthi............. 50

— subdenticulata........ . 53, 54

- Suessii............... 55

- trifasciata....... 52, 53, 110

- trochlearis ............ 49

— turbida ............. 54

Pleurotomidae............ 50

Polinices................. 33

- submammillaris....... 33, 103

Portlandia pygmaea ........ 17

Prosobranchia.......... 30, 102

Pseudolathyrus............ 45

- Rothi............ 45, 108

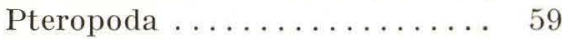

Pyramidella.............. 33

- conulus........... 34, 103

- laeviscula. . . . . . . . . . . 33

- plicosa............ 33, 103

Pyramidellidae ........... 33

Pyrula ................... 39

— Harrisi............ . 39, 106

- simplex.......... 39, 106

Raphitoma............. 56

- mio Roemeri........... 56

- Roemeri........... 56, 112

Ringicula............ . 57, 112

Ringiculidae ............ 57

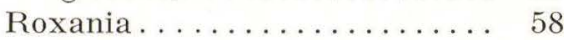

- Clara ............... 59

- utriculus.............. 58

Roxanias utriculus......... 59

Scaphander .............. 57

- lignarius var. Grateloupi 57, 112

Scaphandridae........... 57

Scaphopoda........... . 28, 101

Scrobiculariidae .......... 25

Seila . . . . . . . . . . . . 36

- cyrtogyra..........36, 105

— trilineata ......... 37, 105
Side

Semicassis ............... 39

- megapolitana ........... 40

- Rondeletii.......... 39, 106

Simpulum enode........ 41, 106

Solariidae ............... . 31

Solarium. . . . . . . . . . . . . . 31

— Dumontii.......... 31, 102

Spirialis ............... 59

- dilatata............ 60, 113

— stenomphalus........ 59, 113

Streptochetus ............ 46

- sexcostatus.......... 46, 108

Surcula ................. 50

- regularis............ 50, 110

- Steinvorthi......... . 50, 110

Sveltia ................ 47

- varicosa.......... 47, 109

— - var. paucicostatata . . 48, 109

— — bearnensis .... . 48, 109

— — - simplicior...... 48, 109

Syndosmya angulosa........ 25

- stricta............. 25

Telasco................. 44

— Neuvillei.......... . 45, 108

- Schlotheimi......... 44, 108

Tellina ............... 23

— Benedenii.......... 24, 98

- decipiens ............ 24, 99

- fallax............ 23, 98

Tellinidae.............. 23

Testrastomella subulata . . . . . 44

Thracia................ 26

- Conradi.......... 27, 100

- convexa ............. 27

— ficiformis ............ 27

- ventricosa.......... 26, 100

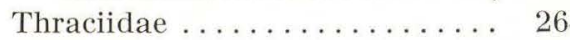

Tiphys ................ 43

- horridus.......... 43, $10 \%$

Tiphys pungens........ 43, $10 \%$

Tritoniidae............. 41

Tritonium .............. 41

- enode...........44, 106

- flandricum..........44, 106

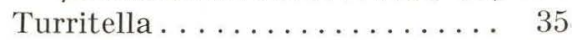

- Geinitzi............ 35, 104

- Sandbergeri. . . . . . . . . 35, 104

Turritellidae ............ 35

Typhis $=$ Tiphys. 
Vaginella .............. $\quad 60$

Side

- depressa ............ 60

Vaginella depressa var. austriaca 60

Veneridae............... 22

Voluta varicosa .......... 47

Yoldia................. 18

- glaberrima........... 18, 95

- laevis ............. 18, 95

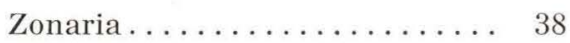

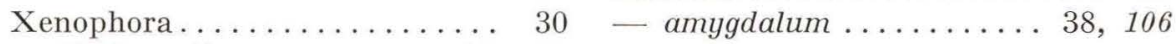

- Deshayesii......... 30, 102 — fabagina var. amygdalum... 38 
Tavle I. 

Tavle II. 
Fig. 1. Klintinghoved set fra Øst. I Baggrunden Vemmingbund.

» 2. Klintinghoved. Klintprofilet ud for Punkt 50 (se Tavle I). M.l.= Moræneler, Gl.1.= Glimmerler, Gl.s.=Glimmersand, s.Gl.l. $=$ sandet Glimmerler. 


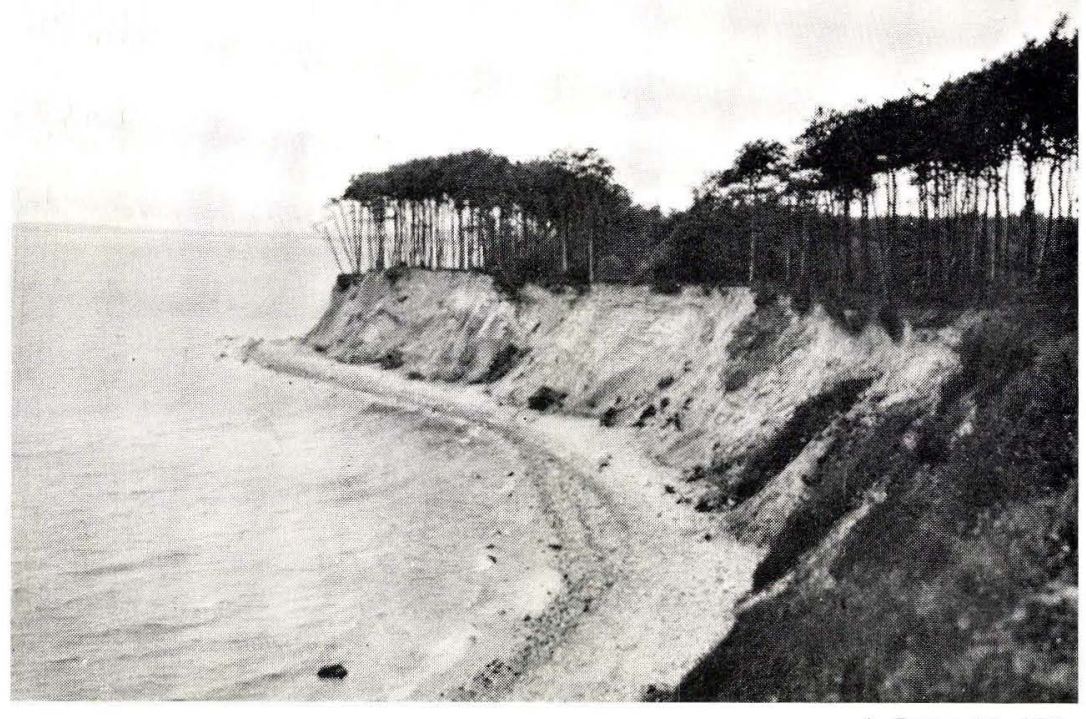

Fig. 1.

A. Jessen fot. 1929

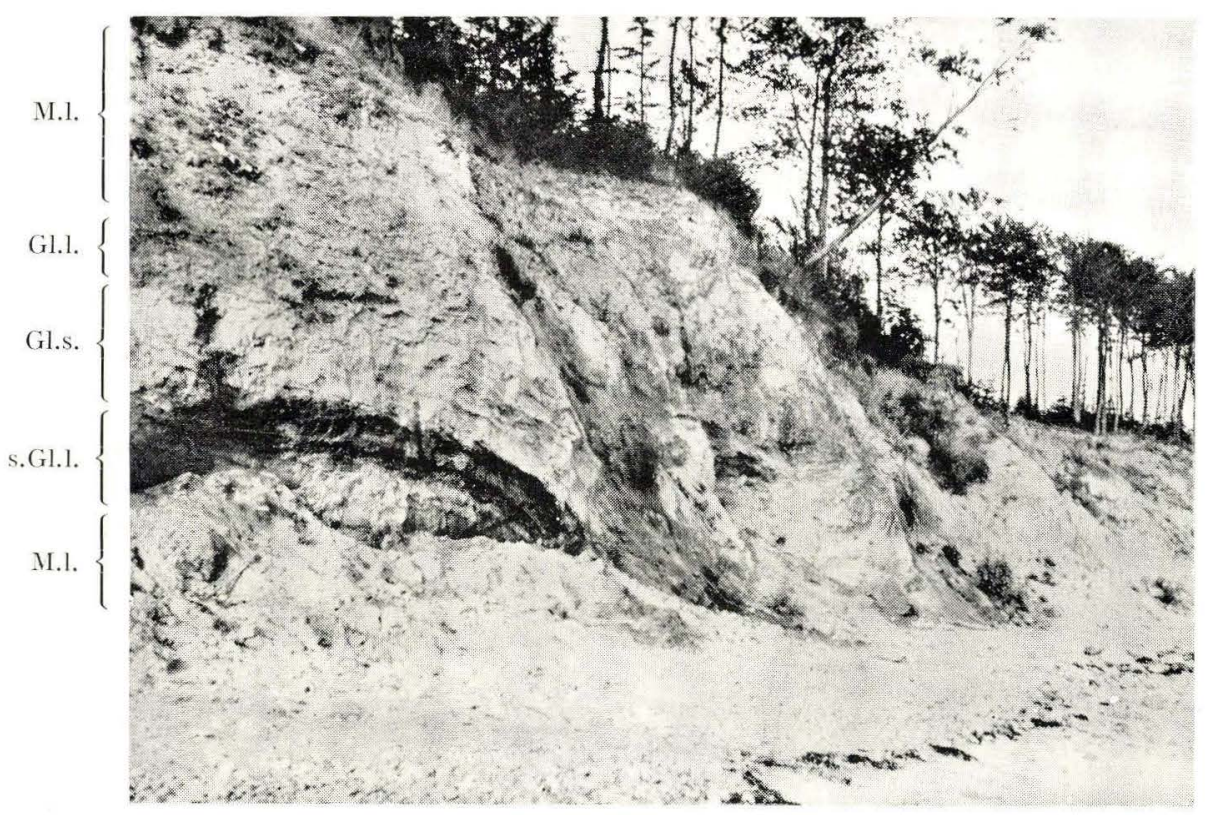

Fig. 2.

A. Jessen fot. 1937. 
Tavle III. 
Detailprofil ca. ud for Punkt 85 (se Tavle I). Siden Profilet opmaaltes i 1935 er der paa dette Sted skredet store Masser ud, hvilket forklarer Forskellen sammenlignet med Profilskitsen Tavle I.

Dil.s. = Diluvialsand, Gl.l. = Glimmerler, Gl.s. = Glimmersand, M.l. = Moræneler. 


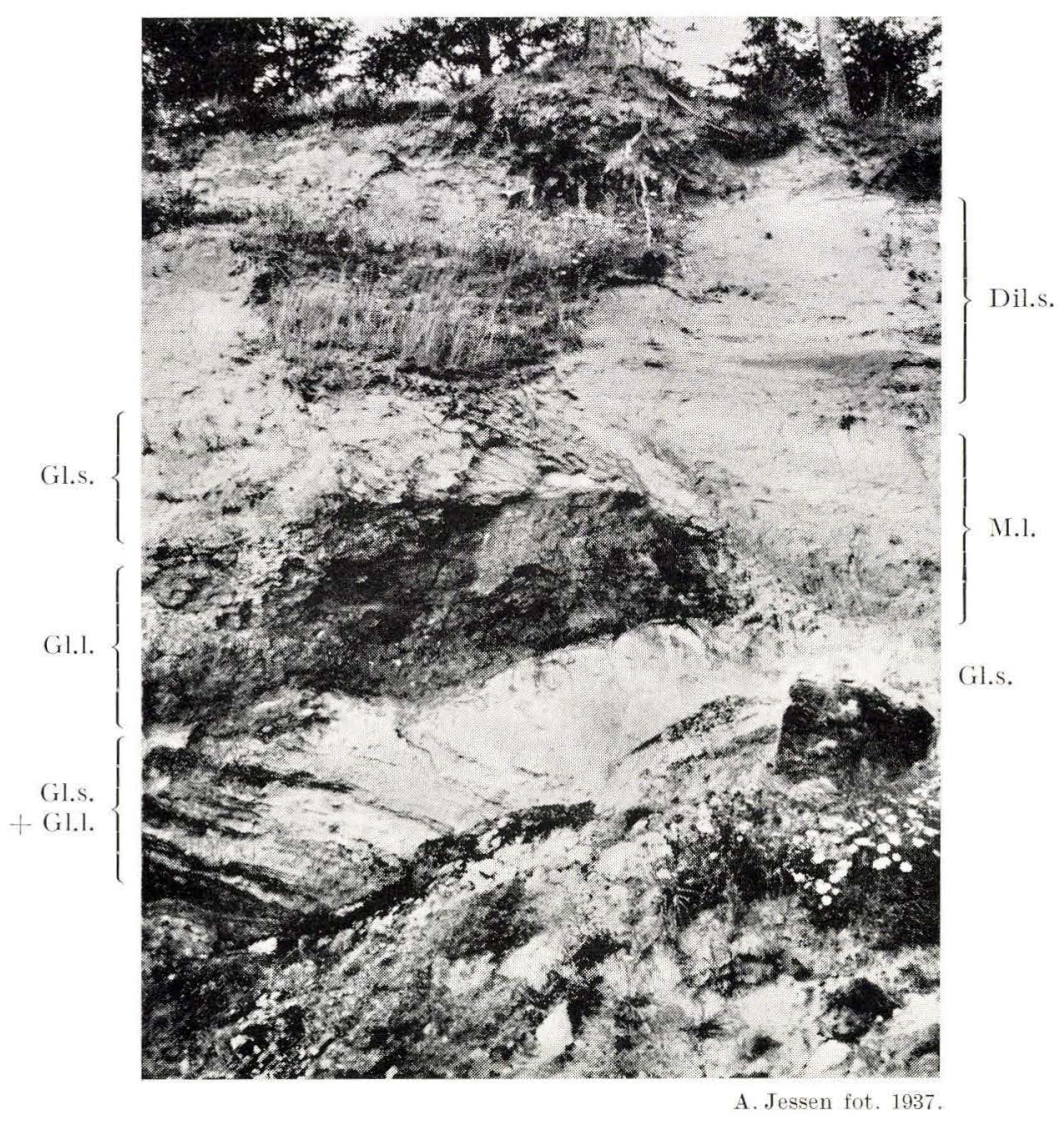


Tavle IV. 
Fig. 1. Lissochlamys cfr. Gérardi Nyst, Højreskal, 2/1; pag. 14 (93).

2. Nucula hanseata Kautsky, Højreskal, $1 / 1$; pag. 15 (94).

"3. " " " " indvendig, ${ }^{1} / 1$. Nr. 1 - 9 Fodmuskelaftryk.

"4. Yoldia glaberrima Münster, Venstreskal, 1/1; pag. 18 (95).

" 5. Limopsis aurita Brocchi, Højreskal, 1/1; pag. 19 (96).

"6. " " " " indvendig, $2 / 1$.

" 7. Cardium (Laevicardium) subturgidum D'Orbigny, Venstreskal, 1/1; pag. 21 (97).

" 8. Astarte concentrica Goldfuss, Venstreskal, 2/1; pag. 20 (97).

" 9. Meretrix incrassata Sow. var. flexicostulata KAutsky, Hængselparti af en Højre-

10. " " " " " KAutsky, Højreskal, 1/1.

" 11. Tellina fallax Beyrich, Venstreskal, 1/1; pag. 23 (98).

"12. " " $"$ Højreskal, indvendig, ${ }^{1}$.

"13. Abra angulosa Renieri, Højreskal, 2/1; pag. 25 (99).

"14. " " defekt Højreskal indvendig, $1 / 1$.

»15. Panopaea Ménardi Deshayes, Venstreskal, 1/1; pag. 26 (100).

" 16. Thracia ventricosa Philippi, Hojreskal, 1/1; pag. 26 (100).

" 17. Cuspidaria (Cardiomya) costellata Deshayes, Venstreskal, 2/1 ; pag. 27 (100).

De i Parentes anførte Sidetal henviser til det tyske Résumé.

Die in Klammern angeführten Seitenzahlen beziehen sich auf die deutsche Zusammenfassung. 


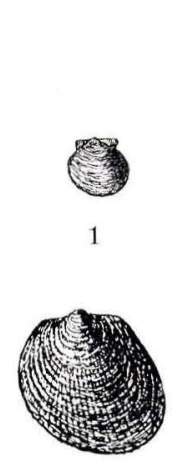

5

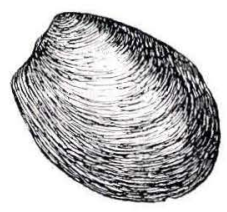

2

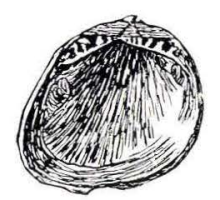

6

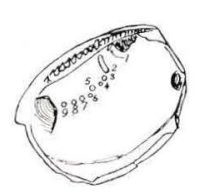

3

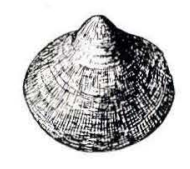

7

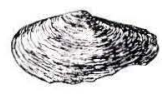

4

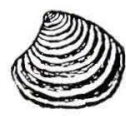

8
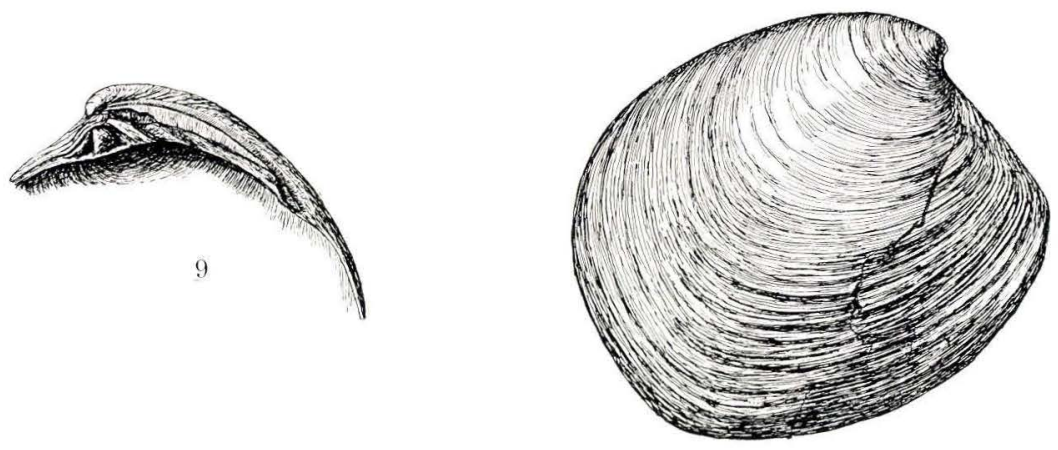

10

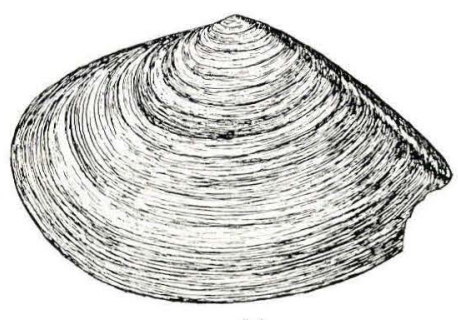

11

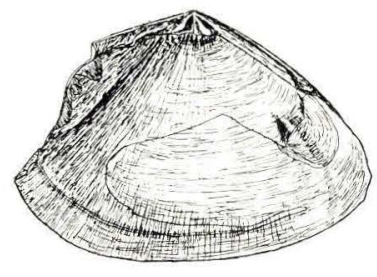

12

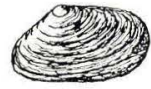

13

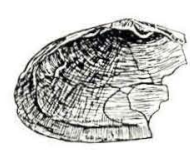

14
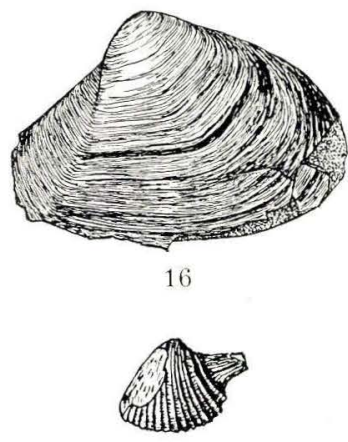

17

Theodor sorgenfrei del. 15 
Tavle V. 
Fig. 1. Xenophora Deshayesii Michelottr, 1/1; pag. 30 (102).

"2. " " " Underside, $1 / 1$.

1) 3. Solarium Dumontii Nyst, Overside, $2 / 1$; pag. 31 (102).

" 4 . " " , set fra Siden, $2 / 1$.

"5. " " , Underside, $2 / 1$.

》) 6. Natica (Lunatia) helicina Brocchi, 1/1; pag. 32 (103).

" 7. Turritella Geinitzi Speyer, Mellemvindinger, 1/1; pag. 35 (104).

" $8 . "$ " " de forste Mellemvindinger, $2 / 1$.

" $9 . \quad "$ " " " sidste ", $1 / 1$.

D 10. Bittium convexorude SAcco, 1/1; pag. 35 (104).

"11. Newtoniella (Seila) cyrtogyra Cossmann et Peyrot, $2 / 1$; pag. 36 (105).

"12. Chenopus speciosus Schlotheim var. Margerini De Koninck, 1/1; pag. 37 (105).

" 13. Cypraea (Zonaria) amygdalum Brocchi, $1 / 1$; pag. 38 (106).

" 14. Pyrula simplex Beyrich, 1/1; pag. 39 (106).

" 15. Cassidea (Semicassis) Rondeletii Basterot, 1/1; beskadiget Kanal; pag. 39 (106).

"16. Tritonium (Simnulum) enode Beyrich. 1/,: Dag. 41 (106).

"17. Murex (Haustellum) paucispinatus Roth v. Telegd, 1/1; pag. 41 (106).

De i Parentes anførte Sidetal henviser til det tyske Résumé.

Die in Klammern angeführten Seitenzahlen beziehen sich auf die deutsche Zusammenfassung. 
D. G. U. II. R. Nr. 65.

\author{
Tavle V.
}
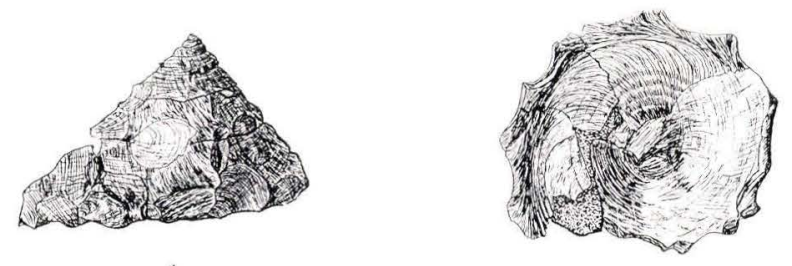

2

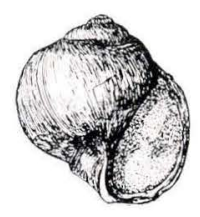

6

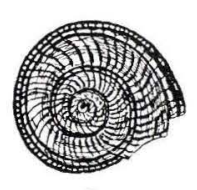

3

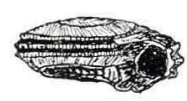

4
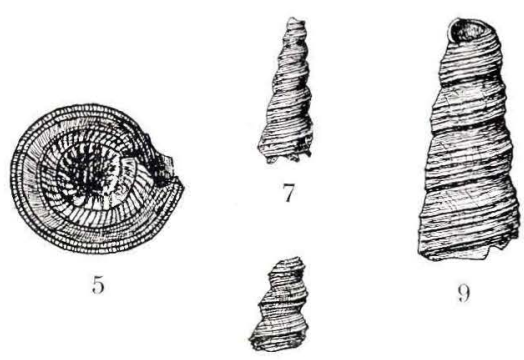

9

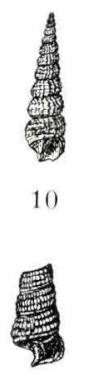

11

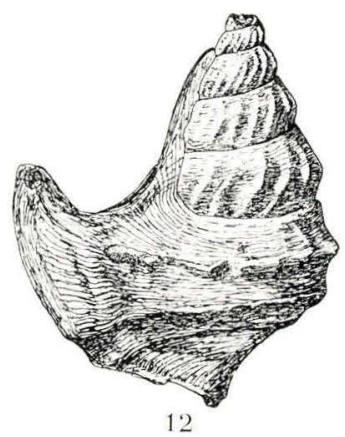

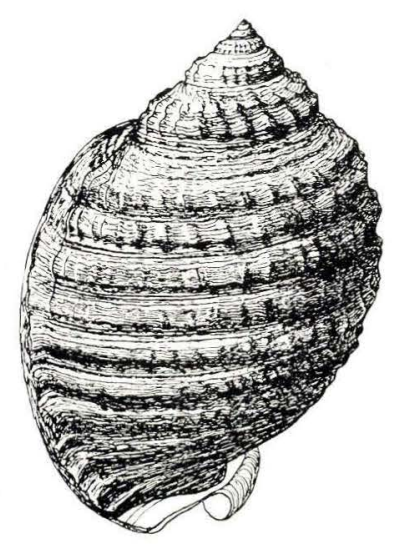

15

Theodor Sorgentrei del.

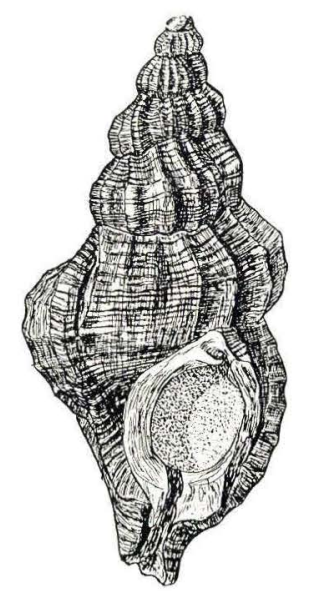

16

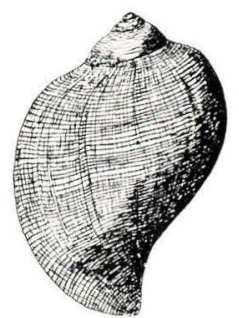

14

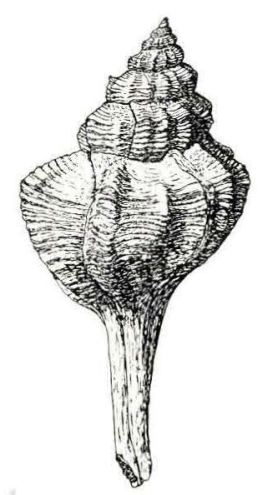

17 
Tavle VI. 
Fig. 1. Murex (Muricantha) Deshayesii Nyst, 1/1; pag. 42 (107).

" 2. Tiphys horridus Brocchr, Slutningsvinding med Munding, 1/1; pag. 43 (107).

"3. " " " samme Exemplar fra den modsatte Side.

"4. Atilia (Macrurella) subulata BrocGHI, $2 / 1$; pag. 44 (107).

5. " " " " med bevaret Embryonalskal, 2/1.

6. Nassa (Telasco) Schlotheimi Brocchi, 2/1; pag. 44 (108).

7. Dolicholathyrus (Pseudolathyrus) Rothi Beyrich, 1/1; pag. 45 (108).

8. Aquilofusus pereger Beyrich, 1/1; pag. 47 (109).

9. Sveltia varicosa Brocchi, $3 / 2$; pag. 47 (109).

10. Conus (Leptoconus) Allionii Michelottr, med lavt Spir, 1/1; pag. 48 (109).

11. " " " " hojt ", $1 / 1$.

12. Genotia trochlearis Hoennes, $1 / 1$; pag. 49 (109).

13. Surcula Steinvorthi Semper, 1/1; pag. 50 (110).

14. Pleurotoma rotata Brocchi, $1 / 1$; pag. 51 (110).

15. " (Hemipleurotoma) Duchastelii Nyst, 1/1; pag. 53 (111).

16. Bathytoma cataphracta Brocchi, 1/1; pag. 54 (111).

"17. Drillia (Cymatosyrinx) Selenkae v. Koenen, 1/1; pag. 55 (111).

" 18. Daphnella (Raphitoma) Roemeri Philippi sp., 2/1; pag. 56 (112).

" 19. Scaphander lignarius L. var. Grateloupi Michelottr, 1/1; pag. 57 (112).

20. Bullinella cylindracea Penn., $2 / 1$; pag. 58 (112).

21. "Seebachii v. Koenen, $2 / 1$; pag. 58 (113).

De i Parentes anførte Sidetal henviser til det tyske Résumé.

Die in Klammern angeführten Seitenzahlen beziehen sich auf die deutsche Zusammenfassung. 
D. G. U. II. R. Nr. 65.

Tavle VI.
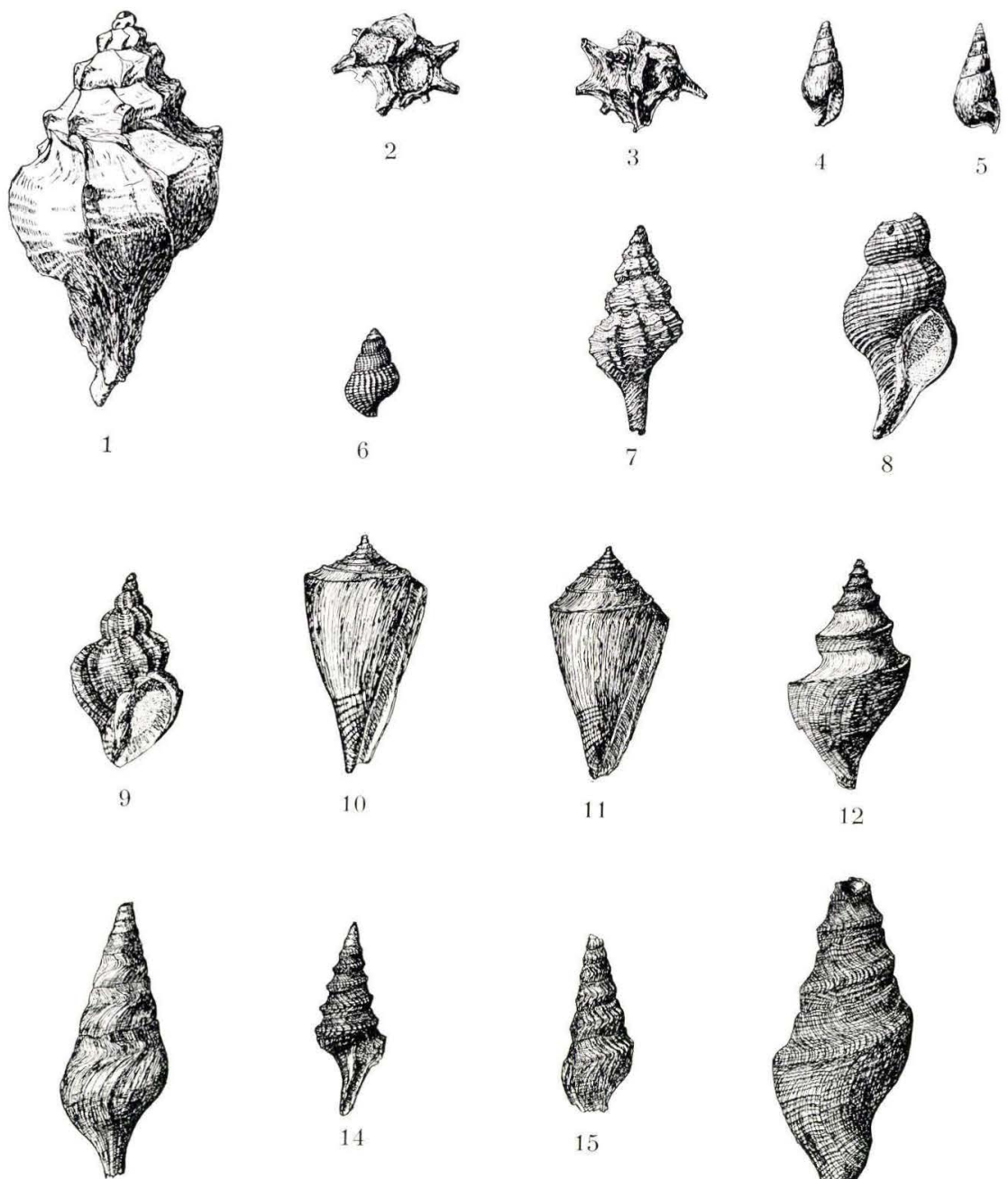

13
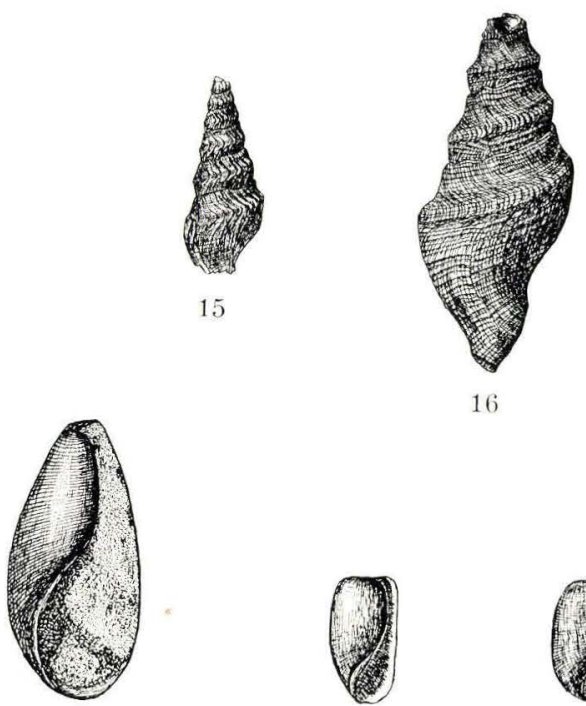

16
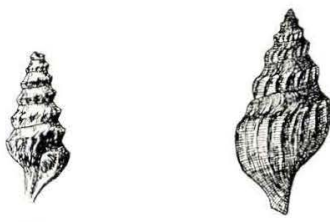

17

19
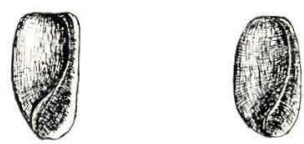

Theodor Sorgenfrei del. 
Tavle VII. 
Fig. 1. Coeloma incarinatum nov. sp. Lobernes Fordeling paa Cephalothorax, hanligt Individ.

Fig. $2-3$ fra Klintinghoved, Fig. $4-5$ fra Kap Dalton. 


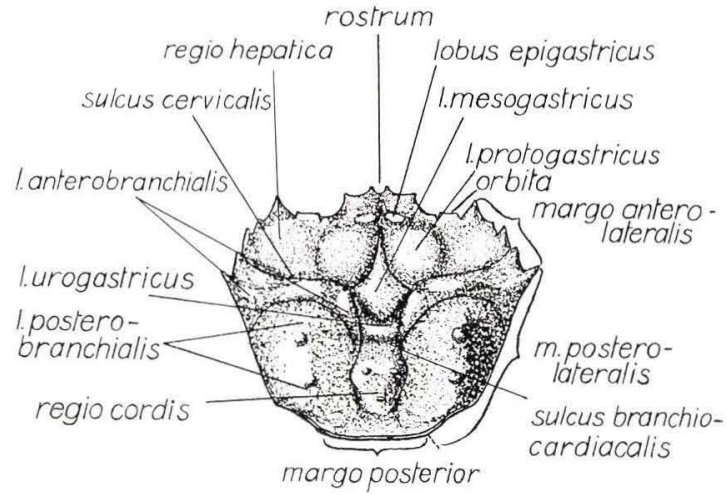

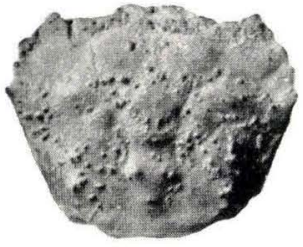

2

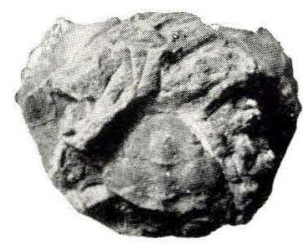

3

Chr. Halkier fot.

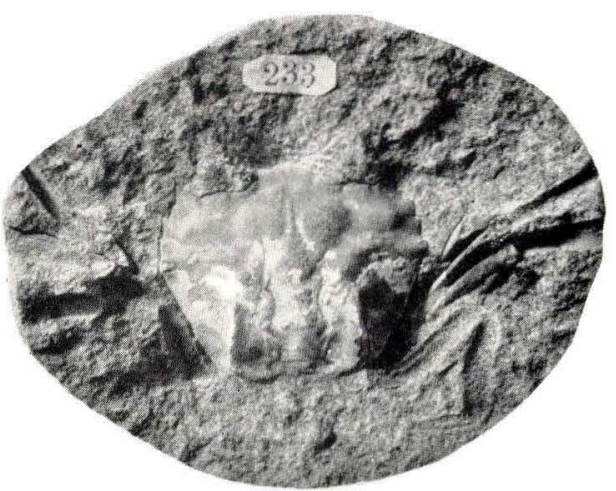

4

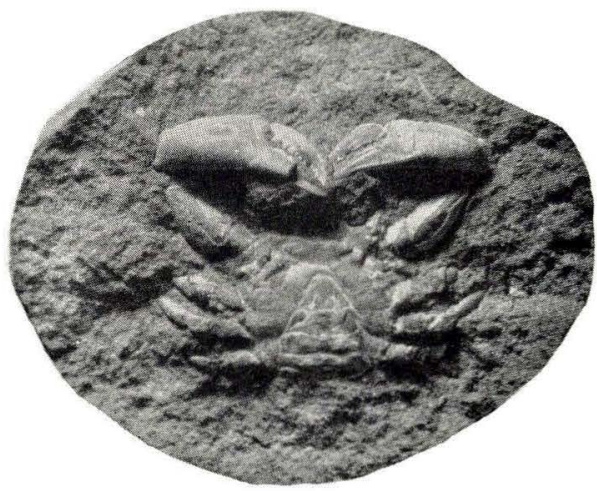

5 
Tavle VIII. 
Fig. 1. Coeloma incarinatum nov. sp.; hanligt Cephalothorax, Dorsalsiden.

" $2 . \quad "$ " " samme Exemplar fra Ventralsiden.

"3. " " " hanligt Sternum (Cephalothorax mangler).

" 4. " bicarinatum Ravs; hanligt Cephalothorax.

"5. " " " samme Exemplar fra Ventralsiden (Original til Ravn 94, Tavle V, Fig. 4).

Fig. $1-3$ fra Klintinghoved, Fig. $4-5$ fra Kap Dalton. 

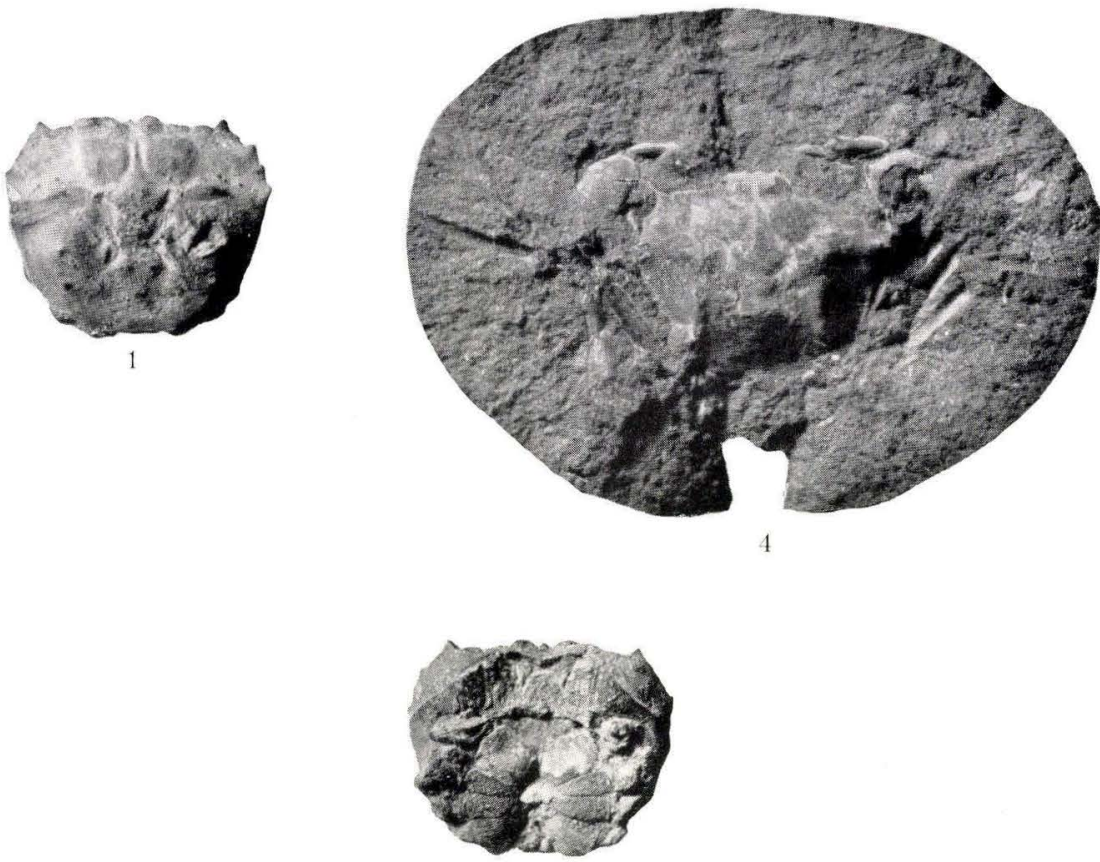

2

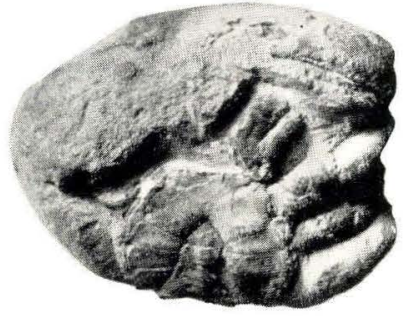

3

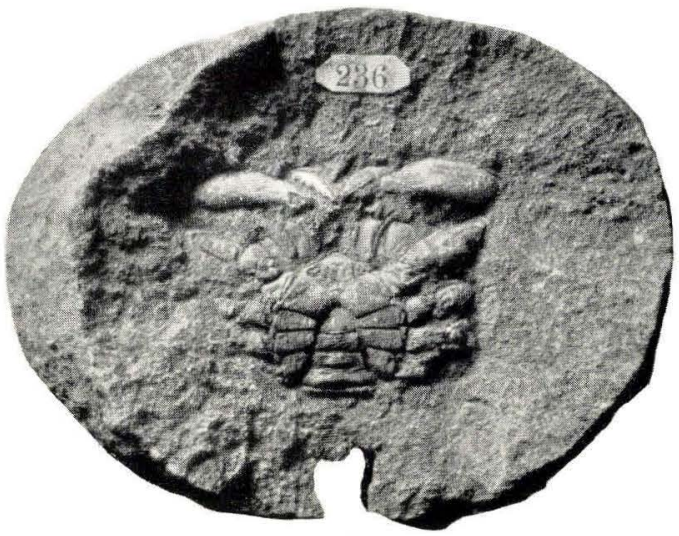

Chr. Halkier fot. 
